\title{
Vendor Testing of Sensitive Compounds in Simulated Dry Sludge
}

by

L. O. Dworjanyn

Westinghouse Savannah River Company

Savannah River Site

Aiken, South Carolina 29808

DOE Contract No. DE-AC09-96SR18500

This paper was prepared in connection with work done under the above contract number with the $U$. S. Department of Energy. By acceptance of this paper, the publisher and/or recipient acknowledges the U.S. Government's right to retain a nonexclusive, royalty-free license in and to any copyright covering this paper, along with the right to reproduce and to authorize others to reproduce all or part of the copyrighted paper. 


\section{DISCLAIMER}

This report was prepared as an account of work sponsored by an agency of the United States Government. Neither the United States Government nor any agency thereof, nor any of their employees, makes any warranty, express or implied, or assumes any legal liability or responsibility for the accuracy, completeness, or usefulness of any information, apparatus, product, or process disclosed, or represents that its use would not infringe privately owned rights. Reference herein to any specific commercial product, process, or service by trade name, trademark, manufacturer, or otherwise does not necessarily constitute or imply its endorsement, recommendation, or favoring by the United States Government or any agency thereof. The views and opinions of authors expressed herein do not necessarily state or reflect those of the United States Government or any agency thereof.

This report has been reproduced directly from the best available copy.

Available to DOE and DOE contractors from the Office of Scientific and Technical Information, P.O. Box 62, Oak Ridge, TN 37831; prices available from (615) 576-8401.

Available to the public from the National Technical Information Service, U.S. Department of Commerce, 5285 Port Royal Road, Springfield, VA 22161. 


\section{DISCLAIMER}

\section{Portions of this document may be illegible}

in electronic image products. Images are produced from the best available original document. 


\title{
Vendor Testing Of Sensitive Compounds In Simulated Dry Sludge
}

\author{
L. O. Dworjanyn \\ Waste Processing Technology Section \\ Savannah River Technology Center \\ Savannah River Site, Bdg. 735-11A
}

\section{SUMMARY}

- Vendor tests at Chilworth Technology confirm Savannah River Technology Center (SRTC) and literature findings that synthetic mercury fulminate is thermally unstable, spontaneously decomposing at $167^{\circ} \mathrm{C}$ to $188^{\circ} \mathrm{C}$. Vendor Differential Scanning Calorimetry (DSC) tests show major exotherms starting at $230^{\circ} \mathrm{C}$, with secondary peaks as high as $245^{\circ} \mathrm{C}$. Only minor peaks were observed at $180^{\circ} \mathrm{C}$. The exact location of the DSC peaks and the number of peaks varies with test sample confinement, sample size, and the heating rate. Bulk mercury fulminate decomposition was clearly evident when heating a 3-g sample in a 35-mL sealed "Carius" tube. An exotherm and pressure buildup were both observed at $184^{\circ} \mathrm{C}$. The decomposition can be observed visually in an open capillary using a melting point apparatus. The fulminate begins to gray at $188^{\circ} \mathrm{C}$ and disappears at about $193{ }^{\circ} \mathrm{C}$, leaving a mercury residue. Literature search shows that mercury fulminate decomposes instantly at $277^{\circ} \mathrm{C}$, or as low as $133^{\circ} \mathrm{C}$ when heated for 12 minutes.

- Blends of mercury fulminate with Tank $15 \mathrm{H}$ simulated dry sludge showed measurable exotherms at 5 and $10 \mathrm{wt} \%$ mercury fulminate, vs. $6 \mathrm{wt} \%$ maximum assumed mercury concentration in High Level Waste (HLW) sludge, indicating thermal decomposition of fulminate in dry sludge blends. The initial decomposition exotherm temperature was reduced to about $182^{\circ} \mathrm{C}$ for blends with caustic sludge, indicating a possible solid phase reaction with the sludge. SRTC measurements have shown that the total heat generated by the fulminate was always less than the natural endotherms in the caustic sludge.

- The interaction between $10 \mathrm{wt} \%$ mercury fulminate and caustic sludge becomes more apparent in 10-g sample decomposition in a sealed "Carius" tube, when a major exotherm peak is observed at $123^{\circ} \mathrm{C}$. In neutral sludge only minor exotherms were observed at $125^{\circ} \mathrm{C}$, and 3-g "Carius" tube samples showed no exotherms. Although the major $123^{\circ} \mathrm{C}$ exotherm with caustic sludge was observed on a single test run, the interaction in the presence of caustic sludge is also evidenced by a two thirds reduction in gas generation, including the 3-g sample. Reduction in off gas formation implies a decomposition process in which the mercury fulminate is being destroyed, rather than an initiation process igniting the fulminate at a lower temperature. 
- Impact sensitivity of mercury fulminate was quantified by the Vendor using ASTM Standards procedure E680. Positive results were observed at a drop height of $125 \mathrm{~cm}$, and negative at $80 \mathrm{~cm}$, based on sample residue discoloration. DCS scans on test residue confirmed that residual fulminate was greatly reduced after positive tests, and the peak temperature was reduced in all cases. Microscopic examination of impact residue at SRTC showed that the low impact residue had some black spots, presumably mercury, and the high impact residue had some white areas, indicating incomplete decomposition.

- Impact testing on dry sludge containing 5 and $10 \mathrm{wt} \%$ mercury fulminate was negative on all tests at the maximum height of $270 \mathrm{~cm}$, based on no visible change in the test residue. By ASTM definition a positive reaction is defined as an impact that produces one or more of the following: (a) audible report, (b) flame or visible light, (c) definite evidence of smoke (not dust), (d) definite evidence of discoloration of the sample due to decomposition. If doubt exists, specify the trial as non-reaction. The last point implies, by definition, that even if some mercury fulminate decomposes to mercury the test is considered negative (i.e. no reaction).

- SRTC impact testing using a smaller impact area and a deeper sample resulted in total decomposition of pure mercury fulminate, leaving only mercury droplets as a residue. Impact testing of 5 and $15 \mathrm{wt} \%$ mercury fulminate (and oxalate) in dry sludge also produced no positive reaction at the maximum drop height.

- Microscopic examination of SRTC fulminate (and oxalate) in sludge impact residues showed an amalgam-like residue possibly containing mercury from fulminate decomposition. Since the impact test relies primarily on residue discoloration, fulminate in "white" sludge may have shown a positive reaction.

\section{CONCLUSIONS}

- DSC measurements provide a practical tool for detecting energetic compounds in real HLW sludge.

- Impact hammer testing (and friction testing) is unlikely to produce detectable results at energetic compound concentrations below $10 \mathrm{wt} \%$ in dry HLW sludge.

\section{RECOMMENDATIONS}

- Demonstrate that sensitive mercury or silver compounds cannot exist under simulated dry sludge conditions using DSC and other appropriate supporting tools. Confirm safety in larger scale tests such as 10-g "Carius" tube.

- If residual sensitive compounds are retained in the sludge, conduct ignition propagation tests. Fulminate decomposition may not be able to propagate even when initiated by flame, spark, or detonation, due to dilution effect and sludge heat capacity. For example, highly sensitive trinitro glycerine is stabilised with inert diatomaceous earth to form non-flammable dynamite. 


\section{CONTENTS}

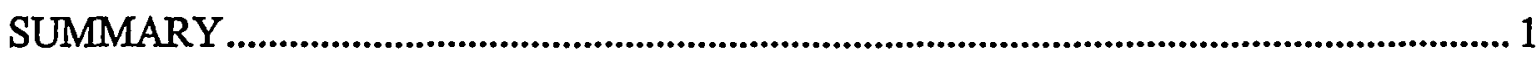

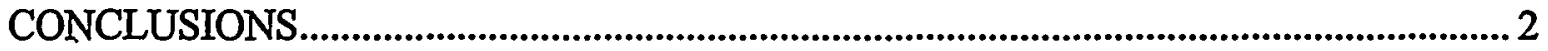

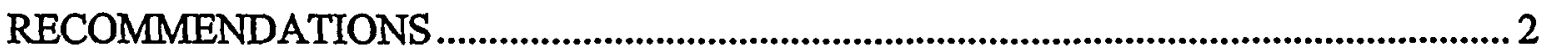

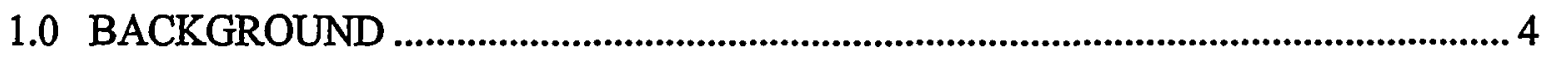

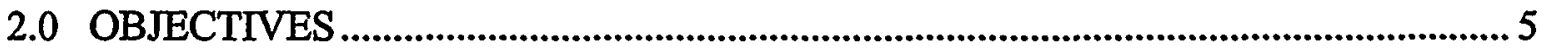

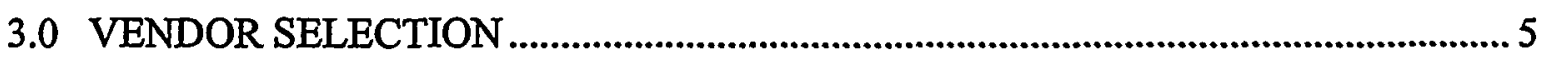

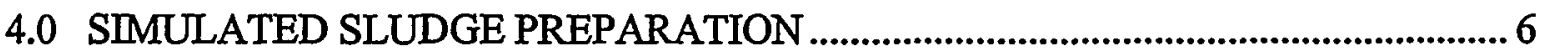

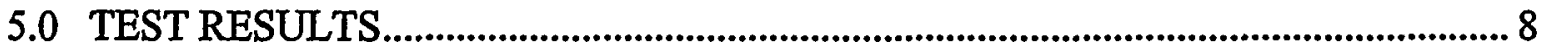

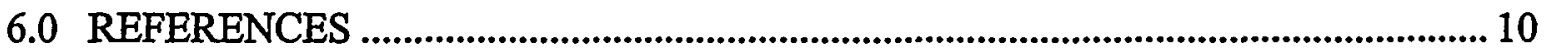

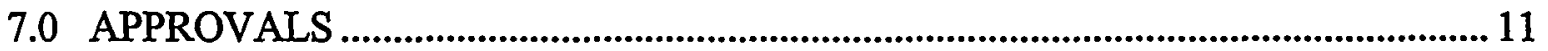

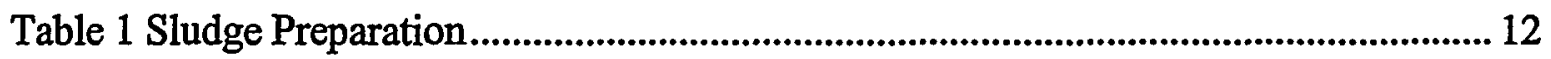

Table 2 Sludge Elements ....................................................................................................... 13

Table 3 Solution Composition .................................................................................................. 14

Table 4 Sludge Insolubles........................................................................................................ 15

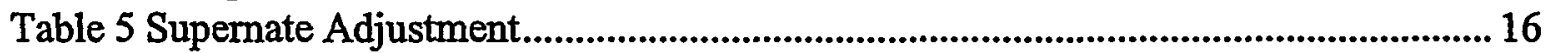

Table 6 Mercury Fulminate Decomposition Temperature Reconciliation ............................. 17

Table 7 Mercury Fulminate Decomposition in Dry Sludge.................................................... 18

Figure 1 Caustic Sludge Drying in a Beaker ........................................................................ 19

Figure 2 Salt Deposits on Beaker Wall, above Slurry Level ................................................. 20

Figure 3 Neutral Sludge Drying in a Beaker.............................................................................. 21

Figure 4 Neutral Nitrate Salt Deposits on Beaker Wall......................................................... 22

Figure 5 Vendor Caustic Sludge Aging on Glass Slide........................................................ 23

Figure 6 Layers of Ground Dry Sludge before Mixing ............................................................... 24

Figure 7 Mercury Fulminate Impact Residue - NO GO....................................................2 25

Figure 8 Mercury Fulminate Impact Residue - Reacted (GO) ............................................. 26

Figure 9 DSC of Mercury Fulminate Hammer Test Residue .................................................... 27

Figure 10 Mercury Fulminate Decomposition Induction Time............................................ 28

Appendix A "Dry Sludge Safety Characterization", Vendor Proposal Request. ..............29

Appendix B "Caustic Simulated Sludge Preparation", WPT Procedure..............................33

Appendix C "Mercury Fulminate Preparation Procedure", For Vendor Information.......37

Appendix D "Southwest Research Institute Proposal for Dry Sludge Testing".................39

Appendix E "Chilworth Technology Proposal for Dry Sludge Testing"............................51

Appendix F "ASTM E680 Impact Hammer Tester", as used by Chilworth Technology 57

Appendix G "Sludge Vendor Testing - Scope of Work, Rev. 1" for Chilworth Tech. ....65

Appendix H 'Mercury Fulminate (In Pure and Dry Sludge) Impact Sensitivity and

Calorimetry Screening", Vendor Final Report

Vendor Report Appendix 1 "Drop Weight Impact Sensitivity Tester"

Vendor Report Appendix 2 See Main Report Appendix C and Appendix F

Vendor Report Appendix 3 DSC Calibration 
Vendor Report Appendix 4

Vendor Report Appendix 5

Vendor Report Appendix 6

Vendor Report Appendix 7
DSC Thermograms

"Carius Tube Results"

"BAM" Fallhammer Test Apparatus

Raw Data
L. O. Dworjanyn

WSRC-RP-99-00428, Rev. 0

Page 6 of 67

\subsection{SIMULATED SLUDGE PREPARATION}

\section{Basis}

Sludge is insoluble residue from various canyon operations, including fuel rod dissolution, solvent extraction and other opeartions. This acidic residue is neutralized and additional caustic added to allow storage in carbon steel tanks. The bulk of the supernate is decanted, concentrated by evaporation and stored as soluble salt. The salt is redissolved, decontaminated and ultimately converted to Saltstone. The insoluble sludge residue is usually washed to remove excess soluble salts and aluminum and processed to glass.

A process based simulation of sludge would be impractical and not very meaningful due to the many sources of sludge. Instead, soluble chemicals can be combined so that precipitates form in composition similar to sludge tank analyses. Next, the precipitated solids can be suspended in known tank sludge soluble salts composition to create a realistic simulant for tank sludge. The resultant simulated sludge should match real waste tank composition in the following parameters:

1. Insoluble solids composition.

2. Solution composition.

3. Solids concentration in the solution.

\section{Insoluble Solids Prepatation}

The insoluble solids were prepared using Mark Barnes' formulation (Appendix B, Ref. 3). In this procedure various components are sequentially added to caustic solution to effect the precipitation, as detailed in the Appendix. The resultant suspension is easy to agitate with a magnetic stirrer. On standing for 48 hours at room temperature the sludge settled from $2,200 \mathrm{~mL}$ to $1,200 \mathrm{~mL}$, leaving a clear supernate. Final prepared composition is summarized in Table 1, and the composition listed by element is shown in Table 2.

The decanted solution and dry washed insoluble solids were submitted for elemental analyses as shown in Table 3 . As expected, the solution was mostly soluble sodium and potassium with a trace of aluminum. Potassium was not actually analysed, but assumed to be all in solution since no insoluble compounds were present. The bulk of insoluble solids are in the form of aluminum, as shown in Table 4. The concentration of insoluble solids can be estimated by subtracting elements in solution from elements added in the solution makeup, as shown in Table 4. The calculated values were consistent with analytical results for the dry insoluble solids. 


\subsection{OB.JECTIVES}

1. Identify experienced vendors and obtain feed back on appropriate testing to resolve the dry sludge issues.

2. Select a vendor and contract to perform independent testing with mercury fulminate in simulated dry sludge.

3. Test the explosive behavior of mercury fulminate in larger dry sludge larger samples, up to $10 \mathrm{~g}$.

\subsection{VENDOR SELECTION}

Five vendors were contacted, based on previous SRTC experience and internet search, per example in Appendix A:

1. Dr. Walt Gray, Southwest Research Institute, 6220 Culebra Road, San Antonio, TX 78228, Tel. (210) 522-5128

2. Dr. Vahid Ebadad, Chilworth Technology, Inc. 11 Deer Park Drive, Suite 204, Monmouth Junction, NJ 08852-9623,

Tel. (732) 274-0900

3. Dr. Doug Olson, Research Center for Energetic Materials, New Mexico Tech, 801 Leroy Place, Socorro, NM 87801, Tel. (505) 835-5733 (Appendix A).

4. Mr. Ali Reza, Failure Analysis Associates, 149 Commonwealth Drive, Menlo Park, CA 94025

Tel. (415) 688-7284

Southwest Research Institute is a private, industry supported research facility providing support to scientific and engineering community for over 50 years. They conduct research in Fuels and Lubricants, Electronic Technology, Materials Research, Space Sciences, Fluid Dynamics, Encapsulation and others areas. They specialize particularly in Fire Technology including explosives and safety hazards. They are well equipped for conducting small scale experiments and larger explosive tests as detailed in Appendix D. Of particular relevance is their technique for evaluating flame or explosive propagation (Appendix D, Figure 5). This larger scale test could show that even if mercury fulminate were present at 5 to $10 \mathrm{wt} \%$ in dry sludge, and decomposition was initiated thermally or by detonation, propagation may not proceed at available concentration. During the contract bidding process SWI had to excuse themselves due to an on-going oversight contract with the government.

Chilworth Technology provide consulting and testing services in fire protection, vapor explosives and solid explosives. Their proposal is shown in Appendix E.

A timely response from the other vendors was not received to allow inclusion in the bid process. 


\subsection{SIMULATED SLUDGE PREPARATION}

Basis

Sludge is insoluble residue from various canyon operations, including fuel rod dissolution, solvent extraction and other opeartions. This acidic residue is neutralized and additional caustic added to allow storage in carbon steel tanks. The bulk of the supernate is decanted, concentrated by evaporation and stored as soluble salt. The salt is redissolved, decontaminated and ultimately converted to Saltstone. The insoluble sludge residue is usually washed to remove excess soluble salts and aluminum and processed to glass.

A process based simulation of sludge would be impractical and not very meaningful due to the many sources of sludge. Instead, soluble chemicals can be combined so that precipitates form in composition similar to sludge tank analyses. Next, the precipitated solids can be suspended in known tank sludge soluble salts composition to create a realistic simulant for tank sludge. The resultant simulated sludge should match real waste tank composition in the following parameters:

1. Insoluble solids composition.

2. Solution composition.

3. Solids concentration in the solution.

\section{Insoluble Solids Prepatation}

The insoluble solids were prepared using Mark Barnes' formulation (Appendix B, Ref. 3). In this procedure various components are sequentially added to caustic solution to effect the precipitation, as detailed in the Appendix. The resultant suspension is easy to agitate with a magnetic stirrer. On standing for $\mathbf{4 8}$ hours at room temperature the sludge settled from $2,200 \mathrm{~mL}$ to $1,200 \mathrm{~mL}$, leaving a clear supernate. Final prepared composition is summarized in Table 1, and the composition listed by element is shown in Table 2.

The decanted solution and dry washed insoluble solids were submitted for elemental analyses as shown in Table 3 . As expected, the solution was mostly soluble sodium and potassium with a trace of aluminum. Potassium was not actually analysed, but assumed to be all in solution since no insoluble compounds were present. The bulk of insoluble solids are in the form of aluminum, as shown in Table 4 . The concentration of insoluble solids can be estimated by subtracting elements in solution from elements added in the solution makeup, as shown in Table 4. The calculated values were consistent with analytical results for the dry insoluble solids.

\section{Sludge Soluble Salts Composition Adjustment}

The goal solution composition is shown in Table 5 per D. D. Walker Tank 15 analyses (Ref. 10). 
The prepared slurry can be filtered or decanted and washed to separate the solids. The solids can be dispersed in prepared supernate to form the final simulant (Ref. 4). Alternatively, the soluble composition of the prepared slurry can be adjusted by dilution and made-up so that the final dry slurry has the desired composition specified by Walker. This was done for the vendor slurry (Table 5).

\section{Sludge Neutralization}

Mercury fulminate was considered unstable under alkaline conditions. To assure sensitivity of added fulminate during testing, a neutral sludge was prepared by neutralizing the caustic sludge with concentrated nitric acid to $\mathrm{pH} 7$, per DWPF SRAT procedure (Ref . 5).

\section{Sludge Drying}

There were two objectives in preparing dry sludge for vendor testing:

1. Prepare a fine uniform dry caustic sludge to permit dry blending with mercury fulminate so as to retain composition in $\mathrm{mg}$ quantities. This would allow preblending and the use of $3 \mathrm{mg}$ aliquots for Differential Scanning Calorimetry (DSC) testing.

2. Prepare a neutral sludge slurry blend with mercury fulminate and dry together to preserve monolithic dry structure for testing. By neutralizing the sludge, mercury fulminate should retain its sensitivity permitting simulation of in-tank conditions.

When drying the sludge, typically for one to two days at $90^{\circ} \mathrm{C}$, it became apparent that the sludge dries very non uniformly. The insolubles settle to the bottom as expected but the salt migrates up the walls of the beaker and even down the outside of the beaker as shown in Figure 1. The caustic solution wicks up the wall as it dries, segregating from the bulk of the slurry, forming heavy salt deposits on the walls, well above initial slurry level (Figure 2). The same happens with neutralized sludge (Figure 3), although the salt deposits are more fibrous probably because of high nitrate content (Figure 4). Clearly, a monolithic and uniform dry structure is unlikely in the waste tanks. In fact, the dry structure can change under ambient atmospheric conditions. This is illustrated in Figure 5 where the edge of a sample cube of brown dry sludge is shown in the top left corner of the picture. After about one month on the microscope slide, the hygroscopic salt has migrated from the sludge to the glass slide forming rings of crystalline salts. Similar re-crystallization activity is observed on retain sludge samples in open beakers. Video observations of dry sludge tanks do not show any noticeable segregation of components and the nature of dry sludge structure is not known.

To assure uniformity for vendor testing all dry samples were ground fine in a mortar and later blended to preserve overall insolubles / salts composition (Figure 6). 


\subsection{TEST RESULTS}

\section{Vendor test results are detailed in Appendix $\mathrm{H}$.}

\section{Mercury Fulminate Decomposition Temperature Reconciliation.}

Literature search suggests that mercury fulminate decomposes thermally at $160^{\circ} \mathrm{C}$ : ("Knallquecksilber verpufft auf $160^{\circ} \mathrm{C}$ ", Ref. 7) during fast heating and at $155^{\circ} \mathrm{C}$ during slower heating. SRTC DSC measurements have shown major exotherms at $167^{\circ} \mathrm{C}$ to $176^{\circ} \mathrm{C}$ vs. $230^{\circ} \mathrm{C}$ to $245^{\circ} \mathrm{C}$ as measured by vendor DSC (Table 6). The vendor found that sample containment plays an important part in peak location and the number of peaks. Part of the variability may be due to mercury re-condensation. This would be influenced by sample containment. Literature search (Ref. 7) shows that the decomposition temperature is a function of heating rate and sample size as shown in Table 6. Mercury fulminate decomposition temperature can be as low as $133^{\circ} \mathrm{C}$ vrhen heated for $12 \mathrm{~min}$. The decomposition induction time decreases with increasing temperature up to $277^{\circ} \mathrm{C}$ when the fulminate explodes instantly (Figure 10). Specific DSC results depend also on instrument sensitivity, cup containment and heat transfer between the cup and the measuring thermocouples. The measured heat of decomposition can double using a more sensitive instrument as illustrated by Fernando Fondeur 5/21/1999 data using a new DSC instrument (Table 6).

Visual observation in a heated open capillary melting point apparatus confirm that fulminate fully decomposes by $188^{\circ} \mathrm{C}$.

\section{Fulminate in Dry Sludge Decomposition.}

Vendor DSC measurements of mercury fulminate in dry sludge show $182{ }^{\circ} \mathrm{C}$ peak exotherm temperature, consistent with SRTC findings (Table 7 and Ref.2). Also, the heat of decomposition, 71 to $87 \mathrm{cal} / \mathrm{g}$, is consistent. Much of the variability is due to base shift in presence of sludge endotherms, as well as DSC instrument characteristics and sample containment.

However, the decrease in Vendor DSC peak exotherm temperature from $230^{\circ} \mathrm{C}$ for pure fulminate to $182^{\circ} \mathrm{C}$ in blends with sludge requires explanation. It is hard to see how a reduced quantity and a dispersed mercury fulminate phase would decompose at a lower temperature compared to a pure phase, given the same instrumentation and fulminate chemistry. This indicates some interaction between the mercury fulminate and the dry caustic sludge.

The interaction between mercury fulminate and caustic sludge becomes more apparent in $10 \mathrm{~g}$ sample decomposition in a sealed "Carius" tube (Table 7), when a major exotherm peak was observed at $123^{\circ} \mathrm{C}$. In neutral sludge only minor exotherms were observed at $125^{\circ} \mathrm{C}$, and $3 \mathrm{~g}$ "Carius" tube samples showed no exotherms. Although the major $123^{\circ} \mathrm{C}$ 
exotherm with caustic sludge was observed on a single test run, the interaction in the presence of caustic sludge is also evidenced by

(1) reduced total tube pressure, as compared to pure fulminate and neutral sludge (Table 7),

(2) two thirds reduction in gas generation, including the $3 \mathrm{~g}$ runs.

(3) Vendor DSC exotherm reduction.

Reduction in off gas formation implies a decomposition process in which the mercury fulminate is being destroyed, rather than an initiation process igniting the fulminate at a lower temperature. This is consistent with aging of fulminate and other explosives, particularly at elevated temperatures. Literature search shows that mercury fulminate is reactive (Ref. 7) and deteriorates with storage (Ref. 8), resulting in 10\% loss in purity after 12 months at $50^{\circ} \mathrm{C}$, or 2 days at $80^{\circ} \mathrm{C}$. This effect would be more pronounced in the slower heating Carius tube, as compared to DSC measurements.

\section{Fall Hammer Impact Testing}

Impact sensitivity of mercury fulminate was quantified by the Vendor using ASTM Standards procedure E680. This procedure, Appendix F, uses a wider impact area and a thinner sample, compared to SRTC procedure. The sample loading was $40 \mathrm{~mm}^{3}$, typically 39 to $41 \mathrm{mg}$ distributed over $0.5 \mathrm{in}$. impact area, or $0.315 \mathrm{mg} / \mathrm{mm}^{2}$, equivalent to $0.315 \mathrm{~mm}$ sample thickness. SRTC loading was $20 \mathrm{mg}$ in a $3 / 16$ in. cup, or $1.12 \mathrm{mg} / \mathrm{mm}^{2}$.

Positive mercury fulminate results were observed at a drop height of $125 \mathrm{~cm}$, and negative at $80 \mathrm{~cm}$, based on sample residue discoloration. DCS scans on test residue confirmed that residual fulminate was greatly reduced after positive tests, and the peak temperature was reduced in all cases (Figure 9). Microscopic examination of impact residue at SRTC showed that the low impact residue had some black spots (Figure 7), presumably mercury, and the high impact residue had some white areas (Figure 8), indicating incomplete decomposition.

Impact testing on dry sludge containing 5 and $10 \mathrm{wt} \%$ mercury fulminate was negative on all tests at the maximum height of $270 \mathrm{~cm}$, based on no visible change in the test residue. By ASTM definition a positive reaction is defined as an impact that produces one or more of the following:

(a) audible report,

(b) flame or visible light

(c) definite evidence of smoke (not dust)

(d) definite evidence of discoloration of the sample due to decomposition. If doubt exists, specify the trial as non-reaction.

The last point implies, by definition, that even if some mercury fulminate decomposes to mercury the test is considered negative (i.e. no reaction). This methodology fails to answer a key question: Is mercury fulminate in dry sludge decomposed by impacting, or if the sludge were white could the impact produce positive results? This is an important tank safety consideration since a small and dispersed fulminate phase may well be stable to impact and to flame propagation, even though DSC would show thermal decomposition. 


\subsection{REFERENCES}

1. S. D. Fink, "Energetic Compounds \& Dry Sludge: Overview of Experimental Program", SRT-LWP-08-0094, 9/30/1998

2. M. J. Barnes, L. O. Dworjanyn, S. D. Fink, F. F. Fondeur, M. W. Geeting, M. S. Hay, R. F. Swingle, W. R. Wilmarth, "Examination of the Potential for Formation of Energetic Compounds in Dry Sludge", WSRC-TR-98-0047, 11/2/1998

3. M. J. Barnes, WSRC-NB-98-00161, pp. 5 \& 9.

4. M. J. Barnes, WSRC-NB-98-00161, pp. 22-23.

5. E. W. Holtzscheiter, "Tank Technical Request FLW/DWPF/TTR-970139", WSRCRP-98-00329, 6/5/1998.

6. W. R. Wilmarth, "Mercury Fulminate and Mercury Oxalate Synthesis and Associated Sludge Testing", I-WPT-001, 8/27/1998.

7. "Gmelins Handbuch der Anorganischen Chemie", 8 Auflage, Quecksilber, Teil B Lieferung 3, pp 1229 - 1247.

8. Kirk-Othmer, "Encyclopaedia of Chemical Technology", Explosives Section, $2^{\text {nd }}$ Edition, Volume 8, p 589. 1995.

9. J. R. Fowler, "Sludge Composition for Each Tank and DWPF Feed Batches", DPST84-556, 6/11/1984.

10. D. D. Walker, "Tank 15 Salt Solution", Laboratory Notebook DPSTN-4385, page 10, 9/12/1983. 
L. O. Dworjanyn

WSRC-RP-99-00428, Rev. 0

Page 11 of 67

7.0 APPROVALS

AUTHOR

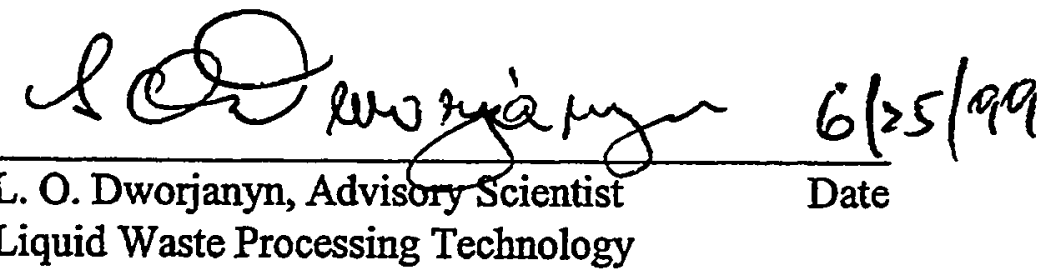

DESIGN CHECK

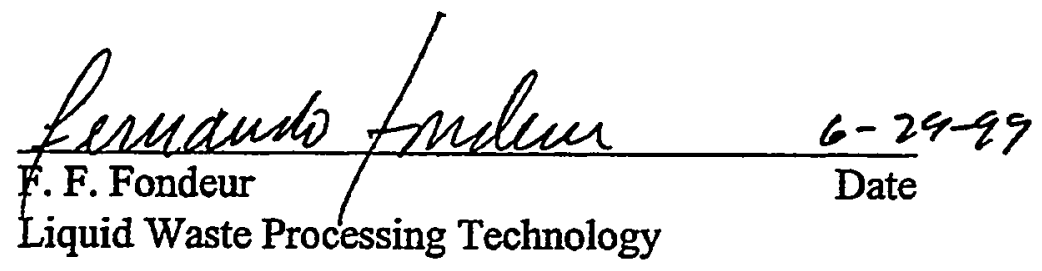

MANAGEMENT

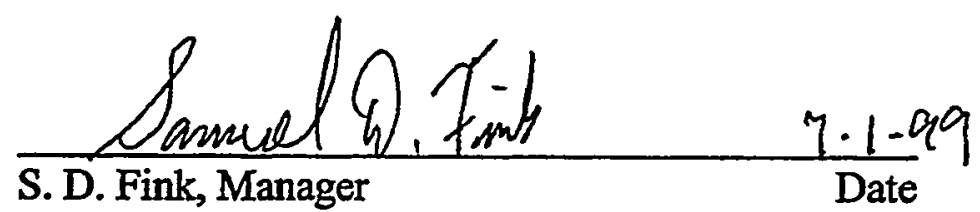

Liquid Waste Processing Technology

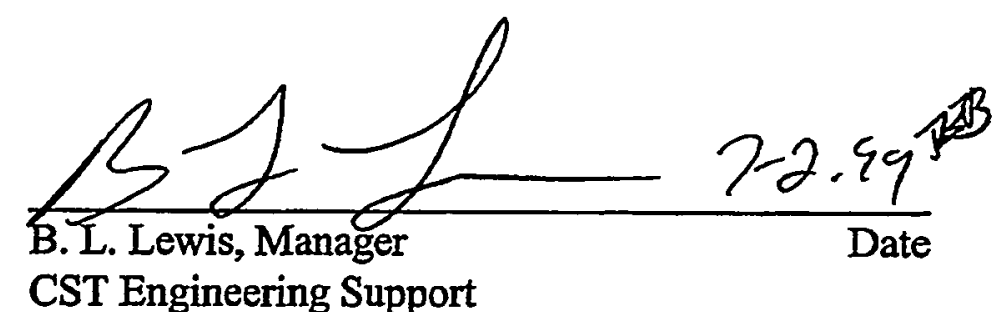

CST Engineering Support

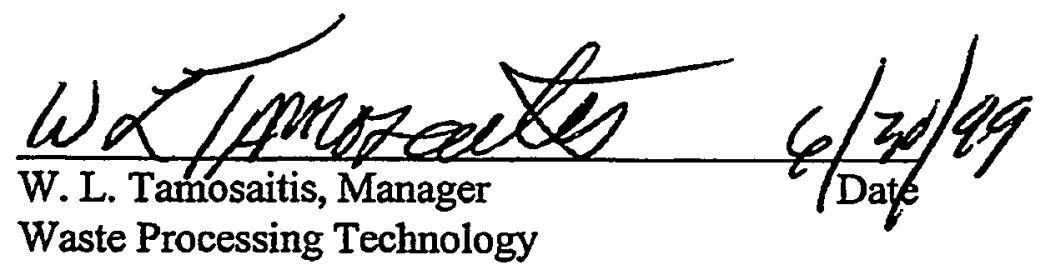




\section{Table 1 Sludge Preparation}

\begin{tabular}{|c|c|c|c|c|c|c|c|c|c|c|c|}
\hline \multicolumn{12}{|c|}{ D:lapplSUudgelRP428IIRP428Tables.xls]Table Table1 } \\
\hline Chemical & Mol. Wt. & Dilutn & Require & Used & 日. & MMt & W Elem & $\mathrm{NO}_{3}^{-}$ & & $\mathrm{OH}$ & $\mathrm{H}_{2} \mathrm{O}$ \\
\hline q Additive & $(g /$ mole $)$ & Factor & Mass $(g)$ & g-Mol & & & g & $\mathbf{g}$ & $\mathbf{g}$ & & g \\
\hline $1 \mathrm{Fe}\left(\mathrm{NO}_{3}\right)_{3} \mathrm{O} \mathrm{H}_{2} \mathrm{O}$ & 404.02 & 1 & 70.89 & 0.1755 & $5 \mathrm{Fe}$ & 55.85 & 9.799 & 3264 & & & 28.45 \\
\hline $2 \mathrm{Al}\left(\mathrm{NO}_{3}\right)_{3} \mathrm{O}_{2} \mathrm{H}_{2} \mathrm{O}$ & 375.13 & 1 & 856.40 & 2.2829 & $9 \mathrm{Al}$ & 26.98 & 61.597 & 424.66 & & & 370.15 \\
\hline $3 \mathrm{KMnO}_{4}$ & 158.04 & 1 & 5.75 & 0.0364 & & 39.10 & 1.423 & & & & 1.31 \\
\hline 4 & & & & & $\mathrm{Mn}$ & 54.94 & 1.999 & & & & \\
\hline $5 \mathrm{Mn}\left(\mathrm{NO}_{3}\right)_{2} ; 50.3 \%$ & 178.95 & 0.503 & 19.43 & 0.0546 & $6 \mathrm{Mn}$ & 54.94 & 3.000 & 6.77 & & & 9.66 \\
\hline $6 \mathrm{Ca}\left(\mathrm{NO}_{3}\right)_{2} \mathrm{O}_{4} \mathrm{H}_{2} \mathrm{O}$ & 236.15 & 1 & 2.48 & 0.0105 & $5 \mathrm{Ca}$ & 40.08 & 0.421 & 1.30 & & & 0.76 \\
\hline $7 \mathrm{Mg}\left(\mathrm{NO}_{3}\right)_{2} \mathrm{O}_{6} \mathrm{H}_{2} \mathrm{O}$ & 256.41 & 1 & 3.16 & 0.0123 & $3 \mathrm{Mg}$ & 24.31 & 0.300 & 1.53 & & & 1.33 \\
\hline $8 \mathrm{Na}_{2} \mathrm{SiO}_{3} \mathrm{O}_{2} \mathrm{H}_{2} \mathrm{O}$ & 284.20 & 1 & 3.84 & 0.0135 & $5 \mathrm{Na}$ & 22.99 & 0.311 & & & & 2.19 \\
\hline 9 & & & & & $\mathrm{Si}$ & 28.09 & 0.379 & & & & \\
\hline $10 \mathrm{Ni}\left(\mathrm{NO}_{3}\right)_{2} \mathrm{O}_{2} \mathrm{H}_{2} \mathrm{O}$ & 290.81 & 1 & 4.56 & 0.0157 & $7 \mathrm{Ni}$ & 58.70 & 0.920 & 1.94 & & & 1.69 \\
\hline $\left.11 \mathrm{Cu}\left(\mathrm{NO}_{3}\right)_{2}\right)_{2.5 \mathrm{H}_{2} \mathrm{O}}$ & 23259 & 1 & 0.37 & 0.0016 & $6 \mathrm{Cu}$ & 63.55 & 0.100 & 0.20 & & & 0.07 \\
\hline $12 \mathrm{Cr}\left(\mathrm{NO}_{3}\right)_{3} \mathrm{O}_{2} \mathrm{H}_{2} \mathrm{O}$ & 400.15 & 1 & 0.31 & 0.0008 & $8 \mathrm{Cr}$ & 52.00 & 0.040 & 0.14 & & & 0.12 \\
\hline $13 \mathrm{RuCl}_{3} ; 41.74 \%$ & 207.43 & 0.417 & 0.31 & 0.0006 & $6 \mathrm{Ru}$ & 101.07 & 0.062 & & 0.08 & & \\
\hline $14 \mathrm{TiO}_{2}$ & 79.90 & 1 & 0.07 & 0.0008 & $8 \pi$ & 47.90 & 0.040 & & & & \\
\hline $15 \mathrm{Rh}\left(\mathrm{NO}_{3}\right)_{2} ; .4 .93 \%$ & 226.91 & 0.049 & 0.53 & 0.0001 & $1 \mathrm{Rh}$ & 102.91 & 0.012 & 0.01 & & & \\
\hline $16 \mathrm{Pd}\left(\mathrm{NO}_{3}\right) ; 15.27 \%$ & 230.41 & 0.153 & 0.03 & 0.0000 & $0 \mathrm{Pd}$ & 106.40 & 0.002 & 0.00 & . & & \\
\hline $17 \mathrm{Ba}\left(\mathrm{NO}_{3}\right)_{2}$ Nitrobirite & 261.35 & 1 & 0.31 & 0.0012 & $2 \mathrm{Ba}$ & 137.34 & 0.165 & 0.15 & & & \\
\hline $18 \mathrm{Zn}\left(\mathrm{NO}_{3}\right)_{2} \mathrm{O}^{6} \mathrm{H}_{2} \mathrm{O}$ & 297.47 & 1 & 0.37 & 0.0012 & $2 \mathrm{Zn}$ & 65.38 & 0.080 & 0.15 & & & 0.13 \\
\hline $19 \mathrm{Sr}\left(\mathrm{NO}_{3}\right)_{2}$ & 211.65 & 1 & 0.17 & 0.0008 & $8 \mathrm{Sr}$ & 87.62 & 0.071 & 0.10 & & & \\
\hline $0 \mathrm{Na}_{2} \mathrm{~B}_{4} \mathrm{O}_{7} \mathrm{O1OH}_{2} \mathrm{O}$ & 381.37 & 1 & 0.18 & 0.0005 & $5 \mathrm{~B}$ & 10.81 & 0.005 & & & & 0.11 \\
\hline & & & & & $\mathrm{Na}$ & 22.99 & 0.011 & & & & \\
\hline $\mathrm{NaC}$ & 40.00 & 1 & 350.00 & 8.7506 & $6 \mathrm{Na}$ & 22.99 & 1.175 & & & 48.82 & \\
\hline & & & & & & & & & & & \\
\hline TOTALC & & & 1316.40 & & & 900.42 & 81.91 & 9.60 & 0.08 & 148.8 & 98 \\
\hline
\end{tabular}




\section{Table 2 Sludge Elements}

\section{D:lapplSidgelRP428\[RP428Tables.x|s]Table Table2}

\begin{tabular}{|c|c|c|c|c|c|c|c|c|c|c|c|}
\hline & & & & & & & MMt: & 62005 & 35.453 & 317.007 & 18.015 \\
\hline Chemical & Mol. Wt. & Dilut & Require & Used & 日. & Mut & WtEem & $\mathrm{NO}_{3}^{-}$ & $\mathrm{Cr}$ & OH & $\mathrm{H}_{2} \mathrm{O}$ \\
\hline Seq Additive & (g/mole) & Factor & $\operatorname{Mass}(\mathrm{g})$ & $\mathrm{g}-\mathrm{Mol}$ & & & $g$ & g & g & $\mathbf{g}$ & \\
\hline $2 \mathrm{Av}\left(\mathrm{NO}_{3}\right)_{3} \mathrm{OPH}_{2} \mathrm{O}$ & 375.13 & 1 & 856.40 & 2.2829 & & 26.98 & 61.597 & 424.66 & & & 370.15 \\
\hline 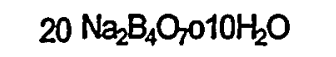 & 381.37 & 1 & 0.18 & 0.0005 & & 10.81 & 0.005 & & & & 0.11 \\
\hline $17 \mathrm{Ba}\left(\mathrm{NO}_{3}\right)_{2}$ Nitroborat & 261.35 & 1 & 0.31 & 0.0012 & $\mathrm{Ba}$ & 137.34 & 0.165 & 0.15 & & & \\
\hline $6 \mathrm{Ca}\left(\mathrm{NO}_{3}\right)_{2} \mathrm{O}_{4} \mathrm{H}_{2} \mathrm{O}$ & 236.15 & 1 & 2.48 & 0.0105 & $5 \mathrm{Ca}$ & 40.08 & 0.421 & 1.30 & & & 0.76 \\
\hline & & & & & $\begin{array}{l}\mathrm{Cd} \\
\mathrm{Co}\end{array}$ & & & & & & \\
\hline $12 \mathrm{Cr}\left(\mathrm{NO}_{3}\right)_{3} \mathrm{O} \mathrm{H}_{2} \mathrm{O}$ & 400.15 & 1 & 0.31 & 0.0008 & $\mathrm{Cr}$ & 5200 & 0.040 & 0.14 & & & 0.12 \\
\hline 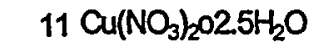 & 232.59 & 1 & 0.37 & 0.0016 & $\mathrm{Cu}$ & 63.55 & 0.100 & 0.20 & & & 0.07 \\
\hline $1 \mathrm{Fe}\left(\mathrm{NO}_{3}\right)_{3} \mathrm{OSH}_{2} \mathrm{O}$ & 404.02 & 1 & 70.89 & 0.1755 & $\mathrm{Fe}$ & 55.85 & 9.799 & 32.64 & & & 28.45 \\
\hline $3 \mathrm{KMnO}_{4}$ & 158.04 & 1 & 5.75 & 0.0364 & $K$ & 39.10 & 1.423 & & & & 1.31 \\
\hline & & & & & $\mathrm{La}$ & & & & & & \\
\hline $7 \mathrm{Mg}\left(\mathrm{NO}_{3}\right)_{2} \mathrm{O}_{6} \mathrm{H}_{2} \mathrm{O}$ & 256.41 & 1 & 3.16 & 0.0123 & $\mathrm{Mg}$ & 24.31 & 0.300 & 1.53 & & & 1.33 \\
\hline $5 \mathrm{Mn}\left(\mathrm{NO}_{3}\right) ; 50.3 \%$ & 178.95 & 0.503 & 19.43 & 0.0546 & $\mathbf{M n}$ & 54.94 & 4.999 & 6.77 & & & 9.66 \\
\hline & & & & & Mo & & & & & & \\
\hline $22 \mathrm{NaOH}$ & 40.00 & 1 & 350.00 & 8.7506 & $\mathrm{Na}$ & 22.99 & 201.496 & & & 148.82 & \\
\hline $10 \mathrm{Ni}\left(\mathrm{NO}_{3}\right)_{2} \mathrm{O} \mathrm{H}_{2} \mathrm{O}$ & 290.81 & 1 & 4.56 & 0.0157 & $\mathrm{Ni}$ & 58.70 & 0.920 & 1.94 & & & 1.69 \\
\hline & & & & & $\begin{array}{l}\mathbf{P} \\
\mathrm{Pb}\end{array}$ & & & & & & \\
\hline $16 \mathrm{Pd}\left(\mathrm{NO}_{3}\right)_{2} ; 15.27 \%$ & 230.41 & 0.153 & 0.03 & 0.0000 & $\mathrm{Pd}$ & 106.40 & 0.002 & 0.00 & & & \\
\hline $15 \mathrm{Rh}\left(\mathrm{NO}_{3}\right)_{2} ; 4.93 \%$ & 226.91 & 0.049 & 0.53 & 0.0001 & $R h$ & 102.91 & 0.012 & 0.01 & & & \\
\hline $13 \mathrm{RuCl}_{3} ; 41.74 \%$ & 207.43 & 0.417 & 0.31 & 0.0006 & $\mathrm{Ru}$ & 101.07 & 0.062 & & 0.08 & & \\
\hline $9 \mathrm{Na}_{2} \mathrm{SiO}_{3} \mathrm{OPH}_{2} \mathrm{O}$ & & & & & $\mathrm{Si}$ & 28.09 & 0.379 & & & & \\
\hline & & & & & Sn & & & & & & \\
\hline $19 \mathrm{Sr}\left(\mathrm{NO}_{3}\right)_{2}$ & 211.65 & 1 & 0.17 & 0.0008 & $S r$ & 87.62 & 0.071 & 0.10 & & & \\
\hline $14 \mathrm{TiO}_{2}$ & 79.90 & 1 & 0.07 & 0.0008 & $3 \pi$ & 47.90 & 0.040 & & & & \\
\hline & & & & & V & & & & & & \\
\hline $18 \mathrm{Zn}\left(\mathrm{NO}_{3}\right)_{2} \mathrm{O}_{6} \mathrm{H}_{2} \mathrm{O}$ & 297.47 & 1 & 0.37 & 0.0012 & $\mathrm{Zn}$ & 65.38 & 0.080 & 0.15 & & & 0.13 \\
\hline & & & & & $\mathbf{Z r}$ & & & & & & \\
\hline TOTAL Ad & & & 131 & & & & & & & & \\
\hline TOTAL Calc (g) & & & 1314.21 & & & 900.42 & 281.91 & 469.60 & 0.08 & B 148.82 & 413.79 \\
\hline
\end{tabular}


Table 3 Solution Composition

\begin{tabular}{|c|c|c|c|c|c|c|c|c|c|c|c|}
\hline & & & & & & Table3 & & & & & TOTAL \\
\hline & & & EPARATI & ION & SOLL & UTION & & NSOLUBL & ESOLD & & SLUDGE \\
\hline & & Element & Prepare & 21391 & Analyze & Calc & Calc & 78.572 & Analuse & 36.418 & Average \\
\hline $\mathrm{Sq}$ & 日. & MMt & $g W_{t}$ & $\mathrm{mg} / \mathrm{L}$ & $\mathrm{mg} / \mathrm{L}$ & $g$ in Soltn & $g$ in Soli & Calc Met & $\bar{W} \%$ & Wt\% & $\mathrm{mg} / \mathrm{L}$ \\
\hline & & & & & Solution & & & Solids \% & Solids & Metals & \\
\hline & & & & & & & & & & & \\
\hline 22 & $\mathrm{Na}$ & 22.99 & 201.496 & \begin{tabular}{|l|l|}
94197 \\
\end{tabular} & 94190 & 201.481 & 0.015 & & 1.725 & $4.7 \%$ & 17250 \\
\hline 3 & $\bar{K}$ & 39.10 & 1.423 & 665 & 665.0 & 1.4225 & & & & & \\
\hline 2 & $A$ & 26.98 & 61.597 & 28796 & 158.60 & 0.3393 & 61.258 & $78.0 \%$ & 26.470 & $727 \%$ & 264695 \\
\hline 12 & cr & 52.00 & 0.040 & 19 & 6.360 & 0.0136 & 0.026 & & 0.017 & & 169 \\
\hline 20 & $\mathrm{~B}$ & 10.81 & 0.005 & 2 & 6.085 & 0.0130 & & & 0.009 & & 93 \\
\hline 9 & $\overline{S i}$ & & 0.379 & 177 & 0.617 & 0.0013 & 0.378 & & 0.147 & $0.4 \%$ & 1467 \\
\hline & $\mathrm{Pb}$ & & & 0 & 0.570 & & & & 0.044 & $0.1 \%$ & 437 \\
\hline & $P$ & & & 0 & 0.412 & & & & 0.022 & $0.1 \%$ & 215 \\
\hline & $\mathbf{Z r}$ & & & o & 0.229 & & & . & & & 79 \\
\hline & $\mathrm{Ca}$ & 40.08 & 0.421 & 197 & 0.219 & 0.0005 & 0.420 & $0.5 \%$ & 0.288 & $0.8 \%$ & 2883 \\
\hline & La & & & 0 & 0.196 & & & & & & 68 \\
\hline 10 & $\mathbf{N i}$ & 58.70 & 0.920 & 430 & 0.166 & 0.0004 & 0.920 & $1.2 \%$ & 0.436 & $1.2 \%$ & 4356 \\
\hline & V & & & 0 & 0.145 & & & & & & 50 \\
\hline & Co & & & 0 & 0.128 & & & & 0.004 & & 44 \\
\hline 11 & $a$ & 63.55 & 0.100 & 47 & 0.103 & 0.0002 & 0.100 & $0.1 \%$ & 0.047 & $0.1 \%$ & 474 \\
\hline & Sn & & & 0 & 0.098 & & & & 0.015 & & 149 \\
\hline & $\mathrm{Mo}$ & & & 0 & 0.091 & & & & 0.011 & & 106 \\
\hline 14. & & 47.90 & 0.040 & 19 & 0.091 & 0.0002 & 0.040 & & 0.007 & & 71 \\
\hline & $\mathrm{Fe}$ & 55.85 & 9.799 & 4581 & 0.076 & 0.0002 & 9.799 & $125 \%$ & 4.586 & $126 \%$ & 45863 \\
\hline 17 & $\mathrm{Ba}$ & 137.34 & 0.165 & 77 & 0.059 & 0.0001 & 0.165 & $0.2 \%$ & 0.076 & $0.2 \%$ & 760 \\
\hline & $\mathrm{Cd}$ & & & 0 & 0.042 & & & & 0.002 & & 20 \\
\hline 19 & & 87.62 & 0.071 & 33 & 0.032 & 0.0001 & 0.071 & $0.1 \%$ & 0.034 & $0.1 \%$ & 337 \\
\hline & $\mathrm{Mn}$ & 54.94 & 4.999 & 2337 & 0.028 & 0.0001 & 4.999 & $6.4 \%$ & 2.303 & $6.3 \%$ & 23033 \\
\hline 18 & & 65.38 & 0.080 & 38 & 0.021 & 0.0000 & 0.080 & $0.1 \%$ & 0.035 & $0.1 \%$ & 349 \\
\hline & $\mathrm{Mg}$ & 24.31 & 0.300 & 140 & 0.016 & 0.0000 & 0.300 & $0.4 \%$ & 0.141 & $0.4 \%$ & 1412 \\
\hline 16 & $\mathrm{Pd}$ & 106.40 & 0.002 & 1 & & & & & & & \\
\hline 15 & Rh & 102.91 & 0.012 & 6 & & & & & & & \\
\hline 13 & $\mathrm{Ru}$ & 101.07 & 0.062 & 29 & & & & & & & \\
\hline & & & & & & & & & & & \\
\hline & SUM & & 281.850 & 131761 & 95029 & 203.27 & 78.572 & 0.994 & 36.418 & 0.998 & 364380 \\
\hline
\end{tabular}


Table 4 Sludge Insolubles

\begin{tabular}{|c|c|c|c|c|c|c|c|c|c|c|c|}
\hline & & & & & Table4 & & & & & & \\
\hline & & & EPARAT & $10 N$ & SOL & TION & & NSOLUBI & LESOLD & & SLUDGE \\
\hline & & Eement & PTepare & 21391 & Analyze & Calc & Calc & 78.572 & Analuse & 36.418 & Average \\
\hline $\mathrm{sq}$ & E. & MLI & $g W^{\prime}$ & $\mathrm{mg} / \mathrm{L}$ & $\mathrm{mg} / \mathrm{L}$ & $\mathrm{g}$ in Solth & $g$ in Soli & CalcM+ & Wt \% & W\% & $\mathrm{mg} / \mathrm{L}$ \\
\hline & & & & & Solution & (2.14L) & & Solids \% & Solids & Metals & \\
\hline & & & & & & & & & & & \\
\hline 2 & A & 26.98 & 61.597 & 28796 & 158.603 & 0.3393 & 61.258 & $78.0 \%$ & 26.470 & $727 \%$ & 264695 \\
\hline & $\mathrm{Fe}$ & 55.85 & 9.799 & 4581 & 0.076 & 0.0002 & 9.799 & $12.5 \%$ & 4.586 & $126 \%$ & 45863 \\
\hline & $\mathrm{Mn}$ & 54.94 & 4.999 & 2337 & 0.028 & 0.0001 & 4.999 & $6.4 \%$ & 2.303 & $6.3 \%$ & 23033 \\
\hline 22 & $\overline{\mathrm{Na}}$ & 22.99 & 201.496 & 94197 & 94189.6 & 201.481 & 0.015 & & 1.725 & $4.7 \%$ & 17250 \\
\hline 10 & $\overline{\mathrm{Ni}}$ & 58.70 & 0.920 & 430 & 0.166 & 0.0004 & 0.920 & $1.2 \%$ & 0.436 & $1.2 \%$ & 4356 \\
\hline 6 & $\mathrm{Ca}$ & 40.08 & 0.421 & 197 & 0.219 & 0.0005 & 0.420 & $0.5 \%$ & 0.288 & $0.8 \%$ & 2883 \\
\hline 9 & Si & & 0.379 & 177 & 0.617 & 0.0013 & 0.378 & & 0.147 & $0.4 \%$ & 1467 \\
\hline & $\mathrm{Mg}$ & 24.31 & 0.300 & 140 & 0.016 & 0.0000 & 0.300 & $0.4 \%$ & 0.141 & $0.4 \%$ & 1412 \\
\hline 17 & $\mathrm{Ba}$ & 137.34 & 0.165 & 77 & 0.059 & 0.0001 & 0.165 & $0.2 \%$ & 0.076 & $0.2 \%$ & 760 \\
\hline 11 & $\mathrm{Cu}$ & 63.55 & 0.100 & 47 & 0.103 & 0.0002 & 0.100 & $0.1 \%$ & 0.047 & $0.1 \%$ & 474 \\
\hline & $\mathrm{PD}$ & & & 0 & 0.570 & & & & 0.044 & $0.1 \%$ & 437 \\
\hline 18 & $Z n$ & 65.38 & 0.080 & 38 & 0.021 & 0.0000 & 0.080 & $0.1 \%$ & 0.035 & $0.1 \%$ & 349 \\
\hline 19 & Sr & 87.62 & 0.071 & 33 & 0.032 & 0.0001 & 0.071 & $0.1 \%$ & 0.034 & $0.1 \%$ & 337 \\
\hline & $P$ & & & of & 0.412 & & & & 0.022 & $0.1 \%$ & 215 \\
\hline 12 & $a$ & 52.00 & 0.040 & 19 & 6.360 & 0.0136 & 0.026 & & 0.017 & & 16 \\
\hline & Sn & & & 0 & 0.098 & & & & 0.015 & & 14 \\
\hline & Mo & & & 0 & 0.091 & & & & 0.011 & & 106 \\
\hline 20 & & 10.81 & 0.005 & 2 & 6.085 & 0.0130 & & & 0.009 & & 93 \\
\hline 14 & $\pi$ & 47.90 & 0.040 & 19 & 0.091 & 0.0002 & 0.040 & & 0.007 & & 71 \\
\hline & $C_{0}$ & & & 0 & 0.128 & & & & 0.004 & & 44 \\
\hline & $\overline{C d}$ & & & 0 & 0.042 & & & & 0.002 & & 20 \\
\hline & $\mathbf{Z r}$ & & & 0 & 0.229 & & & & & & 79 \\
\hline & $\mathrm{La}$ & & & 0 & 0.196 & & & & & & 68 \\
\hline & V & & & 0 & 0.145 & & & & & & 50 \\
\hline 3 & $\mathrm{~K}$ & 39.10 & 1.423 & 665 & & 1.4225 & & & & & \\
\hline 16 & $\mathrm{Pd}$ & 106.40 & 0.002 & 1 & & & & & & & \\
\hline 15 & & 102.91 & 0.012 & 6 & & & & & & & \\
\hline 13 & $\mathrm{Ru}$ & 101.07 & 0.062 & 29 & & & & & & & \\
\hline & & & & & & & & & & & \\
\hline & SUM & & 281.850 & 131761 & 94364 & 203.27 & 78.572 & 0.994 & 36.418 & 0.998 & 364380 \\
\hline
\end{tabular}


Table 5 Supernate Adjustment

\section{Table5}

\begin{tabular}{|c|c|c|c|c|c|c|c|c|c|}
\hline FiltrateAdditive.xis & MMt Salt Weight & $\begin{array}{c}\text { Tables } \\
\text { g Na/1.5Ł }\end{array}$ & & $H$ & $\mathrm{Al}(\mathrm{OH})_{4}$ & & $\mathrm{NO}_{2}^{-}$ & $\mathrm{CO}_{3}^{2-}$ & $\mathrm{SO}_{4}^{2-}$ \\
\hline D:lapplStudgelRP42 & $g / \mathrm{L} \quad \mathrm{g} / 1.5 \mathrm{~L}$ & 22.99 & & & $\mathrm{AlO}_{2}^{-}$ & & & & \\
\hline Walker Goal & 10.4 wt\% Ins Solids & & $\mathbf{3 . 4 0}$ & 0.22 & 0.08 & 1.30 & 0.86 & 0.40 & 0.04 \\
\hline SUM & Total Moles, 3L evap to $1.5 \mathrm{~L}$ & 115.17 & 3.34 & 0.22 & 0.08 & 1.30 & 0.86 & 0.40 & 0.04 \\
\hline Current Sol Conc & $1.5 \mathrm{~L}$ & 46.82 & 1.36 & $0 . \overline{20}$ & & 1.16 & & & \\
\hline
\end{tabular}

Makeup Sol Conc $1.5 \mathrm{~L}$

\begin{tabular}{|lrrrrrrrrrr|r|}
\hline $\mathrm{NaOH}$ & 40.00 & 0.80 & 1.20 & 0.69 & 0.02 & 0.02 & & 0.14 & & & \\
$\mathrm{NaNO}_{3}$ & 84.99 & 11.90 & 17.85 & 4.83 & 0.14 & & & 0.14 & & & \\
$\mathrm{NaAl}(\mathrm{OH})_{4}$ & 118.00 & 9.44 & 14.16 & 2.76 & 0.08 & & 0.08 & & & \\
$\mathrm{NaNO}_{2}$ & 69.00 & 59.34 & 89.01 & 29.66 & 0.86 & & & & 0.86 & \\
$\mathrm{Na}_{2} \mathrm{CO}_{3} \mathrm{OH}_{2} \mathrm{O}$ & 124.00 & 49.60 & 74.40 & 27.59 & 0.80 & & & & 0.40 & \\
$\mathrm{Na}_{2} \mathrm{SO}_{4} \mathrm{O}_{10 \mathrm{H}_{2} \mathrm{O}}$ & 322.19 & 13.21 & 19.81 & 2.83 & 0.08 & & & & & 0.041 \\
\hline
\end{tabular}

Vendor Solution Concentration $\quad \mathrm{Na}^{+}$OH $\quad \mathrm{Al}^{3+} \quad \mathrm{NO}_{3}^{-} \quad \mathrm{NO}_{2}^{-} \quad \mathrm{CO}_{3}^{2-} \mathrm{SO}_{4}^{2-}$

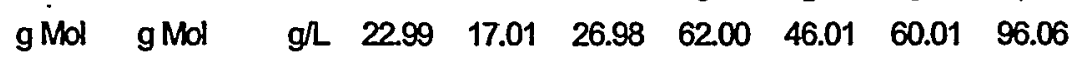
@1.5L@3.0L

\begin{tabular}{|c|c|c|c|c|c|c|c|c|c|c|c|}
\hline $\mathrm{NaOH}$ & 40.00 & 0.22 & 0.11 & $\overline{4.40}$ & 2.53 & $1 . \overline{87}$ & \multirow{3}{*}{\multicolumn{2}{|c|}{40.30}} & & & \\
\hline $\mathrm{NaNO}_{3}$ & 84.99 & 1.30 & 0.65 & 55.24 & 14.94 & & & & \multirow{5}{*}{19.78} & \multirow{5}{*}{12.00} & \\
\hline $\mathrm{NaAlO}_{2}$ & 81.97 & 0.08 & 0.04 & 3.28 & 0.92 & & & & & & \\
\hline $\mathrm{NaNO}_{2}$ & 69.00 & 0.86 & 0.43 & 29.67 & 9.89 & & & & & & \\
\hline $\mathrm{Na}_{2} \mathrm{CO}_{3}$ & 105.99 & 0.40 & 0.20 & 21.20 & 9.20 & & & & & & \\
\hline $\mathrm{Na}_{2} \mathrm{SO}_{4}$ & 142.04 & 0.04 & 0.02 & 2.91 & 0.94 & & & & & & 1.97 \\
\hline \multicolumn{2}{|c|}{ Soluble Salts } & & & 116.70 & 38.42 & 1.87 & 1.08 & 40.30 & 19.78 & 12.00 & 1.97 \\
\hline \multicolumn{2}{|c|}{ Soluble Solids @ 2640 mL } & $71.2 \%$ & & 116.70 & \multicolumn{4}{|c|}{$95.9 \mathrm{mg} / \mathrm{L}$ Measured p 57} & & & \\
\hline \multicolumn{2}{|c|}{ Ins Solids @2640 mL } & $28.8 \%$ & 41.6 & 47.27 & \multicolumn{4}{|c|}{$46.6 \mathrm{mg} / \mathrm{L}$. Measured p 59} & & & \\
\hline \multicolumn{2}{|c|}{ Total Evaporated Solids } & $100.0 \%$ & & 163.97 & & & & & & & \\
\hline Analytice & & & & & 38.01 & & 0.965 & 42.99 & 19.02 & & 2.04 \\
\hline
\end{tabular}


Table 6 Mercury Fulminate Decomposition Temperature Reconciliation

\begin{tabular}{|c|c|c|c|c|c|c|c|c|}
\hline & & Mercuru Ful & minate $D$ & ecompos & sition Tem & erature & & \\
\hline D:lapplstuc & dgel[ReportT & [ables.xis] & \begin{tabular}{|l|} 
Table 6 \\
\end{tabular} & & & & & \\
\hline Chilworth & Mercury Ful & Iminate & & & & & 4.182 & 1 \\
\hline & & & Exotherm & Peak Te & mperature, & ${ }^{\circ} \mathrm{C}(1)$ & & \\
\hline$D S C$ & 1 to $5 \mathrm{mg}$ & $10^{\circ} \mathrm{C} / \mathrm{min}$ & 200 & $200-220$ & $221-240$ & $>240$ & $\mathrm{~J} / \mathrm{g}$ & Callg \\
\hline Al Cup & Open & ChFig12 & & & 233 & & Base shift & 34 \\
\hline & Low seal & ChFig7 & & & 236 & 245 & & 56 \\
\hline & Low seal & ChFig8 & & & 232 & 242 & & 55 \\
\hline & Crimped & ChFig11 & 180 & & 230 & 242 & Base shift & 21 \\
\hline & & & & & & & & \\
\hline Cu Cup & Sealed & ChFig9 & 181 & & 230 & 243 & Base shift & 26 \\
\hline & Sealed & ChFig10 & 181 & & 229 & 244 & Base shift & 36 \\
\hline & & & & & & & & \\
\hline Au Cup & Lose cover & Fondeur & 170 & & 235 & & 130 & 31 \\
\hline & & & 170 & 219 & 235 & & 130 & 31 \\
\hline & & & & & & & & \\
\hline & & Average & & & & & & 36 \\
\hline & & & & & & & & \\
\hline "Canius" Se & aled Tube & & & & & & & \\
\hline & $10 \mathrm{~g}$ & $0.5^{\circ} \mathrm{C} / \mathrm{min}$ & & & & & & \\
\hline Pure Fulmir & nate & & 188 & & & & $188^{\circ} \mathrm{C}$ & rSurge \\
\hline & & & & & & & & \\
\hline SRTC Merc & oury Fulmin & & & & & & & \\
\hline$D S C$ & $3 \mathrm{mg}$ & $10^{\circ} \mathrm{C} / \mathrm{min}$ & Exotherm & Peak Ter & mperature, & & $\mathrm{J} / \mathrm{g}$ & Callg \\
\hline Au Cup & Lose cover & Ref. 2, Fig11 & 167 & & & & 182 & 44 \\
\hline NewPrep & Lose cover & Fondeur & 176 & & & & 251 & 60 \\
\hline & & Average & & & & & & 52 \\
\hline & & & & & & & & \\
\hline NewDSC & Lose cover & Fondeur5/21 & 176 & & & & 400 & 96 \\
\hline & & & & & & & & \\
\hline Open Capill & lary Tube & & & & & & & \\
\hline & $2 \mathrm{mg}$ & $5^{\circ} \mathrm{C} / \min$ & 188 & & & & & \\
\hline & & & & & & & & \\
\hline Literature & Mercury Fulr & minate Decor & mposition & Temper & ature $\left({ }^{\circ} \mathrm{C}\right)$ & & & \\
\hline & Sample WL & $(m g)$ & 0.8 & 1.6 & 6.5 & 25 & & \\
\hline & & & & & & & & \\
\hline Heating Rat & te, ${ }^{\circ} \mathrm{C} / \mathrm{min}$ & 10 & 155 & 151 & 148. & 146 & & \\
\hline & & 20 & 158 & 156 & 153 & 152 & & \\
\hline & & 30 & & 163 & 159 & 158 & & \\
\hline (1) & Bold signifie & es major peak & & & & & & \\
\hline
\end{tabular}


Table 7 Mercury Fulminate Decomposition in Dry Sludge

\begin{tabular}{|c|c|c|c|c|c|c|c|c|c|}
\hline & & \multicolumn{5}{|c|}{ Mercuru Fulminate in Dry Sludge Decomposition } & & & \\
\hline \multicolumn{3}{|c|}{ D:lapplSludgel[ReportTables.xls] } & Table 7 & & & & & & \\
\hline & & & & & & & & & \\
\hline \multicolumn{10}{|c|}{ Differential Scanning Calorimetry (DSC) Testing } \\
\hline \multicolumn{2}{|c|}{ Temperature Rate: } & $10^{\circ} \mathrm{C} / \mathrm{min}$ & & & & & & & \\
\hline & & & & & & & & & \\
\hline \multicolumn{3}{|c|}{ Chilworth Technology Data } & \multicolumn{3}{|c|}{ Exotherm Peak Temp. (1) } & Sample Wt & 4.182 & 1 & \\
\hline$\% \mathrm{MF}$ in & Sludge & & ${ }^{\circ} \mathrm{C}$ & ${ }^{\circ} \mathrm{C}$ & ${ }^{\circ} \mathrm{C}$ & $\mathrm{mg}$ & $\mathrm{J} / \mathrm{g}$ & al/g MF & \\
\hline $5.0 \%$ & Caustic & ChFig16 & 181 & 192 & & 14.8 & & 69 & \\
\hline $5.0 \%$ & Caustic & ChFig17 & 182 & 192 & & 20.5 & & 75 & \\
\hline $10.0 \%$ & Caustic & ChFig18 & 182 & 191 & 205 & 13.2 & & 101 & \\
\hline \multirow[t]{3}{*}{$10.0 \%$} & Caustic & ChFig19 & 183 & 192 & & 20.6 & & 103 & \\
\hline & & Average & 182 & 192 & & & & 87 & \\
\hline & & & & & & & & & \\
\hline \multirow{2}{*}{$10.0 \%$} & Neutral & \multicolumn{3}{|c|}{ Sludge Endotherm Interferance } & & & & & \\
\hline & & & \multirow{2}{*}{\multicolumn{3}{|c|}{$\frac{1}{\text { Exotherm Peak Temp. (1) }}$}} & & & & \\
\hline \multicolumn{2}{|c|}{ SRTC Data } & & & & & Sample Wt & & & \\
\hline$\% M F$ in & Sludge & & ${ }^{\circ} \mathrm{C}$ & ${ }^{\circ} \mathrm{C}$ & & $\mathrm{ng}$ & $\mathrm{J} / \mathrm{g}$ Sample & al/g MF & \\
\hline $2.2 \%$ & Caustic & SRTC12U & 169 & 180 & & 4.6 & 11.9 & 129 & \\
\hline 9.3\% & Caustic & SRTC12L & 170 & 180 & & 6.0 & 20.3 & 52 & \\
\hline \multirow[t]{3}{*}{$21.5 \%$} & Caustic & SRTC12H & 169 & 180 & & 6.7 & 28.8 & 32 & \\
\hline & & Average & 169 & 180 & & & & 71. & \\
\hline & & & & & & & & & \\
\hline \multicolumn{10}{|c|}{ Chilworth $\mathbf{1 0}$ wt\% Mercury Fulminate in Sludge - "Carius Tube" Tests } \\
\hline \multicolumn{2}{|c|}{ Temperature Rate: } & $0.5^{\circ} \mathrm{C} / \min$ & & & & & & & \\
\hline & & & & & & Gas (2) & & Pressure & \\
\hline & & Total Sampl & Exotherm & Peak Ten & .(1) & Generated & Pressure & $@ 500 \%$ & \\
\hline \multirow[t]{2}{*}{ Test } & Sludge & g & ${ }^{\circ} \mathrm{C}$ & ${ }^{\circ} \mathrm{C}$ & ${ }^{\circ} \mathrm{C}$ & $\infty \mathrm{clg} M \mathrm{~F}$ & Inflection & barg & \\
\hline & & & & & & & & & Strong \\
\hline \multirow[t]{2}{*}{ Control } & Fulminate & 2.4 & & & 184 & 120 & $184^{\circ} \mathrm{C}$ & 21 & Pressure \\
\hline & & & & & & & & & Spike \\
\hline $\operatorname{Rin} 1$ & Caustic & 2.9 & & \multicolumn{2}{|c|}{ No Exotherms } & 32 & $171^{\circ} \mathrm{C}$ & 4.2 & Pr. Blip \\
\hline $\operatorname{Rin} 2$ & Neutral & 3.0 & \multicolumn{3}{|c|}{ No Exotherms } & 117 & $171^{\circ} \mathrm{C}$ & 6.1 & \\
\hline $\operatorname{Rin} 3$ & Caustic & 10.0 & 123 & 140 & & 57 & $144^{\circ} \mathrm{C}$ & 9.6 & Pr. Spike \\
\hline $\operatorname{Ren} 4$ & Neutral & 10.0 & 125 & 164 & 187 & 124 & $185^{\circ} \mathrm{C}$ & 30 & Pr. Blip \\
\hline \multirow[t]{4}{*}{$\operatorname{Rin} 5$} & Neutral & 10.0 & 125 & 178 & 194 & & $170^{\circ} \mathrm{C}$ & 33 & Pr. Blip \\
\hline & & Average & 124 & & & & $168^{\circ} \mathrm{C}$ & & \\
\hline & & \multicolumn{4}{|c|}{ Average gas generated in Caustic Sludge } & 45 & & & \\
\hline & & \multicolumn{4}{|c|}{ Average gas generated in Neutral Sludge } & 120 & & & \\
\hline NOTES: & & & & & & & & & \\
\hline (1) & Bold signi & ies major peak & & & & & & & \\
\hline (2) & Total gas: & enerated at ST & TP, base & UiI & to roor & ere & & & \\
\hline
\end{tabular}


Figure 1 Caustic Sludge Drying in a Beaker 100-mL Beaker, 2in. diameter, 3 in. high.

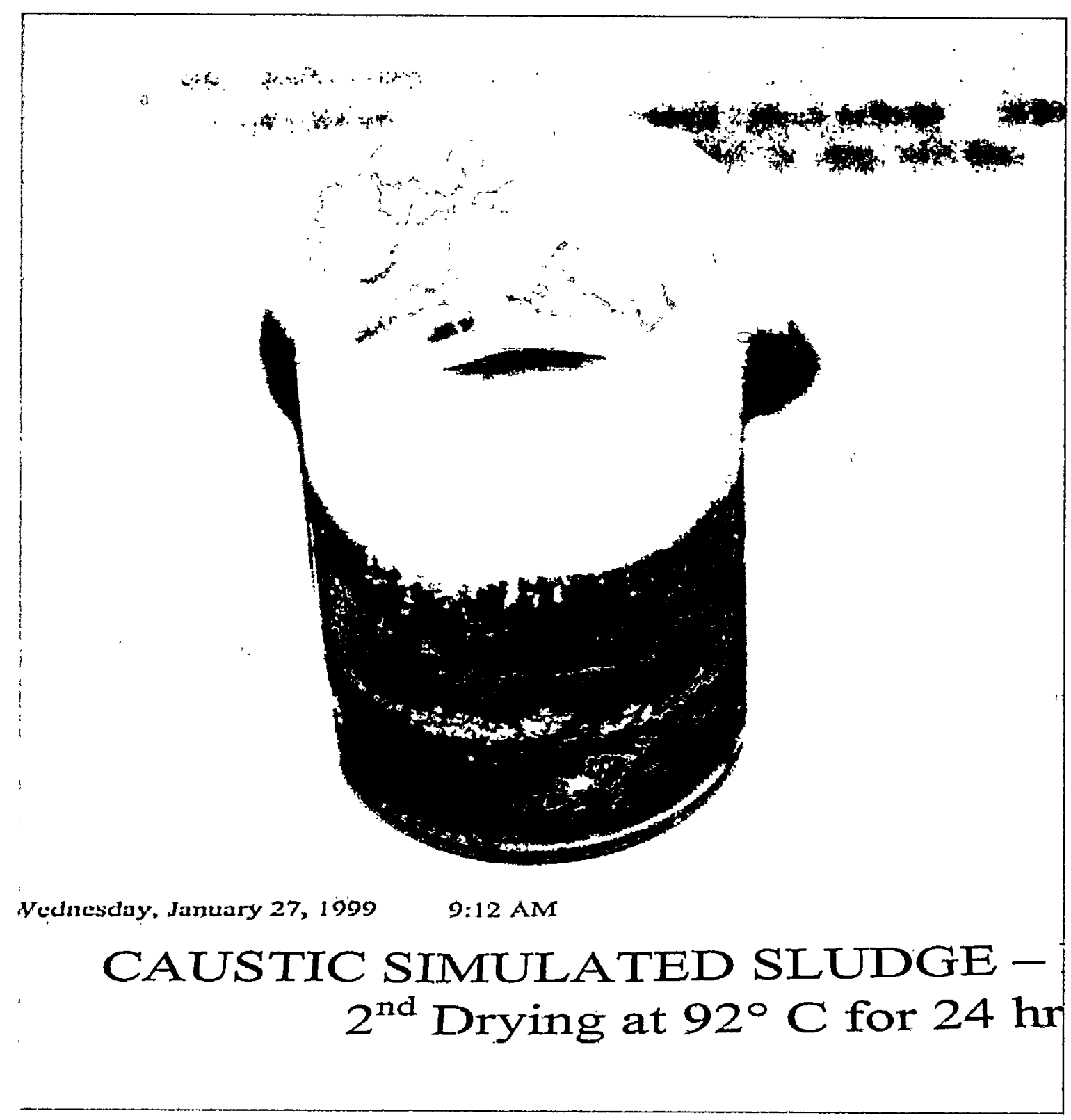


Figure 2 Salt Deposits on Beaker Wall, above Slurry Level 100-mL Beaker Edge, Approx. 6X.

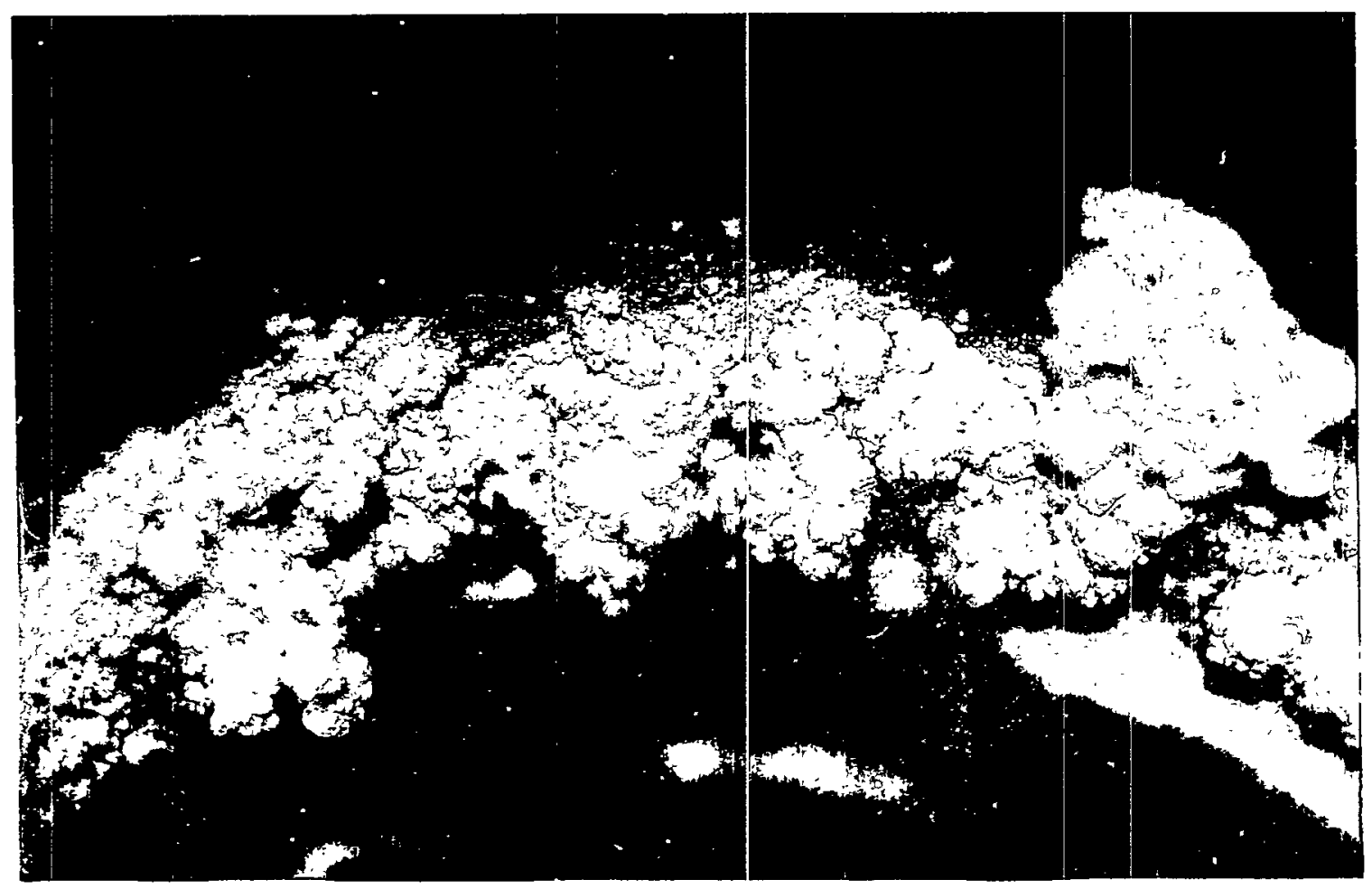


Figure 3 Neutral Sludge Drying in a Beaker

100-mL Beaker, 2in. diameter, 3 in. high.

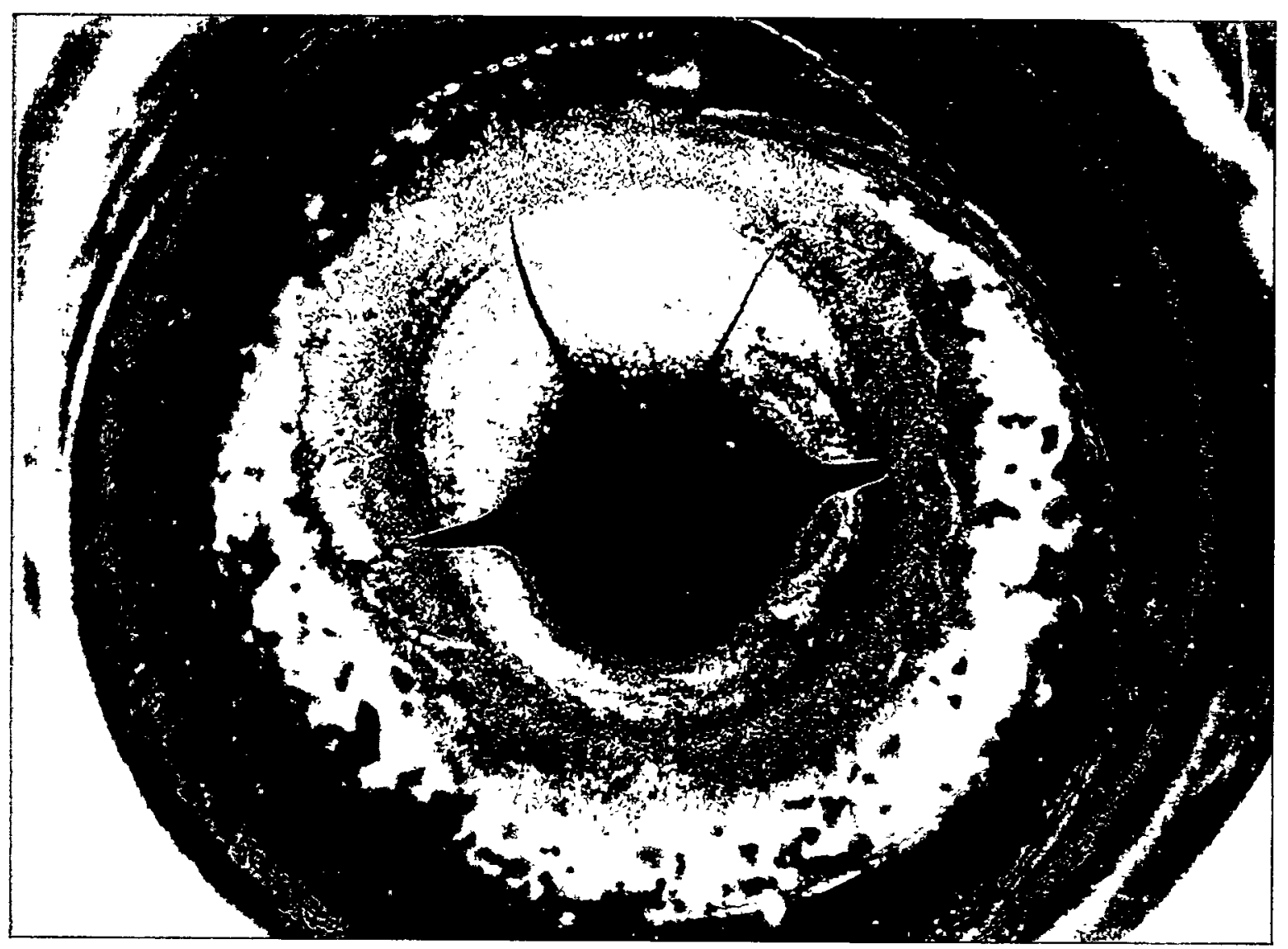


Figure 4 Neutral Nitrate Salt Deposits on Beaker Wall

100-mL Beaker, 2in. diameter, 3 in. high. Approx. 6X.

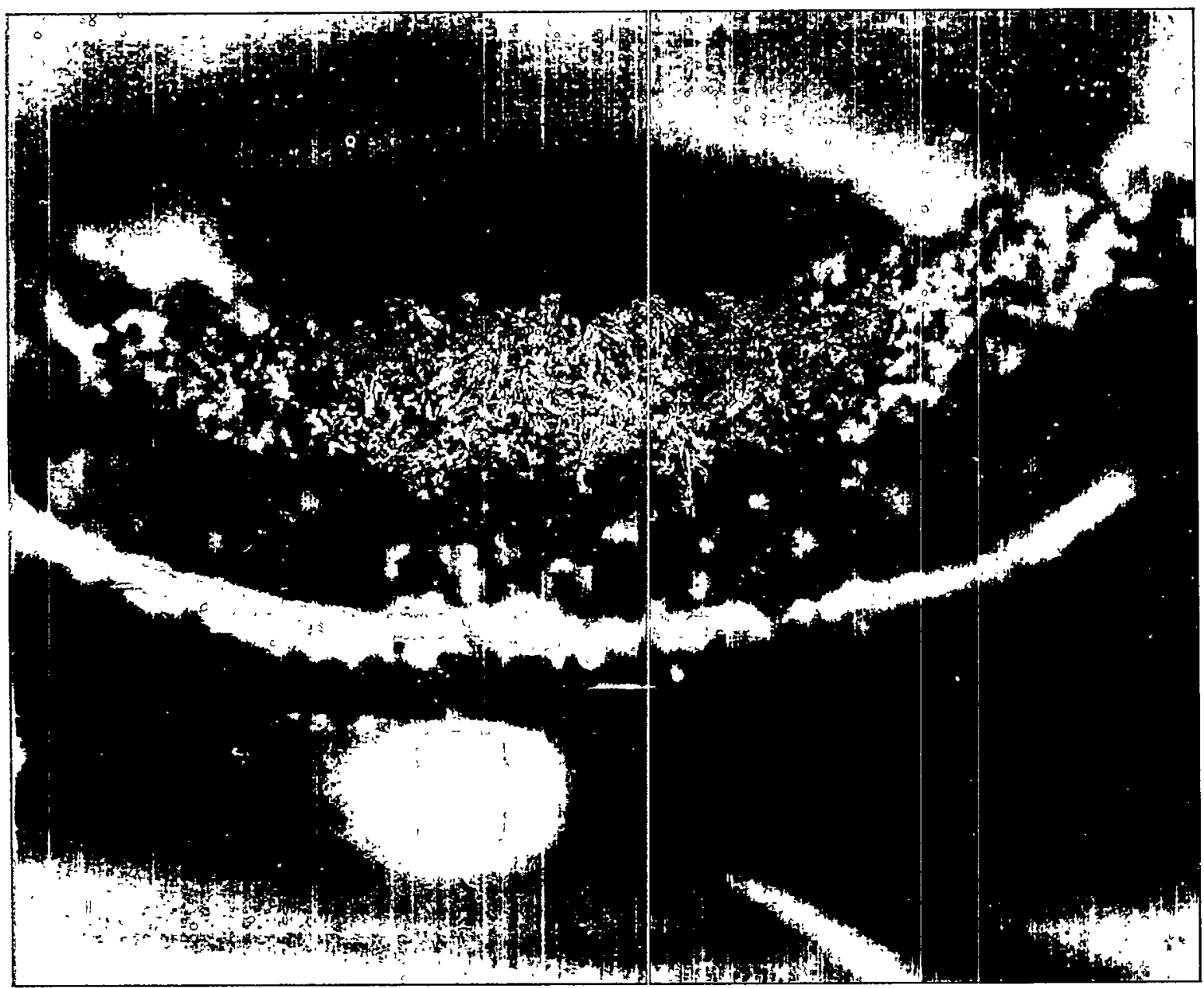


Figure 5 Vendor Caustic Sludge Aging on Glass Slide Approx. 8X

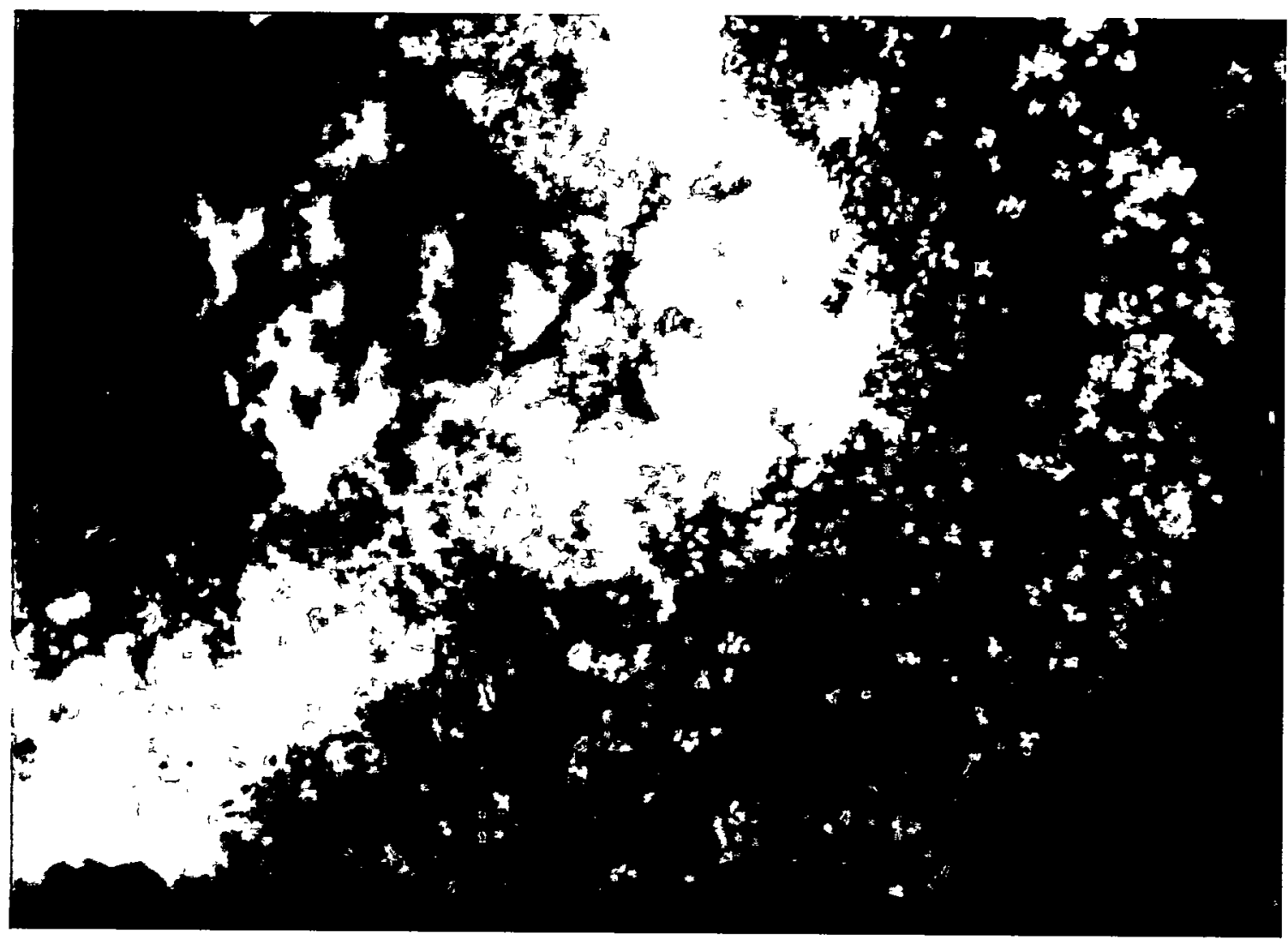




\section{Figure 6 Layers of Ground Dry Sludge before Mixing}

Square bottle, $1-3 / 4$ in. $X$ in.1-3/4

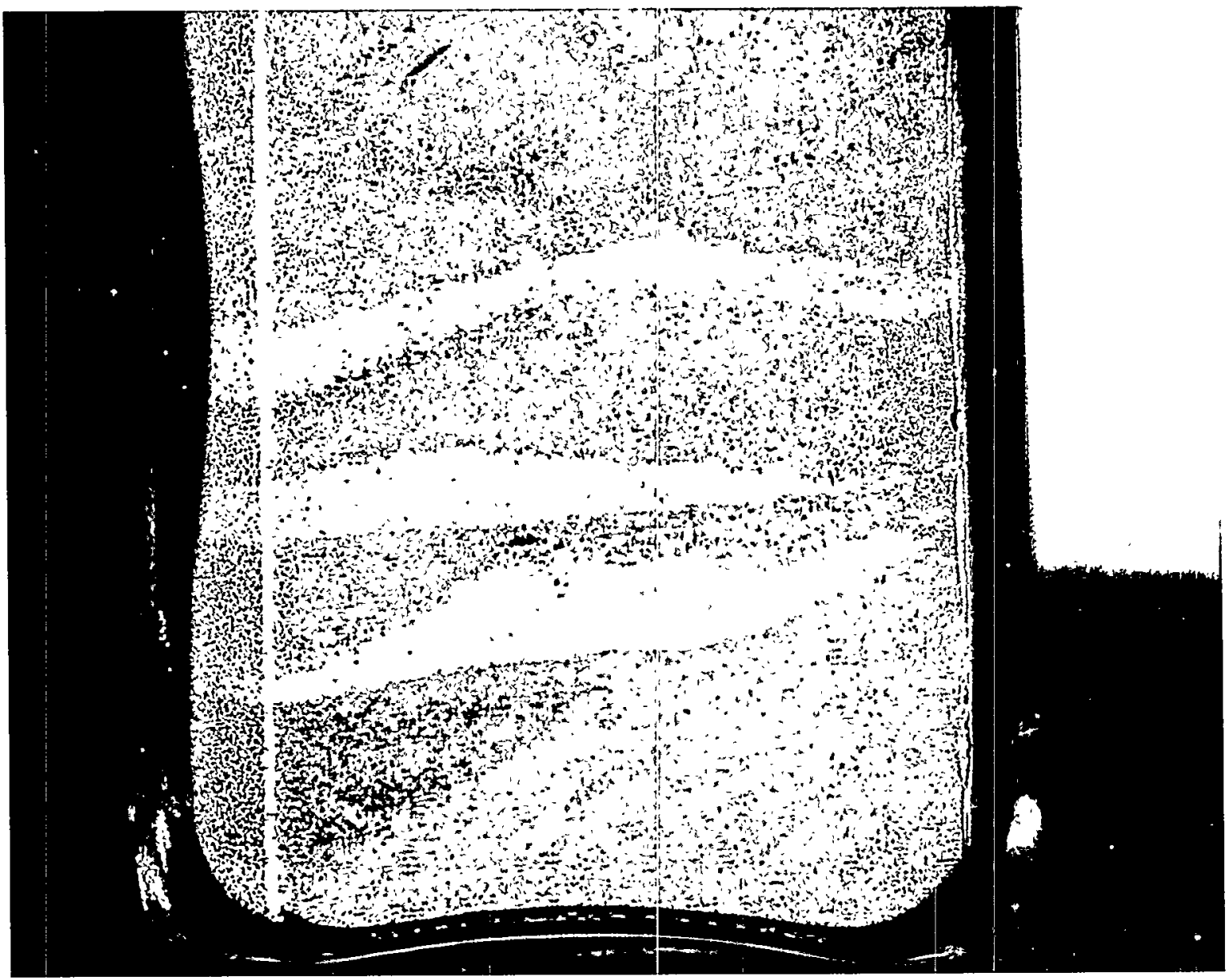


Figure 7 Mercury Fulminate Impact Residue - NO GO $150 \mathrm{X}$

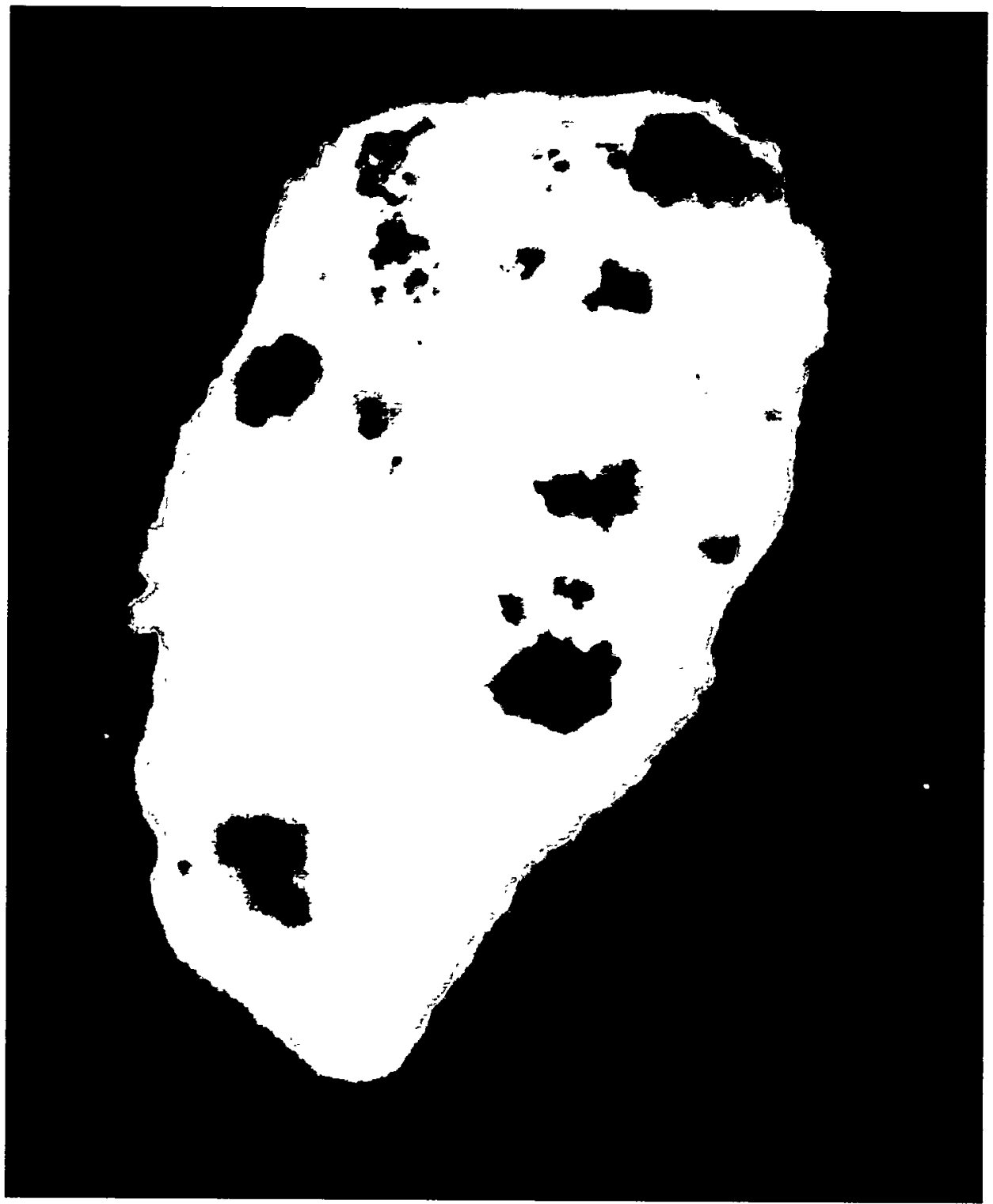


Figure 8 Mercury Fulminate Impact Residue -- Reacted (GO)

\section{$150 \mathrm{X}$}

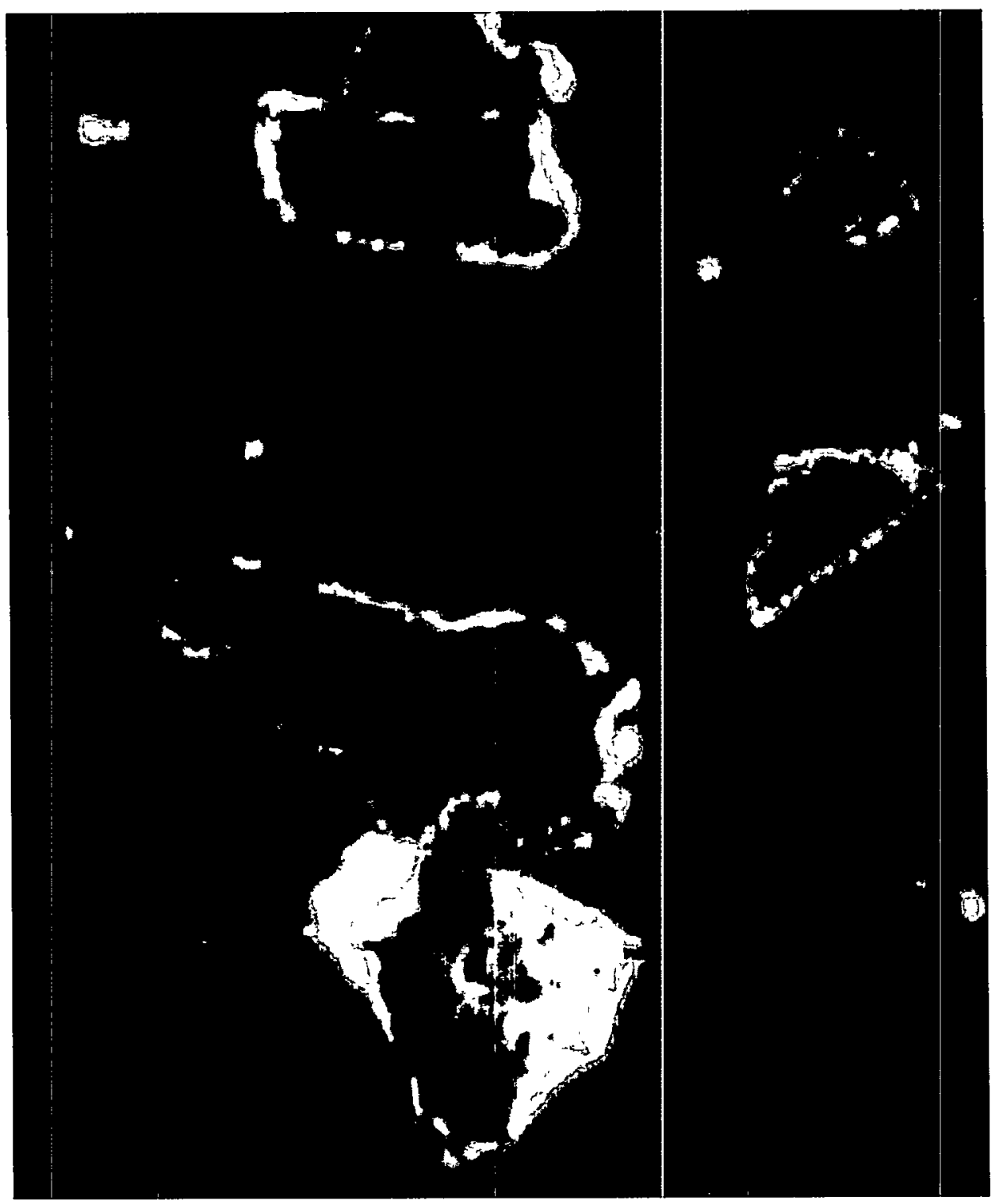


Figure 9 DSC of Mercury Fulminate Hammer Test Residue

$\square S C(G R N) \begin{array}{ll}\text { SMPL ID : pure fuIminate } & \text { COMMENT : R.C. WEDLICH } \\ \text { SMPL ID : fulminate } & \text { COMMENT : R.C. WEDLICH }\end{array}$

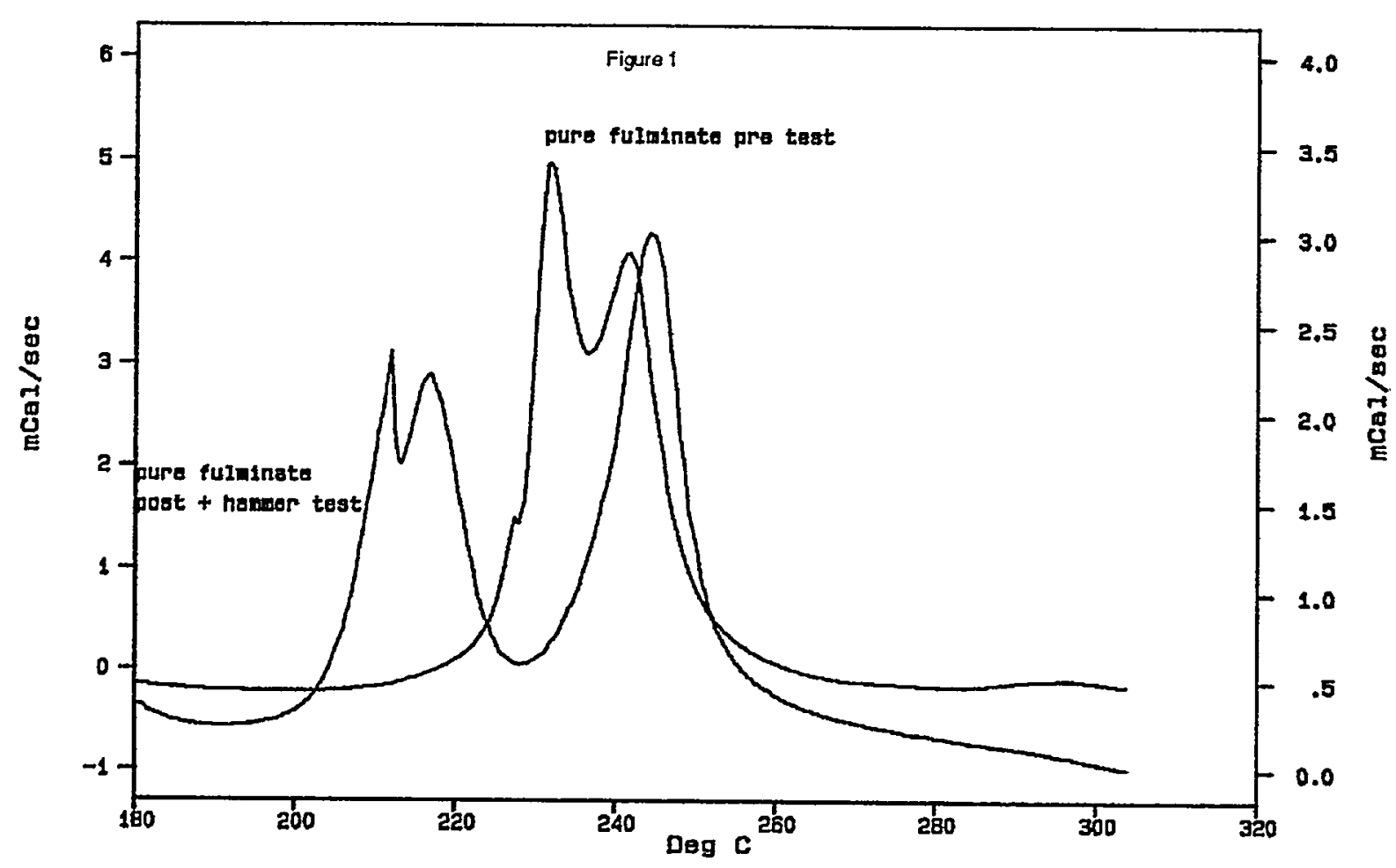


Figure 10 Mercury Fulminate Decomposition Induction Time

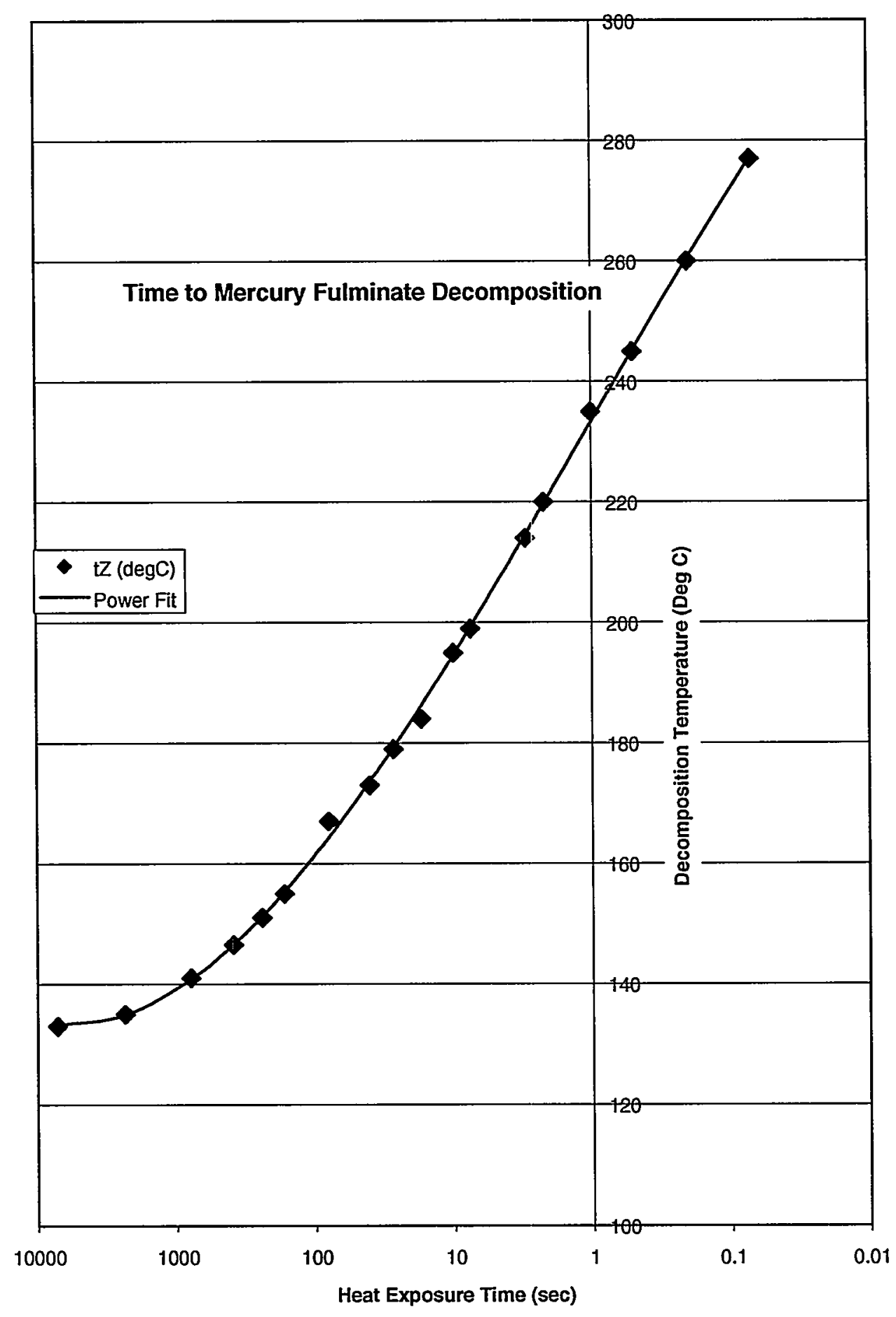




\title{
Appendix A \\ Westinghouse Savannah River Company Savannah River Technology Center
}

\author{
FACSIMILE
}

\author{
TO: Dr. Doug Olson \\ Research Center for Energetic Materials \\ New Mexico Tech \\ 801 Leroy Place \\ Socorro, NM 87801 \\ Tel (505) 835-5733 \\ Fax (505) 835-5630 \\ From: Lee Dworjanyn, \\ SRS, Bdg. 735-11A \\ Aiken, SC 29808 \\ Tel (803) 725-3515 \\ FAX (803) 725-4704 \\ E-mail: lee.dworjanyn@srs.gov
}

Friday, September 25, 1998

\section{Dry sludge Safety Characterization.}

As per my e-mail to Prof. Per-Anders Persson, we need to asses our High Level Waste (HLW) dry sludge residue, stored in $1 \mathrm{MM}$ gal tanks, for potential explosives in the solids phase, and possibly in the vapor head space. The sludge is basically insoluble residue from fuel rod digestion and contains mainly aluminum, iron, manganese, and mercury as shown in attached table. Normally the sludge is kept in residual caustic solution, rinsed, then combined with glass frit and processed to HLW glass for final disposal of the waste. Recently we have found that the sludge has dried out in some of the tanks, and the concern is that explosive compounds may have formed, presenting a risk in sampling and waste recovery. Potential explosive compounds are:

1. Mercury fulminate, $\mathrm{Hg}(\mathrm{ONC})_{2}$, (up to 6 wt $\%$ total $\mathrm{Hg}$ ) 
2. Mercury oxalate, $\mathrm{Hg}_{2} \mathrm{C}_{2} \mathrm{O}_{4}$, (up to $6 \mathrm{wt} \%$ total $\mathrm{Hg}$ ), and 3. Silver nitride, $\mathrm{Ag}_{3} \mathrm{~N}$ (up to 0.01 wt $\%$ ).

We have no direct evidence that these or other explosive compounds are present in the sludge. However if we assume worst case compositions and demonstrate sludge safety, this will meet our objectives. We are currently preparing simulated non-radioactive sludge, and we are looking to you to prepare some standard explosive compositions for incorporating with the sludge for testing. Some of the tests we are considering are:

1. Impact testing

2. Friction testing

3. Thermal decomposition

4. Spark initiation

5. Other?

We are interested in what testing you recommend, and which tests you can run. Also, we would like some input on trace analyses for mercury explosive compounds. I would like to meet with you shortly to evaluate your facilities and discuss your recommendations.

Sincerely,

CC: W. L. Tamosaitis, 773A

S. D. Fink. 773-A

R. F. Swingle, 773-A

IBM_D:lapplSludgelRP428\RP428AppABC.doc 
L. O. Dworjanyn WSRC-RP-99-00428, Appendix A

HLW Sludge Composition

\begin{tabular}{|c|c|c|c|c|c|}
\hline \multicolumn{3}{|c|}{ Elemental Analysis } & \multicolumn{3}{|c|}{ Molecular Analysis } \\
\hline Element & $\begin{array}{c}\text { Molecular } \\
\text { Weight }\end{array}$ & $\begin{array}{l}\text { Conc. } \\
\text { (wt \%) }\end{array}$ & $\begin{array}{l}\text { Sludge } \\
\text { Species }\end{array}$ & $\begin{array}{l}\text { Molecular } \\
\text { Weight }\end{array}$ & $\begin{array}{l}\text { Conc. } \\
\text { (wt \%) }\end{array}$ \\
\hline $\mathrm{Fe}$ & 55.85 & 4.9000 & $\mathrm{Fe}(\mathrm{OH})_{3}$ & 106.87 & 8.30 \\
\hline$\overline{A l}$ & 26.98 & 30.8000 & $\mathrm{Al}(\mathrm{OH})_{3}$ & 78.00 & 78.77 \\
\hline $\mathrm{Na}$ & 22.99 & 2.4000 & $\begin{array}{l}\mathrm{NaOH} \\
\mathrm{NaNO}_{3} \\
\mathrm{Nal} \\
\mathrm{NaCl} \\
\mathrm{Na}_{2} \mathrm{SO}_{4} \\
\mathrm{Na}_{3} \mathrm{PO}_{4} \\
\mathrm{NaF}_{4} \\
\mathrm{Na}_{2} \mathrm{CO}_{3} \\
\mathrm{NaNO}_{2} \\
\end{array}$ & $\begin{array}{r}40.00 \\
84.99 \\
149.90 \\
58.44 \\
142.04 \\
163.94 \\
41.99 \\
105.99 \\
69.00 \\
\end{array}$ & 3.69 \\
\hline $\mathrm{K}$ & 39.10 & 0.0000 & $\begin{array}{l}\mathrm{KNO}_{3} \\
\mathrm{KOH}\end{array}$ & $\begin{array}{r}101.10 \\
56.11 \\
\end{array}$ & 0.00 \\
\hline$M n$ & 54.94 & 2.5000 & $\mathrm{MnO}_{2}$ & 86.94 & 3.50 \\
\hline $\mathrm{Ca}$ & 40.08 & 0.2100 & $\begin{array}{l}\mathrm{CaCO}_{3} \\
\mathrm{CaSO}_{4} \\
\mathrm{Ca}_{3}\left(\mathrm{PO}_{4}\right)_{2} \\
\end{array}$ & $\begin{array}{l}100.09 \\
136.14 \\
310.17 \\
\end{array}$ & 0.46 \\
\hline $\mathrm{Mg}$ & 24.31 & 0.1500 & $\mathrm{MgO}$ & 40.30 & 0.22 \\
\hline $\mathrm{Si}$ & 28.09 & 0.1900 & $\mathrm{SiO}_{2}$ & 60.08 & 0.36 \\
\hline $\mathrm{Ni}$ & 58.69 & 0.4600 & $\mathrm{Ni}(\mathrm{OH})_{2}$ & 92.70 & 0.64 \\
\hline $\mathrm{Cu}$ & 63.55 & 0.0500 & $\mathrm{CuO}$ & 79.55 & 0.06 \\
\hline $\mathrm{Cr}$ & 52.00 & 0.0200 & $\mathrm{Cr}_{2} \mathrm{O}_{3}$ & 151.99 & 0.05 \\
\hline $\mathrm{Ru}$ & 101.07 & 0.0640 & $\mathrm{RuO}_{2}$ & 133.07 & 0.07 \\
\hline $\mathrm{B}$ & 10.81 & 0.0100 & $\mathrm{Na}_{2} \mathrm{~B}_{4} \mathrm{O}_{7}$ & 201.22 & 0.16 \\
\hline$P$ & 30.97 & 0.3000 & $\mathrm{PO}_{4}$ & 94.97 & 0.81 \\
\hline $\mathrm{Ti}$ & 47.88 & 0.0200 & $\mathrm{TiO}_{2}$ & 79.90 & 0.03 \\
\hline $\mathrm{Rh}$ & 102.91 & 0.0130 & $\mathrm{Rh}_{2} \mathrm{O}_{3}$ & 253.81 & 0.03 \\
\hline $\mathrm{Pd}$ & 106.42 & 0.0020 & $\mathrm{PdO}$ & 122.40 & 0.00 \\
\hline $\mathrm{Ag}$ & 107.87 & 0.0003 & $\mathrm{AgO}$ & 123.87 & 0.0003 \\
\hline $\mathrm{Hg}$ & 200.59 & 2.5000 & $\mathrm{HgO}$ & 216.59 & 2.39 \\
\hline $\mathrm{Ba}$ & 137.33 & 0.0824 & $\mathrm{BaSO}_{4}$ & 233.40 & 0.12 \\
\hline $\mathrm{Zr}$ & 91.22 & 0.1851 & $\mathrm{ZrO}_{2}$ & 123.22 & 0.22 \\
\hline $\mathrm{Zn}$ & 65.39 & 0.0402 & $\mathrm{ZnO}$ & 81.37 & 0.04 \\
\hline $\mathrm{Sr}$ & 87.62 & 0.0356 & $\mathrm{SrCO}_{3}$ & 147.63 & 0.05 \\
\hline Total & & 4.93 & & & 100 \\
\hline
\end{tabular}




\section{Appendix B. \\ Caustic Simulated Sludge Preparation}

Date:

Technician:

Activity:

Researcher:

Program Manager:

1.0 - Introduction:

These instructions are for the preparation of Tank $15 \mathrm{H}$ sludge.
Friday, December 11, 1998

Lynda Wingard_

LWWWTE21W

Lee Dworjanyn (M. J. Barnes Procedure, Mike Hay - Alternate)

\section{0 - Objectives:}

\subsubsection{Prepare a sludge solution}

\section{0 - Safety}

3.0.1 Don lab coat and gloves. Work will involve using 50 wt \% $\mathrm{NaOH}$. Care should be taken during sludge preparation. Unless otherwise noted, all additions should take place slowly and in a hood with the sash lowered.

\section{0 - Housekeeping}

4.0.1 Maintain acceptable housekeeping standards.

\section{0 - Documentation}

5.0.1 Place completed Instructions in the Laboratory notebook and provide researcher with a copy. Record all observations.

\section{0 - Waste Disposal}

6.0.1 Any waste produced as part of this work is expected to be non-hazardous. $\mathrm{pH}$ of the solution should be measured before disposal. 


\subsection{Sludge Preparation.}

7.1. Obtain the following chemicals. Record the M\&TE identifier for the balance and weight set used.

\begin{tabular}{|c|c|c|c|c|}
\hline $\begin{array}{l}\text { Chemical } \\
\text { Additive }\end{array}$ & $\begin{array}{l}\text { Mol. Wt. } \\
\text { (g/mole) }\end{array}$ & $\begin{array}{l}\text { Required } \\
\text { Mass (g) }\end{array}$ & $\begin{array}{c}\text { Mass } \\
\text { Uised (g) }\end{array}$ & $\begin{array}{c}\text { Manufacturer } \\
\text { \& Lot \# }\end{array}$ \\
\hline $\mathrm{Fe}\left(\mathrm{NO}_{3}\right)_{3} \bullet 9 \mathrm{H}_{2} \mathrm{O}$ & 404.00 & 70.89 & 70.89 & Records on file \\
\hline $\mathrm{Al}\left(\mathrm{NO}_{3}\right)_{3} \bullet 9 \mathrm{H}_{2} \mathrm{O}$ & 375.13 & 856.4 & 856.4 & \\
\hline $\mathrm{KMnO}_{4}$ & 158.04 & 5.75 & 5.7523 & \\
\hline $\mathrm{Mn}\left(\mathrm{NO}_{3}\right)_{2} / 50.3 \%$ & 178.95 & 19.43 & 19.44 & \\
\hline $\mathrm{Ca}\left(\mathrm{NO}_{3}\right)_{2} \cdot 4 \mathrm{H}_{2} \mathrm{O}$ & 236.15 & 2.48 & 2.4784 & \\
\hline $\mathrm{Mg}\left(\mathrm{NO}_{3}\right)_{2} \bullet 6 \mathrm{H}_{2} \mathrm{O}$ & 256.41 & 3.16 & 3.16 & \\
\hline $\mathrm{Na}_{2} \mathrm{SiO}_{3} \bullet 9 \mathrm{H}_{2} \mathrm{O}$ & 284.20 & 3.84 & 3.84 & \\
\hline $\mathrm{Ni}\left(\mathrm{NO}_{3}\right)_{2} \bullet 6 \mathrm{H}_{2} \mathrm{O}$ & 290.81 & 4.56 & 4.56 & \\
\hline $\mathrm{Cu}\left(\mathrm{NO}_{3}\right)_{2} \cdot 2.5 \mathrm{H}_{2} \mathrm{O}$ & 232.60 & 0.366 & 0.3667 & \\
\hline $\mathrm{Cr}\left(\mathrm{NO}_{3}\right)_{3} \cdot 9 \mathrm{H}_{2} \mathrm{O}$ & 400.15 & 0.308 & 0.3086 & \\
\hline $\mathrm{RuCl}_{3} \cdot \mathrm{XH}_{2} \mathrm{O}$ & 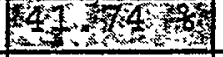 & 0.307 & 0.3055 & \\
\hline $\mathrm{TiO}_{2}$ & 79.90 & 0.067 & 0.067 & \\
\hline $\mathrm{Rh}\left(\mathrm{NO}_{3}\right)_{3}$ & $25 \times 3$ & 0.527 & 0.5254 & \\
\hline $\mathrm{Pd}\left(\mathrm{NO}_{3}\right)_{2}$ & $15,27,8$ & 0.026 & 0.0260 & \\
\hline $\mathrm{Ba}\left(\mathrm{NO}_{3}\right)_{2}$ & 261.35 & 0.314 & 0.3146 & \\
\hline $\mathrm{Zn}\left(\mathrm{NO}_{3}\right)_{2} \bullet 6 \mathrm{H}_{2} \mathrm{O}$ & 297.47 & 0.366 & 0.3659 & \\
\hline $\mathrm{Sr}\left(\mathrm{NO}_{3}\right)_{2}$ & 211.65 & 0.172 & 0.1728 & \\
\hline $\mathrm{Na}_{2} \mathrm{~B}_{4} \mathrm{O}_{7} \cdot 1 \mathrm{OH}_{2} \mathrm{O}$ & 381.37 & 0.176 & 0.1763 & \\
\hline $\mathrm{NaOH}$ & 40.00 & 350 & & \\
\hline
\end{tabular}

7.2 Prepare $700 \mathrm{~g}$ of $50 \mathrm{wt} \% \mathrm{NaOH}$. Mix $350 \mathrm{~g}$ of $\mathrm{NaOH}$ with $350 \mathrm{~g}$ of water.

7.3 Mix $19.43 \mathrm{~g}$ of $\mathrm{Mn}(\mathrm{NO} 3) 2$ solution with $150 \mathrm{~mL}$ of water in a $2 \mathrm{~L}$ beaker at 35 to $40^{\circ} \mathrm{C}$

Label: Solution 1: nvoose

7.4 In a $250 \mathrm{~mL}$ flask, dissolve $5.75 \mathrm{~g}$ of $\mathrm{KMnO} 4$ in $150 \mathrm{~mL}$ of water at 35 to $40^{\circ} \mathrm{C}$

Label: Solution 2

7.5 Add Solution 2 to Solution 1 slowly over 1 hour - Maintain at 35 to $40^{\circ} \mathrm{C}$.

7.6 Dissolve $70.89 \mathrm{~g} \mathrm{Fe}(\mathrm{NO} 3) 3 \mathrm{i} 9 \mathrm{H} 2 \mathrm{O}$ in $150 \mathrm{~mL}$ of water. 
Label: Solution 3

7.7 Add Solution 3 to Solution 1. Maintain at 35 to $40^{\circ} \mathrm{C}$.

7.8 Dissolve $856.4 \mathrm{~g} \mathrm{Al}(\mathrm{NO} 3) 3 \mathrm{i} 9 \mathrm{H} 2 \mathrm{O}$ in $250-500 \mathrm{~mL}$ of water (try to keep volume to a minimum).

Label: Solution 4

7.9 Add Solution 4 to Solution 1. Maintain at 35 to $40^{\circ} \mathrm{C}$.

7.10 Add indicated amounts of each remaining chemical to Solution 1. Maintain at 35 to $40^{\circ} \mathrm{C}$.

7.11 Slowly add $610 \mathrm{~g}$ of $50 \mathrm{wt} \% \mathrm{NaOH}$ to Solution 1, keeping the temperature between 35 and $40^{\circ} \mathrm{C}$. This step should be done with continuous agitation in a hood.

7.12 Measure $\mathrm{pH}$, adjust to $\sim 10.5$ (if already $>10.5$, take no action).

7.13 Allow solution 1 to settle (without agitation) for 30 to 60 minutes. Take a small aliquot $(-3 \mathrm{~mL})$ of filtrate and add a fraction of a drop of $50 \%$ $\mathrm{NaOH}$. If a precipitate forms, notify the researcher.

7.14 Re-agitate solution for $1 \mathrm{hr}$ and sample slurry as follows:

$4 \mathrm{~mL}$ slurry for solids concentration.

$25 \mathrm{~mL}$ slurry for analyses (to be defined later).

$20 \mathrm{~mL}$ slurry retain,

7.15 Transfer slurry to a $4 \mathrm{~L}$ beaker and allow to settle without agitation for at least two days.

7.16 Determine wt \% insoluble solids in the $4 \mathrm{~mL}$ sample.

\begin{tabular}{|l|c|}
\hline & Weight (g) \\
\hline Filter Paper & 0.0914 \\
\hline Volume of sludge & $4.00 \mathrm{~mL}$ \\
\hline Dried filter paper \& sludge & 0.4170 \\
\hline wt of dried sludge & 0.3256 \\
\hline Solids concentration & $81.4 \mathrm{~g} / \mathrm{L}$ \\
\hline Slurry wt of $10 \mathrm{~mL}$ sample & 12.15 \\
\hline Slurry density & $1.215 \mathrm{~d} / \mathrm{mL}:$ \\
\hline wt \% solids & 6.70 \\
\hline
\end{tabular}


L. O. Dworjanyn $\quad$ WSRC-RP-99-00428, Appendix B $\quad$ Page 36 of 67

7.16.1 Weigh a filter paper.

7.16,2 Agitate the $4.00 \mathrm{~mL}$ slurry sample and pour out to filter. Rinse the sample bottle twice with distilled water and add to filter.

7.16,3 Wash filtered sample with water. Discard wash water.

7.16,4 Dry sample overnight at $\sim 60^{\circ} \mathrm{C}$.

$7.16,5$ Weigh dried filter paper.

7.16.6 Save dry solids for analyses.

7.17 After two days settling sample clear solution as follows:

$25 \mathrm{~mL}$ Retain sample.

$25 \mathrm{~mL}$ Sample for analyses.

Sample for density measurement.

7.17 Measure and record the density of the clear solution:

1.215 $\mathrm{g} / \mathrm{mL}$

7.18 Store and label: Simulated Caustiv Tank 15H Sludge without Mercury or Silver.

7.19 Submit filtrate sample and sludge sample to ADS for researcher defined analyses.

7.20 Allow sludge to sit and settle and await instructions from researcher.

\subsection{Analysis}

8.1. Submit a filtrate sample for: Titration (free hydroxide, aluminum)

IC (nitrate, nitrite)

ICP-ES (scan - provide ADS analyst with a list of possible metals)

8.2. Submit a sludge sample for: ICP-ES (scan - provide ADS analyst with a list of possible metals)

\subsection{Labeling}

9.0.1 Label Sample: Tante 157 Sludge Solidi 


\section{Appendix C \\ Mercury Fulminate Preparation Procedure \\ Extract from Bill Wilmarth (Ref. 6)}

4.4.1. To a pre-weighed glass test tube, add $70 \mathrm{mg}$ of elemental mercury.

4.4.2. Add $500 \lambda$ of concentrated nitric acid, slowly heat the test tube using a heating mantle.

4.4.3. The mercury will dissolve and the solution will turn green and allow to cool.

Note: Next step entails combining two incompatible materials. Caution should be used. The mixture should be treated as though it will explode.

4.4.4. Place $500 \lambda$ of ethyl alcohol in a second test tube. Carefully transfer the contents of the first test tube into the second tube. The addition should be done in a dropwise fashion.

4.4.5. Red and/or brown fumes will be generated.

4.4.6. After $30 \mathrm{~min}$, the fumes will turn white. Wait $10 \mathrm{~min}$ and add $1000 \lambda$ of distilled, de-ionized water.

4.4.7. Crystals will form. Decant the supernate into a $30 \mathrm{~mL}$ glass vial and label appropriately.

4.4.8. Wash (add and decant) the crystal with $5 \mathrm{~mL}$ of distilled, de-ionized water and add the decanted liquid to the $25 \mathrm{~mL}$ glass vial. Perform three times.

4.4.9. Dry the fulminate at room temperature for two hours and weigh the test tube. Record quantity in the Inventory (section 4.10 of this procedure). After obtaining weight, re-wet crystals prior to storage. 
L. O. Dworjanyn WSRC-RP-99-00428, Appendix D Page 40 of 67 SOUTHWEST RESEARCH INSTITUTE

6220 CULEBRAROAO - POST OFFICE DRAWER 28510 - SAN ANTONIO. TEXAS. USA 78228.0510 - (210) 684.5111 - TELEX 244846

July 1998

A Preliminary Proposal For:

Explosive Sensitivity Assessment of Dry Sludge

By

Walt Gray

Dr. Robert White

Gene Jones

Prepared for:

Westinghouse Savannah River Company

Savannah River Technology Center

Building 735-IIA

Aiken, SC 29808

Approved:

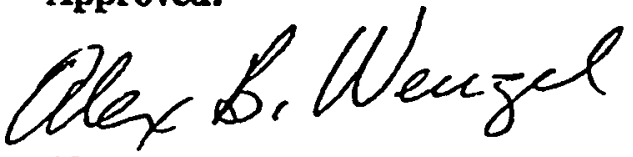

Alex B. Wenzel

Director

Department of Fire Technology

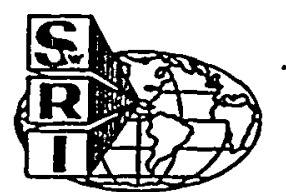




\subsection{INTRODUCTION}

The Westinghouse Savannah River Company (WSRC) has expressed a need to assess the level of hazard posed by a potentially explosive High Level Waste (HLW) sludge residue currently stored in tanks at the Savannah River facility. Normally, the sludge is wet, being kept in a caustic solution. Recently, however, inspections have revealed that some of the sludge has dried out in some of the tanks. Due to the presence of mercury, WSRC is concerned that the mercury-based explosives may have formed, especially mercury fulminate explosive. To assist WSRC in their hazard assessment, SwRI was contacted about conducting explosive sensitivity tests on a simulated dry sludge/mercury fulminate mixture. The test results will be used by Westinghouse in assessing the explosive hazard potential of the HLW dry sludge residue.

As part of the proposed project, SwRI will synthesize small quantities of mercury fulminate and mix them in varying proportions with the sludge simulant supplied by WSRC. The sludge simulant will approximate the chemical composition of the HLW dry sludge, but will not contain any of the radioactive components. SwRI will subject the resulting mixtures to a series of stimuli (impact, friction, heat, shock, clectrostatic, etc.) and gather data on their relative sensitivity. The data will then be forwarded to Westinghouse. Thus, the objective of this effort is to conduct sensitivity testing on the simulated dry sludge and mercury fulminate mixture and compare the results to those values determined for explosive of known sensitivity. All tests were conducted using apparatuses of SwRI design.

\subsection{DESCRIPTION OF SENSITIVITY TEST APPARATUSES AND PROCEDURES}

Six different test procedures may be utilized during this program to determine the sensitivity level of the dry sludge. These tests include: (1) impact sensitivity, (2) sliding friction sensitivity, (3) minimum electrostatic ignition energy, (4) thermal stability, (5) small-scale buming, and (6) gap test. To conduct these tests, four key test apparatuses of SwRI design were utilized, (1) Impact Sensitivity Apparatus, (2) Sliding Friction Sensitivity Apparatus, (3) Electrostatic Sensitivity Apparatus, and (4) Thermal Stability Apparatus.

\section{A. Impact Sensitivity}

The SwRI Impact Sensitivity Test Apparatus is a modified version of the Explosives Research Laboratory (ERL) Impact Test Apparatus. The apparatus consists of an anvil, striker, slide and weight (Figure 1). The test is conducted by dropping various weights from a known height upon a 0.030 gram sample placed on a single layer of 400 grit sandpaper. The sample and sandpaper are located between the anvil and striker. The result is considered positive if either an audible report, flame, smoke or combustion products are detected on any of ten trials at a particular height. If a positive result occurs, the weight is lowered to a height of one-half the original height. If no positive results are obtained, the weight is raised one-half the distance to the previous height at which a positive result was obtained. This up and down procedure is repeated until a maximum height is found at which no positive results are obtained for ten trials. If no positive reactions are observed at the maximum drop height ( 34.5 inches), additional weight is added and the process repeated. For ease of comparison with other test apparatuses, a threshold energy value (TEV) is reported. The TEV is calculated by multiplying the lowest drop weight and height at which a positive reaction is obtained. 


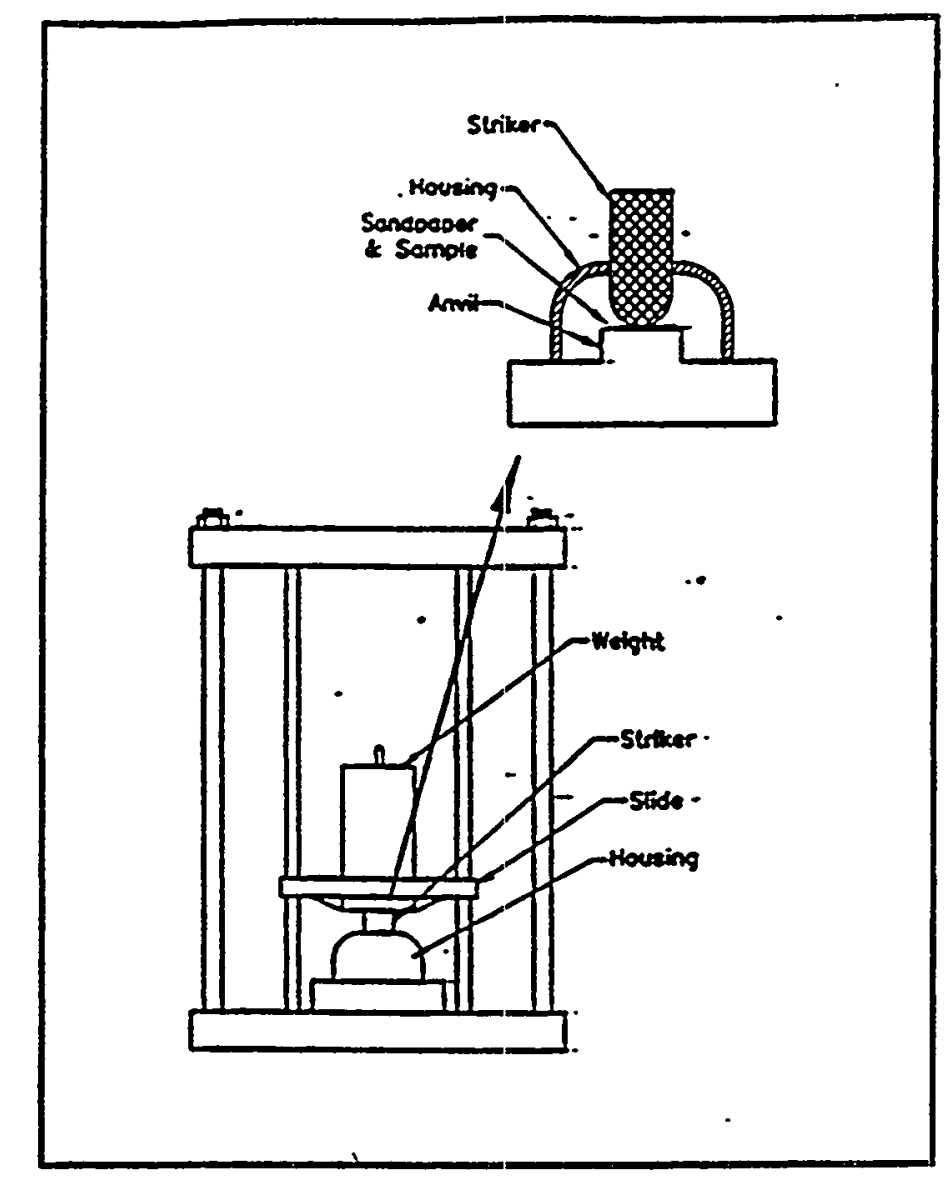

Figure 1. Schematic of SwRI Impact Sensitivity Apparatus.

To begin the test, the weight and slide are raised to the desired height and secured with a safety latch. The drop height is measured from the bottom of the slide to the top of the plunger. Next, the anvil and striker are washed with acetone and allowed to dry. The anvil is then placed on the apparatus, and a single layer of sandpaper is placed on the top of the anvil. Using a calibrated balance, 0.030 gram of the sample is weighed and placed on the sandpaper. The striker housing is then placed in the machined groove surrounding the anvil. The striker is carefully inserted into the housing and gently lowered onto the sample. The safety latch holding the weight is then removed and a quick-release pin inserted. Without disturbing the quick-release pin, a lanyard is then attached to the pin.

From a protected location, the operator pulls the lanyard, releases the weight, and observes the apparatus for a positive reaction. After the test, the slide and weight are raised and secured with the safety latch. The housing and striker assembly are removed along with the sandpaper. The sandpaper is segregated for later disposal. The anvil and striker are then examined for deformation and replaced if necessary. The apparatus is then prepared for the next test. 


\section{B. Friction Sensitivity}

Friction sensitivity is a measure of the reaction susceptibility of the substance to a slidingtype frictional stimulus. Friction sensitivity was assessed using the SwRI Sliding Friction Apparatus, a modified version of the Allegheny Ballistics Laboratory (ABL) Friction Test Apparatus. The SwRI apparatus consists of a vertical press frame, hydraulic cylinder and controls, load cell, non-rotating wheel, sliding anvil, pendulum and weight (Figure 2). The sample is subjected to a vertical compressive force between a non-rotating wheel, and sliding anvil. A pendulum impacting on the edge of the anvil propels the anvil forward, perpendicular to the compressive force. Forward movement of the anvil creates a frictional force on the sample. A test is considered positive if one of the following results is observed:

- Visible Sparks

- Visible Flame

- Audible Explosion

- Loud Crackling Noise

- Detection of Combustion Products

The velocity of the anvil is measured by two contact switches and a frequency counter. Forward movement of the anvil closes each switch in turn. The electrical signal from the first switch starts the frequency counter and the signal from the second switch stops the counter. The velocity is then calculated by dividing the distance between switches by the time difference displayed on the frequency counter. At each value of applied vertical load, the velocity of the anvil is varied by changing the pendulum angle and weight. The non-rotating wheel and sliding anvil are fabricated from Maraging tool steel hardened to Rockwell C 58-62. The surfaces in contact are polished to a finish of 60 micro-inches, with the polishing direction being oriented perpendicular to the direction of anvil movement.

To conduct the test, the anvil and non-rotating wheel are thoroughly cleaned with acetone and allowed to dry. Using an analytical balance, approximately .025 gram of the sample is weighed and spread over the anvil in a thin uniform layer of approximately one particle thickness. The nonrotating whieel is then carefully lowered into position over the sample. The pendulum and weight are then raised to the desired height, the quick release pin inserted, and the lanyard attached. From a remote location, the hydraulic cylinder is activated and the desired vertical force applied to the nonrotating wheel and anvil (as measured by the load cell). The operator then pulls the lanyard to release the pendulum and weight, and observes for a reaction. The applied load, anvil velocity and observation of reaction are then recorded. The hydraulic cylinder is deactivated, the anvil removed, . and preparations made for the next test.

Typically, a single threshold sensitivity value does not result from this test. Positive and negative results are reported for a range of vertical loads and anvil velocities. As shown in Figure 3 , a plot of load versus velocity usually allows for determination of reaction and non-reaction spaces. Plots of results from known energetic materials are then compared with a similar plot for the material being tested. 


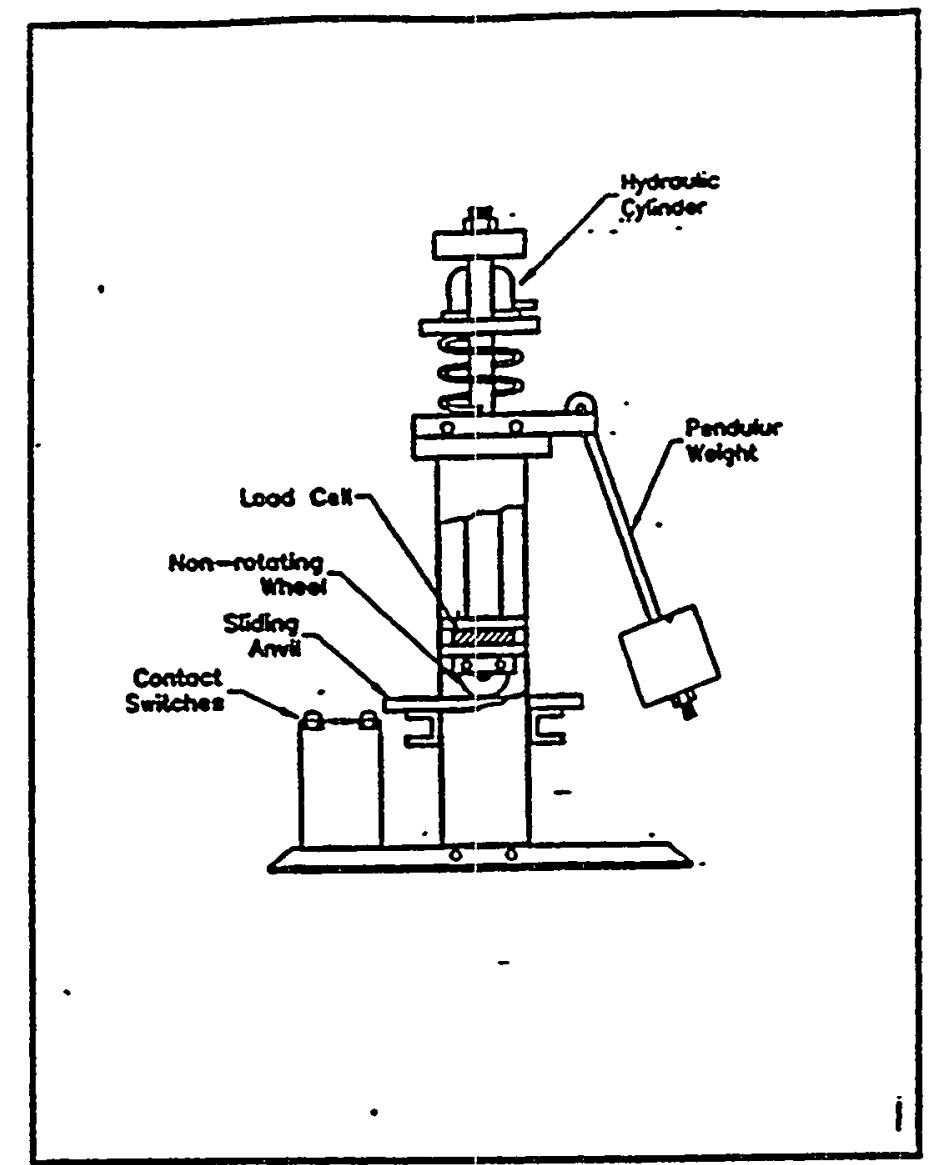

Figure 2. Schematic of SwRI

Friction Sensitivity Apparatus.

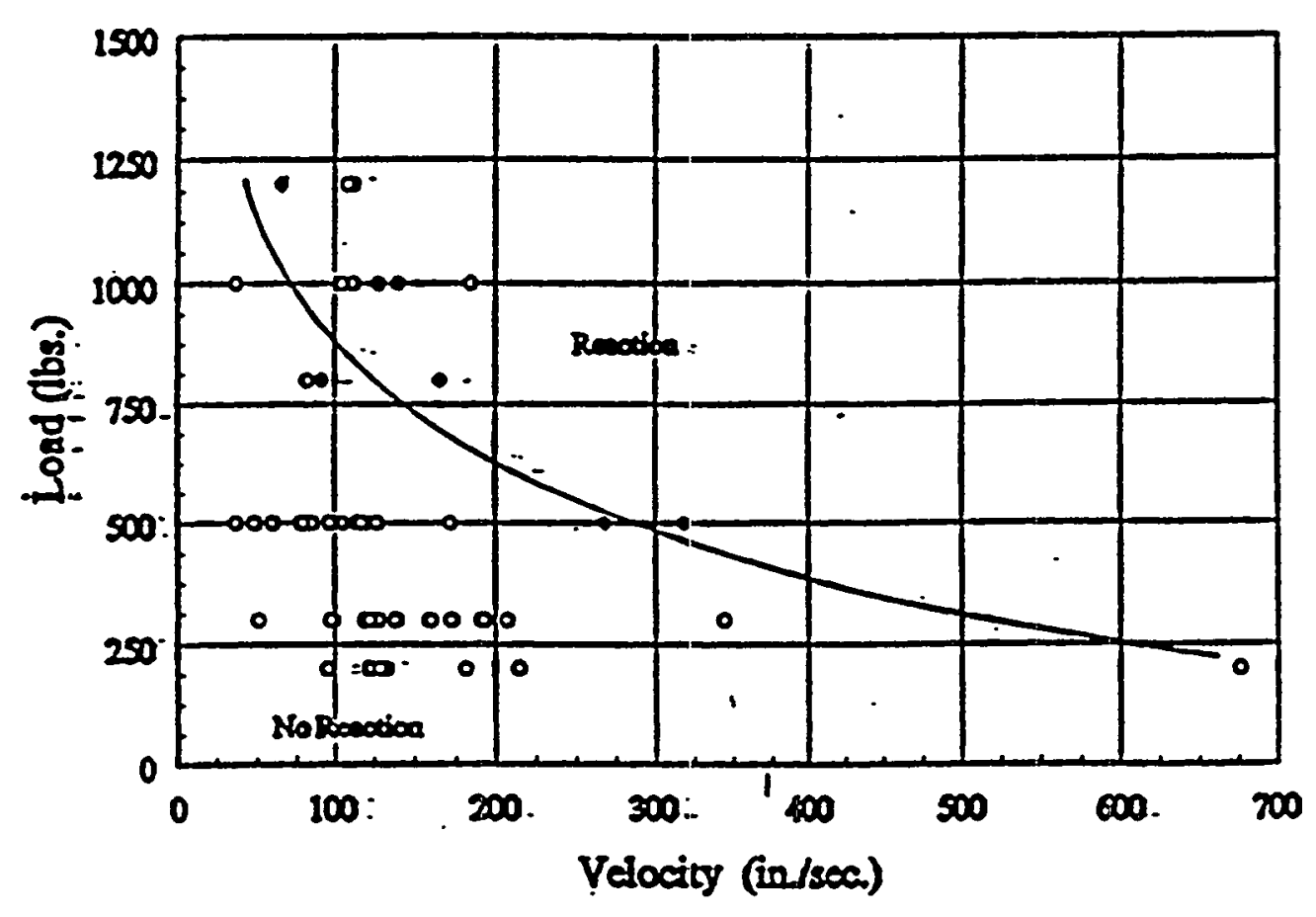

Figure 3. As Shown in the Diagram Above, the Sliding Friction Test Results in the Definition of Reaction and Non-reaction Areas for

Various Vertical Loads and Anvil Velocities. 


\section{Thermal Stability}

Thermal Stability determines the potential for substances to detonate, ignite, decompose or change configuration when subjected to long periods of sustained heat as might be encountered during storage. The test is divided into two parts. In the first part, samples are placed in an explosion-proof oven and maintained at $75^{\circ} \mathrm{C}$ for 48 hours. The oven and sample temperatures are continuously monitored with the oven temperature controlled throughout the test period. Observations are made as to whether the sample explodes, ignites (as indicated by a rise in sample temperature) and/or undergoes a change in configuration such as weight loss or color change. A sample of approximately 50 grams is placed in an open $150 \mathrm{cc}$ Pyrex beaker and allowed to dry in a desiccator for 12 hours. The beaker is then removed from the desiccator and weighed. A thermocouple is inserted into the sample with the sensor tip located approximately half-way between the bottom of the beaker and the free surface of the sample. The assembly is then placed into an explosion-proof oven, and the thermocouple connected. A second thermocouple is placed in the oven to monitor the oven air temperature. A PC-based data acquisition system records both the sample and oven air temperature for the entire 48-hour period. A test is considered positive if an explosion, ignition, color change, or a weight loss in excess of 20 percent occurs.

If a positive result is obtained in the first part, then the second part is conducted. Approximately 10 grams of sample and 10 grams of sodium chloride (salt) are placed in separate test tubes. Thermocouples are inserted into the test tubes such that the sensor is imbedded half-way into the compounds. The assemblies are then placed in a desiccator for 12 hours. The assemblies are removed and the test tubes sealed with rubber stoppers or other suitable devices and weighed. They are then placed in the oven along with a third thermocouple to monitor oven air temperature. The oven is set to maintain $75^{\circ} \mathrm{C}$, and the temperatures recorded for 48 hours. Again, a PC-based data acquisition system is used to record the three temperatures. After the test, the test tube assemblies are recovered and weighed. A test is considered positive if an explosion, ignition or temperature difference between the two compounds of $3^{\circ} \mathrm{C}$ or greater is observed.

\section{Electrostatic Sensitivity Test}

The electrostatic sensitivity test determines the sensitivity of a sample to electrical discharge. The test measures the minimum amount of spark energy required to ignite the sample. A small amount of the material is placed on a grounded anode, and the electrode (which is charged with high voltage through a series capacitor circuit) is lowered to the anode until a predetermined gap is achieved. The electrical system is energized, creating a spark between the anode and cathode which continues until the capacitor is discharged. The energy is assumed to be equal to $0.5 \mathrm{CV}^{2}$, where $V$ is the applied voltage and $C$ is the capacitance. The energy level (charge on capacitor) is increased or decreased depending on the results until the minimum energy required to produce ignition is found. Ignition of the sample is indicated by a visual or audible explosion, smoke, flame or detection of combustion products. The results are then compared to various reference materials and a relative sensitivity value assigned.

The SwRI Electrostatic Sensitivity Test Apparatus is illustrated in Figure 4. It consists of a .040-in. diameter tungsten electrode, stainless steel anode sample holder (cup), variable transformer/power supply, capacitive discharge circuit and trigger. To conduct the test, the sample is preconditioned by drying at $25^{\circ} \mathrm{C}$ for 12 hours, followed by storage in a desiccator until ready for use. The anode sample.holder and electrode are then thoroughly cleaned with acetone and allowed to dry. Using an analytical balance, 0.020 gram of the sample is weighed and placed in the anode 
sample holder. The sample holder is then placed on the apparatus, and the electrode lowered until the desired gap is achieved. A clear polycarbonate plate is used to shield the operator from the apparatus. From a remote location, the electrical circuit is energized. The capacitor is then discharged and the sample observed for a reaction. Again, a positive reaction is indicated by observation of sound, flame, smoke or detection of combustion products. The data sheet is then annotated, and the apparatus prepared for the next test.

\section{E. Small-Scale Burning Test}

This test is designed to assess the response of substances to fire and determine the ease of deflagration to detonation transition of small quartities of substances when unconfined. To conduct the test, approximately 125 grams of the substince are placed in a 200 cubic centimeter plastic beaker (or other suitable holder). The sample and beaker are then placed on a bed of kerosenesoaked sawdust. Using a remotely actuated igniter, the sawdust is ignited and the substance observed for detonation or explosion. No explosion or detonation can occur in any of three tests.

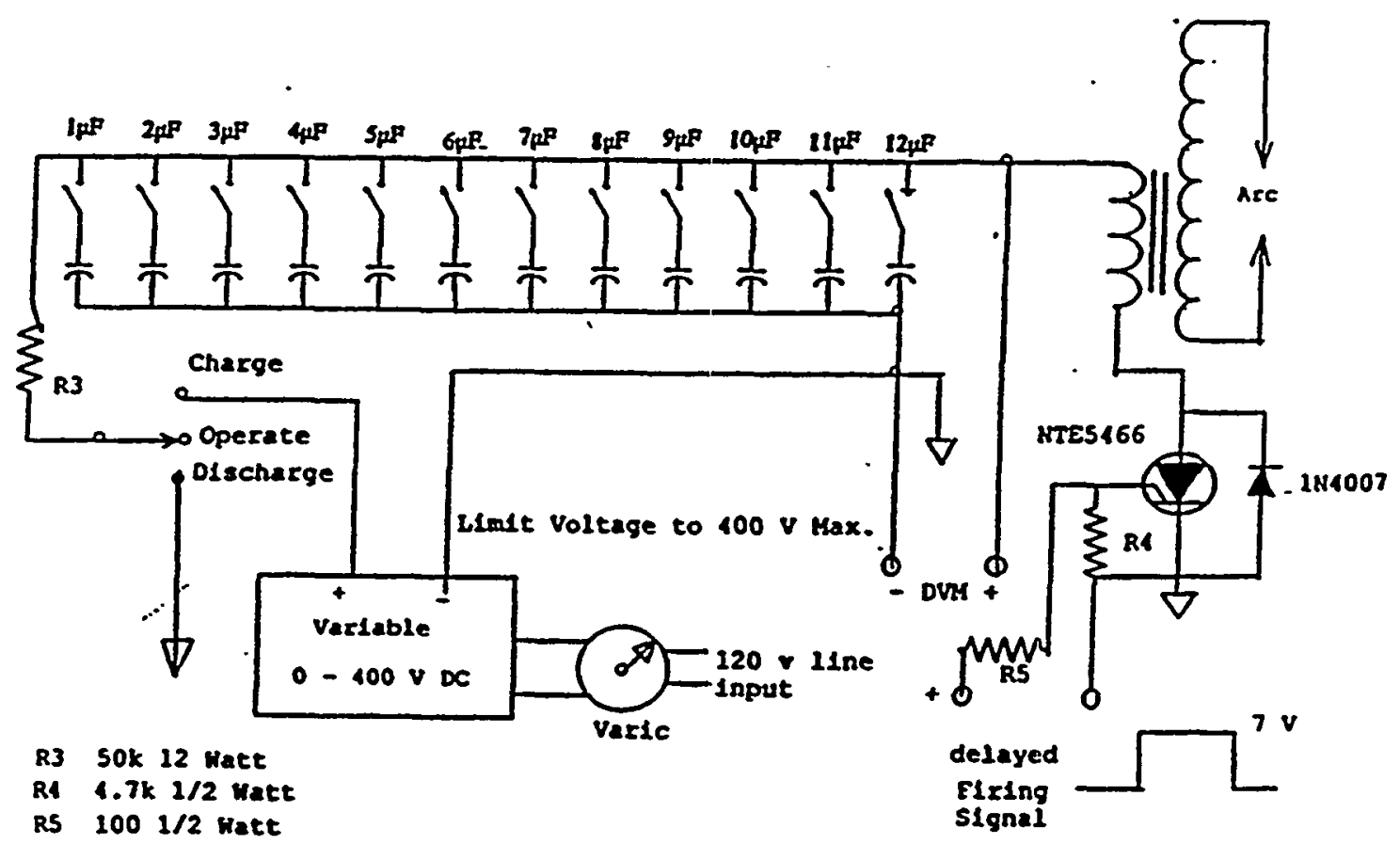

Figure 4. Schematic of Capacitive Discharge Circuit.

\section{F. Gap Test}

The apparatus for the Gap Test is showin in Figure 5. The test sample is contained in a cylinder 16 inches long, typically made from a $1 / 2$-inch diameter schedule 80 , black seamless-steel mechanical pipe. (This size pipe holds approximately 29 in. $^{3}$ of the sample). A mild steel witness plate 6-inches square and 1/8-inch in thickness is mounted at the upper end of the pipe and separated 
from it by $1 / 16$-inch thick spacers. The bottom of the pipe is closed with two layers of .003 -inch thick polyethylene sheet held in place with polyvinyl chloride electrical tape. A continuous velocity probe in then placed along one side of the steel pipe. The probe is made by inserting an axial resistance wire, with space-served insulation, into a thin aluminum tube. The aluminum tube is crimped against the axial resistance wire at the lower end to form a resistor. When crushed by the shock in the sample, the probe's resistance increases at a rate proportional to the velocity of the shock. In previous experiments, SwRI has shown the need to isolate the probe from the walls of the steel pipe. When the probe is in contact with the steel pipe, the shock wave traveling in the steel often interferes with the probe's ability to measure the slower shock traveling in the sample. Thus, the probe will be mounted on a thin strip of wood before it is inserted into the steel pipe.

The sludge sample will be loaded into the pipe and gently vibrated until no further settling is perceptible. An explosive charge (typically a pentolite booster) is placed against the lower end of the pipe so that no gap occurs between the explosive and the polyethylene sheet. The charge is initiated using an electric exploding bridge wire (EBW) detonator held in place with a cork holder. Propagation of the initial detonation is considered to have occurred if any one of the following is observed:

- The steel pipe is fragmented along its entire length;

- A hole is punched in the witness plate;

- A stable shock velocity greater than $4,900 \mathrm{ft} / \mathrm{s}$ is observed.

For a negative result, detonation propagation must not be observed on any of three consecutive tests. 


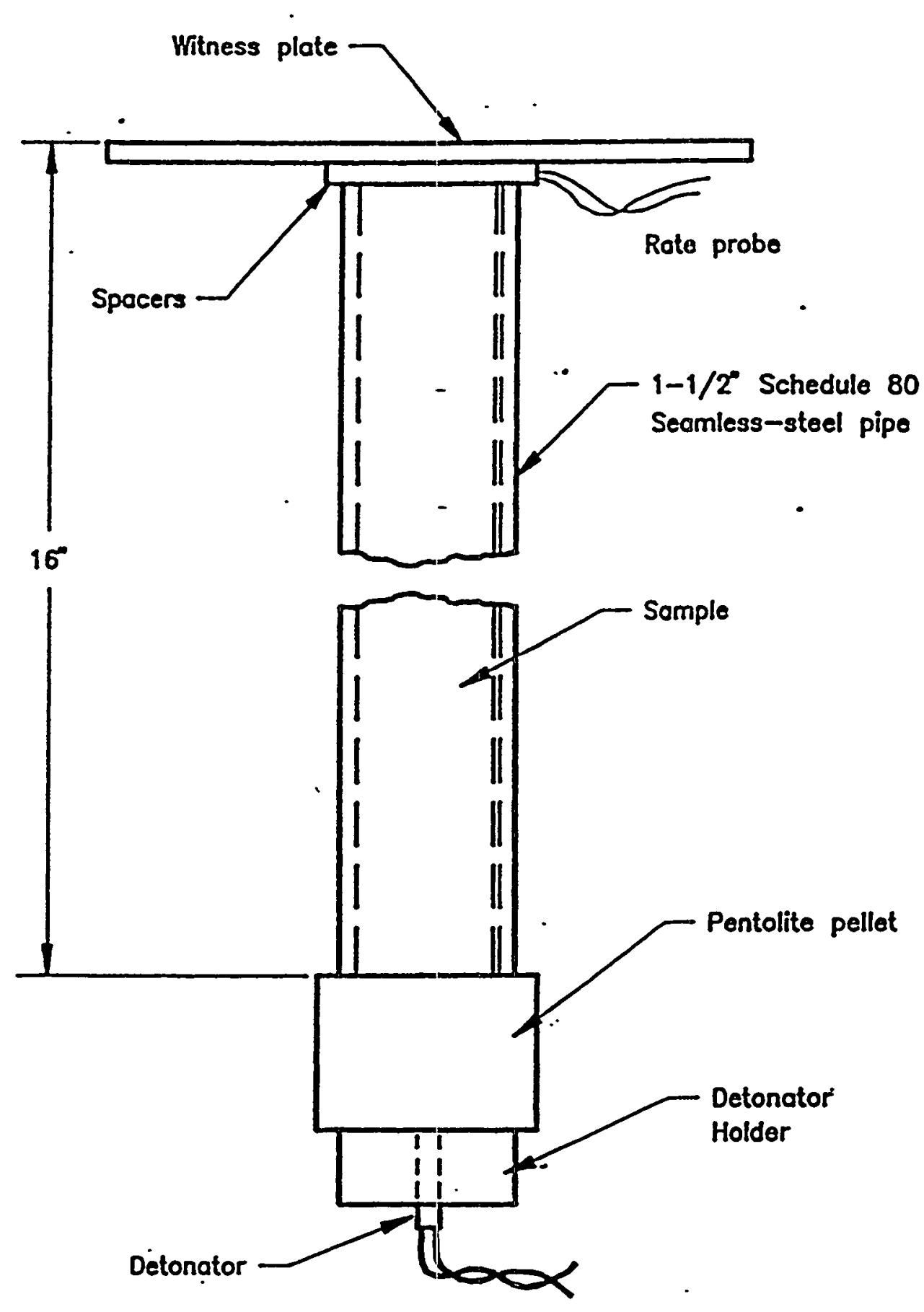

Figure 5. Apparatus for Gap Test 


\subsection{SYNTHESIS OF THE MERCURY FULMINATE}

The mercury fulminated will be prepared in small, laboratory quantities. Synthesis will be conducted in a remote facility approved for temporary storage of up to $50 \mathrm{lbs}$ of explosive. Preparation will be conducted only under a fume hood fitted with approved safety shields and electrostatic protection. The intent is to prepare only the quantity of mercury fulminate required for each upcoming test series. For the impact, electrostatic and friction tests, only milligram quantities will be required. Thus, these quantities will be prepared first. The larger quantities required for the thermal stability, small-scale burn, and gap tests will be prepared in stages of no more than 10 grams. For safety reasons the mercury fulminate crystals will be stored wet (i.e., under a cover of water or in a water solution). To facilitate safe mixing of the simulated sludge and mercury fulminate, a water solution of the sludge will be prepared first, followed by introduction of the required weight of mercury fulminate solution. The resulting mix will then be slowly dried under low heat and stored in a desiccator until ready for testing. ${ }^{*}$

To prepare the mercury fulminate, 5 grams of mercury will be added to $55 \mathrm{ml}$ of concentrated nitric acid. The mixture will then be allowed to stand without shaking until the mercury has gone into solution. The solution will then be slowly heated to $55-60^{\circ} \mathrm{C}$ by means of a water bath and allowed to stand ovemight. The acid liquid is then poured into $50 \mathrm{ml}$ of 90 percent ethyl alcohol contained in a $500 \mathrm{ml}$ beaker. Red and/or brown fumes will be quickly produced. After approximately thirty minutes, the fumes will turn white, indicating that the reaction is nearing completion. After an additional 10 minutes, $30 \mathrm{ml}$ of water is added to the solution. The resulting liquid is then decanted, and more water is added. This process is repeated until a pH of 7 is achieved. The mercury fulminate crystals are then filtered out and washed several times with alcohol. The crystals are placed on a filter paper and the remaining alcohol is allowed to evaporate. The crystals are then stored under water.

The purity of the mercury fulminate will be verified using a sodium thiosulfate and potassium iodide titration. The sludge/mercury fulminate mixture will be analyzed using Fourier Transform Infrared Spectroscopy (FTIR) and/or spectroscopy probe. However, difficulties are anticipated due to potential interference from other metals present in the sludge.

\subsection{REPORTING}

At the conclusion of each test series, the results will be reported by telephone and telefax to the designated Westinghouse representative. Within 30 days following completion of all explosive sensitivity testing, SwRI will prepare and submit a written final report to Westinghouse. The report will describe the test methods used, significant observations, results obtained and conclusions.

\subsection{SwRI AND WESTINGHOUSE SUPPLIED ITEMS}

SwRI will provide all equipment, personnel, and materials necessary to conduct the tests described herein. In addition, SwRI will provide the raw materials and synthesize all required quantities of mercury fulminate. Westinghouse will provide all required quantities of the simulated HLW sludge in a form ready to be tested, as well as covering the cost of shipping it to San Antonio. 


\subsection{PRICE SCHEDULE}

Shown in Table 1 is a budgetary cost estimate for the various tests and activities anticipated. A total cost will be submitted once a definite scope of work has been decided upon.

Table 1. Budgetary Cost Estimates

\begin{tabular}{|l|c|c|}
\hline \multicolumn{1}{|c|}{ Test/Task } & Set-up Charge & $\begin{array}{c}\text { Price per } \\
\text { sample/batch }\end{array}$ \\
\hline \hline Impact Sensitivity Test & $\$ 300$ & $\$ 900$ \\
\hline Friction Sensitivity Test & $\$ 550$ & $\$ 1,400$ \\
\hline Thermal Stability & $\$ 900$ & $\$ 350$ \\
\hline Small-scale Buming Test & NA & $\$ 300$ \\
\hline Electrostatic Sensitivity Test & $\$ 200$ & $\$ 350$ \\
\hline Gap Test & $\mathbb{N A}$ & $\$ 9,000$ \\
\hline Synthesis of Mercury Fulminate & $\$ 14,100$ & $\$ 3,000$ \\
\hline Analysis of Sludge/M.F. mix & $\$ 5,000$ & $\$ 800$ \\
\hline
\end{tabular}

\subsection{PROGRAM PERSONNEL 、}

Walt Gray (MSME,MBA) will serve as the l'roject Manager, responsible for administrative and fiscal management of the program. He will also have responsibility for conducting and supervising the explosive sensitivity tests. Mr. Gray has served in this capacity on numerous successful programs, including testing of explosive proof equipment, evaluation of detonation/flame arresters used in flammable vapor environments, design and testing of solid propellant devices, and flow and combustion visualization of liquid propellant guns. He recently completed a program which examined the explosive sensitivity of demilitarized explosive residuals and compared the results to several known explosives. He designed many of apparatuses required. He has also served as test engineer on numerous programs and is familiar with test instrumentation, data acquisition, and laboratory practices necessary to conduct the tests described herein.

Robert White (Ph.D. Aero. Eng.) will provide technical advice and guidance to the program. Over the past 18 years at SwRI, Dr. White has conducted a variety of experimental programs involving energetic materials and processes including dust and gas explosions, explosive sensitivity evaluation, characterization of blast effects, flammability and detonability of gas mixtures, as well as hazards posed by highly exothermic chemical reactions and runaway. polymerization. Herecently completed a program aimed at evaluating the flammability/explosibility characteristics of metal and metal-alloy powders.

Detailed professional record sheets of these individuals as well as other technical support personnel are provided in Appendix A. 


\section{Chilworth Technology, Inc}

Princeton Corporate Plaza

11 Deer Park Drive

Monmouth Junction,

New Jersey 08852-1923

Telephone: (732)274-0900

Facsimile: (732)274-1371

email: safety@chilworth.com

http://www.chilworth.com

\author{
Appendix E. \\ Chilworth Technology Proposal for Dry Sludge Testing
}

June 11, 1998

Mr. Lee Dworjanyn

Advisory Scientist

Savannah River Technology Center

Westinghouse

Savannah River Company

Aiken, SC 29808

Dear Lee;

Since our meeting here at Chilworth last Thursday, I have thought about certain parts of your problem and have collected the references that I promised you.

The references are enclosed along with my thoughts.

I have outlined below a testing program that will identify some potential hazards associated with the removal of the tank sludge. It is based upon having a representative sample to test. In addition, I have attached a cost estimate for completing this test program.

Should no such sample be available, we can, as you suggested, prepare "mock" samples and subject them to the same testing program. Chilworth can advise on the required properties of the mock samples from a testing point of view.

I have found a literature method for preparation of mercury fulminate (attached): This might be a good candidate for the explosive component of the mock sample since (1) the prep is simple and can be carried out in our lab and (2) you have reason to believe this a likely sludge component. A literature search will probably turn up preps for many of the other possible explosive components you propose.

The cost to prepare "mock" samples cannot be worked out until we have a much better idea of what the sample compositions will be. 
If you recall in your visit we discussed the concept of "spiking" a generic sludge matrix with a known explosive that is both shock sensitive and capable of propagating an explosion. This explosive might be the compound you deem the most probable explosive component of the tank sludge or a well-known material such as RDX (Trimethylenetrinitramine). The spiking level can be varied from a few to several hundred ppm. These samples can be tested for shock and friction sensitivity and explosion propagation. The BAM fallhammer and BAM friction tests are available and I've included a cost for each below.

The reference by Yoshida (enclosed) describes a DSC method to assess shock sensitivity and explosion propagation on small $(\mathrm{mg})$ samplè. By this method, a judgment is made as to whether the test sample is more or less shock sensitive than mdinitrobenzene (a well-known literature reference). Also by this method, a judgment is made as to whether or not the sample can propagate an explosion. The DSC method offers several advantages: (1) small sample size (2) samples can easily be loaded in a glovebox (3) many samples can be run in one day using an autosampler on the DSC so that the method is relatively inexpensive to use and (4) the Yoshida correlation can be used. This method can be applied to your mock samples with these advantages.

Once an appropriate range of concentrations (spiking levels) is determined by DSC, the next step is scale-up: Adiabatic calorimetry should be performed on these same concentrations on a large enough scale to bring the phi factor down to around 1.1 and thereby reproduce the phi factor of the actual tank. First, 20 gram samples would be tested in the Carius tube test. Depending upon these results, the sample size might be increased to between 0.5 and $1 \mathrm{~kg}$ and tested in the Adiabatic Pressure Dewar calorimeter. The onset temperature for thermal nunaway is determined this way. Also determined are the rates of heat and pressure generation and adiabatic temperature rise (per gram of test material) associated with the thermal runaway.

After assessing the potential for a shock sensitive, friction sensitive, heat sensitive sludge, we can look at best ways to remove the sludge from the tank. Redissolving it into a suitable solvent might generate substantial heat: $\mathrm{RCl}$ calorimetry can determine this.

The attached quote then includes costs for the following tests:

BAM fallhamer and friction tests

Differential Scanning Calorimetry (DSC)

Carius Tube Test

Adiabatic Pressure Dewar Calorimetry (ADC)

Reaction Calorimetry $(\mathrm{RC} 1)$

I can quote costs to conduct a literature search or prepare samples only after I know more about the samples and/or sludge components. 
Should you decide upon a large test matrix with many samples, I am sure that we can provide a discount on these costs.

I enjoyed meeting you and hope that we can be of service.

Best Regards,

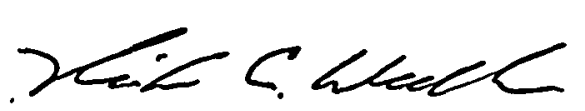

Richard Wedlich

Sr. Process Safety Specialist

For and on behalf of Chilworth Technology, Inc. 


\section{Chilworth Technology, Inc}

Princeton Corporate Plaza

11 Deer Park Drive

Monmouth Junction,

New Jersey 08852-1923

Telephone: (732)274-0900

Facsimile: (732)274-1371

email: safety@chilworth.com

http:/hwww.chilworth.com

June 12, 1998

Mr. Lee Dworjanyn

Advisory Scientist

Savannah River Technology Center

Westinghouse

Savannah River Company

Aiken, SC 29808

CHEMICAL TESTING

Impact Sensitivity Test - BAM Fall Hammer Test

Cost $\$ \$ 1550.00$ per sample

Chilworth Technology, Inc., performs impact sensitivity testing using the BAM Fall Hammer apparatus developed by the German Federal Institute for Testing Materials (BAM). Impact energy is imparted to a $40 \mathrm{~mm}^{3}$ sample by means of a falling weight. The limiting impact energy is determined as the lowest energy at which a flash, flame, or explosion is observed. The test is used to assess the sensitivity of the test material to drop-weight impact. The BAM Fallhammer test is a part of UN Test Series 3 which is used to assess the ignition sensitivity of suspected explosive materials. As many as 54 trials may be performed and therefore approximately 3 cubic centimeters (cc) of sample may be required.

Friction Sensitivity Test - BAM Friction Test

\section{Cost $\$ 1550.00$ per sample}

Chilworth Technology, Inc., performs friction sensitivity testing using the BAM Friction apparatus developed by the German Federal Institute for Testing and Materials (BAM). The test is used to measure the sensitivity of test materials to frictional stimuli. The test is a part of UN Test Series 3 which is sued to assess the ignition sensitivity of suspected explosive materials. A $10 \mathrm{~mm}^{3}$ sample is spread on a porcelain plate and the plate is then dragged under a weighted porcelain peg. The force on the peg is varied and the limiting friction load is determined as the lowest force for which a flash, flame, or explosion is observed. As naany as 60 trials may be performed, and therefore approximately 1 cubic centimeter (cc) of sample may be required. 


\section{Differential Scanning Calorimetry}

\section{Cost $\$ 550.00$ per sample}

Chilworth Technology, Inc., uses differential scanning calorimetry (DSC) or Accelerating Rate Calorimetry (ARC) to determine the quantity of heat evolved during a thermally-initiated decomposition. This method classifies materials as self-heating, explosive, or detonable based on decomposition energy.

\section{Carius Tube Test - Enclosed}

\section{Cost $\$ 1650.00$ per sample}

The Carius Tube Test is used to determine the onset temperature for decomposition of individual or commingled reactants and the rate of gas evolution from such decomposition. Chilworth Technology, Inc., performs the test by sealing 10-20 grams of sample into a glass Carius tube fitted with a reentrant thermocouple and a pressure transducer. The tube is then heated at a rate of $0.5^{\circ} \mathrm{C} / \mathrm{min}$ per minute up to $400{ }^{\circ} \mathrm{C}$ or a set pressure cutoff. Temperature and pressure are monitored continuously and the decomposition onset temperature is determined by analysis of the resulting data. After identifying the decomposition onset temperature, the rate of gas evolution is determined by carrying out the test isothermally. Isothermal testing can also be used to determine induction time effects and safe storage times and temperatures.

\section{Dewar Test}

\section{Cost \\ $\$ 2600.00$ per sample}

The Dewar Test employs an adiabatic pressure dewar to obtain data characteristic of thermal runaway reactions. Because the test employs a large sample size (as much as $800 \mathrm{~mL}$ ) and a light-weight, low-heat capacity dewar vessel, the phi factor for the system can be reduced as low as 1.05 . The kinetic and thermodynamic data required for determining the pressure relief requirements under thermal runaway conditions are obtained by this test method.

\section{Reaction Calorimetry Test}

\section{Cost $\$ 2900.00$ per sample}

Reaction Calorimetry is used to characterize the thermodynamic and kinetic properties of the reaction process under realistic and upset process conditions and to optimize conditions. The RC1 instrument allows the experimenter to simulate plant conditions and to simultaneously determine actual heat generation data. The cooling requirements on the plant scale are calculated from these data. These data also allow the assessment of the degree of accumulated, non-reacted material as a function of process design parameters such as temperature, feed rate, catalyst concentration, etc. 
The prices for the above tests are quoted on a per sample basis. The prices include all testing, setup costs, and sample preparation. Prices also include a comprehensive report for each sample, which contains the test results, a description of the test methods, and a discussion of the results.

Test results are made available within fifteen (15) business days from receipt of samples. We are also pleased to offer fast turnaround service. As a part of such service, test results are made available within five (5) business days from receipt of samples for an additional 35 percent charge per test per sample.

\section{NOTES}

Quotation valid for 90 days.

Consumables are charged extra at cost.

Results available within 30 working days.

Client to be charged all shipping at cost.

Client to supply material for testing.

Surplus material after testing will be disposed of in line with current environmental guidelines or returned to client. In either case, a fixed cost of $\$ 50.00 /$ per sample will be charged. Particularly Hazardous Substances - Additional charges may be applied for the testing of "particularly hazardous substances", including certain carcinogens, reproductive toxins, and substances with a high degree of acute toxicity (per 29 CFR 1910.1450).

Additional copies of the final report can be provided at a cost of $\$ 50.00$ per copy. 

L. O. Dworjanyn
WSR'C-RP-99-00428, Appendix F
Page 57 of 67

Worldwide Standards Plus Issue 99-02

Reproduced from Information Handling Services $(r)$

Appendix F.

Fri Mar 12 14:28:02 1999

ASTM E680 Impact Hammer Tester used by Chilworth Technology

ASTM E680 Standard Test Method for Drop Weight Impact Sensitivity of Solid-Phase Hazardous Materials $\mathrm{R}(1992)$

Organization Acronym: ASTM

Title (English): Standard Test Method for Drop Weight Impact

Sensitivity of Solid-Phase Hazardous Materials

Document Type: $S$

$\mathrm{R}(1992)$

Geographic Source: US;01

Number of Pages: 7

Abstract (English): 1.1 This test method 2,3 is designed to determine the relative sensitivities of solid-phase hazardous materials to drop weight impact stimulus. For liquid-phase materials refer to Method-D2540.

1.2 This standard may involve hazardous materials, operations, and equipment. This standard does not purport to address all of the safety problems associated with its use. It is the responsibility of whoever uses this standard to consult and establish appropriate safety and health practices and determine the applicability of

IHS Product Codes: 418 regulatory limitations prior to use.

IHS Descriptor (French): ESSAI AU CHOC; Matiere Dangereuse MATIERE DANGEREUSE; Essai au Choc

IHS Descriptor (German): GEFAEHRLICHES MATERIAL; Schlagversuch SCHLAGVERSUCH; Gefaehrliches Material

IHS Descriptor (Spanish): MATERIALES PELIGROSOS; Prueba de Impacto PRUEBA DE IMPACTO; Materiales Peligrosos

IHS Descriptor (English): HAZARDOUS MATERIALS; Impact Testing IMPACT TESTING; Hazardous Materials

Title: Standard Test Method for Drop Weight Impact Sensitivity of Solid-Phase Hazardous Materials $\mathrm{R}(1992)$

Street Address: 100 Barr Harbor Dr

City: West Conshohocken

State: PA

Zip Code: 19428-2959

Country: United States

Phone: $610832-9500$

Fax Number: 610 832-9555

Organization: American Society For Testing \& Materials

Document Number: E680

Publication Date: 1979-00-00

Image Disc: ST1604

Document Number (Parsed): E680

Document Number Fragments: E 680

Document Number (Stripped): E680

Organization Name Fragments: American Society For Testing \& Materials 


\title{
Standard Test Method for Drop Weight Impact Sensitivity Of Solid-Phase Hazardous Materials ${ }^{1}$
}

\begin{abstract}
This standard is lssued under the fixed designation E 680: the number immediately following the designation indicules the year of original adoption or, in the case of revision, the year of last revision. A number in parentheses indicates the year of last reapproval. A superscript epsiton (Q) indicates an editorial change since the last revision or reapproval.
\end{abstract}

\section{INTRODUCTION}

This method is one of several methods being developed by ASTM Committee E-27 on Hazard Potential of Chemicals. This method is to be used in conjunction with other tests to characterize the hazard potential of chemicals.

\section{Scope}

1.1 This test method ${ }^{2.3}$ is designed to determine the relative sensitivities of solid-phase hazardous materials to drop weight impact stimulus. For liquid-phase materials refer to Method D 2540.

1.2 This standard may involve hazardous materials, operations, and equipment. This standard does not purport to address all of the safety problems associated with its wse. It is the responsibility of whoever uses this standard to consult and establish appropriate safety and health practices and determine the applicability of regulatory limitations prior to use.

\section{Referenced Documents}

\subsection{ASTM Standards:}

D2540 Test Method for Drop Weight Sensitivity of Liquid Monopropellants ${ }^{4}$

\section{Summary of Method}

3.1 Restrictions are placed upon the ranges of impact tool masses and striking surface diameters that may be used, and a standard sample thickness is prescribed for all tests. In addition, procedures for sample preparation and treatment, as well as procedures for detecting reactions through the use of the human senses, are outlined.

3.2 Drop-weight impact tests are to be performed using the well-known Bruceton up-and-down method. ${ }^{6.7}$.

\footnotetext{
1 This method is under the furisdiction of ASTM Committee E-27 on Hazard Potential of Chemicals and is the direet responsibility of Subcommittee E27.02 on Thermal Stability,

Current edition approved Feh. 23, 1979. Published April 1979.

2 This method is a modification of and contains concepts proposed by Hercules, Inc. personnel at Allegheny Balfistics Leboratory. The method was outlined by personnel of Pittsbureh Mining and Safety Research Center, Bureau of Mines, Pinsburgh. $\mathrm{P}_{2}$. For additional trformation see footnote 3.

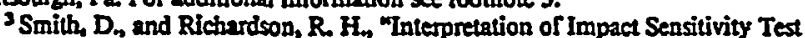
Dats," Pyradyztamics PYDYA, Vol 6, 1968, pp. 159-178.

4 Anmual Book of 1 STM Standards. Vol 15.03.

${ }^{3}$ Becker, K. R. and Watson, R. Wo, "A Critique for Drop Weight Impact Testing." Proceedings of the Conference on the Standandization of Safety and Performance Teds for Energetic Materials, Vol 1. September 1977, pp. 415-430. Publication ARICD.SP-77004, U. S. Army Armament Research and Development Command. Dover. N.J.

-Dixon, W. Jn and Messey, F. J. Jre, Introduction to Statistical Analysis, MeGraw-Hill Book Co. Inen 1957, pp. 319-327.
}

3.3 Outlined is a method for normalizing data generated on different impact apparatus.

\section{Significance and Use}

4.1 This method does not require an overall rigid standardization of the apparatus. Samples are tested either unconfined or confined in confinement cups. For confined tests, some of the important cup parameters, such as cup material, cup wall thickness, and fit between the cup and the striking pin, are standardized. Data generated from unconfined and confined tests will not, in general, exhibit the same relative scale of sensitivities, and must be identified as confined or unconfined data and compared separately.

4.2 This method applies to all testing where the intent is to establish a relative sensitivity scale for hazardous materials. It is not intended to prohibit testing process-thickness samples nor prohibit the use of other than standard tool masses and striking diameters to generate data for special purposes or for in-house comparisons. In addition, the method is not intended to restrict the generation of results at other than the $H_{30}$ point as may be desirable for hazard analysis techniques.

4.3 The normalized data will serve as a measure of the relative sensitivities of hazardous materials at the $50 \%$ probability of reaction level. The normalized $H_{50}$ values can also be used in conjunction with additional data relating to other probability of reaction levels (not a part of this method) to assess hazards associated with the manufacture, transportation, storage, and use of hazardous materials.

\section{Definitions}

$5.1 H_{50}$ value-a drop height with a $50 \%$ probability of renction, as determined experimentally by the Bruceton up-and-down method.

5.2 impact tools-the drop weight, intermediate weight, and anvil.

5.3 drop weight-that weight which is raised to a selected height and released. This weight does not impact the sample

\footnotetext{
'Statistical Research Group, Princeton University. "Statistical Analysis for a New Procedure in Sensitivity Experiments" AMP Report No. 101.IR. SRG-P, No. 40, Submitted to Applied Mathematies Panel, National Defense Research Commitree, July 1944, $58 \mathrm{pp}$.
} 
directly; rather it strikes another stationary weight that is in contact with the sample.

5.4 intermediate weight-the stationary weight in contact with the sample.

5.5 anvil-the smooth, hardened surface upon which the test sample or cup containing the sample rests.

5.6 unconfined test-a test in which the test sample is placed directly upon the anvil with no lateral confinement.

5.7 confined test - a test in which the test sample is contained within a confinement cup (sample container), and the confinement cup is then placed upon the anvil.

5.8 confinement cup-the metal sample container used in confined tests.

5.9 guide bushing-the steel bushing that surrounds, aligns, and holds the stationary intermediate weight in place.

5.10 guide system-the rails, wires, and shat that guide the drop weight during its fall.

5.11 striking surface-the hardened, smooth, circular bottom surface of the intermediate tool that is in contact with the test sample.

5.12 impact apparatus or machine-the total apparatus including the foundation parts, guide rails, electromagnet lift, winch, and tools.

\section{Apparatus}

6.1 A complete impact apparatus is the specialized apparatus necessary for this method.

6.2 The masses of the drop weight $\left(m_{1}\right)$ and intermediate weight $\left(m_{2}\right)$ should, preferably, be equal. However, the intermediate weight mass may be less than that of the drop wcight mass so long as the mass ratio $m_{2} / m_{1}$ is 0.6 or greater. This ensures that the force-time stimulus a test sample is subjected to will be nonoscillatory in nature, and ensures that the transfer of energy from the drop weight to the intermediate weight does not vary significantly.

6.3 The mass of the drop weight should be between 1.0 to $3.5 \mathrm{~kg}$.

6.4 The hardness of all tooling surfaces involved in the impact (drop weight, intermediate-weight, and anvil) should have a Rockwell $C$ Hardness of 55 to 59 HRC.

6.5 The diameter of the striking surface of the intermediate weight shall be 9.52 to $19.05 \mathrm{~mm}$ ( $3 / 6$ to $3 / 4$ in.). These limits were determined simply on the basis that data have been successfully normalized for tool diameters in this range.

6.6 The finish on the striking surface of the intermediate weight and of the anvil, though not highly critical in tests with solid explosives, should be a No. 8 grind $(8 \mu \mathrm{in}$ ) or finer. If substantially different surface finishes are used, the data obtained should be accompanied by a footnote specifying the finish used.

6.7 In confined tests, the confinement cup shall be fabricated from Type 302 stainless steel. The cup base thickness shall range from 0.13 to $0.15 \mathrm{~mm}(0.005$ to $0.006 \mathrm{in}$.). The outer periphery of the striking pin shall be in contact with a small portion of the arc joining the side and bottom of the cup. Although this permits greater energy losses in working the metal inside the cup than if the whole striking surface engaged only the flat portion of the metal in the base of the cup, it does ensure better confinement with less flow of test material up the sides of the striking pin and cup. A typical confinement cup is shown in Fig. 4. This, together with the striking pin dimensions shown in Fig. 3, provide some insight on a suitable mating between the striking pin and cup.

6.8 Experience has shown that an appreciable difference in the behavior of the apparatus can result from the manner in which it is mounted. Thus, the machine should be mounted on, and firmly attached to, a solid concrete foundation, preferably anchored to the foundation of a building (see Method D 2540).

6.9 Figure 1 illustrates a typical impact apparatus, and Figs. 2 through 4 are detailed drawings of a drop weight, an intermediate weight, and a confinement cup. Helpful notes on construction of the tools are found in the Appendix. These tools and apparatus are in use at the U. S. Bureau of Mines, Bruceton, Pa; but are not necessarily the only acceptable designs. All designs, however, should incorporate a device that captures the drop weight after it rebounds to prevent further interactions with the intermediate weight.

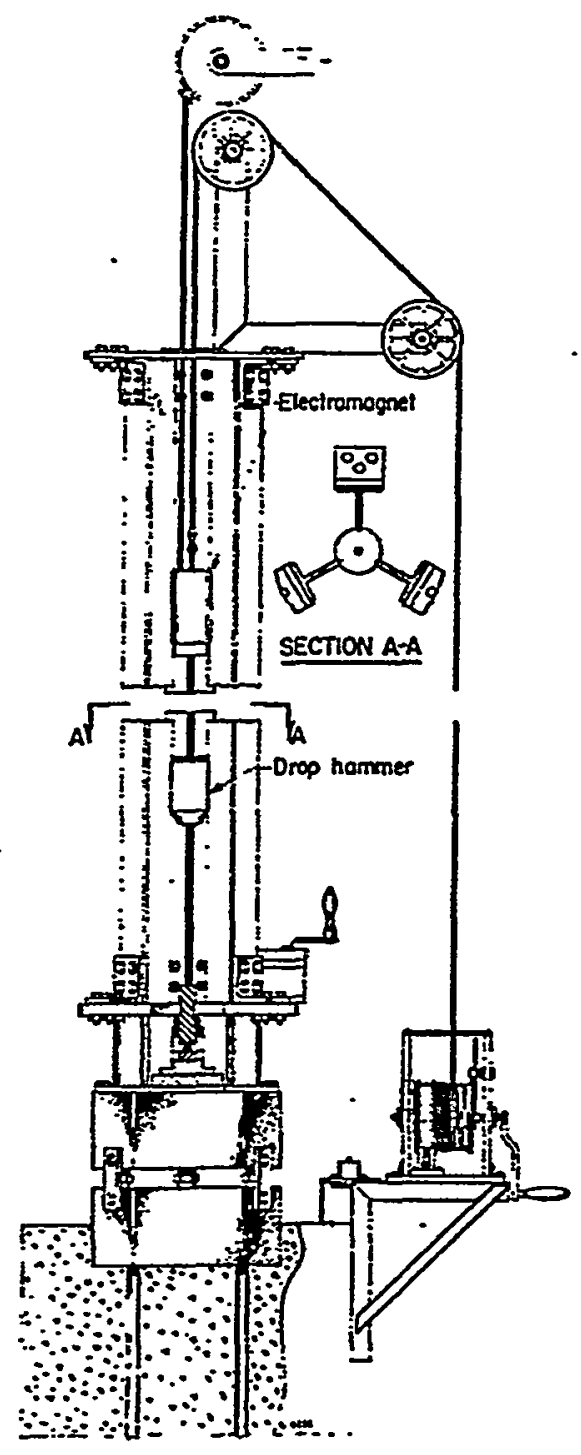

F1G. 1 Bureau of Mines Impact Apparatus 


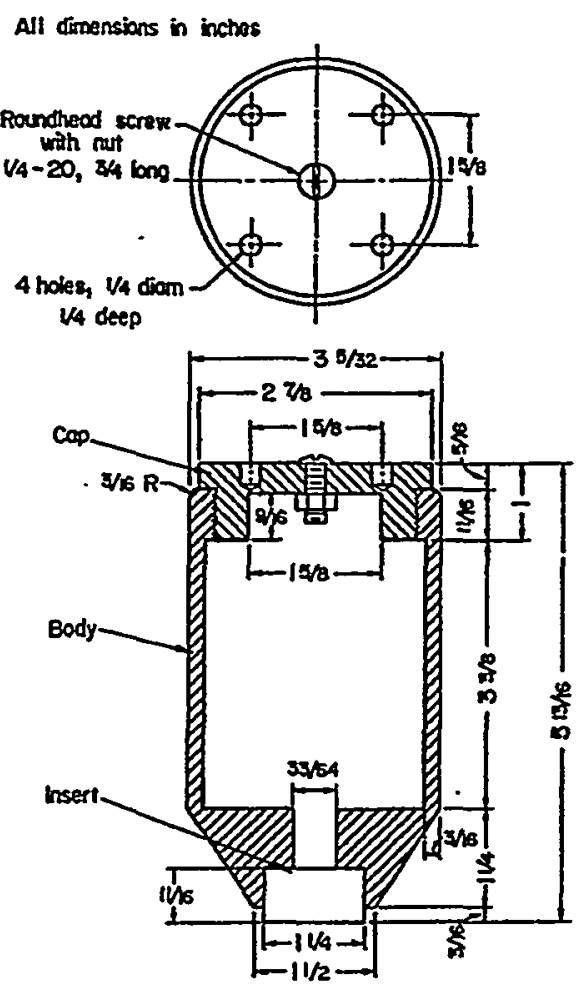

FIG. 2 Drop Weight Assembly

\section{Test Sample}

7.1 Sample thickness must be the same for all tests. This is achieved by using a constant volume per unit area sample spread uniformly over that area. The standard is $\mathbf{3 1 . 5}$ $\mathrm{mm}^{3} / \mathrm{cm}^{2}$. This provides a distributed thickness of 0.315 $\mathrm{mm}$ (12.4 mils) and ensures the same energy input per unit mass of a given test material no matter what the diameter of the striking surface area is. Thus, for a sample diameter of $12.7 \mathrm{~mm}(0.50 \mathrm{in}), 40 \mathrm{~mm}^{3}$ of sample volume would be used. Proportionately larger or smaller sample volumes, varying in direct proportion to the sample, may be used so long as the sample volume per unit area is $31.5 \mathrm{~mm}^{3} / \mathrm{cm}^{2}$. Errors in sample volume may be $\pm 10 \%$, and sample measuring spoons having the appropriate volume can be machined .or drilled for this purpose. In cases where it is desirable to test process thickness samples that differ from the standard, simply indicate the thickness used, especially if the $H_{50}$ values appear in the same tables together with $H_{50}$ values obtained using standard thickness samples.

7.1.1 In some cases, the sample consistency may prohibit the sample from being measured in a measuring spoon. In these instances, the proper sample size can be determined by its mass; $M=\rho V$, where $V$ is the proper volume for a given sample area, and $\rho$ is the loose-packing density of the sample. The density may have to be determined if it has not been specified.

7.2 Specifications of sample diameters to be used in conjunction with different diameter tools are as follows: $(a)$ in confined tests, specifically, a test where the sample is confined in a cylindrical cap, the sample diameter will be the

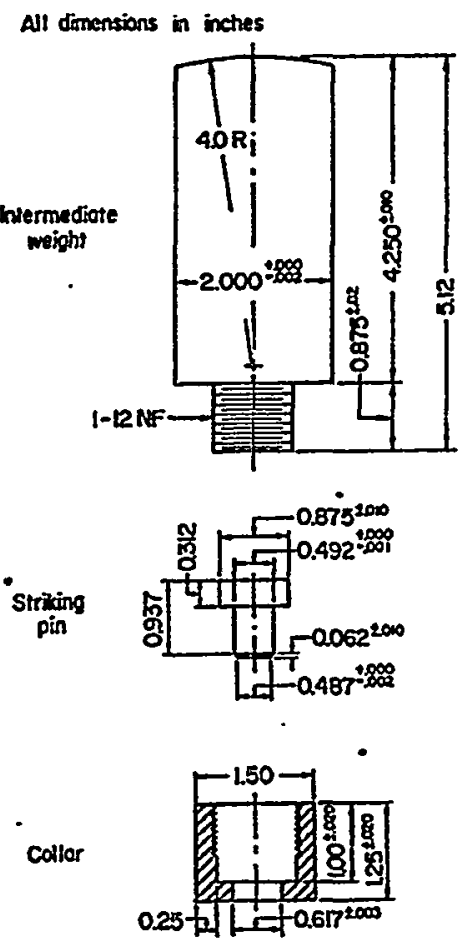

FIG. 3 Intermediate Wolght Assembly

same as the inside diameter of the cup. Hence, calculate a sample volume or mass based upon the inside diameter of the confinement cup, and $(b)$ for unconfined tests, specifically, a test where the sample is spread directly upon the anvil, use about a $0.33-\mathrm{mm}$ (13-mii) thick template made from plastic, metal, or tape having a circular hole cut in it. Place the template on the anvil, pile the sample in the hole, and scrape level with a spatula or straight edge. The hole diameter should, in all cases, be somewhat larger than the 1001 contact surface diameter. Leave the template in place during the impact trial. The larger size will make it easy to

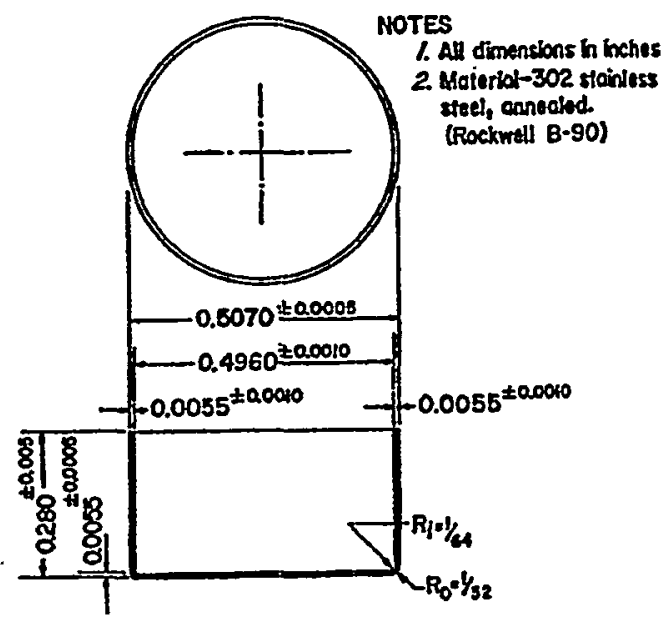

FG. 4 Confinement Cup Used as a Sample Container In Confined Tests 
miss striking the periphery of the template hole during impact. The template also serves as an excellent means for keeping the sample inbounds. The recommended template hole for a $12.7-\mathrm{mm}$ (1/2-in.) diameter tool is $15.9 \mathrm{~mm}$ ( $5 / 8 \mathrm{in}$.), but it may be $19.1 \mathrm{~mm}$ (3/4 in.) or larger, as long as a proportionally larger sample is used. Here, it is important to remember that the sample volume or mass used to obtain constant-thickness samples is based upon the template diameter, not the tool diameter.

7.2.1 In no case should the sample diameter be less than that of the tool. The normalization method cannot be applied if this is the case. Furthermore, the normalization method cannot be applied to mixed data from confined and unconfined tests. It is generally applicable in the unconfined case. Information is limited on applicability to the confined case. However, it is believed that data from confined trials could be normalized provided the confinement parameters are reasonably alike. The important cup parameters that were standardized were given in 6.7.

\section{Preparation of Apparatus}

8.1 Inspection checks of the apparatus are an important part of the test procedure. This includes the physical condition of certain parts, alignment, and cleanliness.

8.1.1 Physical Condition of Equipment-Inspect the guide rails, or wires, or shafts periodically for evidence of nicks, frays, dirt, or other physical impairments, and eliminate any defects that might impede the drop weight in its fall. Inspect the drop weight, intermediate weight, and anvil, making especially sure that all metal surfaces that are involved in the collision process are free from defects. Make sure that the intermediate weight slides through and rotates freely in the guide bushing without significant side play. Recondition or replace the bottom surface (striking surface) of the intermediate weight or top surface of the anvil if they show any cvidence of wear. Use a new, clean confinement cup each trial in confined tests if confinement cups (sample containers) are used.

8.1.2 Alignment-Align the guide system, allowing the drop weight to fall along a path perpendicular to the plane of the earth within \pm 0.25 deg. Misalignments of this magnitude can easily be detected using a plumb line, since a 0.25 -deg misalignment amounts to a $13-\mathrm{mm}$ displacement over a 3000-mm length.

8.1.2.1 Align the bottom face (striking surface) of the intermediate weight and the top surface of the anvil. These surfaces must be both plane and parallel. A convenient way to check this is with Prussian blue dye. Place a small amount of the dye on a piece of paper and insert the paper between the intermediate tool striking surface and anvil. By hand lower the intermediate tool onto the area of the paper containing the dye. Lift the intermediate tool and insert a clean piece of paper. Lower and raise the tool a number of times on different areas of the clean paper, making many different imprints. Be careful not to make a judgment solely on the basis of the first or second imprint, since an excess of dye might smear and cover up defects. If the two surfaces are not parallel, a portion of one side of the circle will be missing, A convex tool striking surface will produce a circle having a diameter less than that of the tool striking surface, whereas a concave tool will produce a normal diameter circle with the bare spot centrally located. If any of these defects or others are noted, take proper steps to eliminate them.

8.1.3 Cleanliness-Keep all surfaces of the weights, guides, and interior of the guide bushing reasonably clean at all times. Clean especially the intermediate tool striking surface and top of the anvil for each trial. All traces of explosive or residue from reactions must be removed with a tissue wet with acetone, and then wiped with clean, dry tissue. Clean the bottom surface of the drop weight and top surface of the intermediate weight several times during an up-and-down tèst.

\section{Procedures}

9.1 Avoid testing hygroscopic materials under high humidity conditions, if climate control is not available. Sample conditioning and certain test procedures can be implemented to minimize humidity effects.

9.2 For materials that have been stored under unknown or high humidity conditions, vacuum dry the samples for $\mathbf{2 h}$ at $90^{\circ} \mathrm{C}$. For test samples thermally sensitive to $90^{\circ} \mathrm{C}$ vacuum dry for $8 \mathrm{~h}$ at $50^{\circ} \mathrm{C}$.

9.3 After drying, place the material in a tightly sealed container and store in a desiccator. The materials should be tested within several days after drying.

9.4 Transfer a sample amount sufficiently large for a complete $H_{50}$ run to a smaller, dry container and work out of the small container for the up-and-down test, closing up the small container between trials.

9.5 Some materials should not be dried, specifically, those that would lose volatile constituents. These, of necessity, should be sealed in air-tight containers until ready for use. It is advisable to transfer a suitable amount to a smaller container for the $H_{50}$ test.

9.6 The test results may vary depending on particle size distribution. Some crystalline materials contain several crystal forms. One form may be, for example, larger in dimensions and more sensitive to impact. Screening may concentrate or remove the more sensitive crystal forms. In general, comparisons are valid only if the particle size distributions are the same. No rigid guidelines for screening all samples in a like manner are given here because some samples cannot be screened, and it may be desirable in many cases to test samples in the "as received" particle size distribution.

9.6.1 In some cases, the size of the sample particles may be inordinately large and the proper test sample thickness cannot be maintained without some reduction (crushing) of particle size. Therefore, with the exception of cases where it is desirable to test process size particles, crush the particles to an extent so that the sample can be distributed uniformly over the template hole area or cup base area with little or no metal visible between sample particles. Cantion-Where particle size reduction by grinding is necessary, the user of the method should determine if the material is dangerous, and use remote grinding methods if in doubt. It should also be pointed out that the proper volume of sample to be used for a test should be measured out from the crushed sample.

9.7 For unconfined tests, center a template upon the anvil beneath the intermediate tool striking surface, fasten with tape, and with a small spatula distribute the proper volume of sample (see 7.1 and 7.2) uniformly over the entire 


\section{O. Dworjanyn

template hole area with as few ridges and valleys as possible. Do not press down or tamp the sample unduly. Lower the intermediate tool gently upon the sample without a twisting motion.

9.8 Use the same procedure for the confined test, except distribute the proper size sample in the bottom of the cup, making sure that the cup and sample remain level while positioning the cup on the anvil. Do not twist the tool after insertion in the cup.

9.9 Proceed with the Bruceton up-and-down method as described in Dixon and Massey ${ }^{6}$ in which the next trial after a "go" is performed at one test level lower; while after a "no-go," the next test is performed at one higher test level. The minimum number of tests recommended is 21 . Caution-The operator performing the test should wear safety glasses with side shields in all preparations prior to the release of the drop weight, and should be positioned behind a shield or in a remote location when the drop weight is released.

9.10 Suggested test heights are given in Table 1. They are based upon equal log intervals and are quite suitable for the errors normally encountered in impact testing. If these intervals are not suitable, similar tables having more closely or more widely spaced intervals may be constructed. Equally spaced "real height" intervals will also produce satisfactory $H_{s 0}$ values and may be used. A rule of thumb is to choose an interval that is about 20 to $25 \%$ as large as the "guessed" $H_{50}$ value.

\section{Reaction Detection}

10.1 This is one of the more troublesome areas in sensitivity testing that can significantly alter test results. Guidelines that establish a cut-off point between a reaction and a nonreaction are mandatory, no matter how arbitrary they may appear to be. A reaction (go) is defined as an impact that produces one or more of the following phenomena: (a) audible report, (b) flame or visible light, (c) definite evidence of smoke (not to be confused with a dust cloud of dispersed sample), and (d) definite evidence of discoloration of the sample due to decomposition. The main

TABLE 1 Suggested Scale of Normallzed Helghts

\begin{tabular}{ccc}
\hline Log herement & $\begin{array}{c}\text { Corresponding } \\
\text { Hoight (mm) }\end{array}$ & $\begin{array}{c}\text { Test Height } \\
\text { (nearest } 5 \mathrm{~mm} \text { ) }\end{array}$ \\
\hline 1.705. & 60.7 & 60 \\
1.605 & 63.8 & 65 \\
1.005 & 80.4 & 80 \\
2.005 & 101.0 & 100 \\
2.105 & 127.0 & 125 \\
2.205 & 160.0 & 160 \\
2.005 & 202.0 & 200 \\
2.105 & 254.0 & 255 \\
2.505 & 320.0 & 320 \\
2.605 & 403.0 & 105 \\
2.705 & 607.0 & 505 \\
2.805 & 638.0 & 640 \\
2.805 & 804.0 & 805 \\
3.005 & 1012.0 & 1010 \\
3.05 & 1274.0 & 1275 \\
3.205 & 1609.0 & 1605 \\
3.305 & 2018.0 & 2020 \\
3.405 & 2541.0 & 2540 \\
3.50 .5 & 3199.0 & 3200 \\
\hline
\end{tabular}

A Test heights have been rounded off to nearest $5 \mathrm{~mm}$ because the apparatus in quastion is adjustable in 5 -mm increments. concern is with reactions that have no distinguishable audible report, no flame, and little sample consumption. The cut.off point in these cases is based primarily upon the appearance of the sample after the test. The impact in most cases will compress the sample into a thin wafer. Portions of the wafer may adhere to the striking tool surface, the anvil, or both. Inspect the tool and anvil surfaces and look for voids (missing wafer parts). Look for discoloration due to decomposition in areas where voids occur. If there is discoloration from decomposition, specify the trial as a reaction. If there are small voids and no discoloration, specify the trial a nonreaction. If doubt exists whether or not discoloration is present, specify the trial a nonreaction. If the only evidence is a slight odor or a small amount of smoke, which may be a dust cloud from dispersed sample, consider the trial a nonreaction.

\section{Calculation}

11.1 Table 2 and Fig. 5 show the individual trial results in the order in which they were performed, as well as a sunmary of data and calculations needed for a typical up-and-down test. The various test heights in this case were based on equal log intervals (see Table 1). Estimates of the mean $(m)$ and standard deviation $(S)$ are computed on a $l o g$ basis. The antilog of $\boldsymbol{m}$ is the $H_{50}$ value in real-height terms. If equally-spaced test intervals had been used, the values of $m$ and $S$ could have been computed directly in real-height terns.

Note 1-Consult Dixon and Massey or any other suitable source for a more complete treatment of the up-and-down method if needed.

11.2 Important data that should be recorded together with the up-and-down test results are as follows:

11.2.1 Drop and intermediate weight masses and tool striking surface diameter,

11.2.2 Confined or unconfined test

11.2.3 Volume (or mass and density) of sample used in a test;

11.2.4 Diameter or area of sample in unconfined tests, or the interior diameter of the sample cup in confined tests,

11.2.5 Sample treatment (drying or screening), if any, and

11.2.6 Any other departures from standard procedure outlined in this method.

11.3 The information in 11.2.1 is needed to normalize the $H_{\text {S1) }}$ value for comparison with another normalized $H_{50}$

TABLE 2 Calculations for Up-and-Down Test

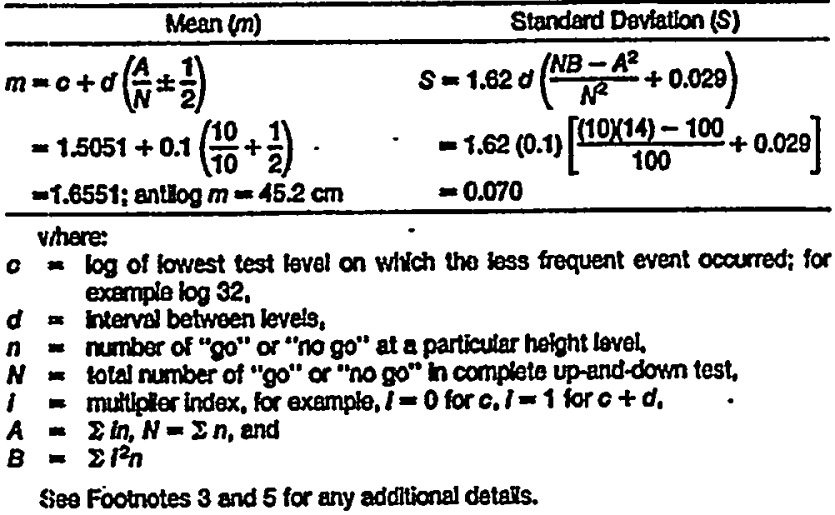




\section{E 680}

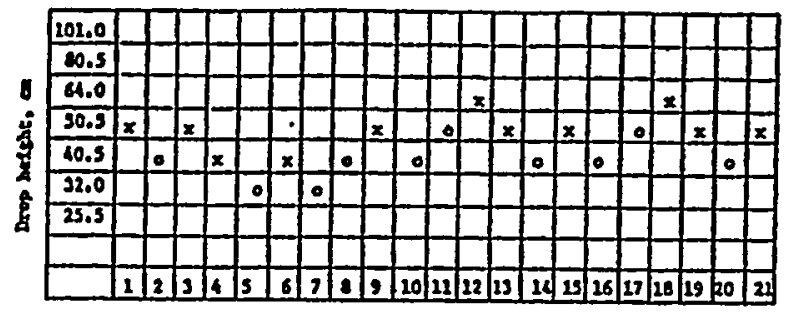

Trial

(a) Results for Indivitual trials.

\begin{tabular}{|c|c|c|c|c|c|}
\hline & $\left(0^{x}\right)$ & $\left(100^{6} 00\right.$ & 1 & $\ln$ & $1^{2} \mathrm{a}$ \\
\hline 64.0 & 2 & 0 & 3 & 0 & 0 \\
\hline 30.5 & 7 & 2 & 2 & 4 & 8 \\
\hline 40.5 & 2 & 6 & 1 & 6 & 6 \\
\hline 32.0 & 0 & 2 & 0 & 0 & 0 \\
\hline & & & & & \\
\hline$I$ & 11 & 10 & & 10 & 16 \\
\hline & & & & 1 & 2 \\
\hline
\end{tabular}

(b) Organkzation of pertinent quantities for calculations. For identification of quanilltes see Tablo 2.

FIQ. 6 Example of Data Organization for Up-and-Down Test

value. The information in 11.2.2 through 11.2.6 contains a number of important test parameters that should be the same (or correct) in order that valid comparisons can be made.

11.4 Statistical testing for the equivalence of means is outside the scope of this method and is discussed in the literature previously cited. A good rule of thumb for making decisions is to subtract the two normalized $H_{50}$ values. Then simply compare this difference with the larger of the two normalized standard deviations (the standard deviations are normalized by mass per unit area $(M / A)$ in the same manner as the $H_{50}$ values are (see 11.5). If the difference is less than the normalized standard deviation, then the $H_{50}$ values would quite probably also not be found to be different at the $95 \%$ level of significance in the statistical test procedure described in the reference cited. The statistical test or rule of thumb method must be performed in log terms if equal log intervals determined the height test levels, or be performed with real-height quantities $\left(H_{50}\right.$ and $\left.S\right)$ if equal interval heights were used.

11.5 The procedure for normalizing data obtained for a given material on two different drop weight impact testers, utilizing different mass and striking diameter tools, may be accomplished in two ways: (a) apply normalizing factors to one $H_{s 0}$ value to put it on a comparable basis with the other, or (b) apply normalizing factors, $M / A$, to both $H_{30}$ values, producing comparable normalized $H_{s 0}$ values that are unlike either initial $H_{50}$ value.

11.5.1 The methods are described as follows: Apparatus A:

drop weight mass $=2.0 \mathrm{~kg}$,

intermediate tool striking diameter $=12.7 \mathrm{~mm}(1 / 2$ in. $)$, intermediate tool striking area $=1.27 \mathrm{~cm}^{2}$, and

$H_{s 0}=500 \mathrm{~mm}$ (for explosive $\mathrm{XX}$ ).

Apparatus B:

drop weight mass $=3.0 \mathrm{~kg}$,

intermediate tool striking diameter $=9.52 \mathrm{~mm}(3 / 8 \mathrm{in})$,

intermediate tool striking area $=0.712 \mathrm{~cm}^{2}$, and

$H_{50}=187 \mathrm{~mm}$ (for explosive XX).

11.5.2 Method 1-The effects from the larger drop weight mass and smaller intermediate tool striking diameter associated with apparatus B are to produce lower $H_{50}$ values relative to that obtained from apparatus $A$. Two normalizing factors, both greater than unity, representing the mass and diameter (or area) effects must be applied to the $H_{50}$ value obtained with apparatus B to put it on a comparable basis with that from apparatus $A$.

Mass factor: $3 \mathrm{~kg} / 2 \mathrm{~kg}=1.50$

Diameter factor: $(12.7 \mathrm{~mm} / 9.52 \mathrm{~mm})^{2}=1.78$

or

Area factor: $\left(1.27 \mathrm{~cm}^{2} / 0.712 \mathrm{~cm}^{2}\right)=1.78$

Total factor: $(1.5)(1.79)=2.68$

Normalizing $H_{50}^{B} \rightarrow H_{50}^{A}:(2.68)\left(H_{50}^{B}\right)=(2.68)(187 \mathrm{~mm})=500 \mathrm{~mm}$

11.5.3 Method 2-Both $H_{50}$ values are multiplied by their respective $M / A$ values,

$M_{t} / A_{t} H_{s 0}^{l}=$ constant.

$M_{A} / A_{A} H_{50}^{A}=(2.0 / 1.27 \times 500 \mathrm{~mm})=790 \mathrm{~mm}$

$M_{B} / A_{B} H_{50}^{B}=(3.0 / 0.712)(187 \mathrm{~mm})=790 \mathrm{~mm}$

11.5.4 Both methods accomplish the desired objective, that is, normalizing out the effects from differences in tool mass and striking area. The standard deviations $S$ may be normalized in a similar manner if the up-and-down test was performed initially using equal real (not log) height intervals and a statistical test for equivalence of means may be performed in real-height terms. However, it should be mentioned that a peculiar characteristic of the Bruceton up-and-down method is that if equal-spaced log intervals are used, $S$ cannot be transformed on a real-height basis (by taking the antilog), as may be done with the mean. If a statistical test for equivalence of means is desired, the whole procedure for normalizing data and the statistical test must be performed in log terms.

\section{Precision and Accuracy}

12.1 The precision of the test is limited by the drop height interval $(d)$ used. The standard deviation estimate (S) must be comparable in magnitude to the interval.

12.2 The acceptance or rejection of test results are governed by the following rule; accept the test if $1 / 2 d \leq S \leq 2 d$. Otherwise, repeat the test using an appropriately larger or smaller interval.

12.3 Based upon $H_{50}$ tests performed at one establishment, the average ratio of the standard deviations $(S)$ to the mean values obtained $(m)$ from many explosive tests was approximately $0.20(20 \%)$. This average ratio was obtained from data having real height (not log) values, and provides additional insight on the precision that may be expected from the test. It is on this basis that the original choice of an interval is recommended to be about 20 to $25 \%$ of the "guessed" mean. 


\section{APPENDIX \\ - (Nonmandatory Information)}

\section{- X1. CONSTRUCTION NOTES ON DROP WEIGHT TOOLS}

\section{X1.1 Intermediate Weight Assembly:}

X1.1.1 Material for intermediate weight and striking pins must be of a type steel that can be hardened to 55 to 59 HRC on the Rockwell C scale. The collar may be cold, rolled steel.

X1.1.2 With the exception of the bottom surface of striking pins, all sharp edges and corners on hardened parts should be broken as much as is consistent for the proper mating of parts. The purpose of this is to eliminate stress points and possible crack formation.

X1.1.3 It would be convenient if collar were made of "hex" stock. If made of round stock, grind flat areas (180 deg apart) on exterior surface so that the collar can be tightened with a wrench.

X1.1.4 Total mass of the three parts must be $2.00 \pm 0.04$ $\mathrm{kg}$. To meet this condition, the length of the intermediate weight is altered as necessary. Check the mass prior to hardening.

X1.1.5 After hardening, grind top and bottom surfaces of intermediate weight and striking pins to a No. 8-grind finish or finer.
X1.1.6 The details of the base of the striking pin, that is, the 0.492-in. shaft diameter and 0.487-in. relieved diameter are compatible with a good fit into a standard stainless steel cup used by the Bureau of Mines as a sample cup in confined testi.

\section{X1.2 Drop Weight:}

X1.2.1 Total mass of drop weight (cap, body, and insert) must be $2.00 \pm 0.04 \mathrm{~kg}$. Dimensions as given will result in a slight overweight. Trim inside surfaces of body to reduce mass.

X.1.2.2 The insert (the element that strikes the intermediate weight in a drop test) should be made of a type of steel that can be hardened to 55 to 59 HRC on the Rockwell C scale. The fit of the insert into the main body should be a metal-to-metal press fit. The main body may be heated and insert chilled to facilitate pressing.

X1.2.3 The purpose of a machine screw-in cap is to facilitate seating of the drop weight in an electromagnetic pick-up head used by the Bureau of Mines to raise the drop weight to a desired drop height. This detail may be altered to suit individual needs.

\footnotetext{
The Amorican Society for Testing and Materials takes no position respocting the valldity of any patent rlohts asserted in connection with any kem mentioned in thls standerd. Users of this standard are exprnssly advised that delermination of the valifily of any such patent rights, and the risk of Intrhgement of such rights, aro entirely their own responsibility.
}

This stendiard is subfect to revision at any time by the responsible tochuical committee and must be reviewed evary tho yoars and II not revised, either reapproved or withdrawn. Your comments are invited ather for revision of this standard or for additional standards and should be addressed to ASTM Headquarters. Your comments with receive carafut conslderation at a meelting of the responsiblo techical committee, which you may attend. II you feel that your comments have not recelved a fair hearting you should make your views known to the ASTM Committee on Stendards, 1916 Race St, Phtradelphia, PA 19103. 


\section{Appendix G \\ Sludge Vendor Testing Scope of Work, Rev. 1}

\section{BACKGROUND}

High Level Waste (HLW) radioactive sludge at Savannah River Site (SRS) is being vitrified to glass for permanent safe disposal. The caustic sludge, stored in $1 \mathrm{MM}$ gal waste tanks, is normally slurried and washed in the tanks by water addition, agitation, and decantation, and the residual insoluble residue is pumped to the Defense Waste Processing Facility (DWPF) for vitrification.

The sludge in some of the storage tanks has dried and solidified, creating the possibility that explosive compounds may have formed, presenting a risk in sampling and waste recovery. Of particular concern are mercury compounds, such as mercury fulminate, $\mathrm{Hg}$ (ONC) ${ }_{2}$, mercury oxalate, $\mathrm{HgC}_{2} \mathrm{O}_{2}$, and Millon's base, $\mathrm{Hg}_{2} \mathrm{NOH} .2 \mathrm{H}_{2} \mathrm{O}$, since the sludge can contain up to $6 \mathrm{wt} \%$ mercury. Silver nitride, $\mathrm{Ag}_{3} \mathrm{~N}$, is also a possibility, but the concentration would be very low, below $0.01 \mathrm{wt} \%$.

The is no direct evidence that these or other explosive compounds are present in the sludge. In fact, mercury fulminate is unstable under wet caustic conditions, although it could exist in a dry state.

\section{OBJECTIVES}

Assess the safety of dry HLW sludge containing 5 to $10 \mathrm{wt} \%$ mercury fulminate.

\section{APPROACH}

1. Demonstrate at vendor facilities the safety of mercury fulminate/sludge compositions using non-radioactive simulated sludge containing vendor prepared synthetic mercury fulminate at up to $10 \mathrm{wt} \%$.

2. Confirm the safety assessment at the Savannah River Technology Center (SRTC), using simulated sludge and SRTC prepared mercury fulminate.

3. Test actual HLW radioactive sludge at SRTC inside shielded hot cells.

\section{VENDOR SCOPE OF WORK}

1. Prepare caustic and neutral sludge for testing.

2. Synthesize mercury fulminate for testing.

3. Prepare blended sludge/fulminate samples for testing, including:

- Dry mercury fulminate on dry caustic sludge.

- Wet mercury fulminate blended with wet neutral sludge, dried for testing.

- Wet mercury fulminate blended with wet neutral sludge containing organics. 
4. Conduct testing on:

- Pure mercury fulminate.

- Dry mercury fulminate mixed in with dry caustic sludge.

- Wet-blended neutral sludge/mercury fulminate.

5. Prepare written assessment of explosive hazard for simulated sludge/mercury fulminate compositions.

\section{VENDOR TESTS TO BE PERFORMED}

1. Differential Scanning Calorimetry (DSC), $\sim 10 \mathrm{mg}$ sample

2. Falling Hammer Test (Impact), $30 \mathrm{mg}$ sample

3. Thermal Stability Test (Thermal), 20 to $50 \mathrm{mg}$ sample.

\section{TOTAL VENDOR TESTS}

\begin{tabular}{|l|l|l|}
\hline TEST & $\#$ & Mix Composition \\
\hline & & \\
\hline DSC & 1 & Caustic sludge \\
\hline & 1 & Neutral sludge \\
\hline & 2 & $10 \mathrm{wt} \% \mathrm{Hg}(\mathrm{ONC})_{2}$ in caustic sludge \\
\hline & 2 & $10 \mathrm{wt} \% \mathrm{Hg}(\mathrm{ONC})_{2}$ in neutral sludge \\
\hline & 2 & Pure mercury fulminate, $\mathrm{Hg}(\mathrm{ONC})_{2}$ \\
\hline & & \\
\hline Impact & 1 Set & $5 \mathrm{wt} \% \mathrm{Hg}(\mathrm{ONC})_{2}$ in caustic sludge \\
\hline & 1 Set & $10 \mathrm{wt} \% \mathrm{Hg}(\mathrm{ONC})_{2}$ in caustic sludge \\
\hline & 1 Set & $5 \mathrm{wt} \% \mathrm{Hg}(\mathrm{ONC})_{2}$ in neutral sludge \\
\hline & 1 Set & $10 \mathrm{wt} \% \mathrm{Hg}(\mathrm{ONC})_{2}$ in neutral sludge \\
\hline & 1 Set & Pure mercury fulminate, $\mathrm{Hg}(\mathrm{ONC})_{2}$ \\
\hline & & \\
\hline Thermal & 1 & $5 \mathrm{wt} \% \mathrm{Hg}(\mathrm{ONC})_{2}$ in neutral sludge \\
\hline & 1 & $10 \mathrm{wt} \% \mathrm{Hg}(\mathrm{ONC})_{2}$ in neutral sludge \\
\hline & 1 & $10 \mathrm{wt} \% \mathrm{Hg}(\mathrm{ONC})_{2}$ in caustic sludge \\
\hline & & \\
\hline
\end{tabular}

\section{QUALITY ASSURANCE}

1. Vendor will document all tests and include the documentation in final report.

2. SRTC representative shall witness key tests to assure equivalence with SRTC testing of the radioactive waste. 


\title{
Chilworth Technology, Inc

\author{
Appendix H \\ Vendor Final Report
}

Princeton Corporate Plaza

11 Deer Park Drive

Monmouth Junction,

New Jersey 08852-1923

Telephone: (732)274-0900

Facsimile: (732)274-1371

email: safety@chilworth.com

http:/www.chilworth.com

\author{
MERCURY FULMINATE \\ (IN PURE FORM AND IN DRY SLUDGE) \\ IMPACT SENSITIVITY AND CALORIMETRY \\ SCREENING
}

TO : Westinghouse Savannah River Company

SRS, Building 735 - 11A

Aiken, SC 29808

F.A.O. : Mr. Lee Dworjanyn

Prepared By

Benjamin J. Carey

Laboratory Technician
Reviewed By ...p.r...................

Richard C. Wedlich

Sr. Process Safety Specialist

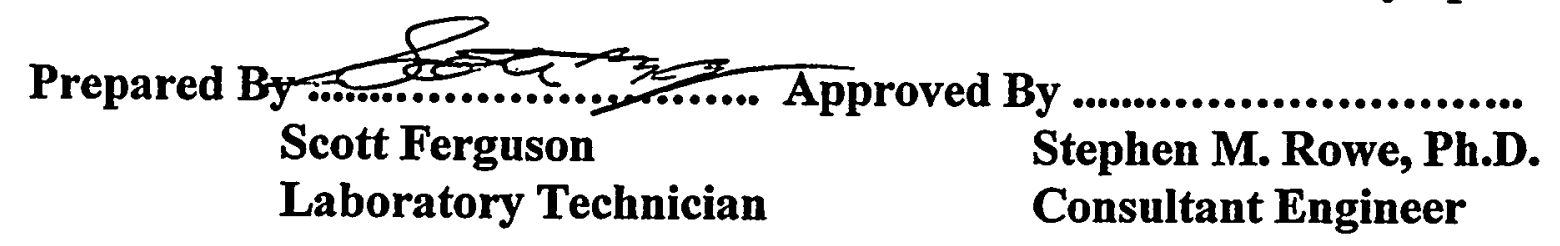

FOR AND ON BEHALF OF CHILWORTH TECHNOLOGY, INC.

Report No : $\quad R / 1905 / 0399 / B C$

Date : May 20, 1999

Our Ref : WE1905RP 


\section{CONTENTS}

PAGE

1. PROGRAM OBJECTIVE 1

2. INTRODUCTION 1

3. SUMMARY 3

3. SCOPE OF THE ASSESSMENT 6

4. TEST OBJECTIVES

5. APPROACH 8

6. EXPERIMENTAL 10

A. Sample Information 10

B. Procedure to prepare sludges 10

C. Test Matrix 11

D. Differential Scanning Calorimetry (DSC) 12

E. Dropweight Test 13

F. Carius Tube Test $\quad 15$

$\begin{array}{ll}\text { 7. TEST RESULTS } & 17\end{array}$

8. DISCUSSION 28

9. SUGGESTIONS FOR FURTHER TESTING 31

10. REFERENCE LIST 32

\section{APPENDIX:}

Appendix 1 Test Standards

Appendix 2 Customer Procedure for Fulminate Preparation Test

Appendix 3 Calibrations

Appendix 4 DSC Thermograms

Appendix 5 Carius Tube Thermograms

Appendix 6 Apparatus (Fallhammer and Carius)

Appendix 7 Raw Data 


\section{PROGRAM OBJECTIVE}

The purpose of this experimental program is to provide fundamental data that will aid Westinghouse Savannah River Company in their assessment of the potential for mixtures of mercury fulminate with dry inorganic sludge to undergo detonation upon exposure to impact and heat. Since energy can be delivered to a material by mechanisms other than just shock and uniform heating, the determination of the impact sensitivity and thermal stability forms only part of a comprehensive assessment of the "detonability" of the material.

\section{INTRODUCTION}

The Westinghouse Savannah River Company is concerned that a number of their large storage tanks containing an inorganic sludge may also contain a small fraction of an explosive material. The material is postulated to be mercury fulminate.

As a pure material, mercury fulminate is extremely dangerous owing to its propensity to detonate upon impact. It is highly sensitive to frictional heating, sparks and flames, which can cause it to detonate. The heat of formation of the compound is reported to be +941 $\mathrm{kJ} / \mathrm{kg}$ (p.221 of Rudolf Meyer's textbook, "Explosives"), hence the decomposition reaction - is expected to be highly exothermic.

Testing was performed at Chilworth Technology, Inc. to determine the impact sensitivity of "mock" sludge samples. Pure mercury fulminate served as an "internal standard" for the method. The "mock" sludges were prepared by spiking (either $5 \%$ or $10 \%$ by weight) mercury fulminate into either neutral sludge or caustic sludge. The sludges themselves were provided by Westinghouse Savannah River Company. Owing to the difficulty in shipping mercury fulminate, the explosive was prepared at Chilworth Technology, Inc. (in small quantities as needed) following a procedure provided by the customer. 
The impact sensitivity was determined following the ASTM method. Thermal stability testing involved Differential Scanning Calorimetry (on milligram- sized samples) and the ICI 10gram Closed Carius Tube test (on gram -sized samples). 


\section{SUMMARY}

The impact sensitivity of mercury fulminate solid was clearly demonstrated. Seven out of seven samples tested from a drop height of $125 \mathrm{~cm}$ gave a positive result. The criteria for a positive test result was based on observation of the impact residue. "Positive" was interpreted as fine gray ash-like residue. "Negative".was interpreted as white powder containing some gray flakes. Six out of six samples tested from a drop height of $80 \mathrm{~cm}$ gave a negative result.

Impact tests of sludge (neutral or caustic) spiked with mercury fulminate ( $5 \%$ or $10 \%$ by weight) produced a "negative" result on all samples tested at the maximum height of 270 $\mathrm{cm}$. The criteria used was based upon the ASTM definition of a "positive" test being one that produces one or more of the following: (a) audible report (b) flame or visible light (c) definite evidence of smoke (not dust) and (d) definite evidence of sample discoloration, with the stipulation that if doubt exists, the trial result is to be called "negative".

DSC scans made on impact residues showed, in the case of pure fulminate that produced a negative fall hammer result, the exotherm peak area was very nearly the same as that obtained on the sample prior to impact testing but the peak temperatures were generally lower. In the case of the pure fulminate that produced a positive fall hammer result, the exotherm peak area was greatly reduced and the shape of the exotherm as well as peak temperatures were quite different from that obtained on the sample prior to impact testing. In one case, a third exotherm peak was found inserted between the doublet. This feature is never seen when the pure fulminate is examined.

It appears that with only a little more method development, the DSC method can be used to distinguish between a "positive" impact residue and a "negative" impact residue for pure mercury fulminate. 
All thermograms obtained on impact residues from samples of $10 \%$ mercury fulminate in caustic sludge deviated greatly from thermograms obtained on the same samples prior to impact testing. The most obvious difference is that the dominant, sharp endotherm peak that is usually found (at $225 \mathrm{C}$ ) in the caustic sludge void of fulminate is no-longer seen, but rather, a dominant, sharp endotherm is found at significantly higher temperatures. We don't know what to make of this. We believe that in order to develop a correlation between DSC results and the results of impact testing on sludge samples, further work is required: Particularly, DSC analysis of pre and.post drop hammer test residues of sludge (void of fulminate) is needed.

DSC analysis is complicated by the fact that the thermogram greatly depends upon the extent to which the fulminate sample is confined during the test. This dependence carries over to the way in which the sample pan is sealed and the type of pan used. It is the peak area and shape and not the peak temperature that is mostly effected. When comparing thermograms obtained using the same sample pan type, there is no difficulty encountered.

Both the caustic and neutral sludge samples void of fulminate produced thermograms containing endotherms only.

All sludge samples spiked with mercury fulminate produce exotherms in the DSC thermogram that are due to the presence of fulminate. The exotherms have peak temperatures that are shifted significantly downward from those observed on the pure mercury fulminate samples.

In the case of the neutral sludge, the exctherm peak area is roughly proportional to the amount of fulminate spiked into the sludge. In the case of the caustic sludge this is not the case. The fact that exotherm peak temperatures are not those observed on pure fulminate and that exotherm peak areas may depend upon the spiking level suggests that the exotherm observed on the sludge sample may not be simply the decomposition exotherm for mercury fulminate. It may for example result from a reaction between the fulminate and a sludge 
component. It must be noted that the exotherm is a doublet, whether sludge is present or not.

Mercury fulminate produced an exotherm in the Carius tube test with onset at $186 \mathrm{C}$. The Antoine plot shows the onset for permanent gas generation to be $186 \mathrm{C}$.

Mercury droplets are clearly present in the Carius tube at the end of the test in every case. When small sample sizes of sludge spiked with $10 \%$ (by weight) fulminate are tested ( 3.3 grams or less) no exotherm is detected, however, when larger ( $10 \mathrm{~g})$ sizes are tested, the exotherm is clear.

In the Carius tube test, the exotherm onset is found at $114 \mathrm{C}$ for the caustic sludge spiked with $10 \%$ fulminate. The Antoine plot shows the onset for pressure generation to be $142 \mathrm{C}$. The exotherm onset is found at $118 \mathrm{C}$ for the neutral sludge spiked with $10 \%$ fulminate, while the onset for permanent gas generation is found at $149 \mathrm{C}$. The major endotherms that are expected to result from the sludge components of the mixture are seen in the Carius tube thermograms.

The fact that the onset for permanent gas generation does not agree with the exotherm onset in the Carius tube test suggests that the exotherm is not due to mercury fulminate. The same suggestion was made after the close examination of DSC data (given above).

The size of the exotherm seen in the Carius tube test (in terms of peak height and width) is much greater for the caustic sludge sample than for the neutral sludge sample. This suggests that further study should be made on the effect of $\mathrm{pH}$ on the reaction exotherm. 


\section{SCOPE OF THE ASSESSMENT}

This assessment covers thermal screening, differential scanning calorimetry, and impact sensitivity testing on Mercury Fulminate, and mixtures of the fulminate in dry inorganic sludge, which is present in large quantities in a number of storage tanks at Westinghouse Savannah River.

The test matrix and conditions therein have been suggested by Westinghouse.

This work follows discussions between Mr. Lee Dworjanyn (Westinghouse Savannah River) and Mr. Richard Wedlich (Chilworth Technology, Inc.).

Safety in chemical manufacture and cleaning requires that all possible operational hazards are evaluated. A suitable basis for safe operation needs to be determined and implemented. Possible operational hazards include chemical reaction hazards and the presence and possible ignition of flammable atmospheres. 


\section{TEST OBJECTIVES}

The dropweight testing yields valuable information on the impact sensitivity of the sample material. Through analysis and interpretation, the data from the dropweight testing shows the amount of force the sample can withstand before detonation (when the force is delivered from a dropped weight). This test

. provides critical information for the safe mechanical removal of the sample from the storage tank, in the case where the solvent has evaporated and the sample remaining is a hard solid.

DSC was used to screen sludge formulations spiked with mercury fulminate for exothermic behavior. The onset temperature for any and all endotherms and exotherms, as well as the enthalpy change associated with the exotherms was determined on both pure fulminate and fulminate/sludge mixtures.

The Carius Tube or ICI 10 gram Closed Tube test is similar to the DSC, however permits the testing of a much larger sample. The Carius Tube testing measures the onset temperature of any thermal transition (endotherm or exotherm) and any concurrent gas evolution. It provides an estimate of the relative rate of sample self-heating and the actual volume and rate of gas evolved as the sample is scanned through a wide temperature range. 


\section{APPROACH}

\section{DIFFERENTIAL SCANNING CALORIMETRY (DSC)}

Thermograms are obtained on pure fulminate, pure caustic sludge and pure neutral sludge in order to characterize each. The characterization consists of making a determination of the onset temperature of each transition observed in the thermogram as well as a semi-quantitative determination of-the enthalpy change to accompany each transition.

The first consideration is to superposition the thermogram of fulminate atop either sludge thermogram. This is done in order to verify that there are no interfering endotherms or exotherms. That is, no peak appearing in the fulminate thermogram will be obscured by a peak that appears in the sludge thermogram by coincidence.

Next we will examine the effect of mixing fulminate with caustic sludge and with neutral sludge. Should there be no interaction between components we expect to find the fulminate exotherm peak at the same onset temperature and with the same enthalpy change after the peak area is integrated on a per gram fulminate basis. This assumes that the sludge component does not act as a severe thermal diluent and "wash out" the fulminate exotherm altogether.

Should there be a purely catalytic effect, we expect to find the fulminate exotherm shifted to lower onset temperature.

Should the fulminate react with a sludge component, we expect to find either the fulminate peak with a decreased peak area, or a new feature (endotherm or exotherm) not previously observed in the thermograms obtained on pure fulminate or sludge void of fulminate. In the former case the decreased heat release per gram fulminate (as 
compared to pure fulminate) is a result of consumption of fulminate in the sludge reaction.

\section{DROPWEIGHT TESTING}

Dropweight testing was performed on the pure Mercury Fulminate and fulminate-sludge mixtures as a means of assessing the how sensitive the sample is to impact energy.

By testing both pure $\mathrm{Hg}(\mathrm{ONC})_{2}$ and fulminate-sludge mixtures, one is able to rank the samples from most to least sensitive to detonation from impact energy. Should a low detonation energy for a pure fulminate sample be seen, great care must be taken in handling areas with a high concentration $\mathrm{Hg}(\mathrm{ONC})_{2}$. Although caution is advised, less sensitive care is required when dealing with fulminate-sludge mixtures that are able to withstand much higher impact energy.

All dropweight testing followed ASTM and equipment procedure guidelines. The protocol for testing and data analysis can be found in Appendix 1.

\section{CARIUS TUBE THERMAL ANALYSIS}

The approach taken to the Carius Tube testing is much the same as that of the DSC work.

Carius Tube Thermal Analysis is performed because it provides the added advantage of looking at sample quantities of a much larger size. In addition, any exothermic activity detected is now accompanied by an independent pressure measurement that can greatly aid in the determination of the reaction mechanism. 


\section{EXPERIMENTAL}

SAMPLE INFORMATION

$\begin{array}{lll}\text { Client } & : & \text { Westinghouse Savannah River Company } \\ \text { Sample } & : & \text { Mercury Fulminate } \mathrm{Hg}(\mathrm{ONC})_{2} \\ & 10 \% \text { Fulminate in Caustic Sludge } \\ & 10 \% \text { Fulminate in Neutral Sludge } \\ & 5 \% \text { Fulminate in Caustic Sludge } \\ & 5 \% \text { Fulminate in Neutral Sludge } \\ & & \text { Caustic Sludge - Lee Dworjanyn } \\ \text { Origin of Sample } & \text { Neutral Sludge - Lee Dworjanyn } \\ & & \text { Mercury Fulminate - Chilworth Technology } \\ \text { Sample Description } & \text { Sludge - fine dry tan powder some with } \\ & & \text { Fulminate - fine white powder (very pale } \\ & & \text { yellow tint) }\end{array}$

\section{PROCEDURE TO PREPARE SLUDGE}

Chilworth Technology received the sludge samples, both caustic and neutral, from Lee Dworjanyn at Westinghouse Savannah River. As well as the dried sludge samples, Chilworth also received a procedure for the preparation of Mercury Fulminate. After procuring the proper chemical components, fulminate synthesis began and was conducted in accordance with the provided procedure. A copy of the Mercury Fulminate preparation procedure can be found in Appendix 2. 
TEST MATRIX (as specified by vendor)

\begin{tabular}{|c|c|c|}
\hline Test & Number of Tests & Sample Composition \\
\hline$\overline{\mathrm{DSC}}$ & 1 & Caustic Sludge \\
\hline$\overline{\mathrm{DSC}}$ & 1 & Neutral Sludge \\
\hline$\overline{\mathrm{DSC}}$ & 2 & $\begin{array}{c}10 \% \text { (by weight) } \mathrm{Hg}(\mathrm{ONC})_{2} \text { in } \\
\text { Caustic Sludge }\end{array}$ \\
\hline$\overline{D S C}$ & 2 & $\begin{array}{c}10 \% \text { (by weight) } \mathrm{Hg}(\mathrm{ONC})_{2} \text { in } \\
\text { Neutral Sludge }\end{array}$ \\
\hline DSC & 2 & $\begin{array}{l}\text { Pure Mercury Fulminate } \\
\mathrm{Hg}(\mathrm{ONC})_{2}\end{array}$ \\
\hline Dropweight Test & 1 set & $\begin{array}{c}5 \% \text { (by weight) } \mathrm{Hg}(\mathrm{ONC})_{2} \text { in } \\
\text { Caustic Sludge }\end{array}$ \\
\hline Dropweight Test & 1 set & $\begin{array}{l}10 \% \text { (by weight) } \mathrm{Hg}(\mathrm{ONC})_{2} \text { in } \\
\text { Caustic Sludge }\end{array}$ \\
\hline Dropweight Test & 1 set & $\begin{array}{c}5 \% \text { (by weight) } \mathrm{Hg}(\mathrm{ONC})_{2} \text { in } \\
\text { Neutral Sludge }\end{array}$ \\
\hline Dropweight Test & 1 set & $\begin{array}{l}10 \% \text { (by weight) } \mathrm{Hg}(\mathrm{ONC})_{2} \text { in } \\
\text { Neutral Sludge }\end{array}$ \\
\hline Dropweight Test & 1 set & $\begin{array}{c}\text { Pure Mercury Fulminate } \\
\mathrm{Hg}(\mathrm{ONC})_{2}\end{array}$ \\
\hline Thermal Analysis & 1 & $\begin{array}{c}5 \% \text { (by weight) } \mathrm{Hg}(\mathrm{ONC})_{2} \text { in } \\
\text { Neutral Sludge }\end{array}$ \\
\hline Thermal Analysis & 1 & $\begin{array}{c}10 \% \text { (by weight) } \mathrm{Hg}(\mathrm{ONC})_{2} \text { in } \\
\text { Neutral Sludge }\end{array}$ \\
\hline Thermal Analysis & 1 & $\begin{array}{c}10 \% \text { (by weight) } \mathrm{Hg}(\mathrm{ONC})_{2} \text { in } \\
\text { Caustic Sludge }\end{array}$ \\
\hline
\end{tabular}




\section{DIFFERENTIAL SCANNING CALORIMETRY (DSC)}

\section{Test Apparatus}

Heat flow DSC.

\section{Calibration}

The differential scanning calorimeter was calibrated ḅefore any testing of Westinghouse samples took place. A baseline check was made by running an empty pan through the experimental temperature range. The resulting thermogram (Figure 1) shows the baseline slope to be virtually zero as desired. A calibration was performed by running a pure indium standard and using the resulting melting endotherm to check the instruments temperature and area calibrations. The resulting thermogram (Figure 2) shows that the instrument is well-calibrated since it returns a melting point of $156.7^{\circ} \mathrm{C}$ and a heat of fusion of $6.52 \mathrm{mcal} / \mathrm{mg}$, whereas the accepted literature values are $156.2^{\circ} \mathrm{C}$ and 6.8 $\mathrm{mcal} / \mathrm{mg}$, respectively.

\section{Test Procedure}

Caustic samples were run in copper DSC pans sealed with copper lids. All other samples were run in aluminum DSC pans sealed with aluminum lids. The typical sample weight was approximately $2 \mathrm{mg}$ for pure fulminate, $10 \mathrm{mg}$ for a pure sludge sample, and $15 \mathrm{mg}$ for mixtures of fulminate with sludge. Sample pans were sealed with ambient air in the pan, then placed in the DSC cell. The cell atmosphere was nitrogen that was continuously replaced at a rate of $40 \mathrm{ml} /$ minute.

The scan rate used was $20^{\circ} \mathrm{C} /$ minute and the samples were typically scanned from ambient temperature to no less than $300^{\circ} \mathrm{C}$. 


\section{DROPWEIGHT IMPACT SENSITIVITY TESTING}

\section{Test Apparatus}

The Dropweight Apparatus consists of a cast steel block with base, anvil, column, guides, dropweights, release device and impact device. The dropweight test apparatus is shown fully as a diagram in Appendix 6. Dropweights of different masses - 1, 2, 5 and $10 \mathrm{~kg}$-- can be attached to the column and guides and by varying the weights and the height from which they are dropped; the:impact energy can be varied from $1 \mathrm{~J}$ through to $60 \mathrm{~J}$.

The sample substance being tested is enclosed in a sample cell consisting of two co-axial steel cylinders, one above the other in a hollow cylindrical steel guide ring. The cylinders are steel rollers from roller bearings with polished surfaces and rounded edges. The sample cell is placed on the intermediate anvil and centered.

\section{Calibration}

No calibration of the Dropweight Test Apparatus was conducted.

\section{Test Procedure}

The test performed was conducted on five different samples: a pure mercury fulminate, $10 \%$ mercury fulminate in caustic sludge, $10 \%$ mercury fulminate in neutral sludge, $5 \%$ mercury fulminate in caustic sludge, and 5\% mercury fulminate in neutral sludge. All tests were performed in accordance with ASTM E 680-79: Standard Test Method for Drop Weight Impact Sensitivity of Solid-Phase Materials. The data and observations were based on the guidelines set forth in ASTM E 680-79. The test procedure followed was provided with the test apparatus and follows standards to meet the requirements of the Bureau of Mines. Both bodies of literature used to perform the test and to analyze the data can be found in Appendix 1. 
A sample is taken with a scoop of $40 \mathrm{~mm}^{3}$. The substance is then placed in the open sample cell, which is already in the locating ring on the intermediate anvil. The upper steel cylinder is then set to be $1 \mathrm{~mm}$ above the lower cylinder and is held in that position by means of an O-ring.

When the sample cell is properly positioned, the dropweight is released and the impact result is observed. Distinction is made between "no reaction", "decomposition" (change of color), and "explosion".(crackling;:sparkling;:or inflammation).

The series of trials is started with a single trial at $10 \mathrm{~J}$. If an "explosion" is observed, the series is continued with trials for decreasing impact energies until a "decomposition" result or "no reaction" result is observed. If however, a "decomposition" result or "no reaction" result is observed at $10 \mathrm{~J}$, the weight is slowly increased until an "explosion" result is observed or the maximum impact energy is reached $(60 \mathrm{~J})$.

The limiting impact energy for a substance, is defined as the lowest energy for.which an "explosion" result is obtained from at least one out of the six trials. The UN Recommendations indicate that a substance is too sensitive for transport if it exhibits a limiting impact energy of 2 Joules or less. The dropweight test apparatus essentially consists of a weight of known mass suspended, via an electromagnet, above an anvil or striking surface anchored to a large, heavy steel block. The entire assembly is supported by steel supports and guide rails. A sample of known mass is charged to the impact device and placed on the anvil. The dropweight is raised manually to a desired, recorded height and released by disarming the magnet. 


\title{
CARIUS TUBE THERMAL ANALYSIS
}

\section{Test Apparatus}

\begin{abstract}
A Carius tube (35 milliliters) with a re-entrant thermocouple pocket and adapter with a glass/metal joint on the outlet is connected via a stainless steel tube with a capillary bore to transmit pressure to a calibrated 70 bar pressure transiducer in a cooled area.
\end{abstract}

The Carius tube is situated in a furnace, which can withstand rupture of the tube and burning of contents and the temperature is ramped at $0.5^{\circ} \mathrm{C} \cdot \min ^{-1}$.

Microprocessor data logging has the flexibility to cope with a wide range of gas pressure and temperature within an experiment and gives accurate data of rapid pressure generation.

A diagram of the Carius Tube Test Apparatus can be seen in Appendix 6.

\section{Calibration}

The Carius Tube Test Apparatus was calibrated before any testing of Westinghouse samples took place. A calibration was performed by running a pure indium standard and using the resulting melting endotherm to check the instruments temperature and area calibrations. The resulting thermogram (Figure 2B) shows that the instrument is wellcalibrated since it returns a melting point of $157.5^{\circ} \mathrm{C}$ and $159^{\circ} \mathrm{C}$, whereas the accepted literature value is $156.2^{\circ} \mathrm{C}$.

\section{Test Procedure}

All Carius Tube testing follows the ABPI 6.3 Closed Tube Test Guidelines for Chemical Reaction Hazard Evaluation. The sample was prepared by weighing the sludge into a crucible, adding the desired amount of fulminate ( $10 \%$ based on the total charge), mixing and charging the mix to the Carius tube. Per the standard Carius tube procedure the sample 
was heated in an oven from ambient temperature to $400.0^{\circ} \mathrm{C}$ at a rate of $0.5^{\circ} \mathrm{C} \cdot \mathrm{min}^{-1}$ in order to screen for exothermic activity and search for non-condensable gas generation. In the Mercury Fulminate run the sample was charged directly to the Carius tube and the standard procedure was followed. 


\section{RESULTS}

\section{DSC RESULTS}

\section{Neutral Sludge}

The neutral sludge produced the thermogram shown in Figure 3: Only endothermic transitions are observed as the sample is heated from ambient to $450^{\circ} \mathrm{C}$. A sharp endotherm with peak at $267^{\circ} \mathrm{C}$ is indicative a melting transition. The broad endotherms with peaks at $163^{\circ} \mathrm{C}$ and $220^{\circ} \mathrm{C}$ could be melting endotherms that are broadened by the colligative effect of a dissolved impurity or vaporization. Figure 4 is the thermogram produced by a second trial. Again, we find endotherm peaks at $265^{\circ} \mathrm{C}, 227^{\circ} \mathrm{C}$ and $164^{\circ} \mathrm{C}$. This analysis shows that the reproducibility of the method on neutral sludge samples is very good.

\section{Caustic Sludge}

The caustic sludge produced the thermogram shown in Figure 5: Only endothermic transitions are observed. The large, sharp endotherm with peak at $226^{\circ} \mathrm{C}$ is probably a melting endotherm. Small endotherms are also found with peaks at $97^{\circ} \mathrm{C}$ and $165^{\circ} \mathrm{C}$. The thermogram shown in Figure 6 was obtained in the second trial: Again, a sharp endotherm with peak at $227^{\circ} \mathrm{C}$ is the dominant feature. A small endotherm is found with peak at $166^{\circ} \mathrm{C}$. The very tiny endotherm found in the first trial at $97^{\circ} \mathrm{C}$ is not seen in the - second trial. This analysis shows that the reproducibility of the method on caustic sludge samples is very good.

\section{Mercury Fulminate}

The pure fulminate sample was subjected to multiple DSC analysis. It was decided along with the customer that the caustic sludge samples would be run in copper pans since they may react with aluminum. The neutral sludge samples were run in aluminum pans. It must be pointed out that in the DSC technique, the sample pan is always referenced to an empty reference pan made of the same material. This procedure minimizes certain pan effects. 


\section{Run made in a Sealed Aluminum Pan}

Figure 7 is the thermogram obtained on pure fulminate sealed in an aluminum pan. Two well-resolved exothermic peaks are found with peak temperatures $237^{\circ} \mathrm{C}$ and $245^{\circ} \mathrm{C}$, respectively. The total peak area is $-55.54 \mathrm{mcal} / \mathrm{mg}$. A second trial was made and the results are given in Figure 8: Again, two exothermic peaks with temperatures $232^{\circ} \mathrm{C}$ and $242^{\circ} \mathrm{C}$ were found. This time the peak area was $-54.71 \mathrm{mcal} / \mathrm{mg}$. There is good agreement between trials.

When the same fulminate is run in a copper pan, the resulting thermogram resembles Figure 9: Again, two peaks are found at $230^{\circ} \mathrm{C}$ and $243^{\circ} \mathrm{C}$, respectively. This time the peak area is quite reduced, being only $-25.96 \mathrm{mcal} / \mathrm{mg}$. The second trial is shown in Figure 10. The peak temperatures are $229^{\circ} \mathrm{C}$ and $244^{\circ} \mathrm{C}$ and the peak area is -35.85 $\mathrm{mcal} / \mathrm{mg}$.

\section{Run made in a Crimped Aluminum Pan}

One difference between copper and aluminum sample pans is the way each is sealed. We sealed an aluminum pan in a manner similar to sealing of a copper pan. The resulting fulminate thermogram (Figure 11) shows two peaks at $230^{\circ} \mathrm{C}$ and $242^{\circ} \mathrm{C}$, respectively and a peak area of $-21 \mathrm{mcal} / \mathrm{mg}$. These results are very similar to results obtained using copper pans and suggest that the method of sealing and resulting extent of confinement has an effect on the peak area observed.

\section{Run made in a Vented Aluminum Pan}

Figure 12 is the thermogram produced by fulminate when run in a vented pan. This pan lid was intentionally punctured with a fine needle to produce a pinhole. Now only one peak is observed (at $234^{\circ} \mathrm{C}$ ) and the peak area is $-33.51 \mathrm{mcal} / \mathrm{mg}$. 
These data suggest that there may not be as good agreement between trials made in copper pans as there is between trials made in aluminum pans. This is due to the fact that our ability to reproduce the peak area depends our ability to reproduce the quality of the pan seal - The aluminum pans simply are easier to reproducibly seal.

Since our main concern is not with determination of absolute values for decomposition energy but rather with studying the influence of the sludge matrix on the fulminate decomposition exotherm, the copper pans are adequate.

\section{Neutral Sludge Spiked with Mercury Fulminate}

The thermogram shown in Figure 13 was obtained on a neutral sludge sample spiked with $5 \%$ by weight mercury fulminate. The run was made in a sealed aluminum pan. Three endothermic peaks are found. The peak temperatures $\left(159^{\circ} \mathrm{C}, 222^{\circ} \mathrm{C}\right.$ and $\left.256^{\circ} \mathrm{C}\right)$ agree well with those found on the sludge void of fulminate. An exotherm with peak at $180^{\circ} \mathrm{C}$ is found that is not present in the thermogram obtained on sludge void of fulminate. This exotherm must be due to fulminate and it is the only exotherm found.

Figure 14 is a composite of thermograms obtained on the pure sludge, sludge with $5 \%$ and sludge with $10 \%$ (by weight) mercury fulminate. Notice that the fulminate peak is clearly at $180^{\circ} \mathrm{C}$. The peak area for the $5 \%$ sample is $-3.06 \mathrm{mcal} / \mathrm{mg}$ and for the $10 \%$ sample it is $-5.62 \mathrm{mcal} / \mathrm{mg}$. These areas are normalized to the total sample weight. When corrected for the weight $\%$ fulminate they become $-61.2 \mathrm{mcal} / \mathrm{mg}$ and $-56.2 \mathrm{mcal} / \mathrm{mg}$, respectively. A second trial was performed on both the $5 \%$ fulminate mixture and $10 \%$ fulminate mixture with neutral sludge. In the former case the peak area normalized to the $\mathrm{mg}$ of fulminate was $-52.5 \mathrm{mcal} / \mathrm{mg}$. In the later case, it was $-52.6 \mathrm{mcal} / \mathrm{mg}$. There is good agreement between trials in both cases.

The peak temperature is approximately $60^{\circ} \mathrm{C}$ lower than any peak temperature found in the thermograms on pure fulminate. On a per mg fulminate basis, the reaction heats are not very different from the values obtained when pure fulminate is run. 


\section{Caustic Sludge Spiked with Mercury Fulminate}

Figure 15 is a composite of thermograms obtained on the pure sludge, sludge with $5 \%$ and sludge with $10 \%$ (by weight) mercury fulminate. Notice that the fulminate peaks are clearly at $181^{\circ} \mathrm{C}$ and $192^{\circ} \mathrm{C}$. These peaks must be due to fulminate sinoe the sludge by itself does not produce them. Two endotherms with peaks at $165^{\circ} \mathrm{C}$ and $226^{\circ} \mathrm{C}$ are found. These peak temperatures are exactly those found when the sludge void of fulminate is run.

Figures 16 and 17 show the exothermic peaks (in close-up view) obtained in trials one and two made on the $5 \%$ fulminated mixture. The peak areas are $-3.44 \mathrm{mcal} / \mathrm{mg}$ and -3.74 $\mathrm{mcal} / \mathrm{mg}$ for trials one and two, respectively. When these areas are calculated on a per $\mathrm{mg}$ of fulminate basis they become -68.8 and $-74.8 \mathrm{mcal} / \mathrm{mg}$ fulminate, respectively.

The peak temperatures are approximately $60^{\circ} \mathrm{C}$ lower than any peak temperature found in the thermogram obtained on pure fulminate. The peak areas are larger (by approximately $30 \%$ ) when calculated on a per mg of fulminate basis then the peaks obtained on pure mercury fulminate.

Figures 18 and 19 show the exotherms produced by fulminate in the caustic sludge when spiked to a level of $10 \%$ by weight (trials one and two). The peak temperatures the same as those found for the $5 \%$ by weight mixture. The peak areas on a per mg of fulminate basis are -101.1 and $-103.0 \mathrm{mcal} / \mathrm{mg}$, respectively.

The peak areas are not proportional to the weight percentage of fulminate in the case of the caustic sludge. 


\section{Mercury Fulminate Residue from Drop Hammer Test}

Figure 20 shows the thermogram produced by the material recovered from a drop hammer test that produced a negative (no ignition) drop hammer test result. The hammer was dropped from $20 \mathrm{~cm}$. Notice that although the peak area $(-53.20 \mathrm{mcal} / \mathrm{mg})$ is very similar to that obtained on mercury fulminate samples and the peak temperatures $\left(221^{\circ} \mathrm{C}\right.$ and $245^{\circ} \mathrm{C}$ ) are also very similar to the expected fulminate peak temperatures.

Figure 21 shows the thermogram produced by the material recovered from a drop hammer test that produced a negative (no ignition) drop hammer test result. The hammer was dropped from $120 \mathrm{~cm}$. Notice that although the peak area $(-55.24 \mathrm{mcal} / \mathrm{mg})$ is very similar to that obtained on mercury fulminate samples and the peak temperatures $\left(228^{\circ} \mathrm{C}\right.$ and $246^{\circ} \mathrm{C}$ ) are also very similar to the expected fulminate peak temperatures.

Figure 22 shows the thermogram produced by the material recovered from a drop hammer test that produced a positive (ignition) drop hammer result. The hammer was dropped from $126 \mathrm{~cm}$. Notice that the upper peak is found at $245^{\circ} \mathrm{C}$ where we expect a fulminate peak but the lower peak is found at $219^{\circ} \mathrm{C}$, which is around $12^{\circ} \mathrm{C}$ lower than where we expect a fulminate peak. Notice also that the peak area is $-41.31 \mathrm{mcal} / \mathrm{mg}$, which is only around $75 \%$ of the peak area expected from fulminate.

Figure 23 shows the thermogram produced by the material recovered from a drop hammer test that produced a positive (ignition) drop hammer result. The hammer was dropped from $125 \mathrm{~cm}$. Notice that the upper peak is found at $240^{\circ} \mathrm{C}$, which is $5^{\circ} \mathrm{C}$ lower than the expected fulminate peak and the lower peak is found at $211^{\circ} \mathrm{C}$, which is around $20^{\circ} \mathrm{C}$ lower than where we expect a fulminate peak. Notice also that the two peaks are well resolved with a third, smaller peak between them. This feature was not seen in any of the 6 fulminate thermograms or in either of the 2 thermograms produced by residue taken from 
negative drop hammer fulminate tests. Finally, we note that the combined peak areas don't amount to more than $20 \%$ of the peak area expected from mercury fulminate.

Figure 24 shows the thermogram produced by caustic sludge spiked with $10 \%$ mercury fulminate. The temperature axis is scaled to go from $0^{\circ} \mathrm{C}$ to $400^{\circ} \mathrm{C}$.

Figure 25 shows (on the same temperature scale as Figure 24) the thermogram produced by the sample (caustic sludge spiked:with $10 \%$ mercury fulminate) after it was subjected to a fall hammer test. In the fall hammer test the hammer was dropped from $270 \mathrm{~cm}$ and the result was considered negative (no ignition). Notice that the doublet peak, which we associate with fulminate is absent or greatly diminished. Notice also that the large endotherm, which we expect to obtain with caustic sludge at $226^{\circ} \mathrm{C}$ is not present but rather a large endotherm at $277^{\circ} \mathrm{C}$ is found, which is not found in the normal caustic sludge.

Figure 26 shows the thermogram we obtained when we repeated the analysis: A second sample of caustic sludge spiked with $10 \%$ mercury fulminate was subjected to the drop. hammer test. The hammer was dropped from $270 \mathrm{~cm}$ and the test result was deemed negative (no ignition). The residue was recovered and subjected to DSC analysis to produce the thermogram of interest. Notice that there is a small exotherm with peak $\overline{\mathrm{at}}$ $184^{\circ} \mathrm{C}$, which corresponds to a fulminate peak. Notice also that the endotherm peak is now at $249^{\circ} \mathrm{C}$. 
DSC RESULTS (continued) :

\begin{tabular}{|c|c|c|c|c|c|c|}
\hline Sample ID & Pan Type & Trial & $\begin{array}{l}\text { Thermal } \\
\text { Activity }\end{array}$ & $\begin{array}{c}\mathbf{T}_{\text {PEAK }} \\
\left({ }^{\circ} \mathrm{C}\right)\end{array}$ & $\begin{array}{c}\Delta \mathbf{H} \\
\text { (mcal } / \mathrm{mg} \text { of } \\
\text { Fulminate) }\end{array}$ & $\begin{array}{c}\Delta \mathbf{H} \\
\text { (mcal/mg of } \\
\text { sample) }\end{array}$ \\
\hline Pure Fulminate & $\begin{array}{c}\text { Sealed } \\
\text { Aluminum }\end{array}$ & $\begin{array}{l}1 \\
2 \\
\end{array}$ & $\begin{array}{l}\text { Exotherm } \\
\text { Exotherm }\end{array}$ & $\begin{array}{l}237,245 \\
232,242 \\
\end{array}$ & $\begin{array}{l}-55.54 \\
-54.71 \\
\end{array}$ & - \\
\hline Pure Fulminate & $\begin{array}{l}\text { Crimped } \\
\text { Copper }\end{array}$ & $\begin{array}{l}1 \\
2\end{array}$ & $\begin{array}{l}\text { Exotherm } \\
\text { Exotherm }\end{array}$ & $\begin{array}{l}230,243 \\
229,244\end{array}$ & $\begin{array}{l}-25.96 \\
-35.85\end{array}$ & - \\
\hline Pure Fulminate & $\begin{array}{c}\text { Crimped } \\
\text { Aluminum }\end{array}$ & 1 & Exotherm & 230,242 & -21.00 & - \\
\hline Pure Fulminate & $\begin{array}{c}\text { Vented } \\
\text { Aluminum }\end{array}$ & 1 & Exotherm & 234 & -33.51 & - \\
\hline $\begin{array}{c}\text { Neutral Sludge w/ } \\
5 \% \text { Fulminate }\end{array}$ & $\begin{array}{c}\text { Sealed } \\
\text { Aluminum }\end{array}$ & $\begin{array}{c}1 \\
1,2 \\
\end{array}$ & $\begin{array}{l}\text { Endotherm } \\
\text { Exotherm }\end{array}$ & $\begin{array}{c}159,222,256 \\
180\end{array}$ & $\begin{array}{l}-61.20 \\
-52.50 \\
\end{array}$ & -3.06 \\
\hline $\begin{array}{c}\text { Neutral Sludge w/ } \\
10 \% \text { Fulminate }\end{array}$ & $\begin{array}{c}\text { Sealed } \\
\text { Aluminum }\end{array}$ & $\begin{array}{c}1 \\
1,2 \\
\end{array}$ & $\begin{array}{l}\text { Endotherm } \\
\text { Exotherm }\end{array}$ & 180 & $\begin{array}{l}-56.20 \\
-52.60 \\
\end{array}$ & -5.62 \\
\hline $\begin{array}{c}\text { Caustic Sludge w/ } \\
5 \% \text { Fulminate }\end{array}$ & $\begin{array}{c}\text { Sealed } \\
\text { Aluminum }\end{array}$ & $\begin{array}{c}1 \\
1,2 \\
\end{array}$ & $\begin{array}{l}\text { Endotherm } \\
\text { Exotherm }\end{array}$ & $\begin{array}{l}165,226 \\
181,192\end{array}$ & $\begin{array}{l}-68.80 \\
-74.80 \\
\end{array}$ & $\begin{array}{l}-3.44 \\
-3.74\end{array}$ \\
\hline $\begin{array}{c}\text { Caustic Sludge w/ } \\
10 \% \text { Fulminate }\end{array}$ & $\begin{array}{c}\text { Sealed } \\
\text { Aluminum }\end{array}$ & $\begin{array}{c}1 \\
1,2\end{array}$ & $\begin{array}{l}\text { Endotherm } \\
\text { Exotherm }\end{array}$ & $\begin{array}{c}225 \\
181,192\end{array}$ & $\begin{array}{l}-101.10 \\
-103.00\end{array}$ & $\begin{array}{l}-10.11 \\
-10.30\end{array}$ \\
\hline
\end{tabular}




\section{DROPWEIGHT TEST RESULTS :}

Test Purpose

Test Apparatus

Test Standard

Date of Test

Analyst
To determine the impact sensitivity energy the sample is able to withstand without detonation

Dropweight tester in accordance with Bureau of Mines regulation ASTM Ë 680-79

$03.03 .99-03.05 .99$

B. Carey

\section{Pure Mercury Fulminate}

\begin{tabular}{|c|c|c|c|c|c|}
\hline $\begin{array}{c}\text { Drop } \\
\text { Height } \\
(\mathrm{cm})\end{array}$ & (go) & X & i & in & $\mathbf{i}^{2} \mathbf{n}$ \\
\hline 125 & 7 & 0 & 2 & 0 & 0 \\
\hline 100 & 6 & 4 & 1 & 4 & 4 \\
\hline 80 & 0 & 6 & 0 & 0 & 0 \\
\hline TOTAL & 13 & 10 & & 4 & 4 \\
\hline & & & & A $)$ & B \\
\hline
\end{tabular}

Where:

$\operatorname{MEAN}(\mathrm{m})=\mathrm{c}+\mathrm{d}(\mathrm{A} / \mathrm{N}$ +or- $1 / 2)$

c $\quad=\log$ of lowest test height at which the less frequent event occurred (ex. 65)

d $\cdot \quad=$ interval between levels

$\mathrm{n}$ = number of "go" or "no go" at a particular height

$\mathrm{N} \quad=$ total number of trial per test

$\mathrm{i} \quad=$ multiplier index ( $\mathrm{i}=0$ for $\mathrm{c}, \mathrm{i}=1$ for $\mathrm{c}+\mathrm{d}$, etc.)

A $\quad=\Sigma$ in, $N=\Sigma \mathrm{n}$

B $\quad=\Sigma i^{2} n$

Therefore :

$\operatorname{MEAN}(\mathrm{m})=81.68 \mathrm{~cm}$ 
DROPWEIGHT TEST RESULTS (continued):

MAX HEIGHT OF TEST APPARATUS $\mathbf{2} \mathbf{2 . 7}$ meters

For test conditions: $\quad 10 \%$ Fulminate in Neutral Sludge -9 of 10 trials resulted in

"no go" at max height

10\% Fulminatejin Caustic Sludge - No positive results after 10 trials at max height

$5 \%$ Fulminate in Neutral Sludge - No positive results after 10 trials at max height

$5 \%$ Fulminate in Caustic Sludge - No positive results after 10 trials at max height

Note: See Appendix for original data sheets including all test trials. 


\section{CARIUS TUBE TEST RESULTS:}

Test Purpose

Test Apparatus

Test Standard

Date of Test

Analyst
:

:
To determine onset temperature for any exotherm and determine the temperature of permanent gas generation

Closed Tube Test Apparatus with oven and microprocessor

ABPI 6.3 Closed Tube Test

See Table

S. Ferguson

\begin{tabular}{|c|c|c|c|c|c|c|}
\hline Sample Name & $\begin{array}{c}\text { Test } \\
\text { Date }\end{array}$ & $\begin{array}{c}\text { File Name. } \\
\text { *.TXT }\end{array}$ & $\begin{array}{c}\text { W }_{\mathrm{f}} \\
\text { (grams) }\end{array}$ & $\begin{array}{c}\mathrm{W}_{\mathrm{s}} \\
\text { (grams) }\end{array}$ & $\begin{array}{c}\text { TW } \\
\text { (grams) }\end{array}$ & Initial Appearance \\
\hline $\begin{array}{c}\text { Mercury } \\
\text { Fulminate }\end{array}$ & $3 / 8 / 99$ & CWE1965g/h & 2.37 & - & 2.37 & Yellow powder \\
\hline $\begin{array}{c}10 \% \text { MF in CS } \\
\text { (run 1) }\end{array}$ & $3 / 4 / 99$ & CWE1965a/b & 0.3026 & 2.9 & 3.2026 & $\begin{array}{c}\text { Gray powder w/ } \\
\text { yellow specks }\end{array}$ \\
\hline $\begin{array}{c}10 \% \text { MF in NS } \\
\text { (run 2) }\end{array}$ & $3 / 5 / 99$ & CWE1965e/f & 0.3067 & 3.0 & 3.3067 & $\begin{array}{c}\text { Gray/brown powder } \\
\text { with yellow specks }\end{array}$ \\
\hline $\begin{array}{c}10 \% \text { MF in CS } \\
\text { (run 3) }\end{array}$ & $3 / 16 / 99$ & CWE1905a/b & 1.020 & 9.19 & $\mathbf{1 0 . 2 1 0}$ & $\begin{array}{c}\text { Gray powder with } \\
\text { yellow specks }\end{array}$ \\
\hline $\begin{array}{c}10 \% \text { MF in NS } \\
\text { (run 4) }\end{array}$ & $3 / 17 / 99$ & CWE1905c/d & 0.991 & 8.919 & $\mathbf{9 . 9 1 0}$ & $\begin{array}{c}\text { Gray/brown powder } \\
\text { with yellow specks }\end{array}$ \\
\hline
\end{tabular}

\begin{tabular}{|c|c|c|c|}
\hline \multirow[t]{2}{*}{ Sample Name } & \multicolumn{2}{|c|}{ Data on Maior Exotherm } & \multirow[t]{2}{*}{ Final Appearance } \\
\hline & $\begin{array}{l}\text { Tonset }_{\text {on }} \\
\left({ }^{\circ} \mathrm{C}\right) \\
\end{array}$ & $\begin{array}{l}\mathbf{P}_{0} \text { gis } \\
\left({ }^{\circ} \mathrm{C}\right) \\
\end{array}$ & \\
\hline Fulminate & 186.34 & 185.57 & $\begin{array}{l}\text { Orange/brown solid w/ small } \\
\text { mercury droplets }\end{array}$ \\
\hline $\begin{array}{c}10 \% \text { MF in CS } \\
\text { (run 1) }\end{array}$ & N/D & $\overline{140.1}$ & N/D \\
\hline $\begin{array}{l}10 \% \mathrm{MF} \text { in NS } \\
\text { (run 2) }\end{array}$ & $\mathrm{N} / \mathrm{D}$ & 140.1 & $\begin{array}{l}\text { Brown powder solid w/ traces } \\
\text { of mercury }\end{array}$ \\
\hline $\begin{array}{l}\text { 10\% MF in CS } \\
\text { (run 3) }\end{array}$ & 114.63 & 141.96 & $\begin{array}{l}\text { Gray powder solid w/ traces of } \\
\text { mercury; glass tube - hazy }\end{array}$ \\
\hline $\begin{array}{l}10 \% \mathrm{MF} \text { in NS } \\
\text { (run 4) }\end{array}$ & 117.57 & 148.79 & $\begin{array}{l}\text { Brown powder solid w/ traces } \\
\text { of mercury }\end{array}$ \\
\hline
\end{tabular}

N/D - No exotherm determined due to small sample size 
CARIUS TUBE TEST RESULTS (continued):

\begin{tabular}{|c|c|c|c|c|}
\hline Sample Name & $\begin{array}{l}\mathrm{T}^{0} \\
\left({ }^{\circ} \mathrm{C}\right)\end{array}$ & $\begin{array}{l}\mathbf{T}^{0} / \text { gram } \\
\left({ }^{\circ} \mathrm{C} / \mathrm{min} . \mathrm{g}\right)\end{array}$ & Relative Rates & $\begin{array}{c}\mathbf{T}_{\mathrm{F}} \\
\left({ }^{\circ} \mathrm{C}\right)\end{array}$ \\
\hline Mercury Fulminate & $538.46 @ 212.2^{\circ} \mathrm{C}$ & 227.19 & 1 & 240.0 \\
\hline $\begin{array}{l}10 \% \text { MF in CS } \\
\text { (run 1) }\end{array}$ & - & - & - & - \\
\hline $\begin{array}{l}10 \% \text { MF in NS } \\
\text { (run 2) }\end{array}$ & - & - & - & - \\
\hline $\begin{array}{l}10 \% \text { MF in CS } \\
\text { (run 3) }\end{array}$ & $2.27 @ 138.09^{\circ} \mathrm{C}$ & 2.23 & .0098 & 149.8 \\
\hline $\begin{array}{l}10 \% \text { MF in NS } \\
\text { (run 4) }\end{array}$ & $\leq 0.05$ & 0.05 & .0002 & 131.7 \\
\hline
\end{tabular}

Note : There were no deviations from standard test and/or equipment.

The temperature ramp rate was 、 $0.5 \mathrm{~K} \cdot \mathrm{min}^{-1}$

\section{Legend:}

MF Mercury Fulminate

CS Caustic Sludge

NS Neutral Sludge

$W_{f} \quad$ Weight of fulminate

$\mathrm{W}_{\mathbf{s}} \cdot$ Weight of sludge

TW Total sample weight

$T_{\text {onset }}$ Exotherm onset temperature

$\mathrm{T}^{0} \quad$ Peak Rate of Temperature rise

$\mathrm{T} / \mathrm{g}$ Peak Rate of Temperature rise per gram Mercury Fulminate

$P_{0 \text { gas }}$ Onset of Permanent Gas Generation

$T_{F} \quad$ Final Temperature Reached During Exotherm 


\section{DISCUSSION}

\section{DROPWEIGHT TEST}

The examination of pure Mercury Fulminate, with regard to its sensitivity to impact energy, yielded expected results. A definitive value for Mercury Fulminate, a known explosive, was obtained through dropweight testing. A critical height is obtained from which more than fifty percent of the trials result in a "go". A "go" or positive result is a detonation of the test sample: when the force from the dropweight strikes the intermediate anvil and sample cup. Detonation criteria is defined specifically in the ASTM E 680-79. Detonation criteria includes any of the following: audible report, flame or visible light, definite evidence of smoke, or definite evidence of discoloration of sample due to decomposition. The standard suggests if doubt exists, the trial should be considered a non-reaction. This text can be found in Appendix 1, ASTM E 680-79, Section 10 - Reaction Detection.

The determination of the impact sensitivity is based upon the equation:

$$
\mathbf{E}=\mathbf{m g h}
$$

Where:

$$
\mathrm{E} \text { is defined as the ENERGY (in Joules) }
$$

$\mathrm{m}$ is defined as the MASS (in Kilograms) $=2 \mathrm{Kg}$

$\mathrm{g}$ is defined as the Acceleration due to gravity $=9.8 \mathrm{~m} / \mathrm{s}^{2}$

$\mathrm{h}$ is defined as the DropHeight (in meters) $=$ varies

Although pure Mercury Fulminate is sensitive to impact energy as tested, the other sample conditions examined (fulminate concentrations with sludge) were not found to be sensitive to impact energy within the parameters of the test equipment. The maximum height of from which the dropweight could be released was 2.7 meters. The maximum height corresponds with a value of 52.9 Joules. For each condition there were 10 repetitions to confirm a nonreaction. Therefore, the impact energy of the fulminate-sludge mixtures is much larger than that of pure fulminate. It can be concluded that the sludge, regardless of type, serves as a buffer and raises the energy required to detonate Mercury Fulminate.

Samples taken from both "go" and "no go" trials were analyzed via differential scanning calorimetry. 


\section{DSC AND CARIUS TUBE}

$\underline{\text { DSC }}$

Fulminate exotherms are found in all sludge samples tested be they made with neutral or caustic sludge or spiked at the $5 \%$ or $10 \%$ (by weight) fulminate level. They are easily identified since neither sludge produces an exotherm on its own.

In the case of the neutral sludge, the observed fulminate exotherm has associated the same enthalpy change as pure fulminate: The experimental peak area is divided by the actual amount of fulminate in the test sample mixture to obtain mcal/ $\mathrm{mg}$ fulminate. When this is done the same value is obtained that is obtained with pure mercury fulminate. This suggests that all of the fulminate is consumed in this exotherm. Furthermore, the peak shape (a doublet) is the same as that observed from pure fulminate.

The doublet peak temperatures are shifted to significantly lower values from those observed on the pure fulminate samples. This temperature shift suggests that a sludge component might catalyze the fulminate decomposition. Another possible explanation is that the doublet exotherm of interest results not from fulminate decomposition but rather from an exothermic reaction between . fulminate and a sludge component. If that were the case, we would expect to find the normalized peak area to be the same for all spike levels up to the level that corresponds with a stoichiometric amount of fulminate. Once the spike level is sufficiently large to provide the reaction with an excess of fulminate, the normalized peak area will decrease owing to the fact that the maximum enthalpy change is obtained with the stoichiometric amount of fulminate and any excess fulminate simply decreases the $\mathrm{mcal} / \mathrm{mg}$ fulminate ratio.

Although the neutral sludge produces on its own 3 distinct endotherms in the thermogram, we don't believe that any of these interfere with the observations on the fulminate component. 
In the case of the caustic sludge, we again find a doublet of exothermic peaks and associate these with fulminate since the caustic sludge produces no exotherm on its own. Again, this doublet appears at significantly lower ternperature that its position in the thermogram obtained on the pure fulminate. Unlike the peak areas found in the neutral sludge matrix, the enthalpy change associated with fulminate in caustic sludge is not constant but changes from around $-72 \mathrm{mcal} / \mathrm{mg}$ fulminate (produced with the $5 \%$ spike) to around $-102 \mathrm{mcal} / \mathrm{mg}$ fulminate (produced with the $10 \%$ spike). The fact that it is not constant suggests that the exotherm is not due simply to fulminate decomposition.

\section{Carius. Tube}

The pure fulminate sample produced an exotherm at $185 \mathrm{C}$. The Antoine plot shows that the onset for permanent gas generation is $186 \mathrm{C}$. The exotherm onset temperature by this method is approximately 50 degrees lower than the value obtained by DSC. This is expected and is due to the fact that a 10 gram sample is tested as opposed to a $10 \mathrm{mg}$ sample.

The exotherm onset for the $10 \%$ fulminate in neutral sludge mixture is $115 \mathrm{C}$. The onset for pressure generation does not correspond to the exotherm but rather is found at $142 \mathrm{C}$. The exotherm onset for the $10 \%$ fulminate in caustic sludge mixture is $117 \mathrm{C}$. Again, the onset for pressure generation does not correspond to the exotherm but rather is found at $149 \mathrm{C}$. There is no significant pressure increase associated with the exotherms found in the Carius tube tests on fulminate mixtures with sludge, but rather a rise of approximately 3 barg.

We believe that the only source for permanent gas is fulminate decomposition. That the pressure onset is separated from the exotherm onset by as many as $32 \mathrm{C}$ (for fulminate in sludge), suggests that the exotherm is not due to a fulminate decomposition but rather a reaction between the fulminate and a sludge component. This interpretation is consistent with the interpretation given to the DSC results. 


\section{SUGGESTION FOR FURTHER TESTING}

It appears that mercury fulminate is "desensitized" by the presence of the diluent sludge since no mixture of fulminate with sludge produced a positive Dropweight test and no such mixture produced a significantly (>300 J/g) large heat of decomposition value.

All tests reported in the present study, however, were condücted on small ( $<10$ gram) sample sizes and the effect of the scale of the test has:not been determined.

Large scale tests are recommended. These can be broken down into tests to determine the initiation characteristics of the potential explosive and tests to determine its propagation characteristics. The detonation of condensed substances can be characterized by a number of properties, hence there are a large number of such tests. In addition to the impact sensitivity test (reported in the present study), large scale tests for the initiation characteristics include the Koenen test, which is used to identify if the test material can exhibit a thermal explosion when subjected to intense heat under confinement. The US gap test is commonly used for the purpose of determining if the potential explosive can undergo detonation when initiated by the detonation of a nearby explosive charge. Tests to determine the propagation characteristics of a potential explosive include detonation tube tests and the lead block test. The former is used to determine if the test material can support a propagating detonation once detonation is initiated. The later is used to determine the "explosive power" of the potential explosive. 


\section{REFERENCE LIST (general)}

ASTM E 680-79 Standard Test Method for Drop Weight Impact Sensitivity of Solid-Phase Hazardous Materials, ASTM Committee Meeting, 1984 revision.

Drop Weight Impact Sensitivity Tester

Guidelines for Chemical Reaction Hazard Evaluation, 6.3.Closed Tube Test, The Association of the British Pharmaceutical Industry,

The following is a list of useful references that contain detailed explanations of the detonation properties and the test methods employed for their study.

United Nations, Recommendations on the Transport of Dangerous Goods, Tests and Criteria. Ninth edition, 1995.

T.M. Groothuizen, J.W. Hartgerink and H.J. Pasman, $1^{\text {st }}$ Sympos. On Loss Prevention, Elsevier, Amsterdam 1974, p. 239.

J. Kohler and R. Meyer, Explosives, $4^{\text {th }}$ edition, VCH Publishers, Weinheim, 1993.

M.A. Cook, The science of high explosives, Reinhold, New York, 1958. 
喜 


\section{DROP WEIGHT \\ IMPACT SENSITIVITY TESTER}

\section{WARNING}

Extreme caution should be used when using this Impact Sensitivity Tester on propeliants, explosives, or other dangerous materials. 


\author{
SECTION 1
}

INTRODUCTION

WARNING

This Impact Tester was jesigned to evaluate the shock sensitivity of materials. Therefore, access to the machine and test materials must be limited. The operator should have proper safety equipment and fire control equipment (i.e. fire extinguishers) should be reajily available.

Safety Consulting Engineers, Inc. uses an impact tester Jesign similar to that of the Bureau of Mines for jetermining the impact sensitivity of hazarious liquils and solids. This system involves a 2 kilogram weight which is iropped from varying heights onto a steel cylinjer resting on the sample. The objective of this testing is to determine the impact (relative) sensitivity of materials. This information can then be used to jevelop a listing of hazarjous materials and their relative sensitivity to impact ranking. 


\section{SECTION 2}

\section{DESCRIPTION}

A Jiagram of the major parts of the Impact Tester is shown in Figure 1.

The base is constructed of heavy gauge steel to provide a rigij framework. It is recommenjed that the jrop tester be mounted on a 30-inch concrete base, by bolts, through the four (4) Jrop test base mounting holes.

In the center, of the base is the anvil head and base. To insure proper operation, these parts should be screwej jown tightly. The jrop weight guijes must be in the exact vertical plare. The samples are placed in the open sample holjer on the center of the anvil heas.

The intermediate weight is the cylinjer which is guided through the hole in the intermejiate base. It is placed carefully onto the sample juring testing with the large flat end up and the small end jown. Before testing begins and periojically thereafter, the small end must be kept tightened to insure proper operation.

The three jrop weight guijes are jesignej to support the pulley stanj and to act as guijes for, the irop weight. One of the Jrop weight guijes has been equipped with a meter scale for recording the height from which the weight is iropped. This scale reajs height from the top of the intermejiate weight.

The jrop weight is a two kilogram steel cylinjer with a tapered end. The tapered end points jown towards the inter- 
mejiate weight.

CAUIION: Do not place hands beneath jrop weight when it has been raised off of the intermediate weight, unless it has been securely blocked up by a metal plate. The height ajjusting cable is a lightweight nylon rope which is attached to the eilectromagnet. DANGER: DO NOT LET GO OF THE CABLE WHEN THE DROP WEIGHT IS ATTACHED AS DAMAGE TO THE ELECTROMAGNET WILL RESULT.

The electromagnet has been very carefully jesignejand ajjustej to your unit. Do not remove the tape from the bottom of the electromagnet or it may not release from the jrop weight jue to residual magrietic energy.

\section{$\therefore \quad$ HARNING}

When setting up the Impact Tester for operation after shipping, tighten all bolts to insure proper ani safe operation of this tester. 


\section{SECTION 3}

\section{OPERATING PROCEDURE}

\section{A. INITIAL_SETUP}

Check all bolts anj fittings. The taster was shippej with the bolts tightered. However, a check should be maje to insure that they are still tight.

WARNING: No test material should be present until all checks have been maje and the tester. is functional.

Make certain that the tester is mountej on a level surface tefore bolting it Jown. Also, make certain that the Irop weight Euijes are in the vertical plane. He recomend that a 30 -inch concrete base be usej (see Figure 2 ).

Arter the base has been mounted, insert the intermediate height into the irtermediate base. Make certain that it slijes smoothly and easily. Nake sure that the impact surface of the intermejiate weight is making a good contact with the oper sample roljer. An easy methoj for the jetermination is given in Reference 3 .

Remove the pulley stand base anj insert the jrop weight into the Irop weight guises. Carefully lower the Irop weight onto the intermeliate weight. Reattach the pulley stand base to the tops of the irop weight guides. Make certain that the bolts are tightenej securely.

Thread the height-ajjusting cable through the pulley and attach it to the electromagnet.

Attach the electromagnet to the drop weight and activate it. 
Lift the drop weight and make certain that it slides freely and easily. Deactivate the electromagnet and make certain that it releases smoothly.

\title{
WARNING
}

You are jropping 11 pounds of steel. Do not put hanjs or objects, other than the intermejiate weight, unjer the jrop weight.

B. DEIERMINATION_OF_INPACI SENSITIVITY

\section{WAFFING}

\begin{abstract}
Hazarjous materials are being tested. Control of the test area anj test materials is absolutely necessary. Persons operating or observing the tester should have safety glasses and ear protectors.
\end{abstract}

The foilowing is the recomimented procejurefor conjucting

jrop tests:

1. The jrop weight should be lifted via the electromagnet anj blockej up. We recominend an "L" shaped piece of mietai 6" $x$ 8" with a $3 / 4 "$ "L" benj at the top to be usej. ( $k^{2} r_{b} \in r_{1}$ in place, it $k i l l$ be an invertej "L").

2. The intermediate weight should be removed.

3. Forty (40) $\mathrm{mm}^{3}$. of test sample should be placej onto the center of the open sample holjer.

4. The intermediate weight should be replacel carefully. Remember that the sample you are testing is impact sensitive.

5. The jrop weight should be raised slightly and the support removej.

6. Step back to a. safe jistance.

7. Raise the jrop weight to the test height. 
8. Release the drop weight via the electromagnet.

DANGER: DO NOT RELEASE THE HEIGHT ADJUSTING CABLE AS THIS WILL DAMAGE THE ELECTROMAGNET.

If an audible report (other than from the weight jropping), a flash, smoke, the ofor of burning or a jiscoloration of the sarple jue to jeccrposition is observej, the test is a "Eo". Otherwise it is a "no Eo".

To prepare for the next test, the following is the reconminj $\operatorname{loj}$ procejure:

1. Raise the irop weight $v i a$ the electromagnet anj block it up.

2. Remove the intermejiète veieht ani clear it vith a brush or dry cloth.

3. The oper sample holjer shouij be cleanel with a blower. - brush or iry cloth:

CAUTION: Do not allon siErificart amounts of reactel or unreacted mieterial to collest around the base of the tester. Fiemember, you are workirig with flamable r:azärjous r:aterial.

Steps 3 through 8 may then be repeated for the next test height.

A Bruceton up-anj-jown. test procejure is strongly recommenjej. In a Bruceton test series, a number of equally spacej intervals are usej. A test that results in a "go" injicates that the next lower interval should be used. We suggest using a log increment, as the use of log increments generally give a more accurate determination of the 50 percent point. A suggested log scale is given in Table 1. For more jetailed information, see any of the references listed. 
TAHL: 1

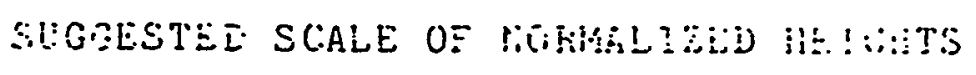
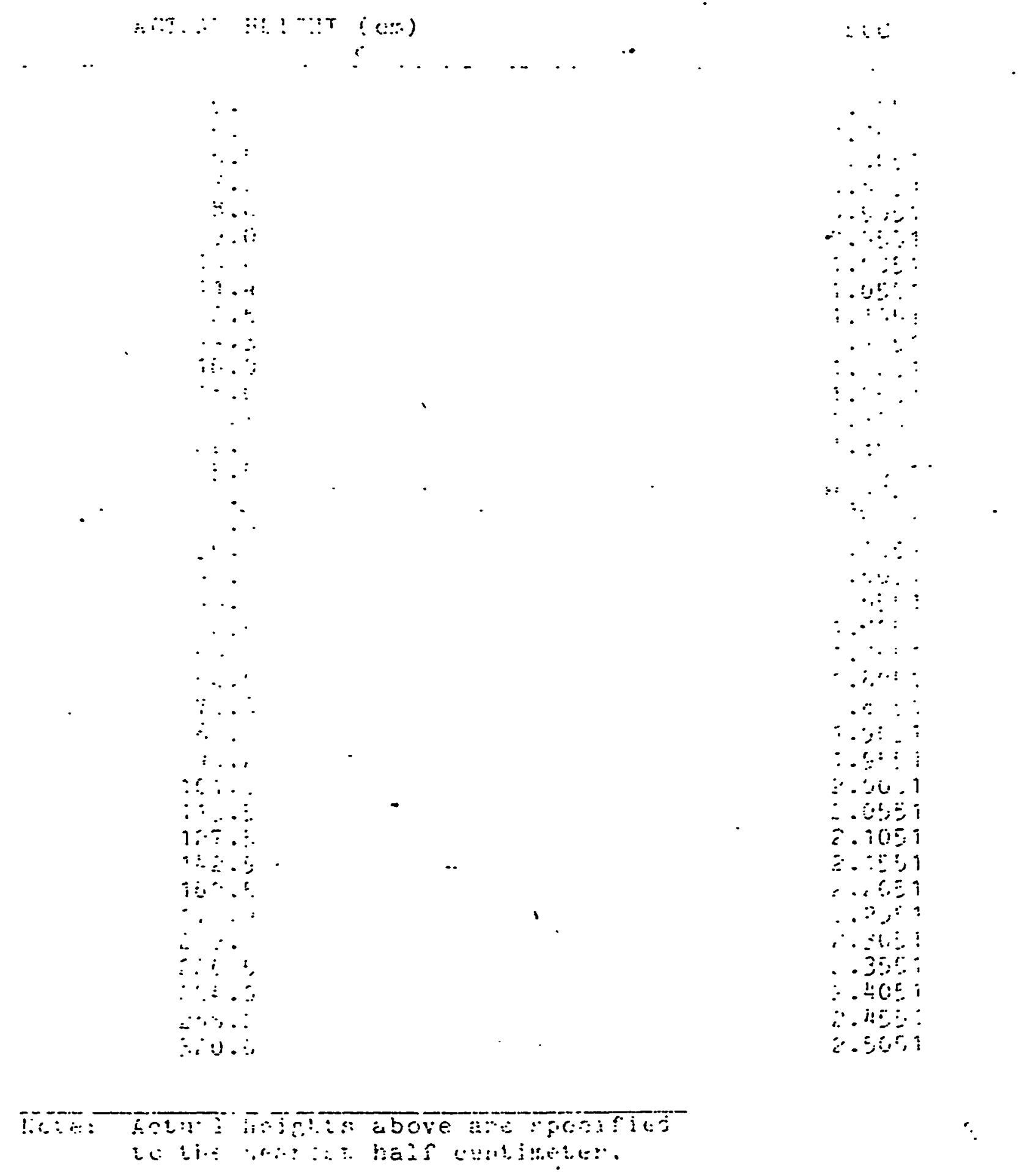
The Bruceton Series provijes a means of jetermining the 50 percent point of the test material. This will allow a relative list of sensitivities to be jeveloped. 
CALCIULTIONS OF $50 \%$ POINT

Organization of Per!juent Quallities for Calculations

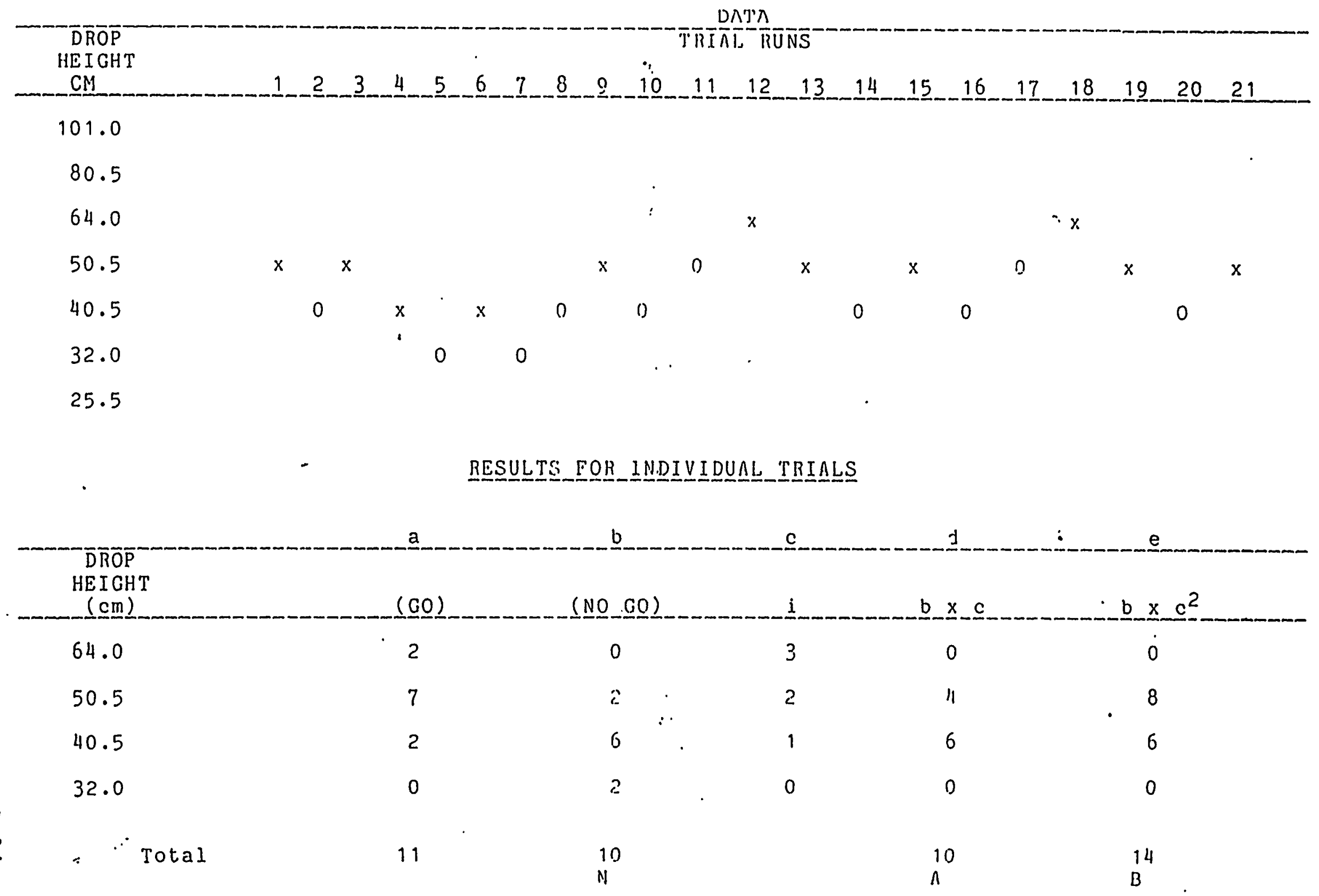




\section{CALCULATIONS OF 50\% POINT (continue.}

$$
\begin{aligned}
& (A+1) \quad \text { Mea } \\
& M=c+1\left(\frac{A}{N} \pm \frac{1}{2}\right)
\end{aligned}
$$

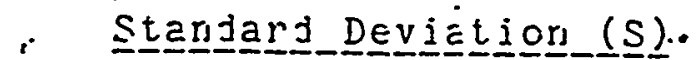

$$
\begin{aligned}
& S=1 . \overline{5} 2\left[\left(\underline{l}_{\bar{E}} \bar{E} E^{E}\right)+0.029\right] \\
& c=\text { loE value of tr.e lobest lest leve? on which the } \\
& \text { frequent evenl occlirrej; for Exämple } 10 \mathrm{E} 32 \text {, } \\
& J=\text { differerce betkeen the lof increnents, } \\
& n=\begin{array}{c}
\text { number of "go" or "no so" at a particular height } \\
\text { level }
\end{array} \\
& \| \text { = total number of " } 50 " \text { or "no } 50 " \text { in the complete } \\
& \text { lip-anj-jown testen } \\
& i=\text { mituiplier inzex, far Example; } 1 \text { - ofor } c \text {, } \\
& i=i \text { for ct } j \text {, } \\
& \text { - } \quad \dot{E}=\Sigma \vdots \\
& E=\sum i \hat{z}_{r}
\end{aligned}
$$

:Oote: lits a calculatine the fiear, use the "+" sign in the Equation if lisinE "no EO" iate. Use the "-" sien if usir:e the "go" Jeta. 
- ENERGY/SURFACE AREA CALCULATIONS.

2kㅡㅁ Drop Weight

Impact Energy (Joules) $=$ (Drop Height in Meters) $\times 19.6$

Energy/Surface Area (Joules/meter ${ }^{2}$ ) $=$ Impact $\frac{\text { Energy }}{0.00013}$

1 
REFERENCESS

1. Dixon, W. J., Massey, F. J., Jr., Introjuction to Staticical Analysis, MeGraw Hili, Inc., 1957 , pp. $319-327$.

2. Statistical Research Group, Princeton University, Statisistical

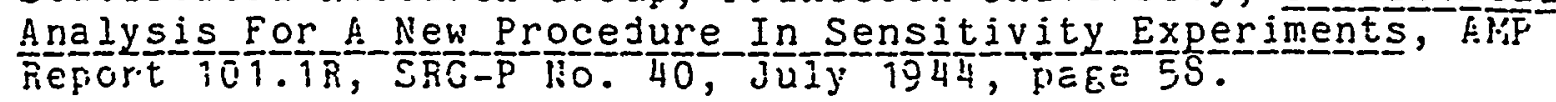

3. ASTl: Cornittee nepcrt, Stanjarj iest For Dropkeight Sensitivity_or_SolidPhépe.

$14-14$ 
D:lapplSludgelvendorlVendorReconcile.doc

\section{APPENDIX 2}

\section{See Body of Main Report}

Appendix C "Mercury Fulminate Preparation Procedure"

Appendix F "ASTM E680 Impact Hammer Tester" 
意

$\omega$

: 


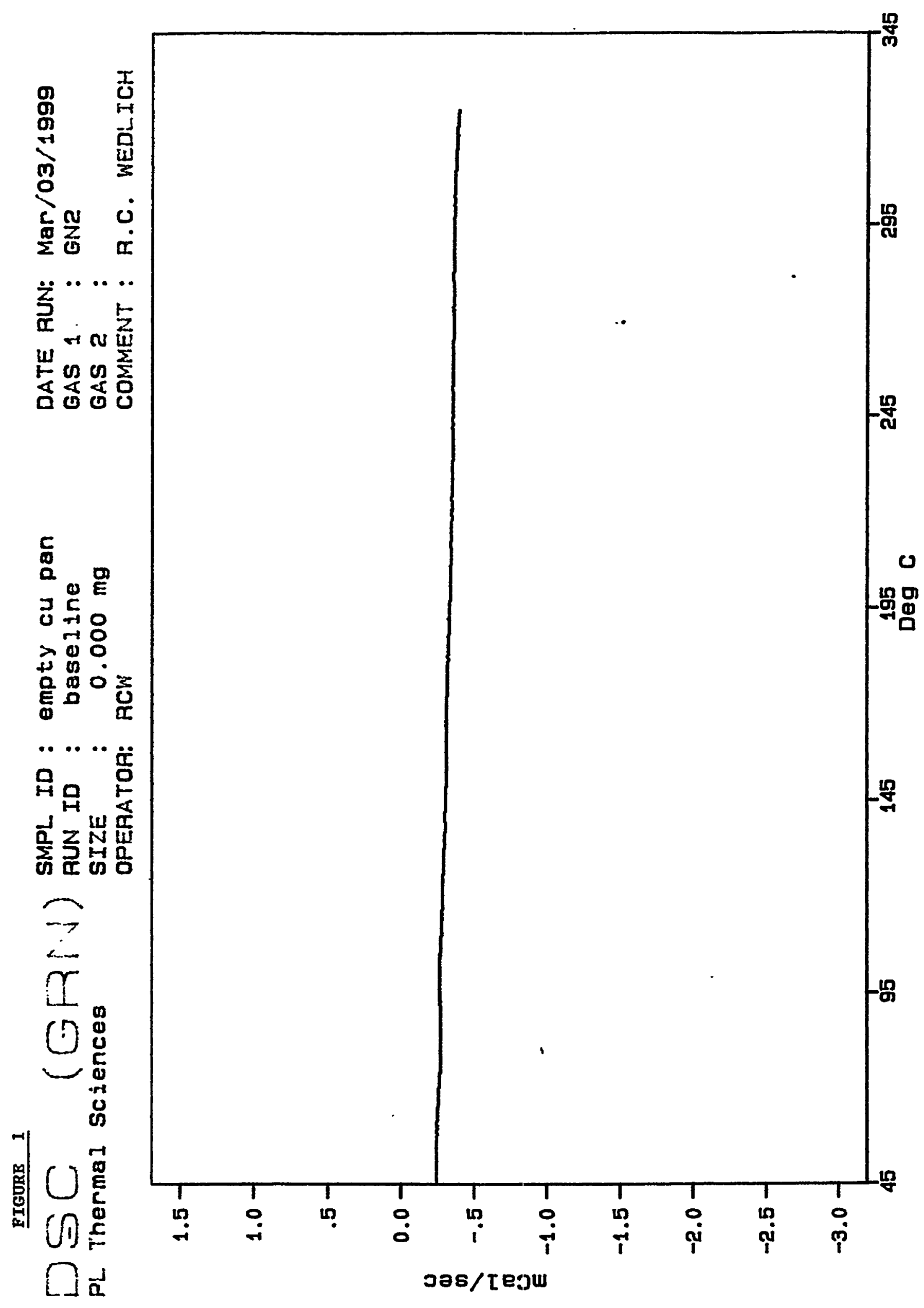




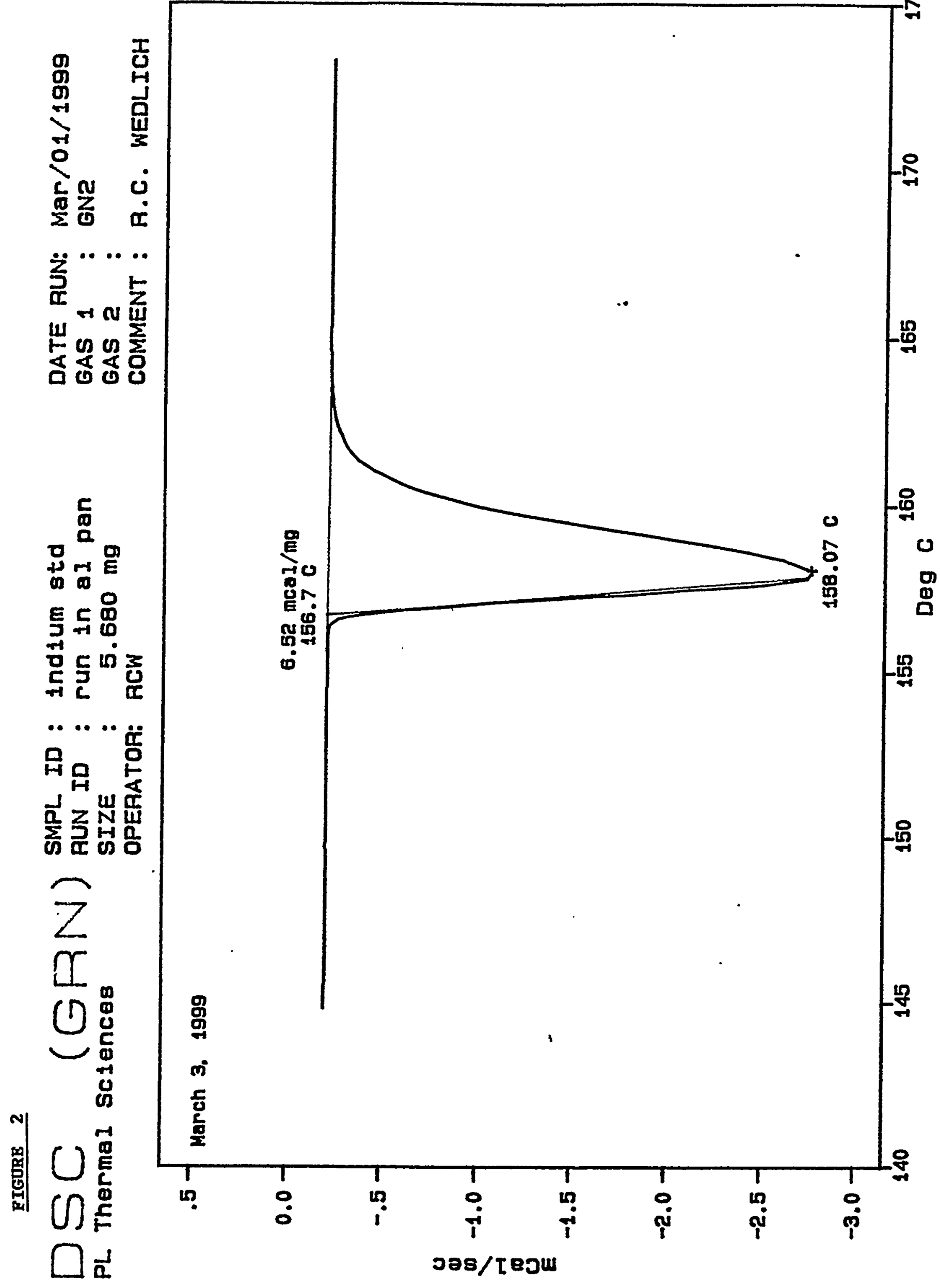




\section{Indium Melting Point Standard}

Differential Temperature

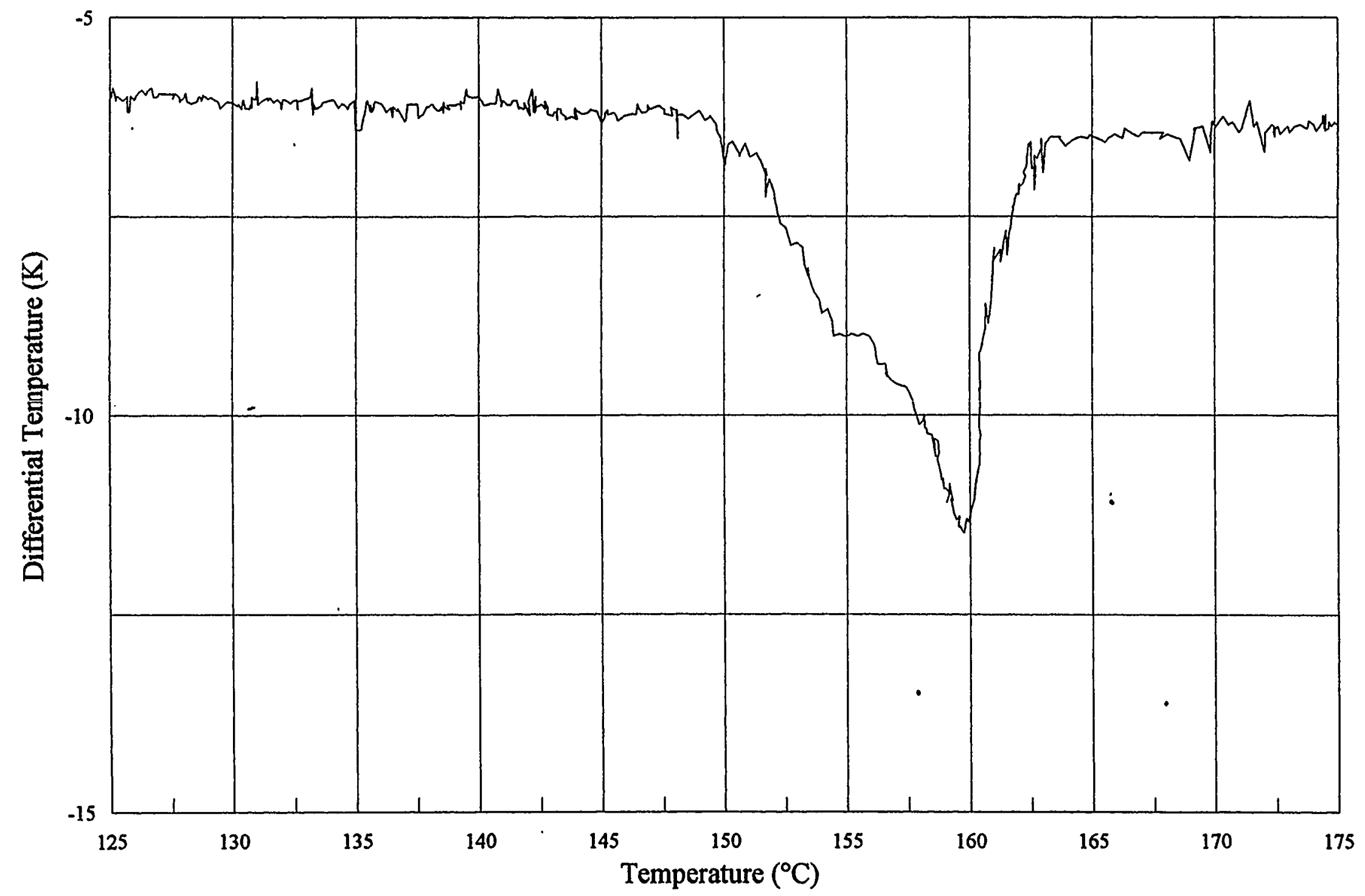

CINDla/b.TXT 


\section{APPENDIX 4}


FIGURE 3

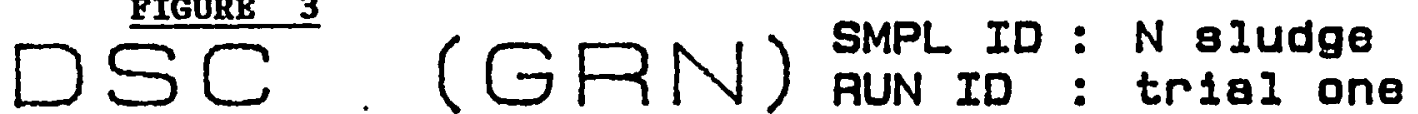

DATE RUN: Feb/27/1999

PL Thermal Sciences

SIZE : $9.300 \mathrm{mg}$

GAS 1: GN2

OPERATOA: RCW

GAS

COMMENT : A.C. WEDLICH

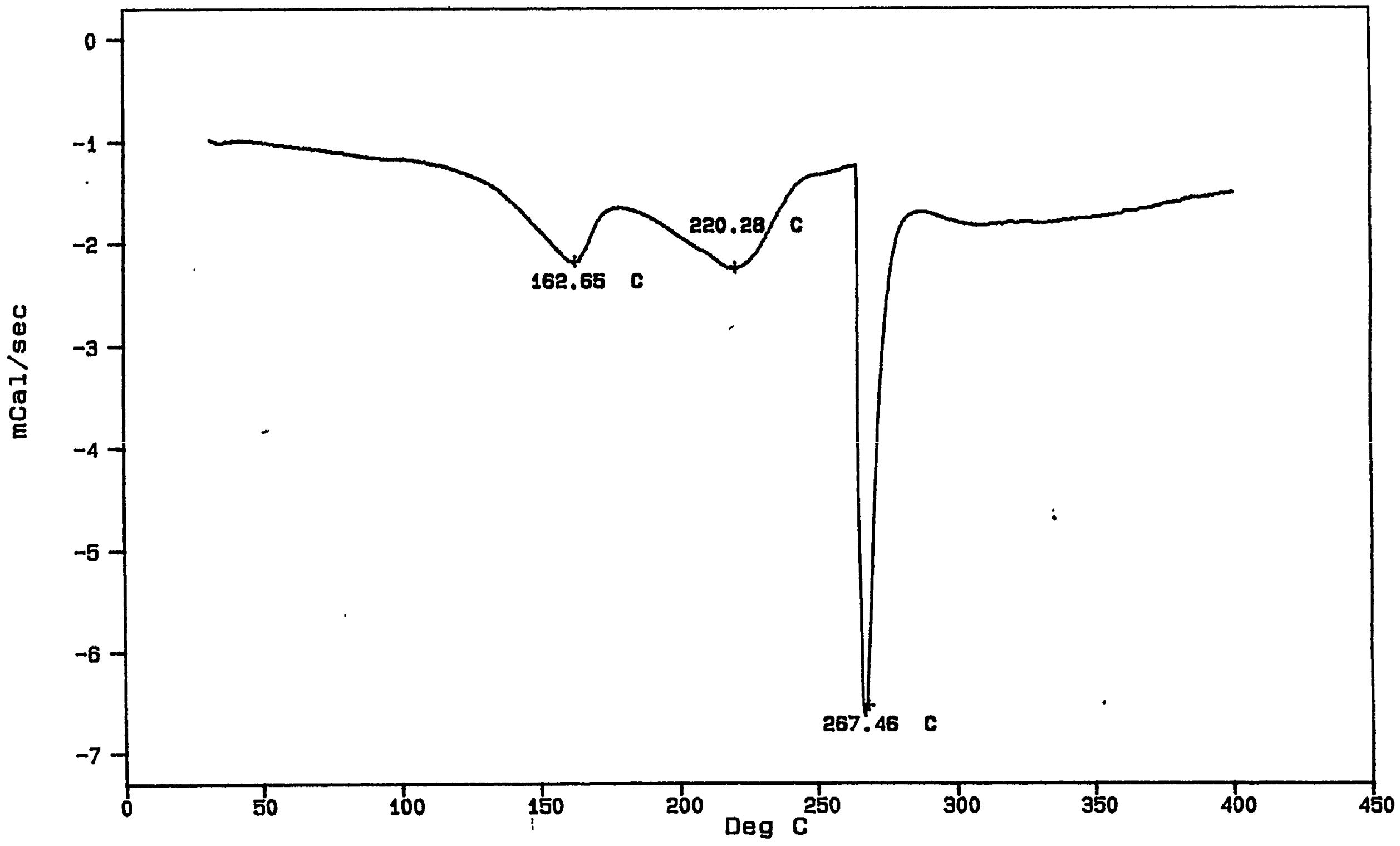

VERSION: VA. 30 
FIGURE 4

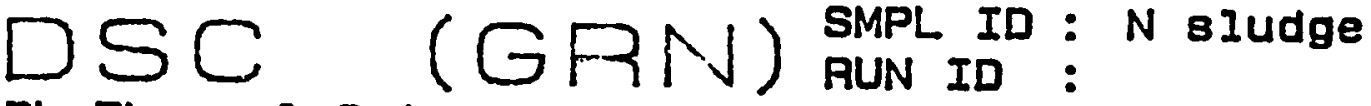

PL Thermal Sciences
SIZE : OPERATOR: RCW
DATE RUN: Feb/28/1999

GAS 1: GN2

GAS 2

COMMENT : R.C. WEDLICH

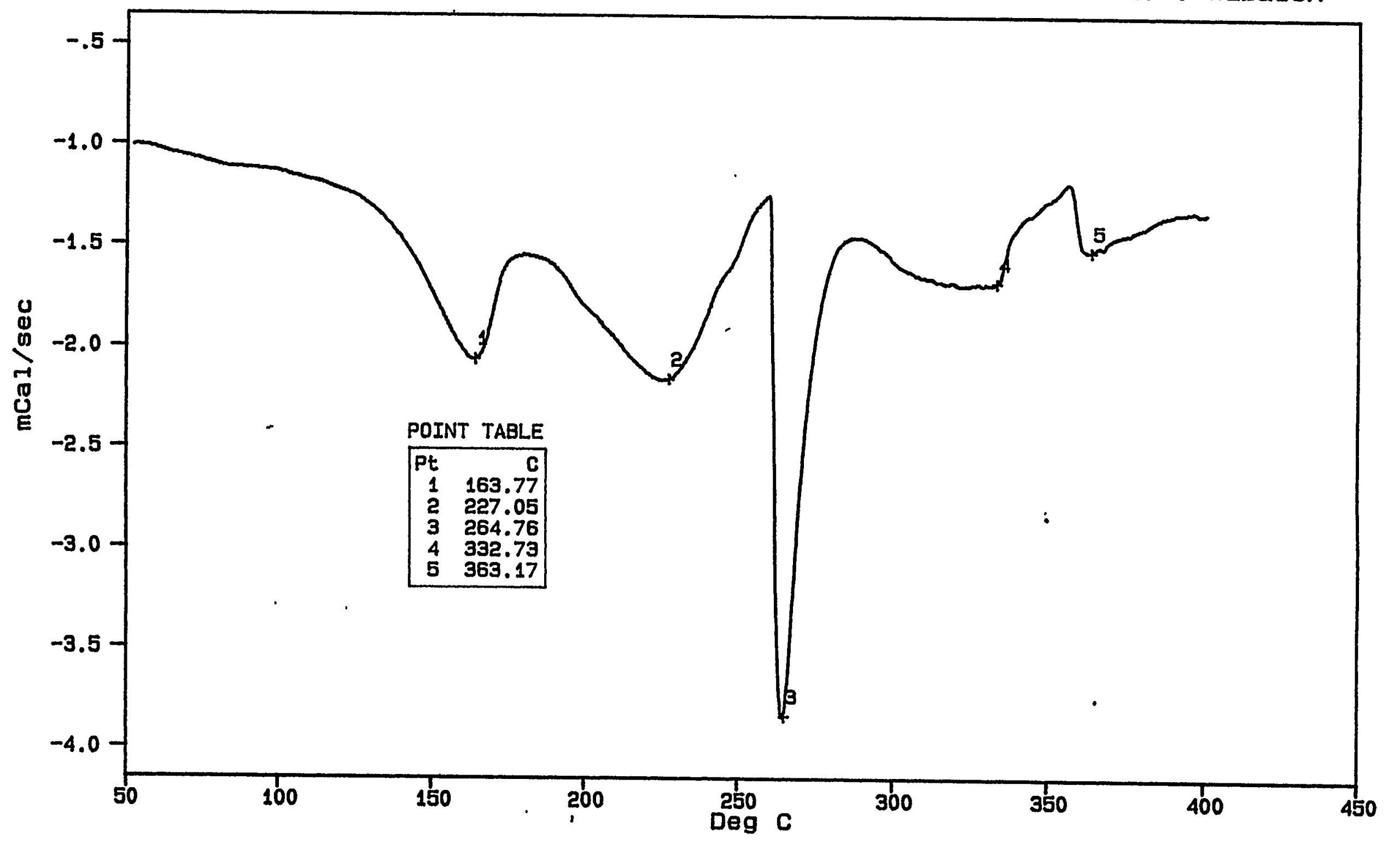

VERSTON: VA.30 
FIGURE 5

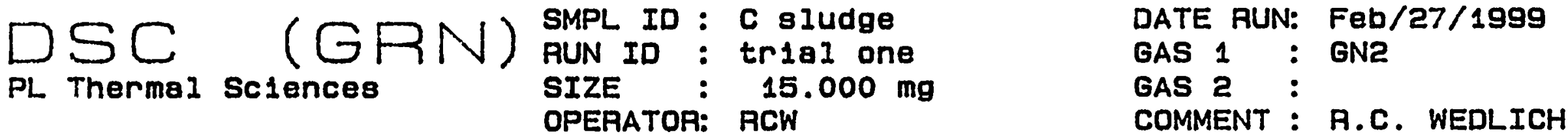

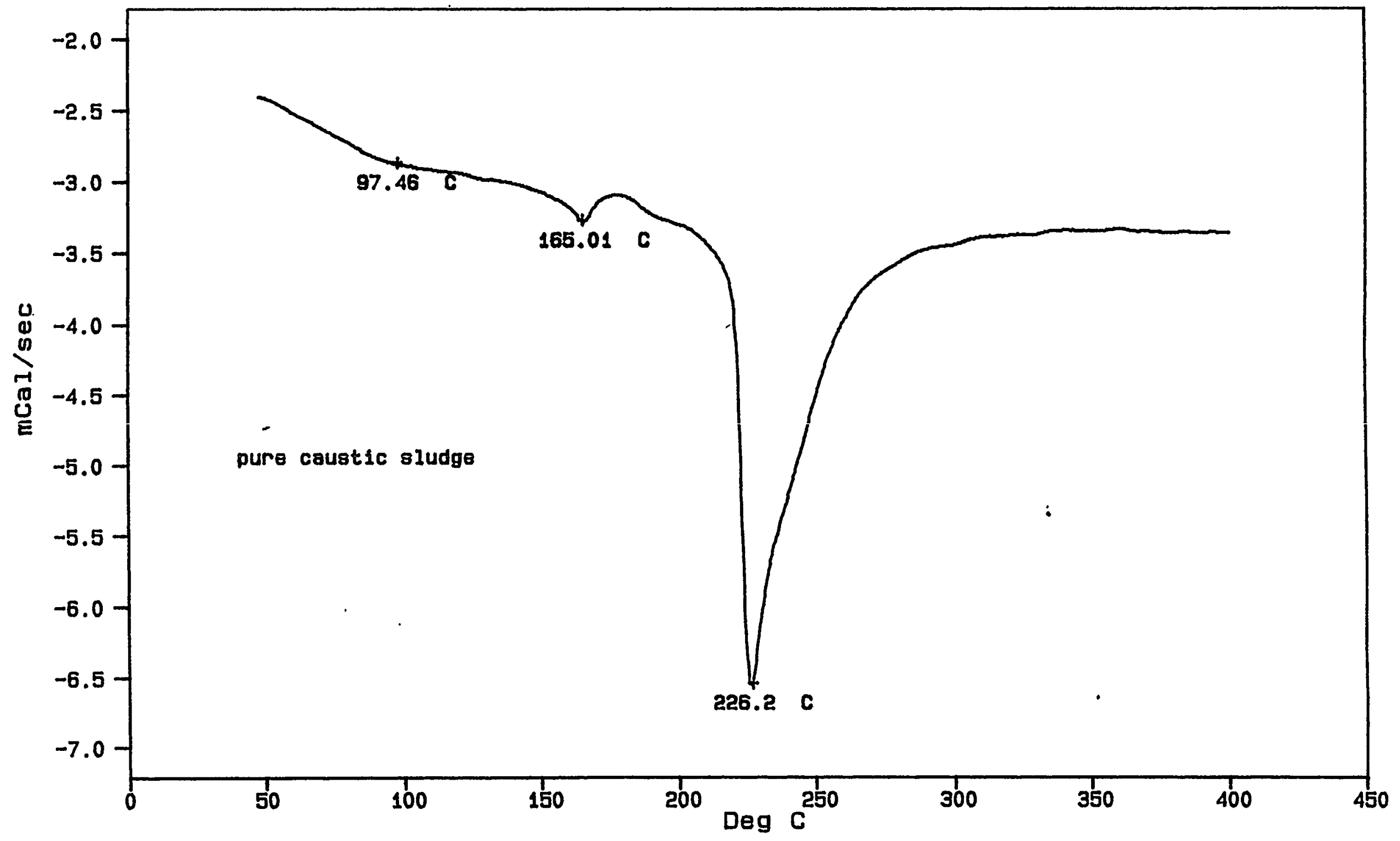

VEASION: VA. 30 


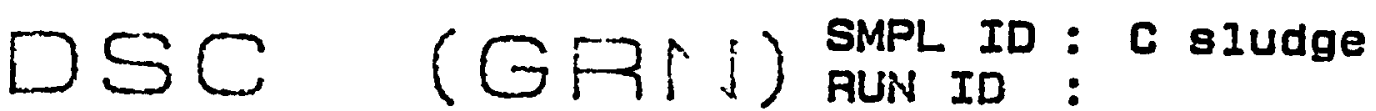

PL Thermal Sciences
SIZE : $18.240 \mathrm{mg}$ OPERATOR: RCW
DATE RUN: Feb/28/1999

GAS 1: GNa

GAS 2

COMMENT : R.C. WEDLICH

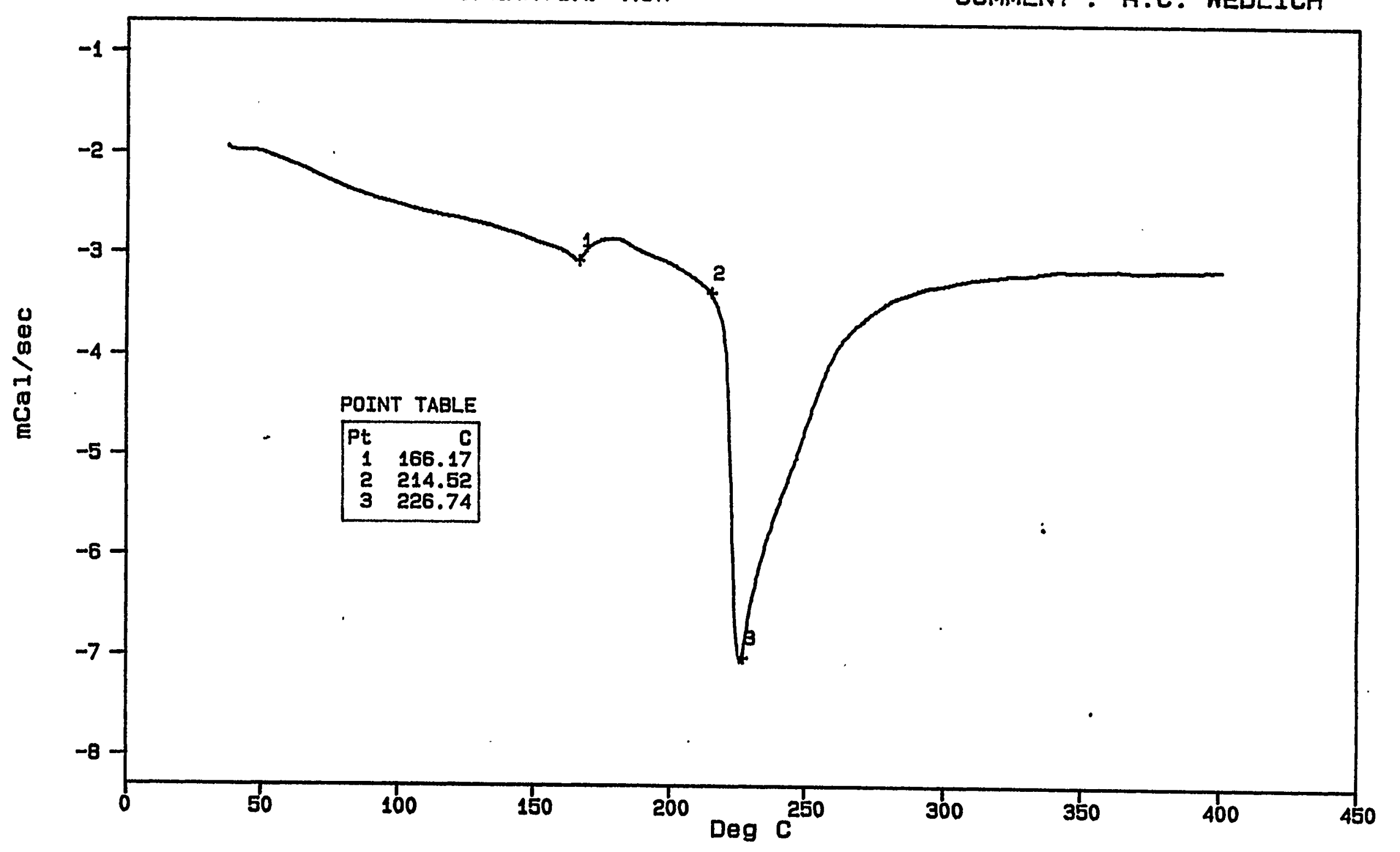

VERSION: VA. 30 


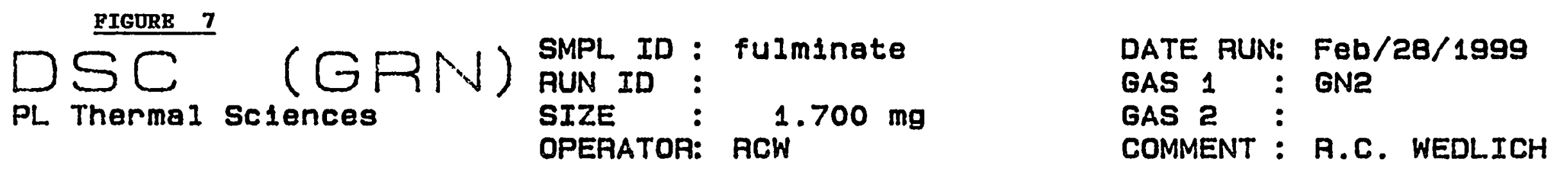

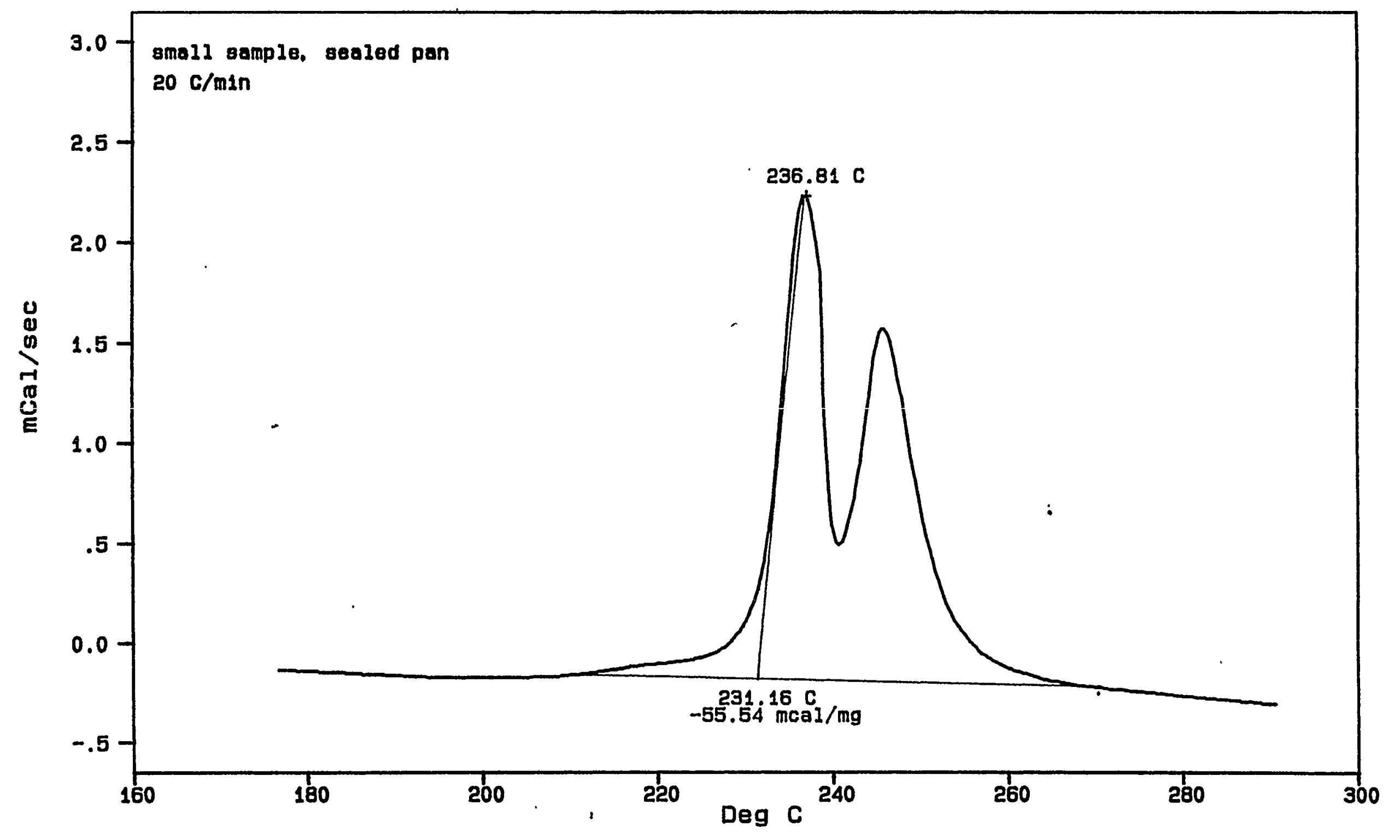




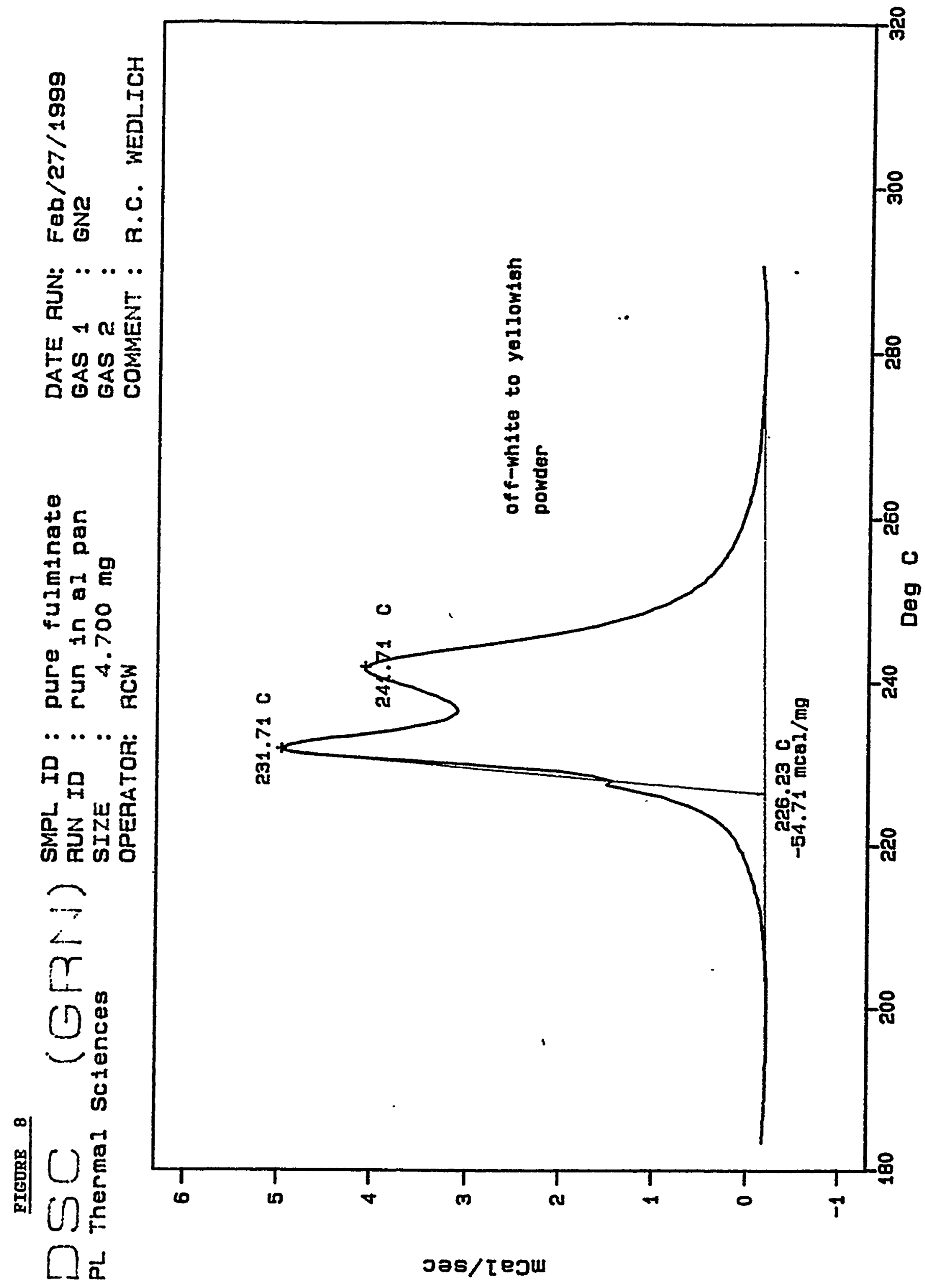

0
1
5
5
5
5
5 
EIGURE 9

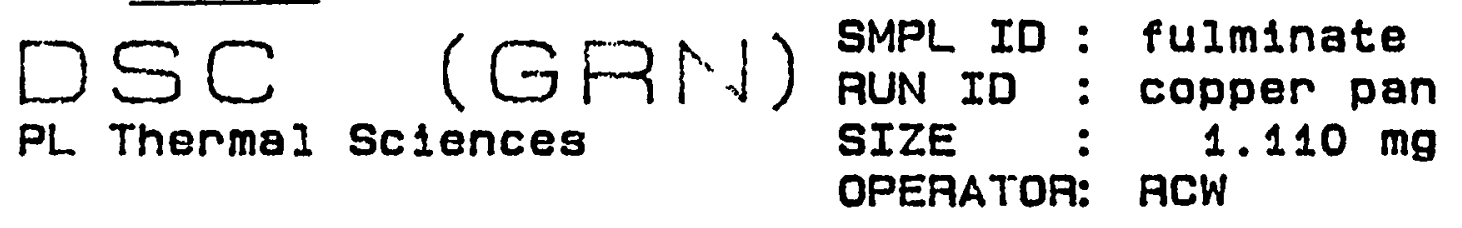

DATE RUN: Mar/03/1999

GAS 1 : GN2

GAS $2:$ :OMMENT: R.C. WEDLICH

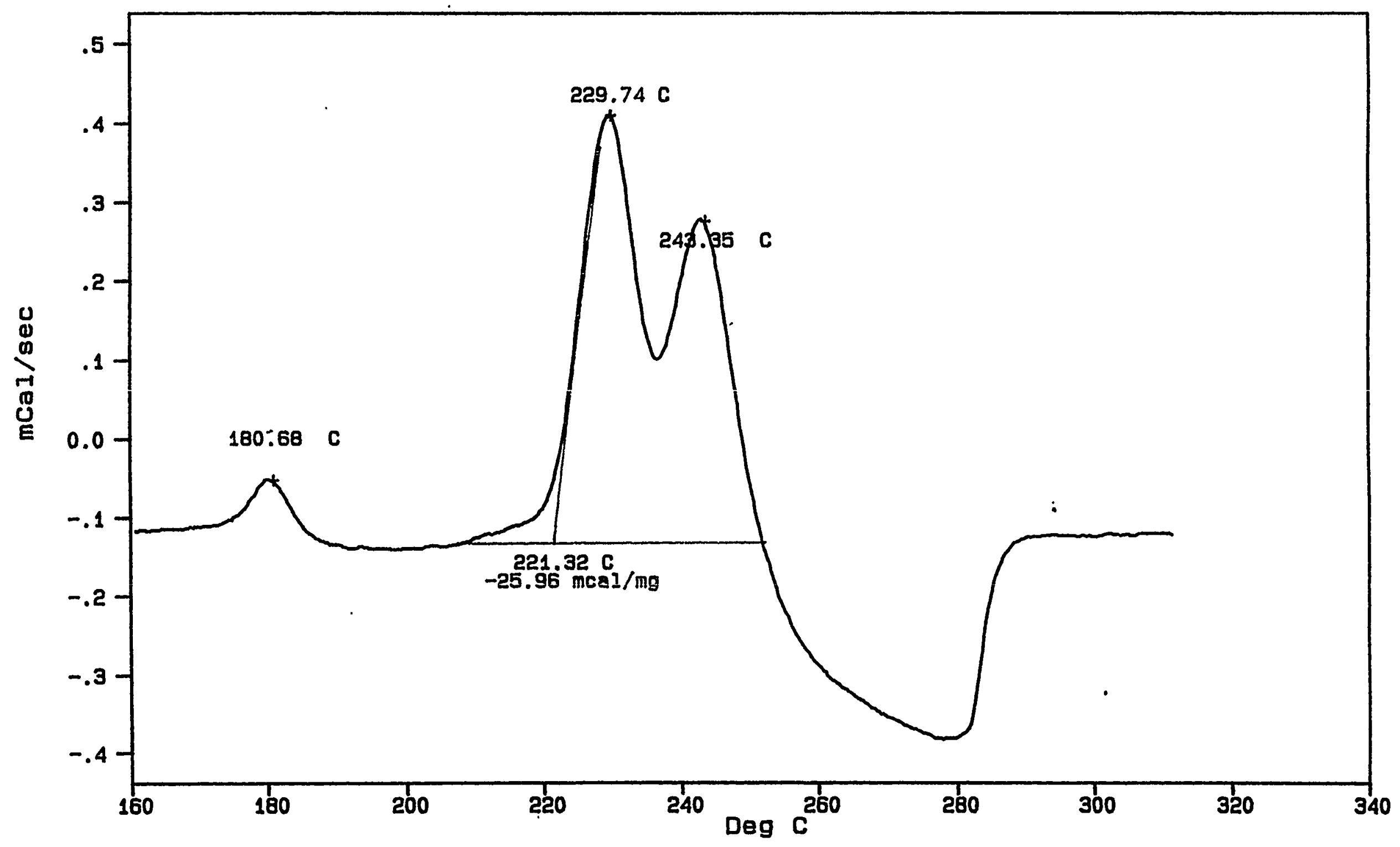


IGURB 10

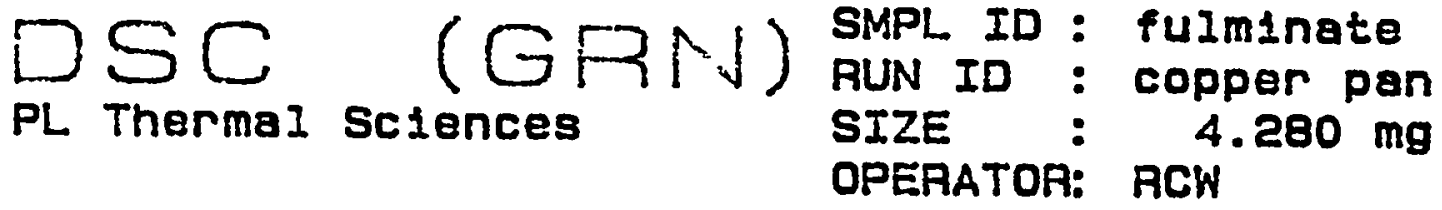

DATE RUN: Mar/03/1999 GAS 1: GN2

GAS 2

COMMENT : R.C. WEDLICH

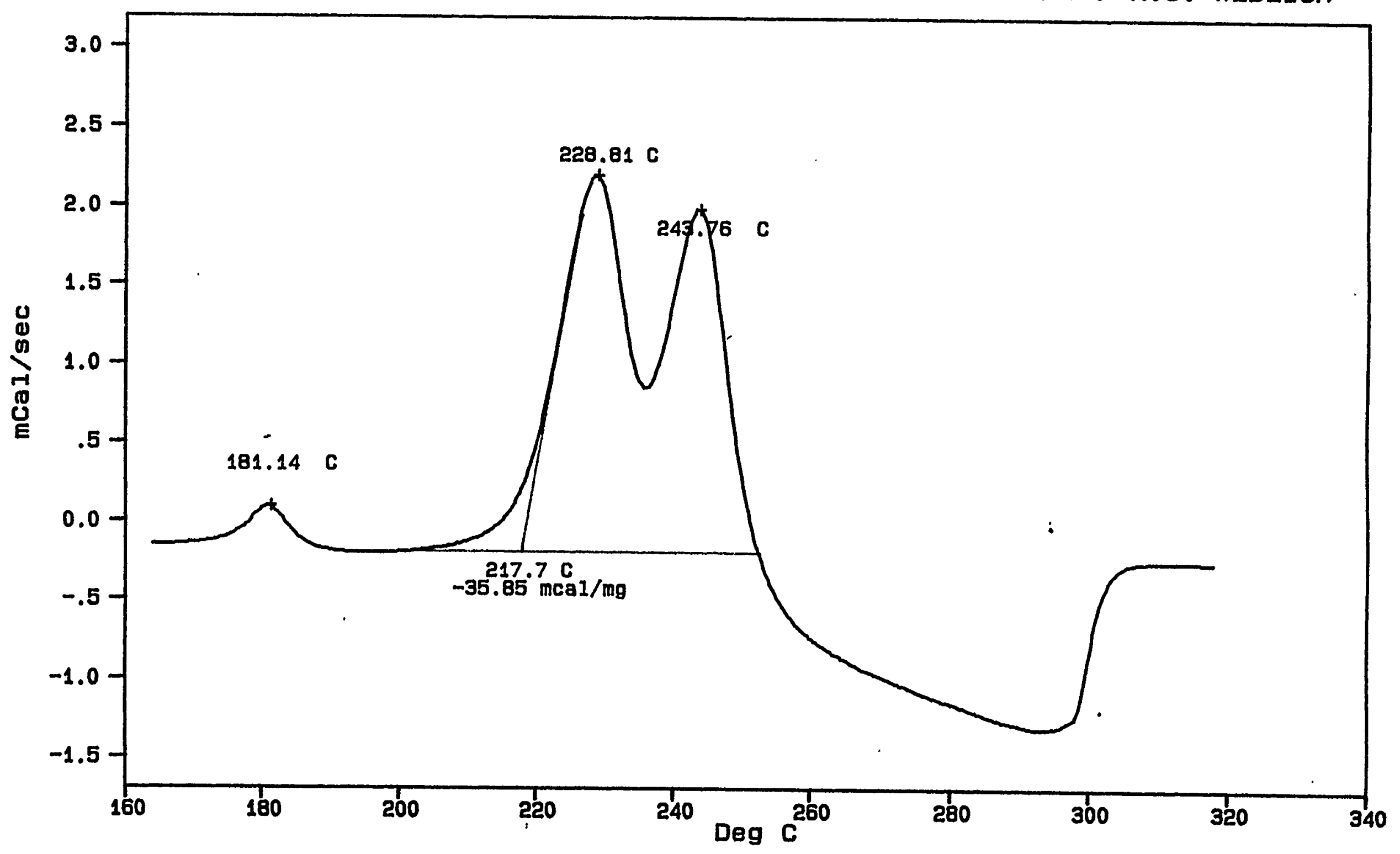

VEASION: V4.30 
$\longrightarrow \longrightarrow$

PL Thermal Sciences
(QP SMPL ID : white fuIminate

RUN ID : crimped al pan SIZE OPERATOR: ACW
DATE RUN: Mar/03/1999

GAS 1 : GN2

GAS 2

COMMENT : A.C. WEDLICH

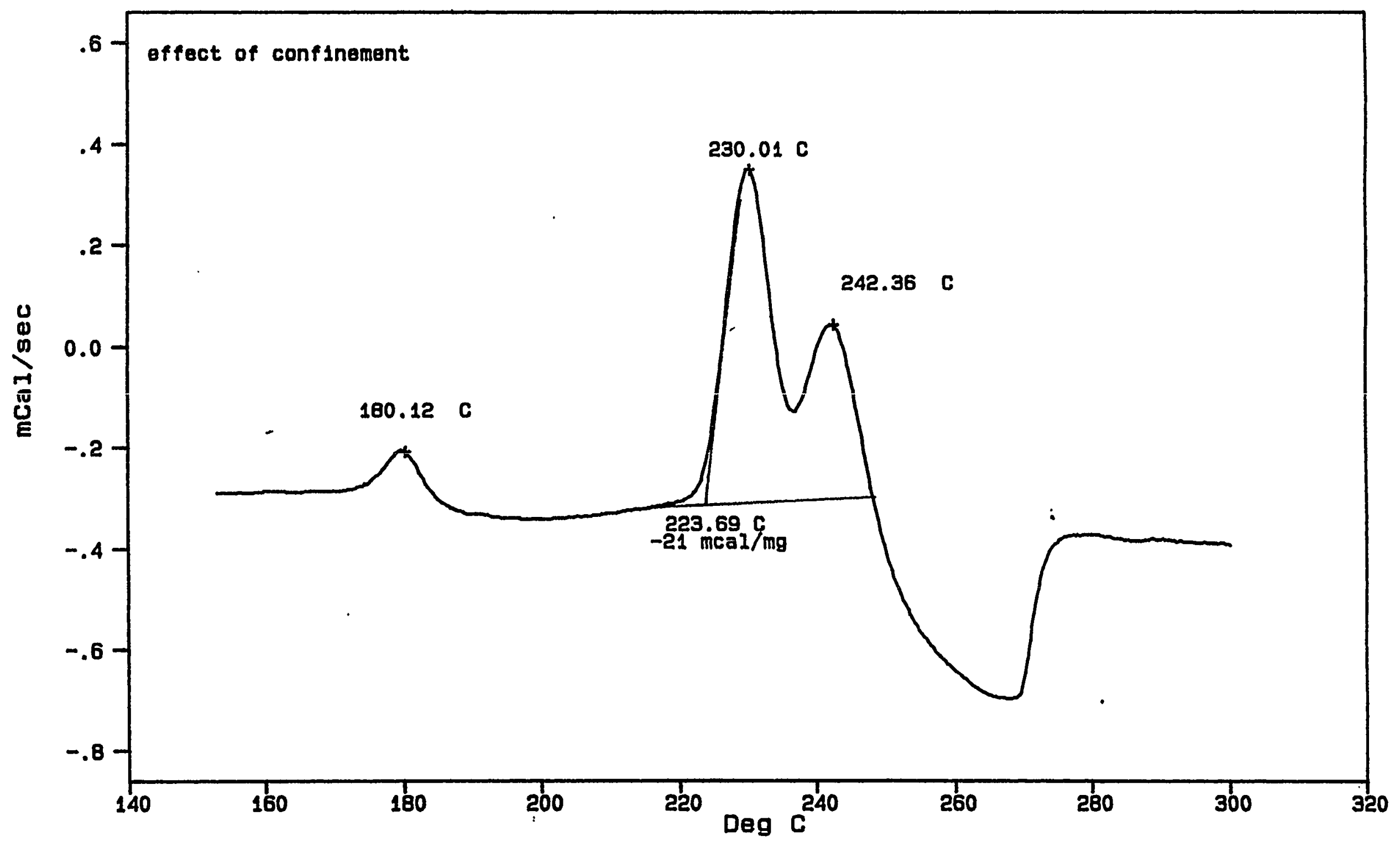



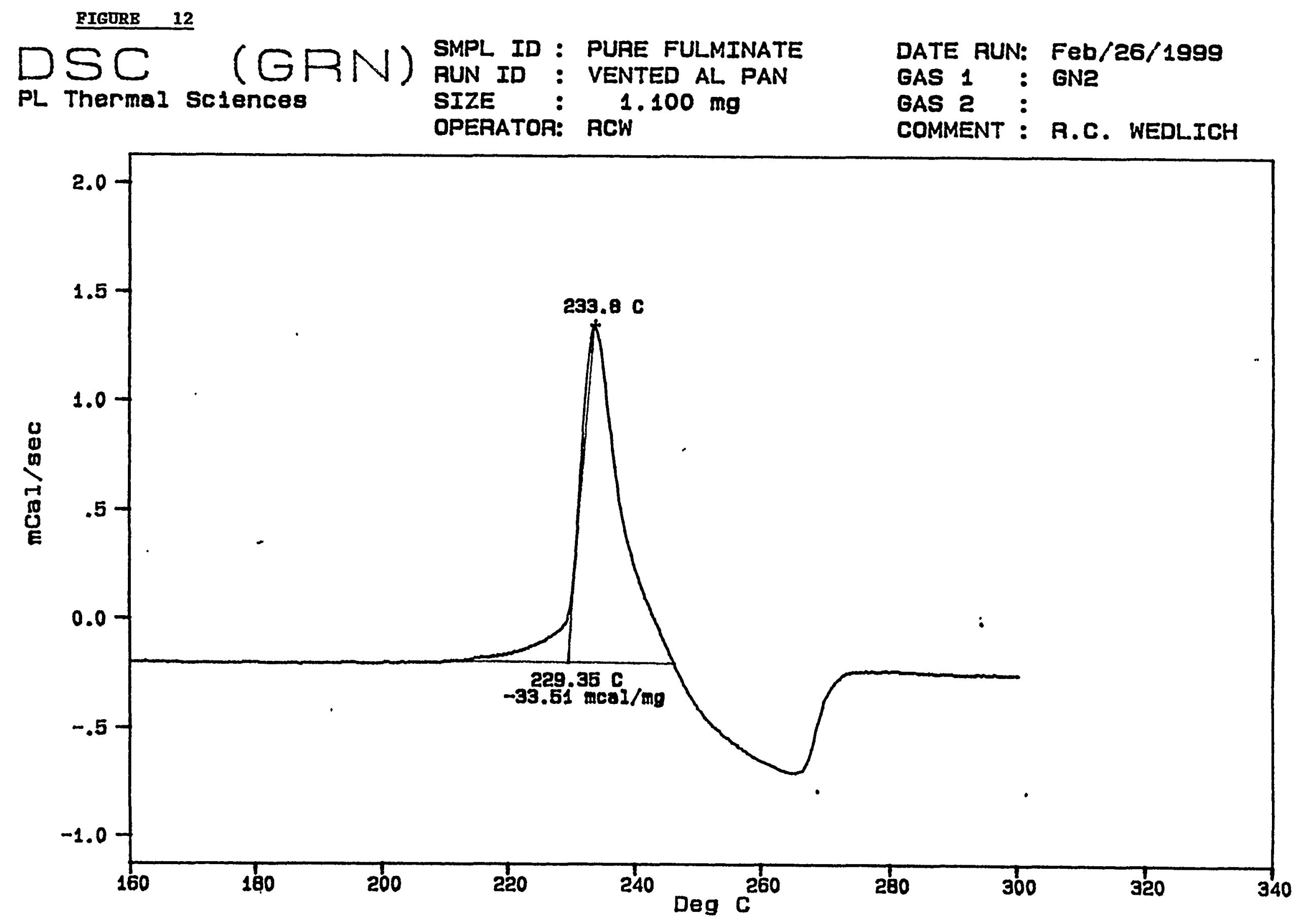


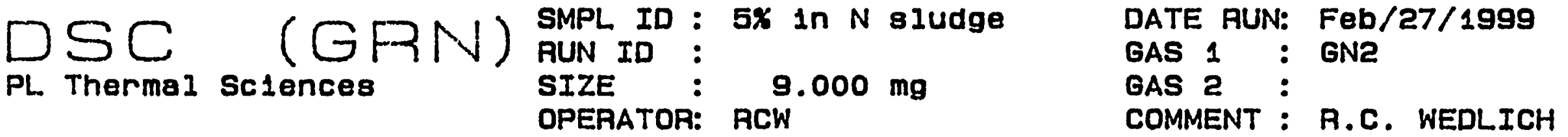

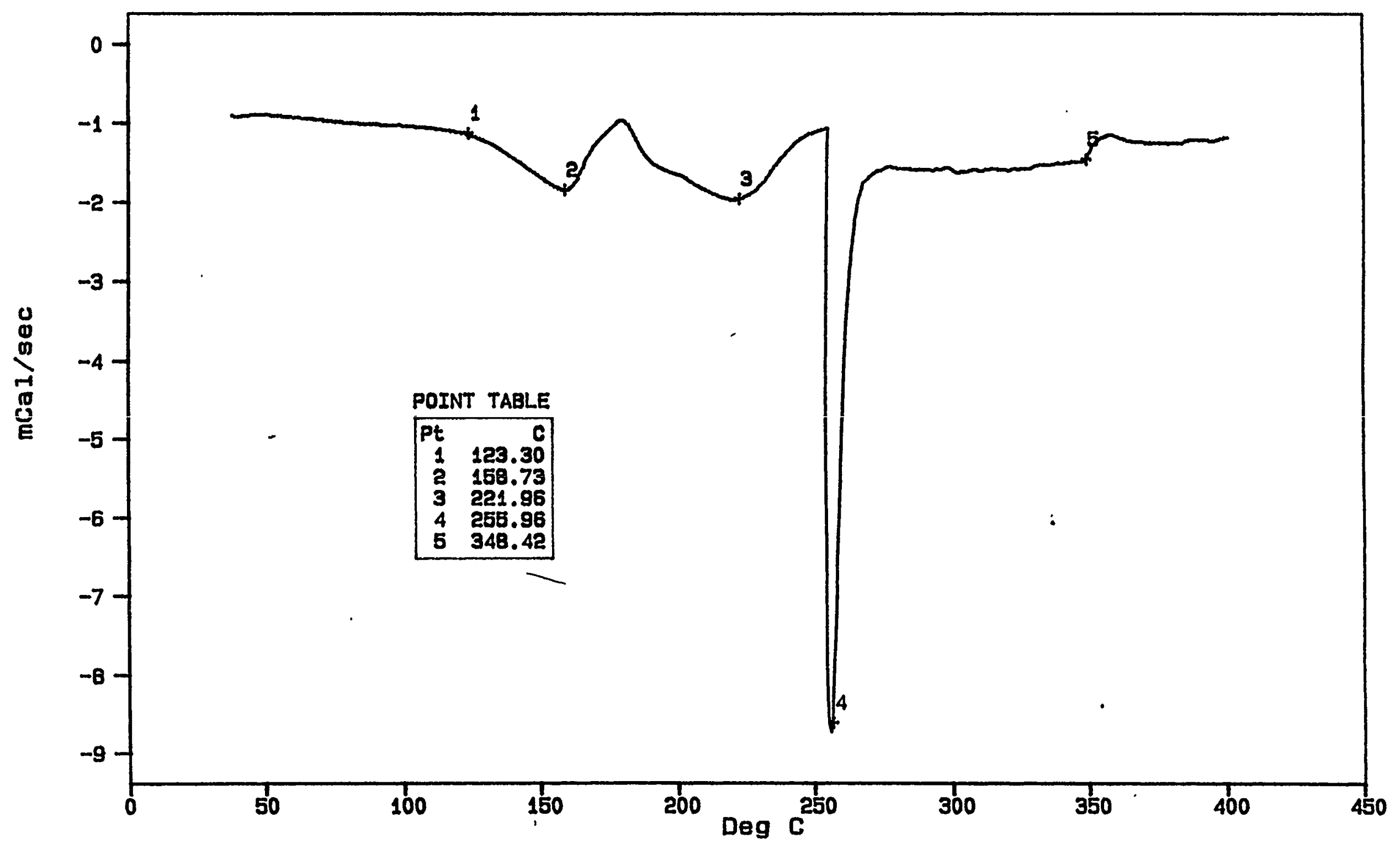


$\square \sum^{\text {EIGURE } 14}$

( $\neg N)$ SMPL ID: $10 \%$ in $N$ sludge

SMPL ID: $N$ siudge

COMMENT : R.C. WEDLICH PL Thermal Scjences

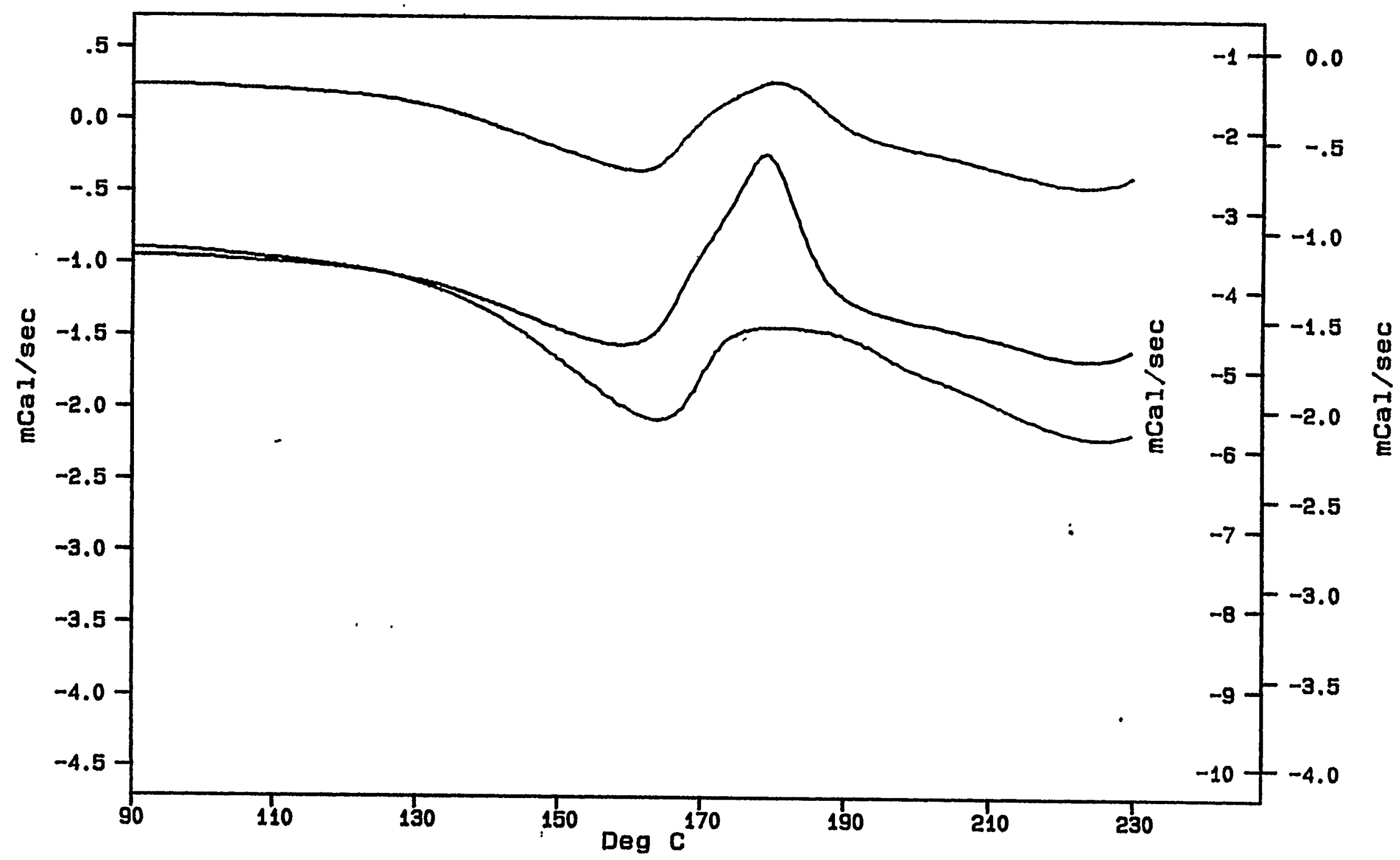




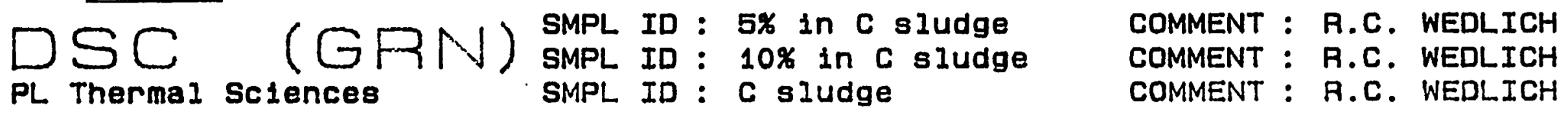

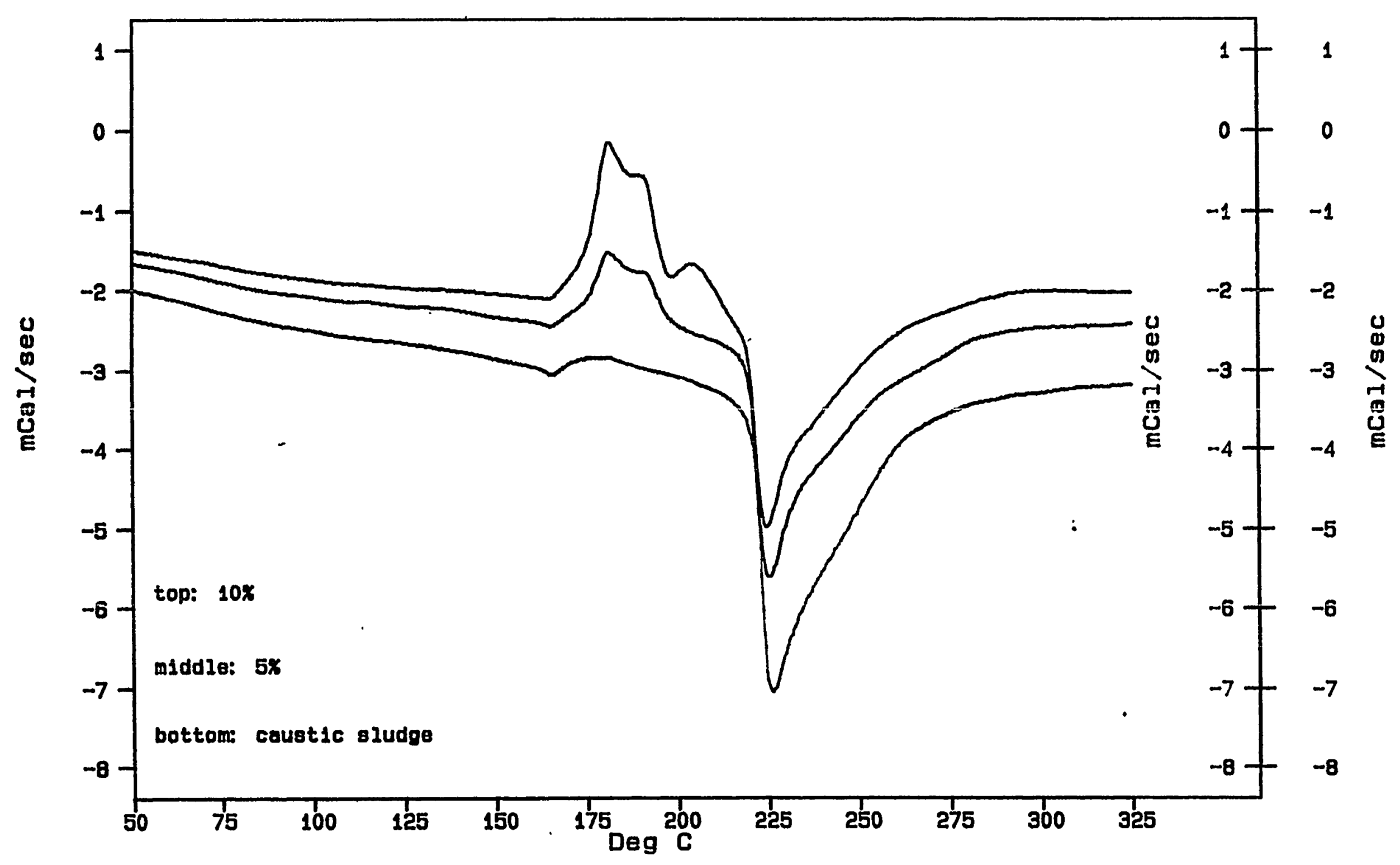


FIGURE 16

$D S C \quad(G R \hat{\jmath} \cdot j)$ SMPL ID : $5 x$ in C siudge

PL Thermal sciences

SIZE : $14.780 \mathrm{mg}$ OPERATOR: RCW

DATE RUN: Feb/28/1999

GAS 1 : GN2

GAS 2

COMMENT : R.C. WEDLICH

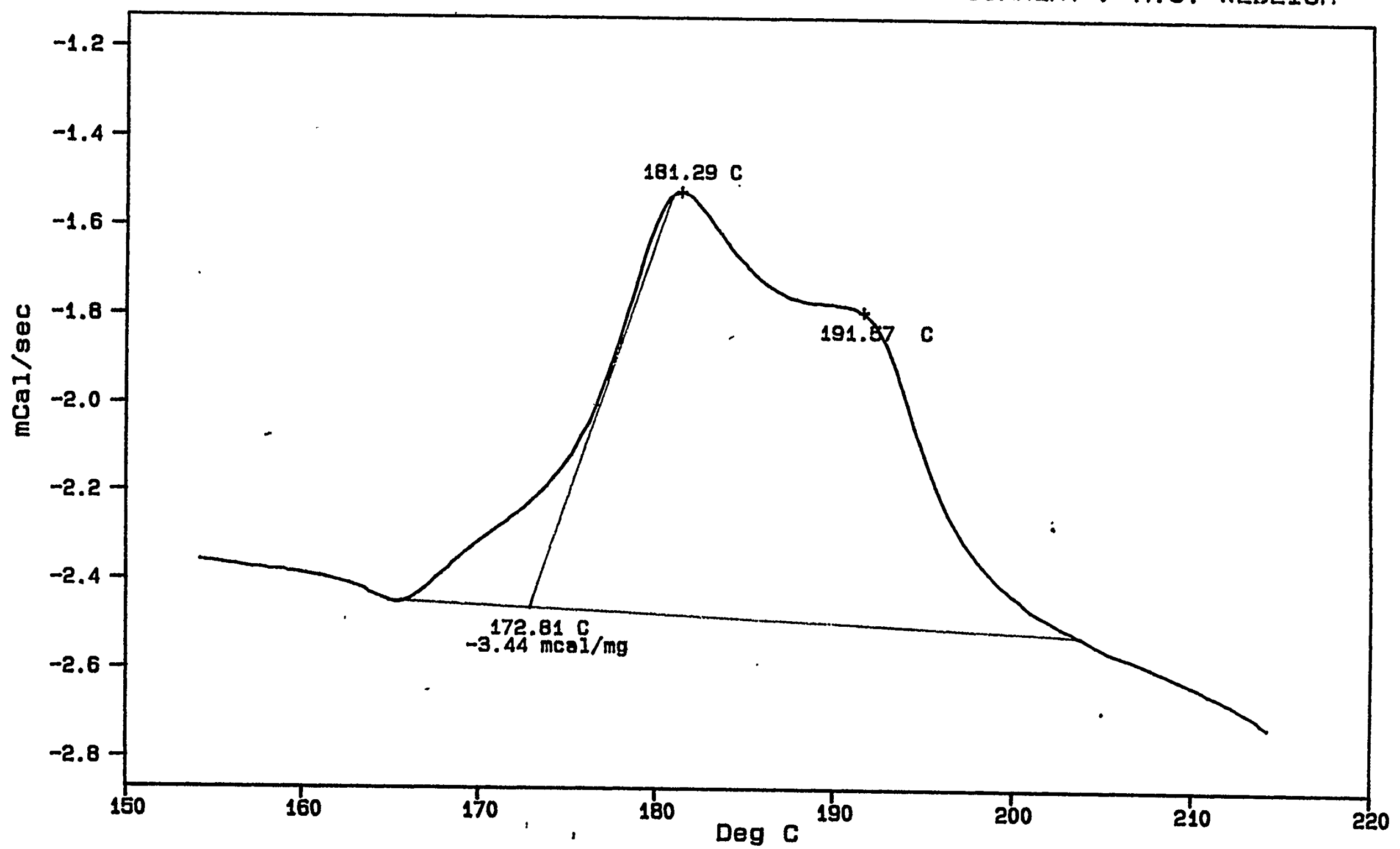

VERSION: V4.30 
FIGURB 17

$\square \longrightarrow$

PL Thermal Sciences
(Q⿻i⿵冂丶 SMPL ID : $5 \%$ In C sludge AUN ID: SIZE OPEAATOR: RCW
DATE RUN: Feb/27/1999

GAS 1: GN2

GAS 2

COMMENT : A.C. WEDLICH

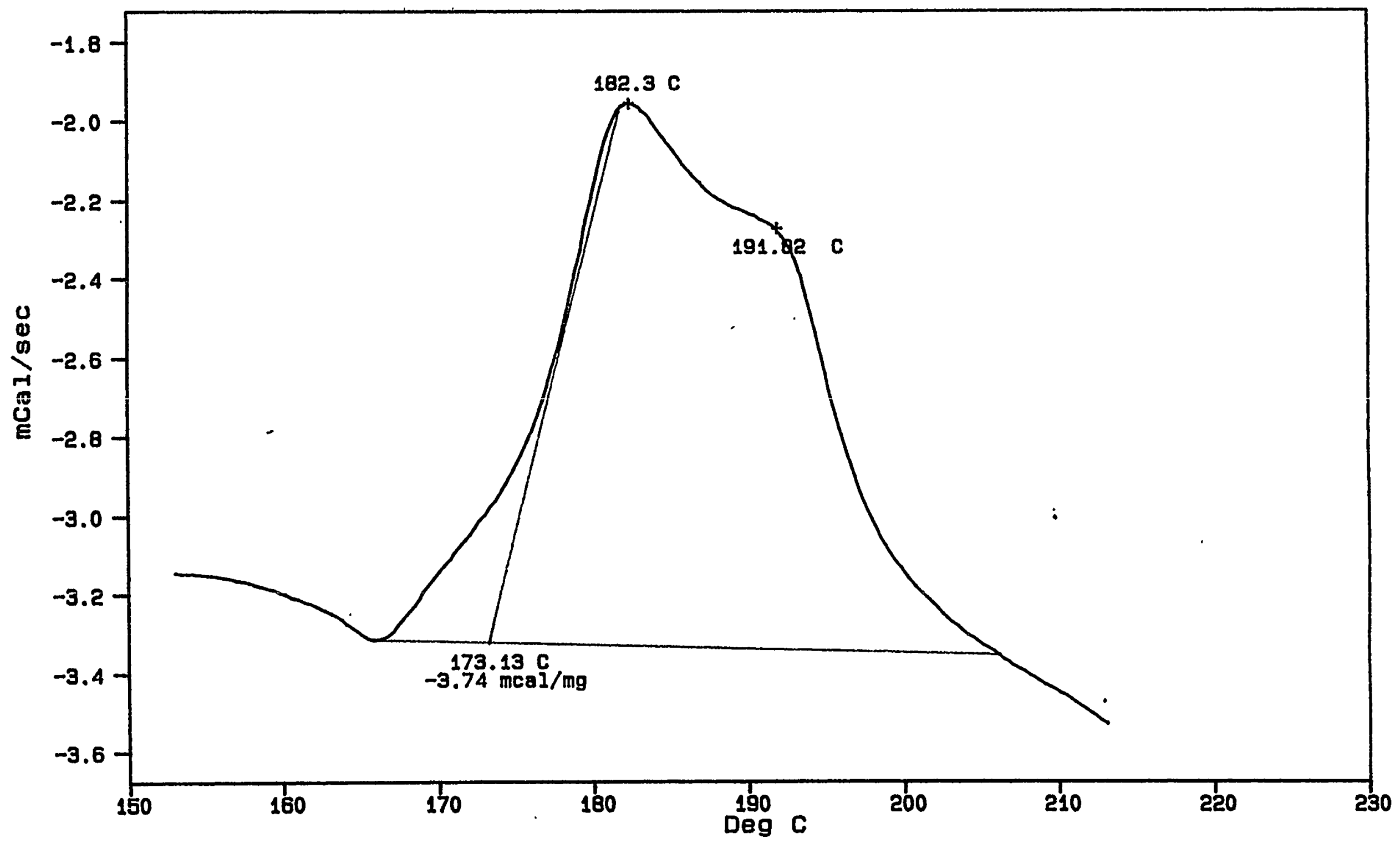


FIGURR 18

\begin{tabular}{|c|c|c|c|c|}
\hline$\underbrace{}_{\text {Thermal sciences }} C_{(G N)}$ & $\begin{array}{l}\text { SMPL ID : } \\
\text { RUN ID } \\
\text { SIZE } \\
\text { OPEAATOR: }\end{array}$ & $\begin{array}{l}10 \% \text { in C sludge } \\
13.230 \mathrm{mg} \\
\mathrm{ACW}\end{array}$ & $\begin{array}{l}\text { DATE RUN: } \\
\text { GAS } 1: \\
\text { GAS } 2: \\
\text { COMMENT : }\end{array}$ & $\begin{array}{l}\text { Feb/28/1999 } \\
\text { GN2 } \\
\text { R.C. WEDLICH }\end{array}$ \\
\hline
\end{tabular}

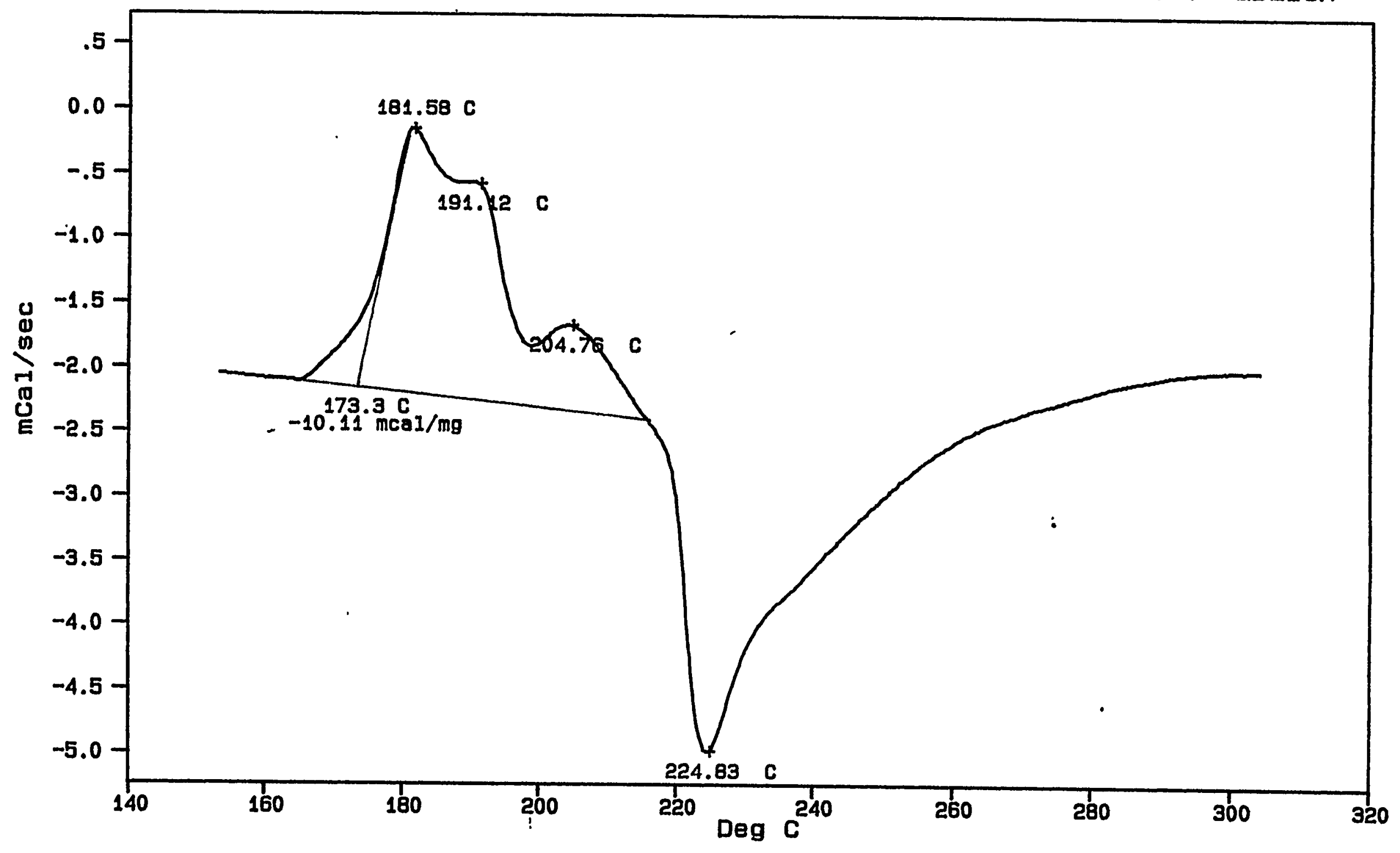

VEASTON: V4.30 
FIGURE 19

$10 \mathrm{C}$

pl. Thermal Sciences
SMPL. ID: 10\% in C sludge

RUN ID:

SIZE : $20.600 \mathrm{mg}$ OPEAATOR: RCW
DATE RUN: Feb/27/1999

GAS 1: GN2

GAS

COMMENT : R.C. WEDLICH

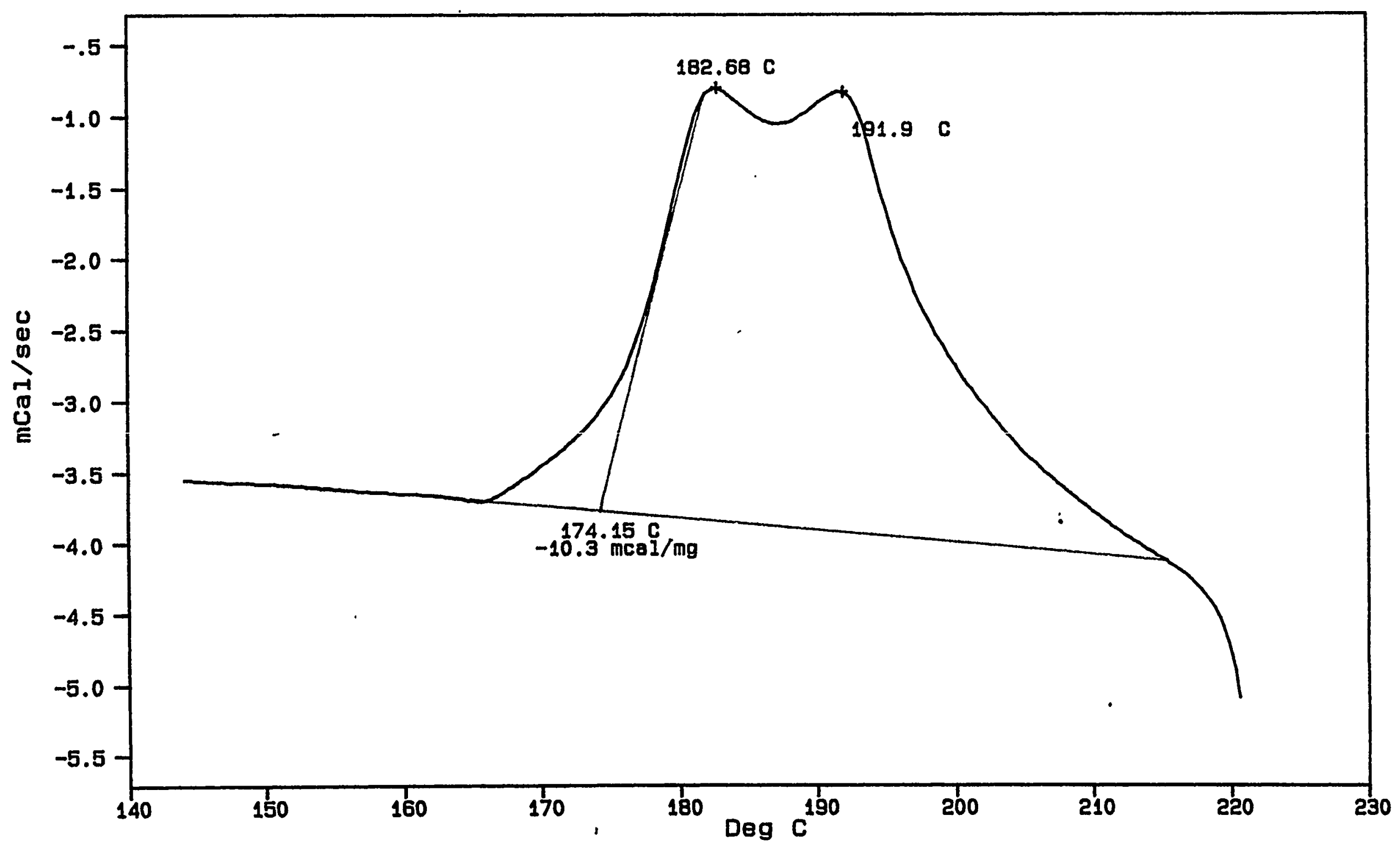

VERSTON: VA. 30 


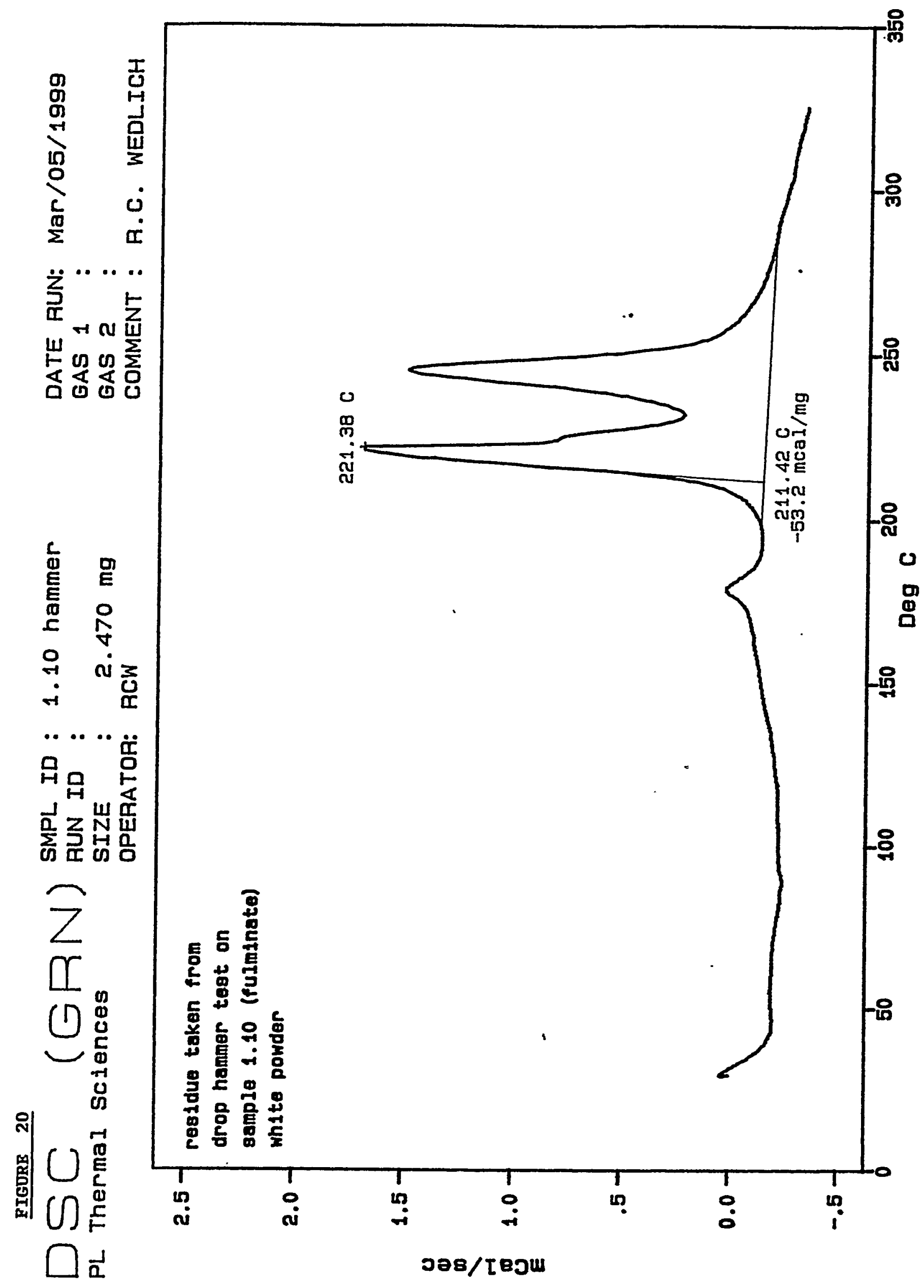

0
$\vdots$
$\vdots$
$\vdots$
$\vdots$
4
4
4 


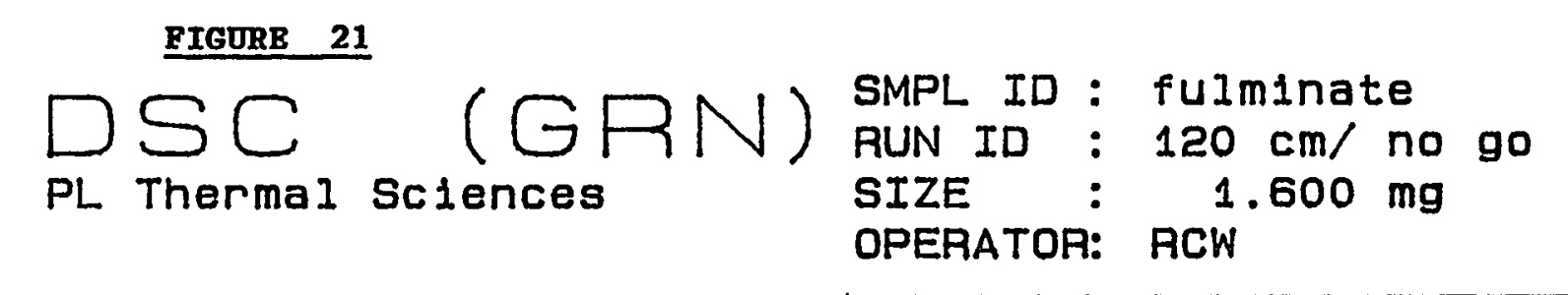

DATE RUN: Mar/04/1999

GAS 1 : GN2

GAS 2

COMMENT : R.C. WEDLICH

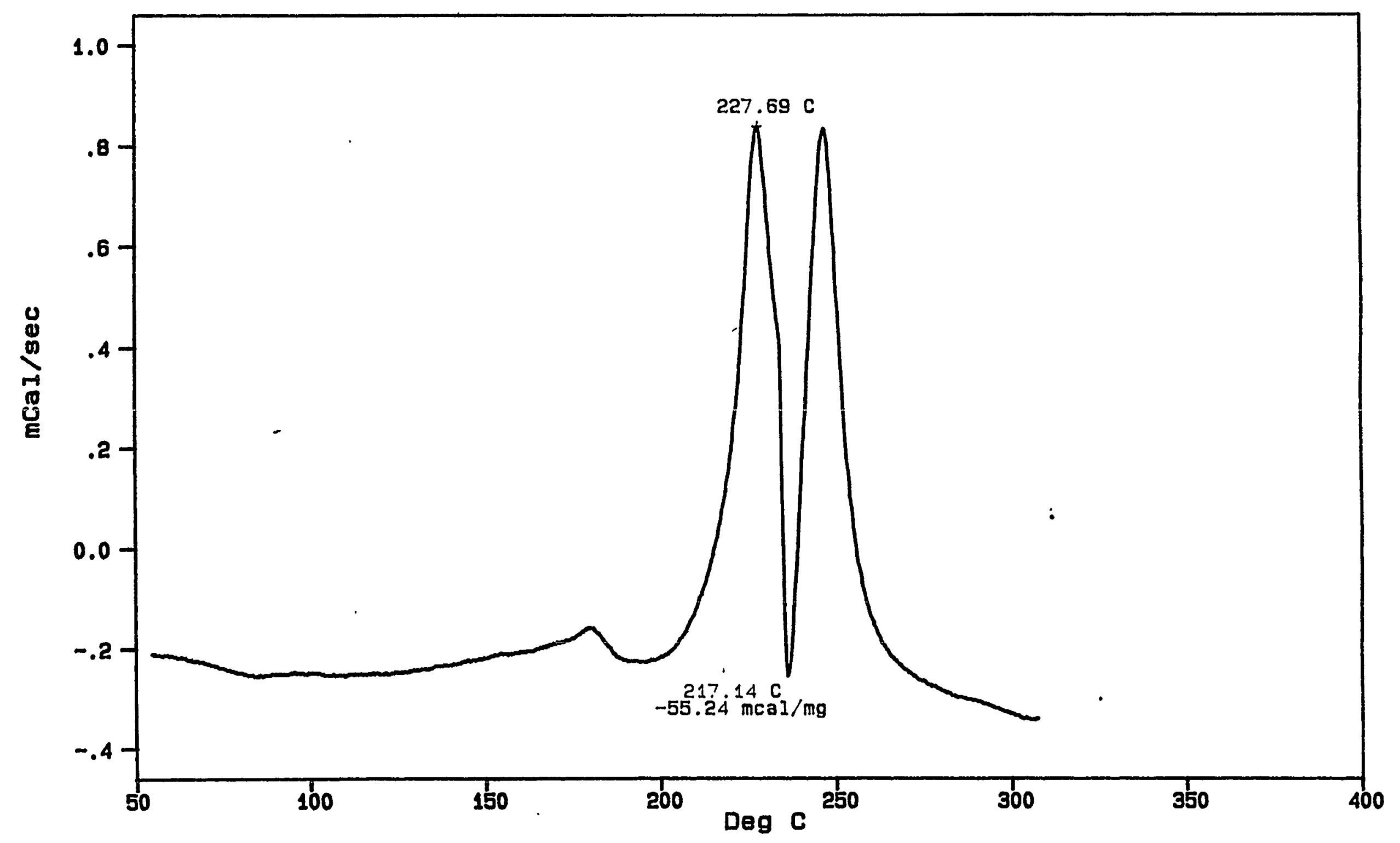


PIGURE 22

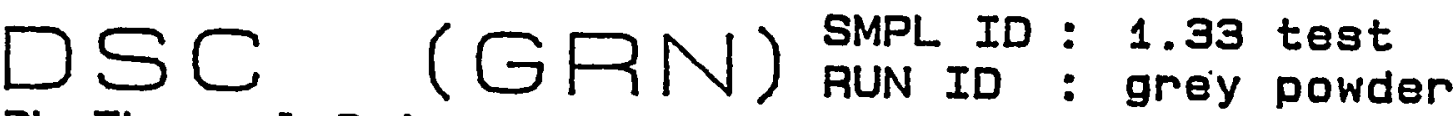

PL Thermal Sciences SIZE : $3.360 \mathrm{mg}$ OPERATOR: RCW
DATE RUN: Mar/05/1999

GAS 1

GAS 2

COMMENT : R.C. WEDLICH

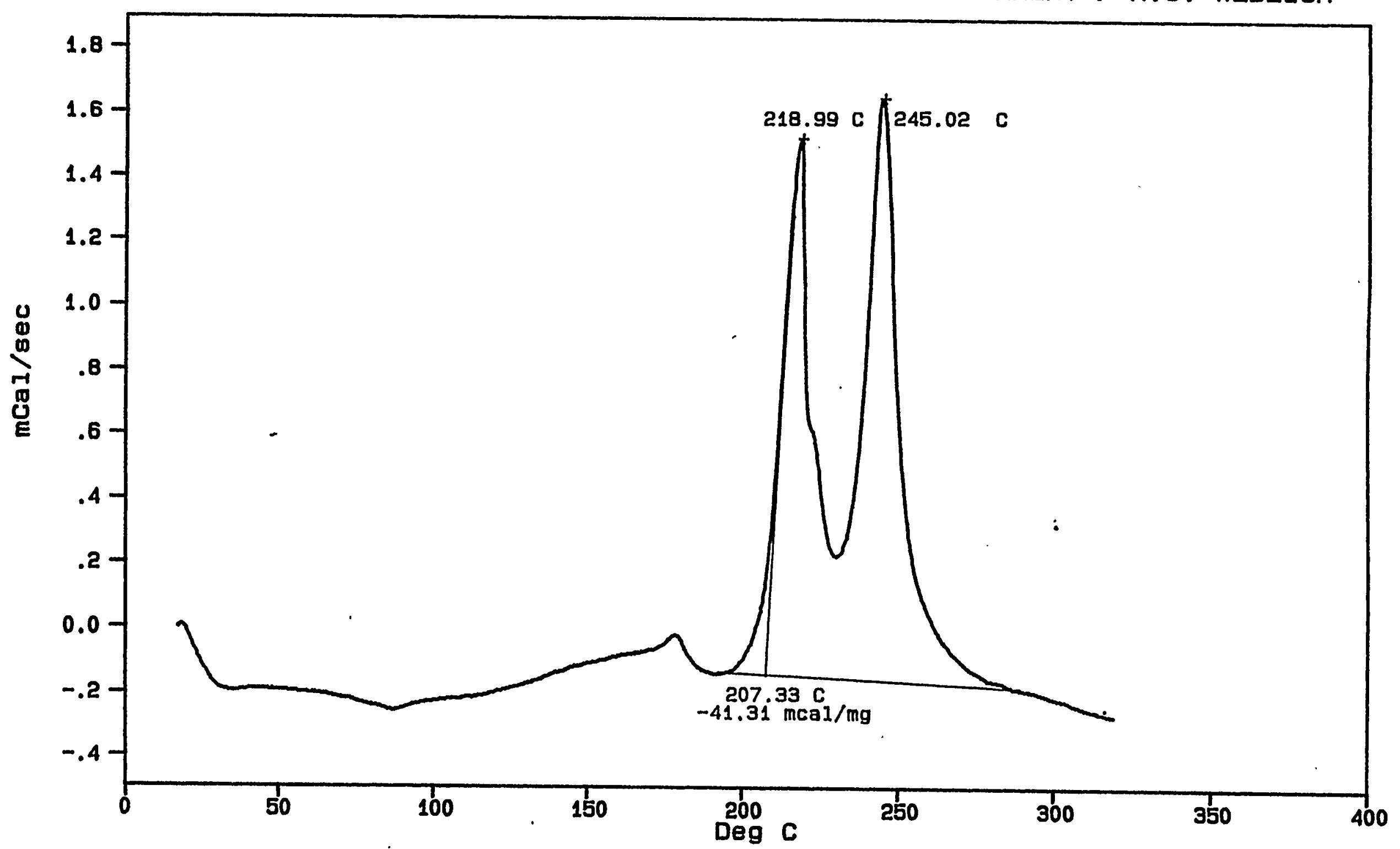

VERSION: VA.30 


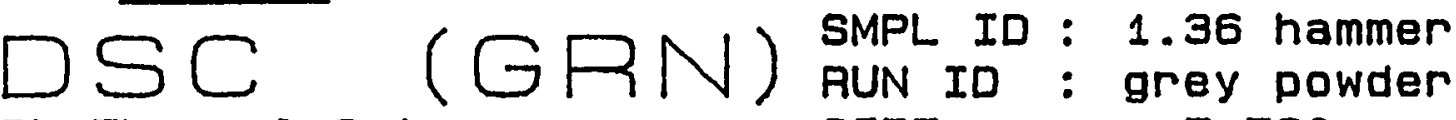 \\ PL Thermal Sciences \\ SIZE OPERATOR: RCW}

DATE RUN: Mar/05/1999

GAS 1

GAS 2

COMMENT : R.C. WEDLICH

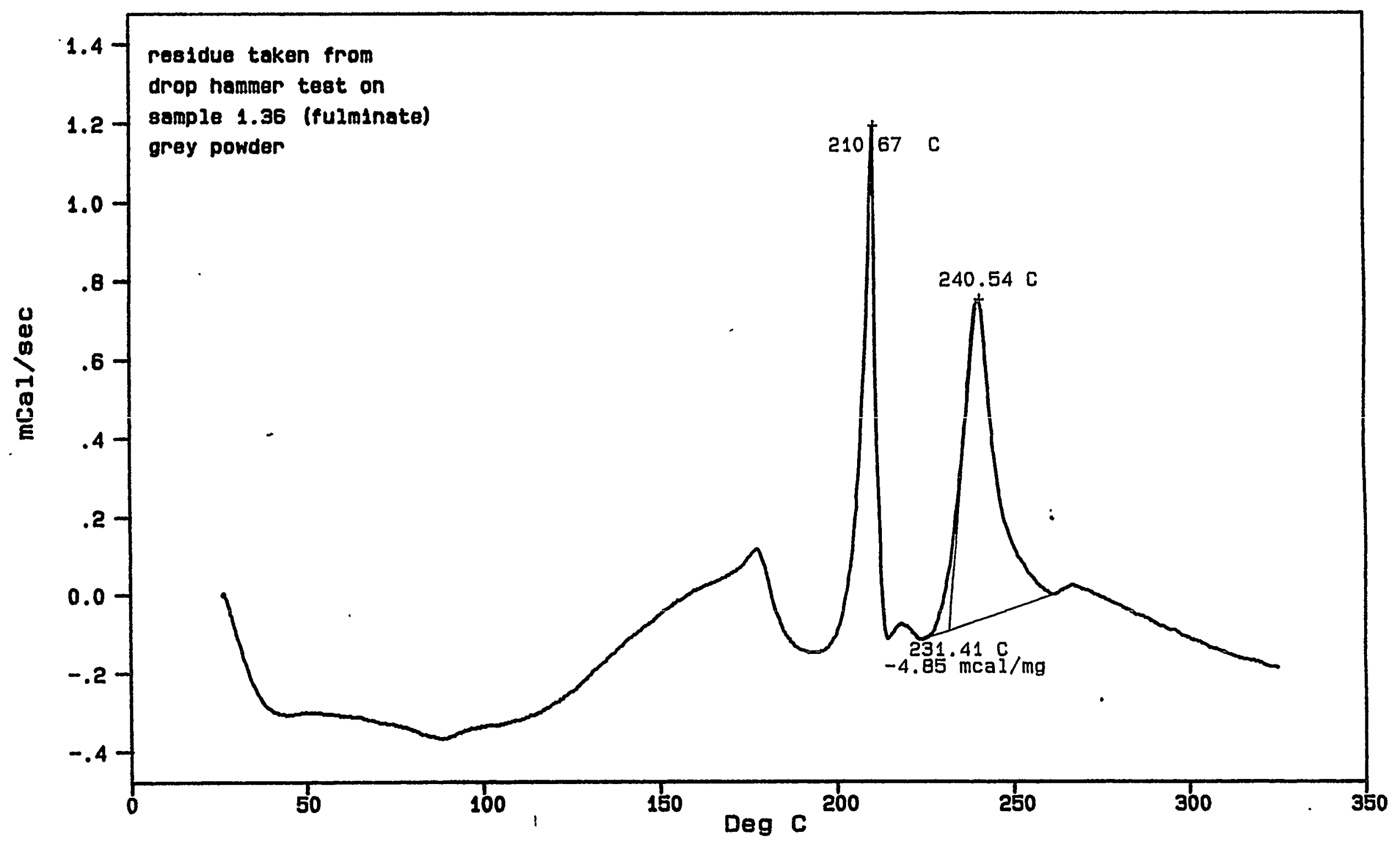


FIGURE 24

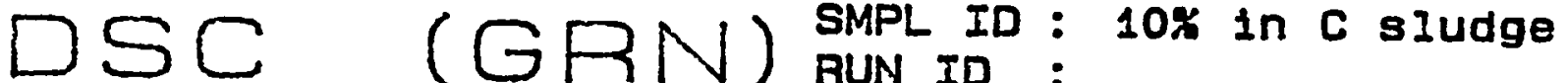

PL Thermel Scjences
SIZE : $13.230 \mathrm{mg}$ OPERATOR: RCW
DATE RUN: Feb/28/1999 GAS 1: GN2 GAS 2 COMMENT : A.C. WEDLICH

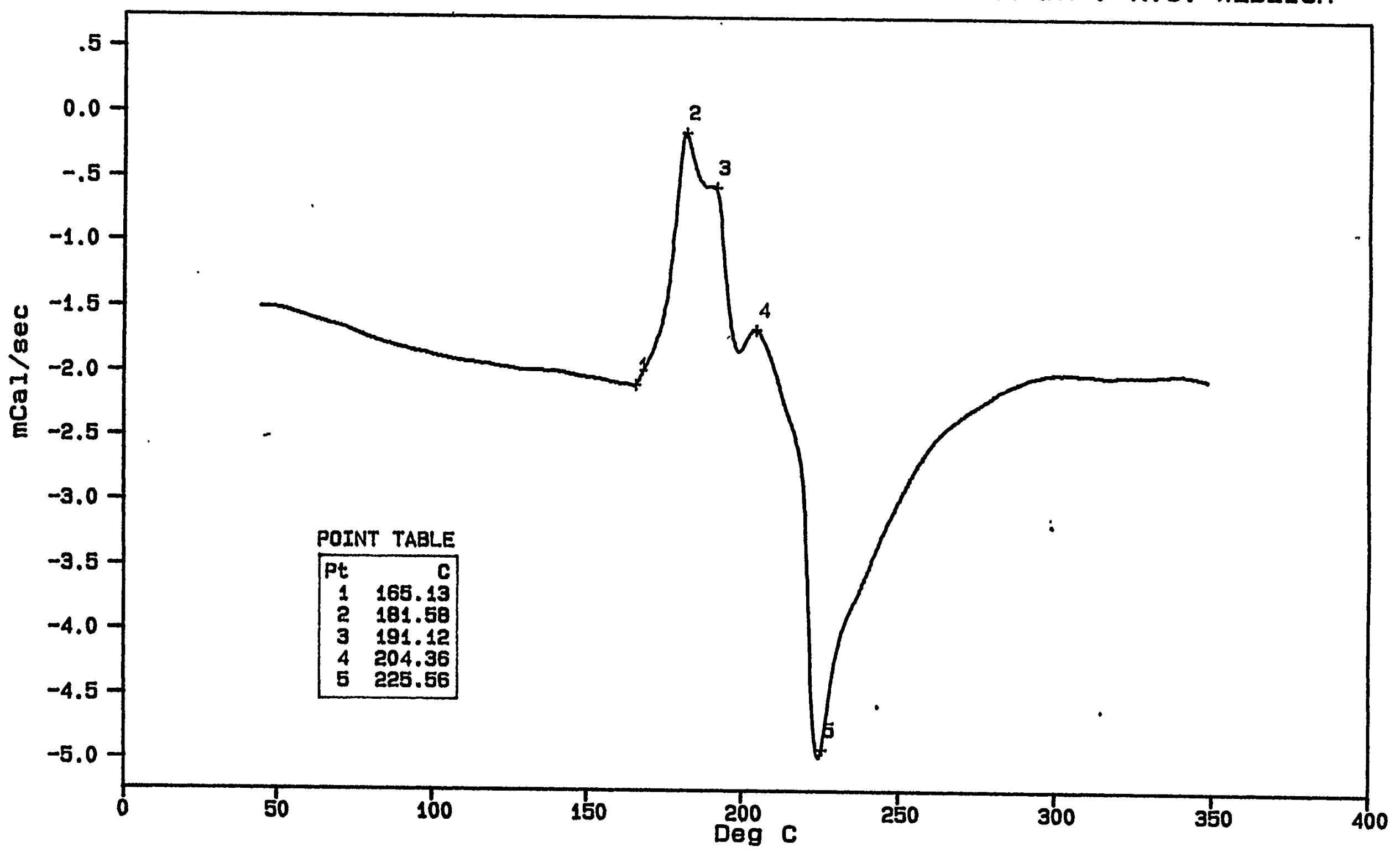

VEASION: VA.30 
FIGURE 25

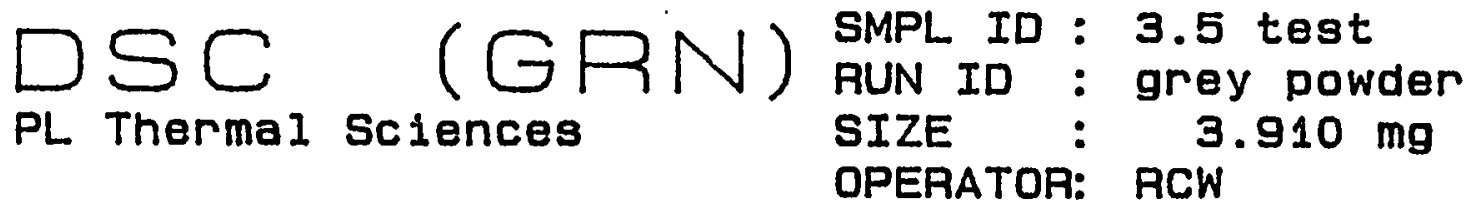

DATE RUN: Mar/06/1999

GAS 1

GAS ?

COMMENT : R.C. WEDL.ICH

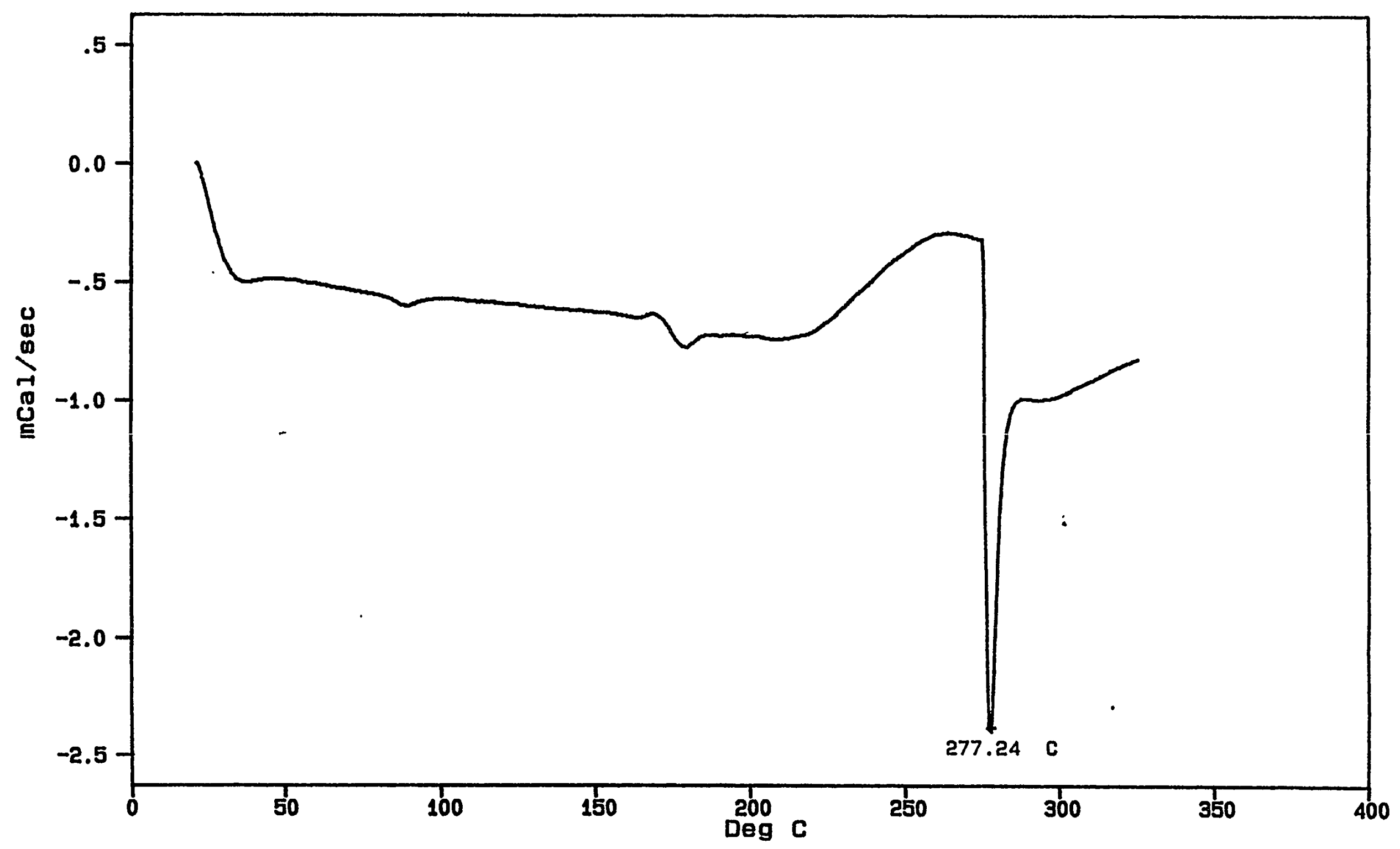


FIGURB 26

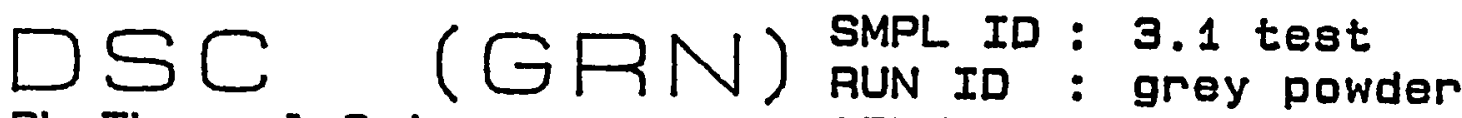

PL Thermal Sciences

DATE RUN: Mar/06/1999

SIZE : $7.070 \mathrm{mg}$

GAS 1

GAS 2

OPERATOR: RCW

COMMENT : R.C. WEDLICH

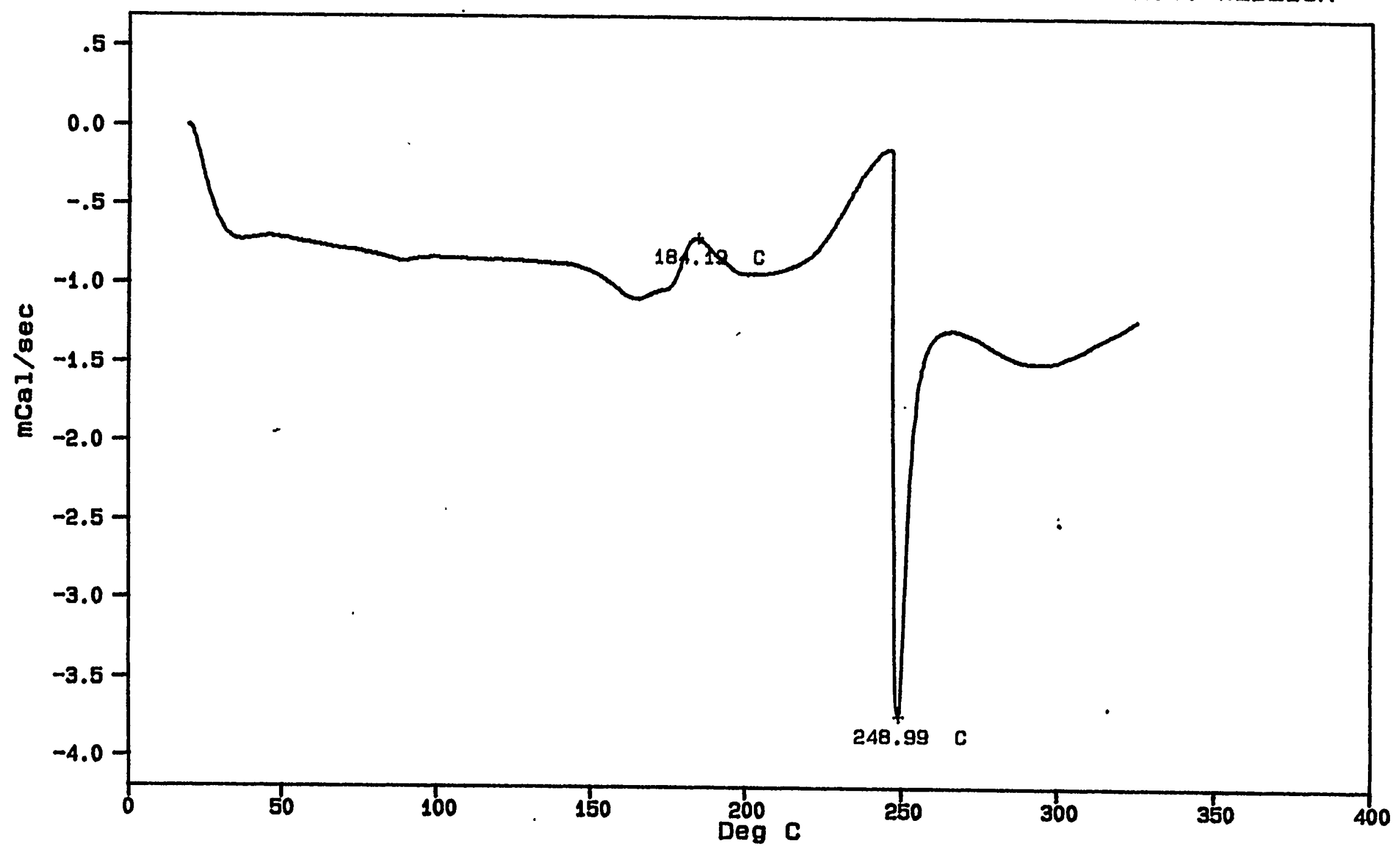

VEASION: VA.3O 


\section{APPENDIX 5}

I

। 


\section{Guidelines for Chemical Reaction Hazard Evaluation}

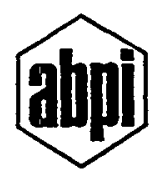

The Association of the British Pharmaceutical Industry

12 Whitehall London SW1A 2DY

Telephone 01-930 3477

Telex 298916 


\subsubsection{Interpretation}

The result can be rated on the basis of the time taken to propagate combustion for. a given distance and the ratings will range from non-combustible to highly combustible.

\subsection{Closed Tube Test ${ }^{3}$}

\subsubsection{Objectives}

- To detect the 'onset temperature' of an exotherm and of any concurrent gas evolution and to obtain an estimate of their energy and volume.

- To examine for delayed onset of reaction and to estimate the rate when gas evolution has been detected.

\subsubsection{Principle}

A 10 gramme sample is sealed in a small Carius tube which is placed in an air oven heated at $2^{\circ} \mathrm{C}$ minute. The temperature at the centre of the sample and the pressure are recorded continuously.

If gas evolution is detected it can be studied in more detail under isothermal conditions.

\subsubsection{Sensitivity}

Onset is detected when the rate of temperature rise is $5-10^{\circ} \mathrm{C} /$ hour above the heating rate.

\subsubsection{Method}

a) Equipment (Figure 3)

- Pyrex tube (35 millilitres) with re-entrant thermocouple pocket and adaptor with glass/metal joint on the outlet.

- Stainless steel tube from the outlet with capillary bore filled with oil or grease to transmit pressure (but not corrosive gases) to a transducer in a cooler area.

- 70 bar pressure transducer.

- Shaker.

- Furnace which can withstand rupture of the tube and burning of the contents.

b) Operation

- About 10 grammes or 10 millilitres of material is placed in the tube.

- The furnace is ramped up automatically at $2^{\circ} \mathrm{C} /$ minute (the tube temperature lags by about $30^{\circ} \mathrm{C}$ ).

- Automatic cut-outs may be set at $400^{\circ} \mathrm{C}$ and $50 \mathrm{bar}$.

- Oven temperature, sample temperature and sample pressure are monitored continually (Figures $4 a$ and $4 b$ ).

\subsubsection{Interpretation}

Data can be collected on a point or continuous trace recorder and analysed visually. Microprocessor logging allows a more detailed analysis.

- 'Onset temperature' is determined by a deviation from the heating rate (at about $5-10^{\circ} \mathrm{C} /$ hour).

- The peak height or area under the curve indicate the order of magnitude of the exotherm.

- The logarithm of pressure (corrected for air pressure) can be plotted against the reciprocal of absolute temperature. Vapour pressure gives a straight line and upward deviation indicates gas evolution.

- Residual pressure on cooling indicates permanent gas generation, and its quantity can be obtained from the relative volumes of liquid and gas space in the tube. 
Figure 4a Adirect display of oven temperature, sample temperature and pressure for a closed tube heated at $2^{\circ} \mathrm{C} /$ minute.

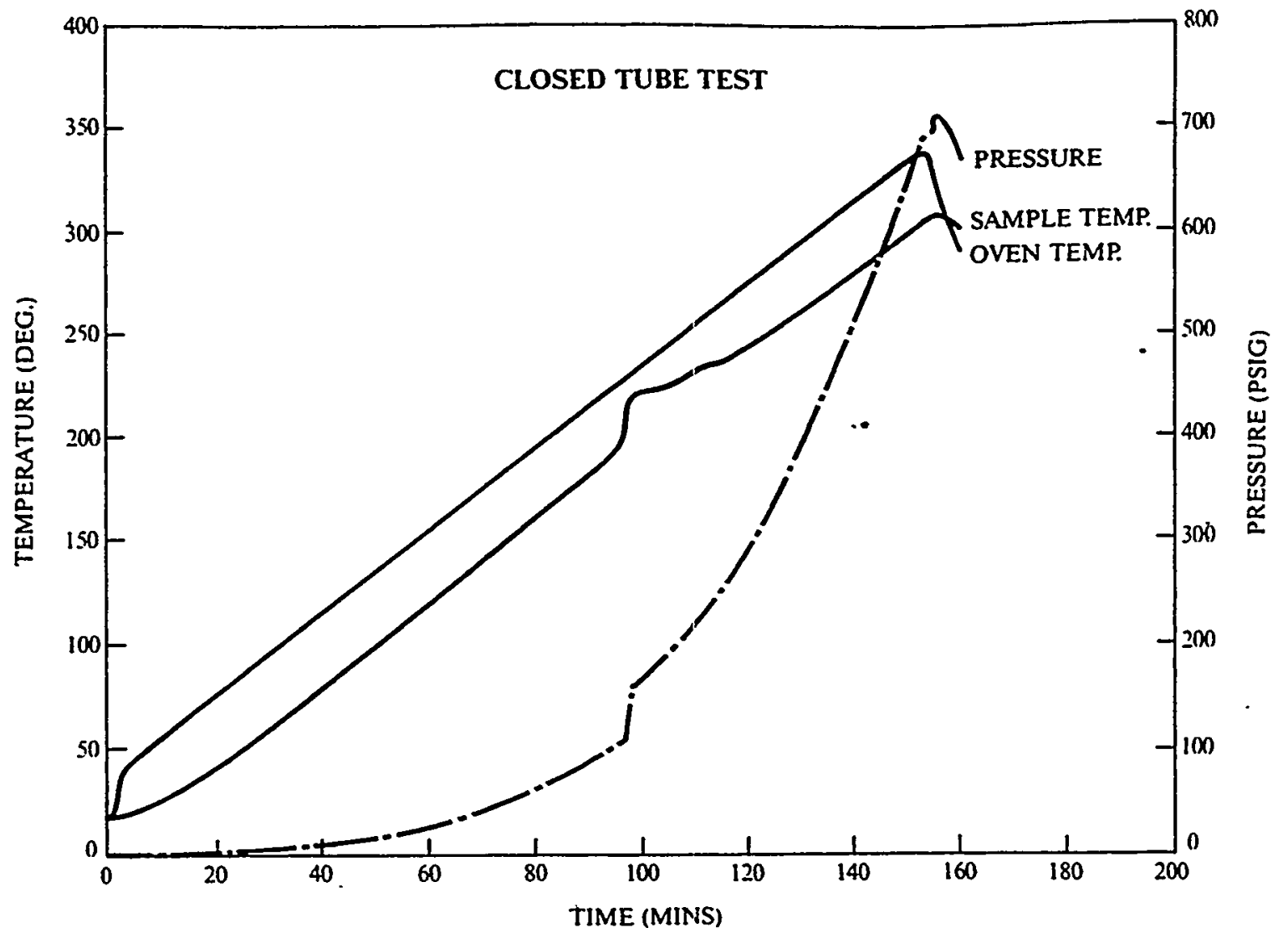

Figure $4 b$ Sample temperature deviation is displayed using a programme which automatically detects onset at $8^{\circ} \mathrm{Clhour}$.

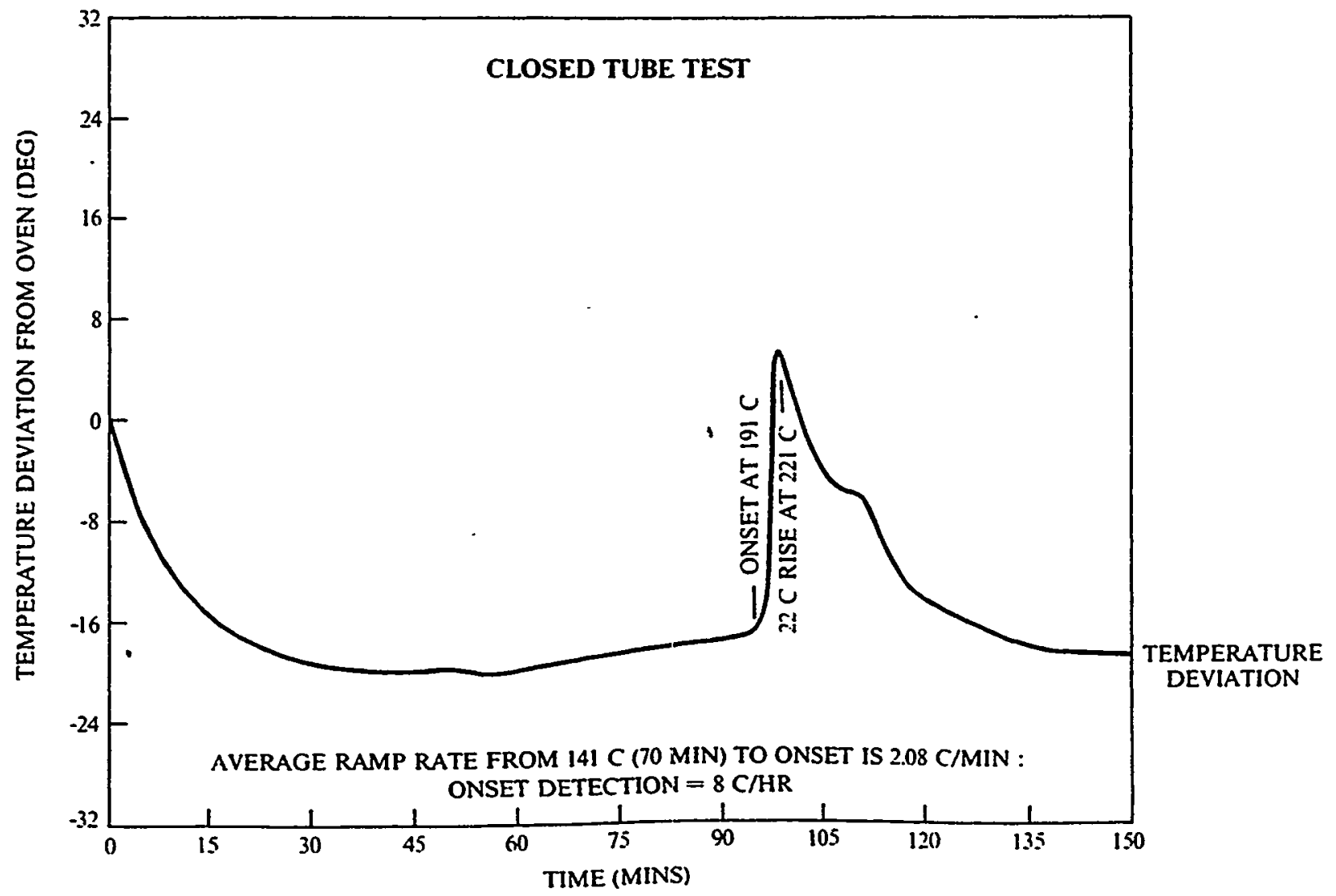


The following eight graphs refer to the data obtained through Carius Tube testing. For more details concerning the data, please reference the report sections, "Results" and "Discussion." 


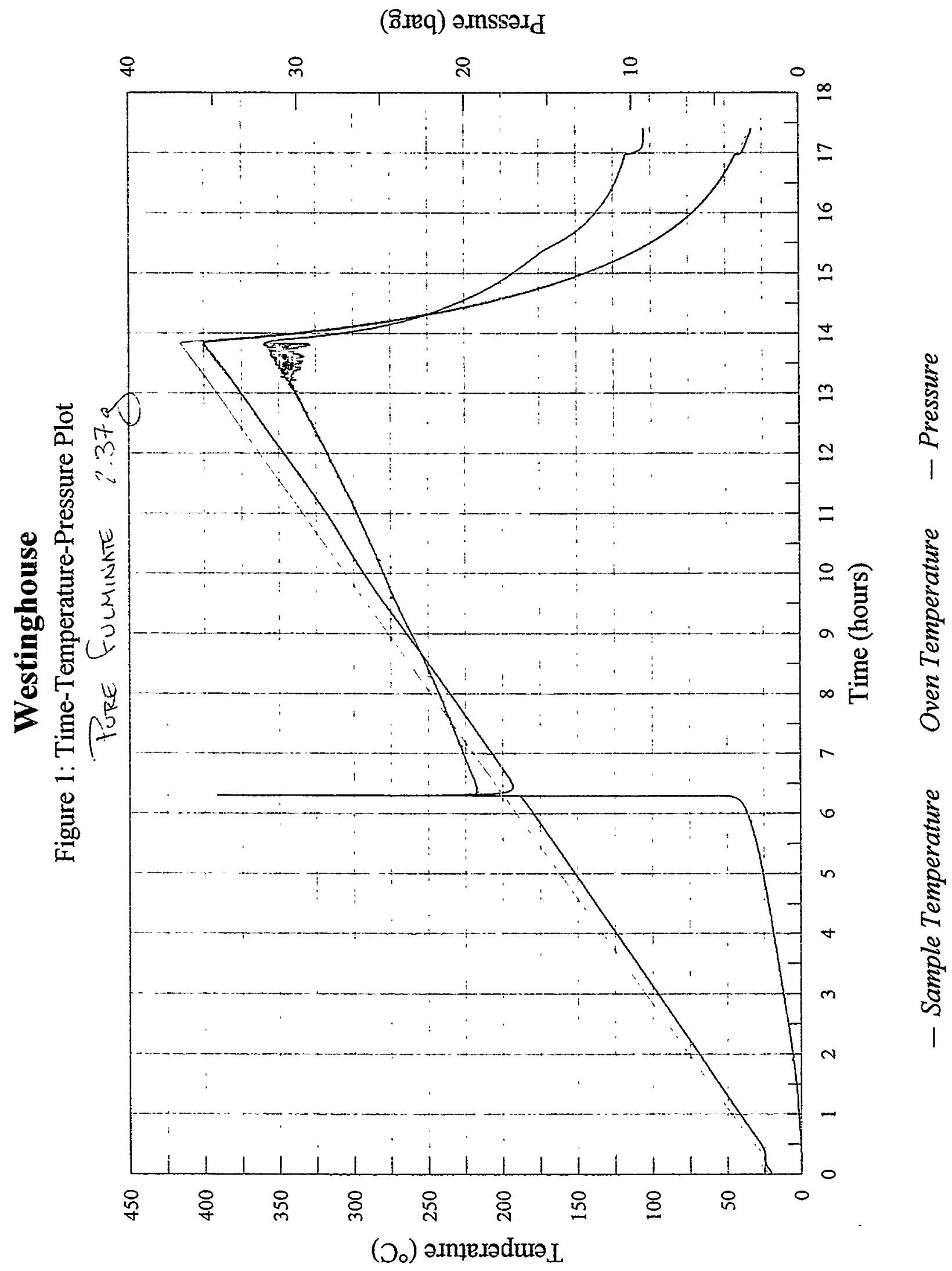

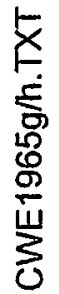




\section{Westinghouse}

Figure 1: Time-Temperature-Pressure Plot

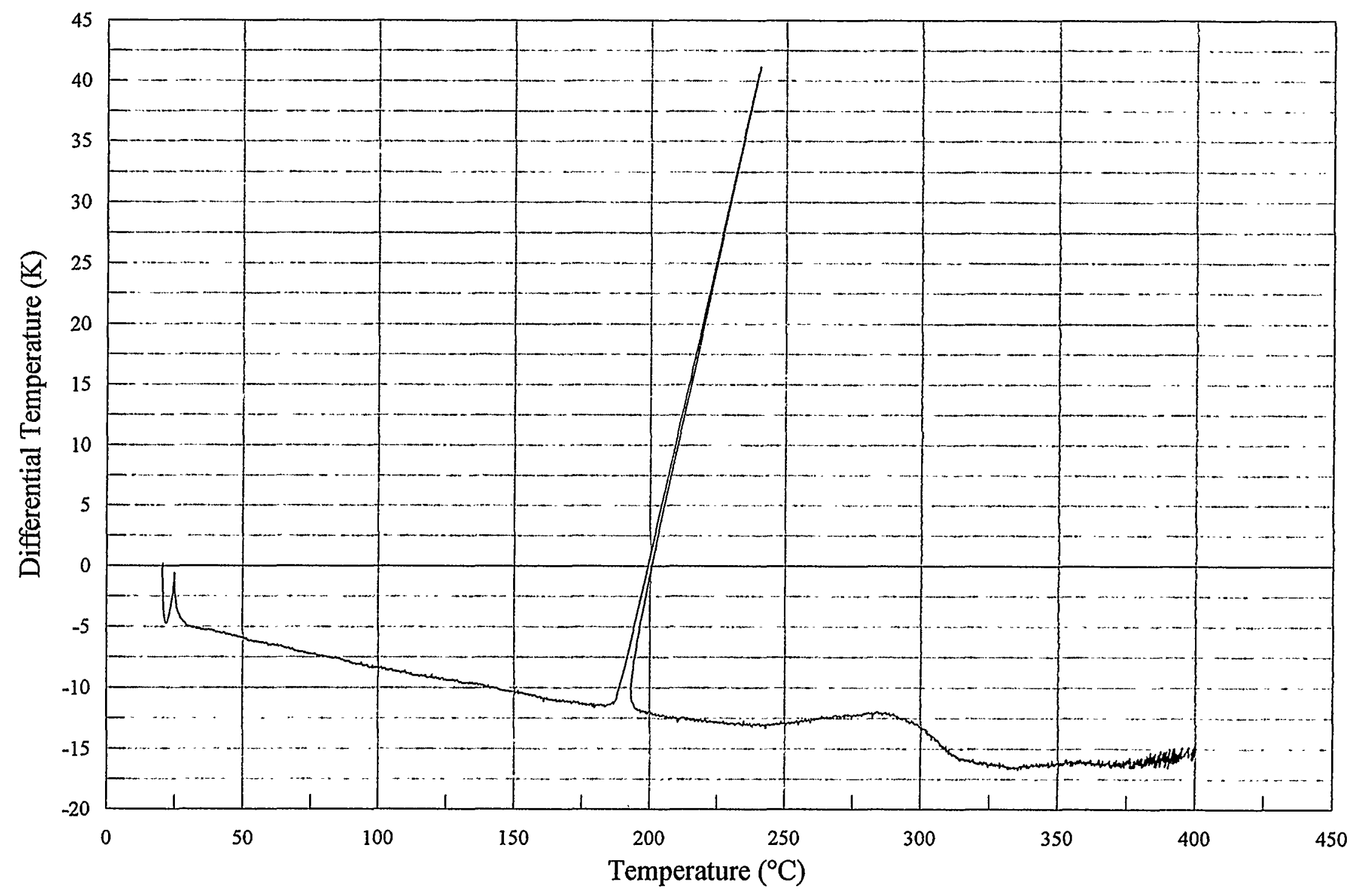

CWE1965g/h.TXT 


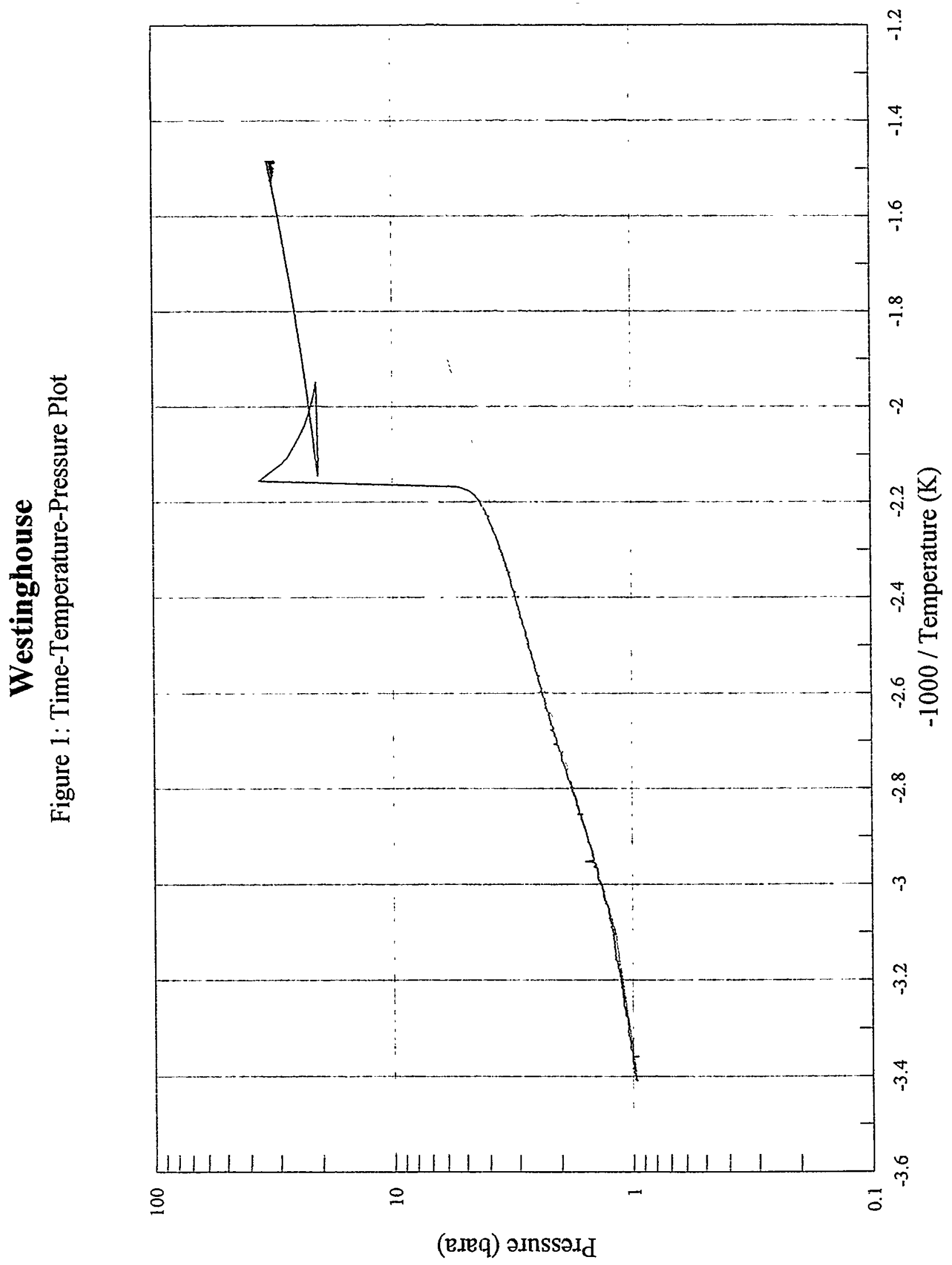




\section{Westinghouse}

Run 1: 10\% Mercury Fulminate in Caustic Sludge

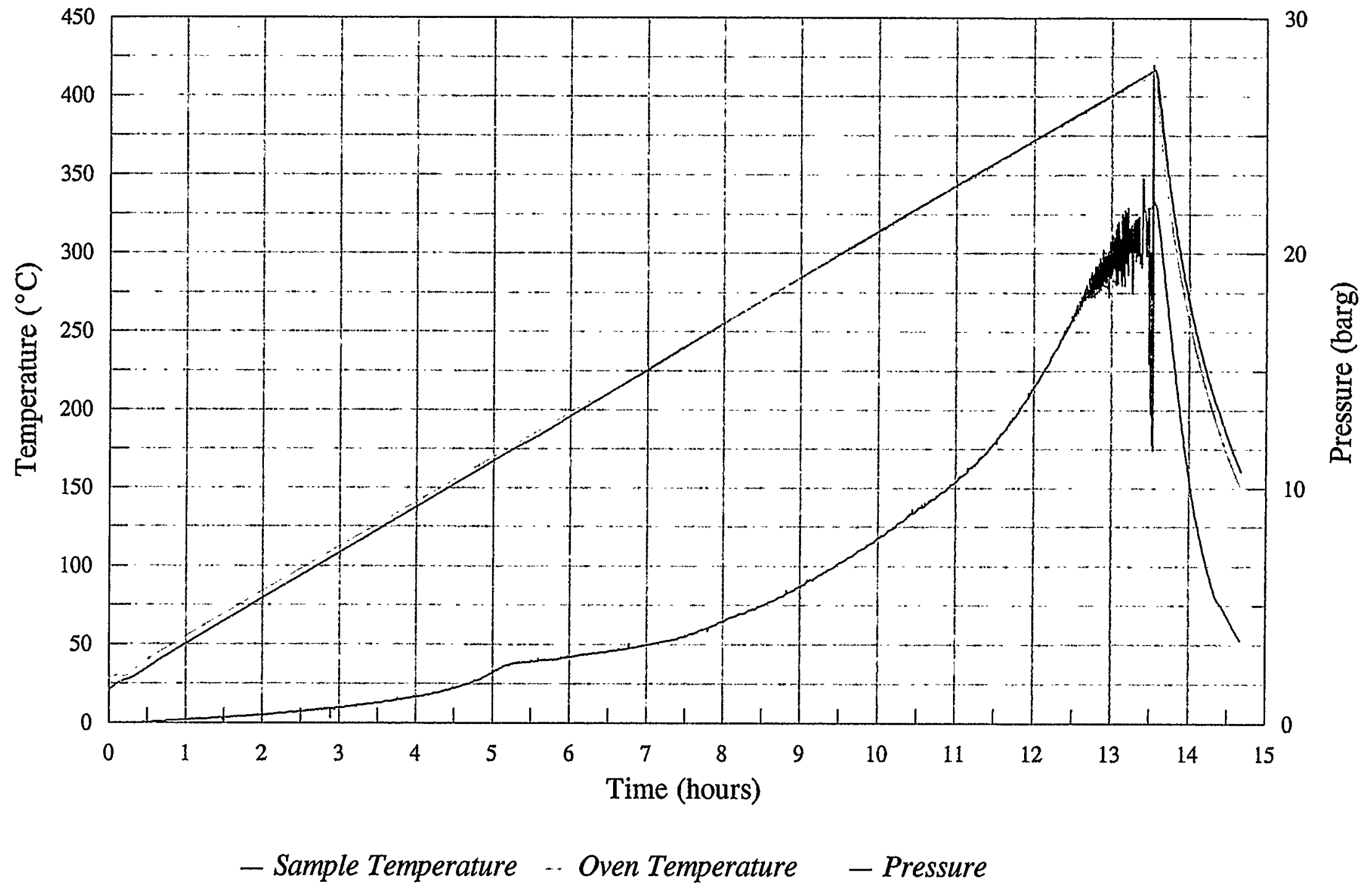




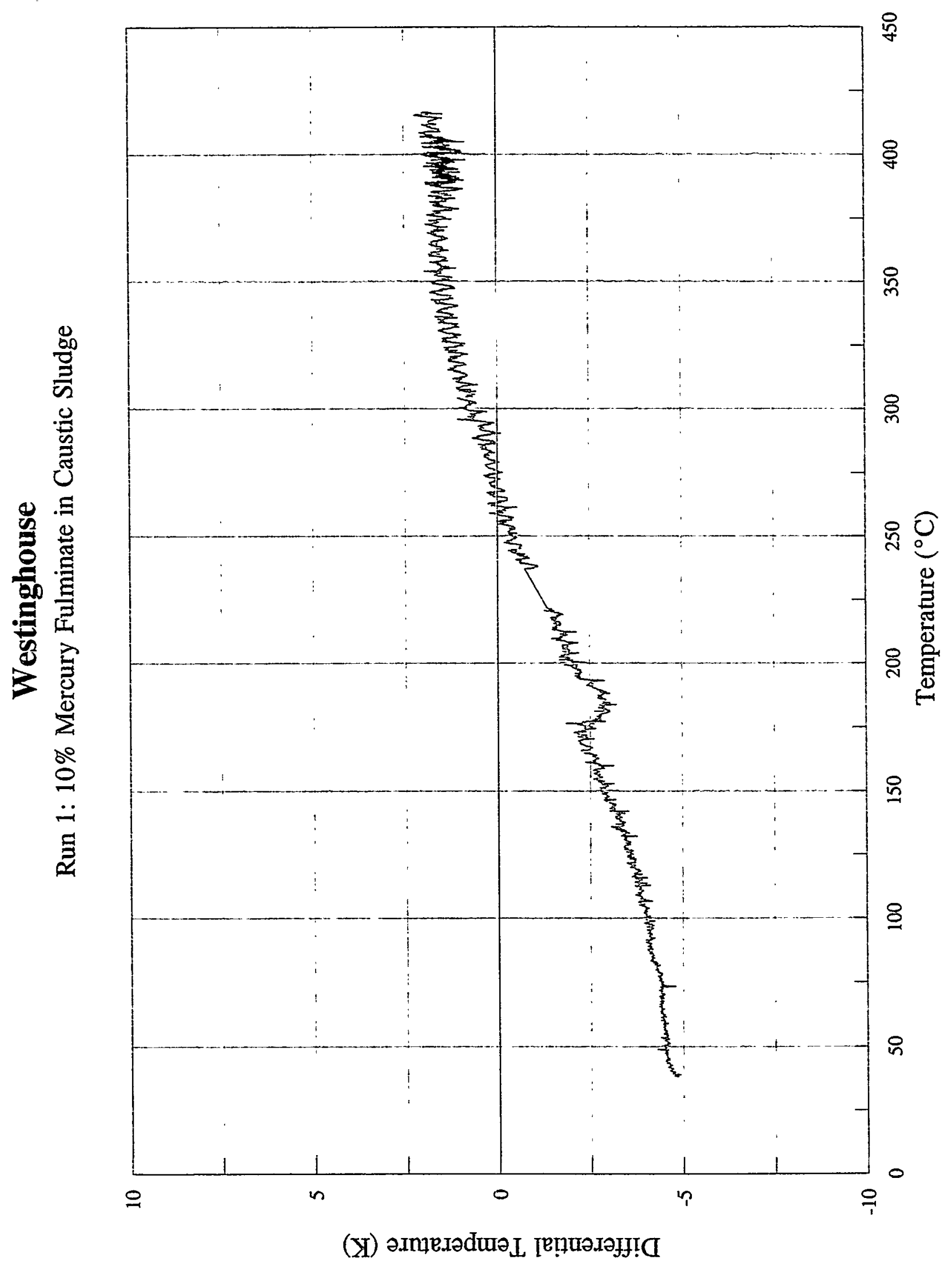

苛 


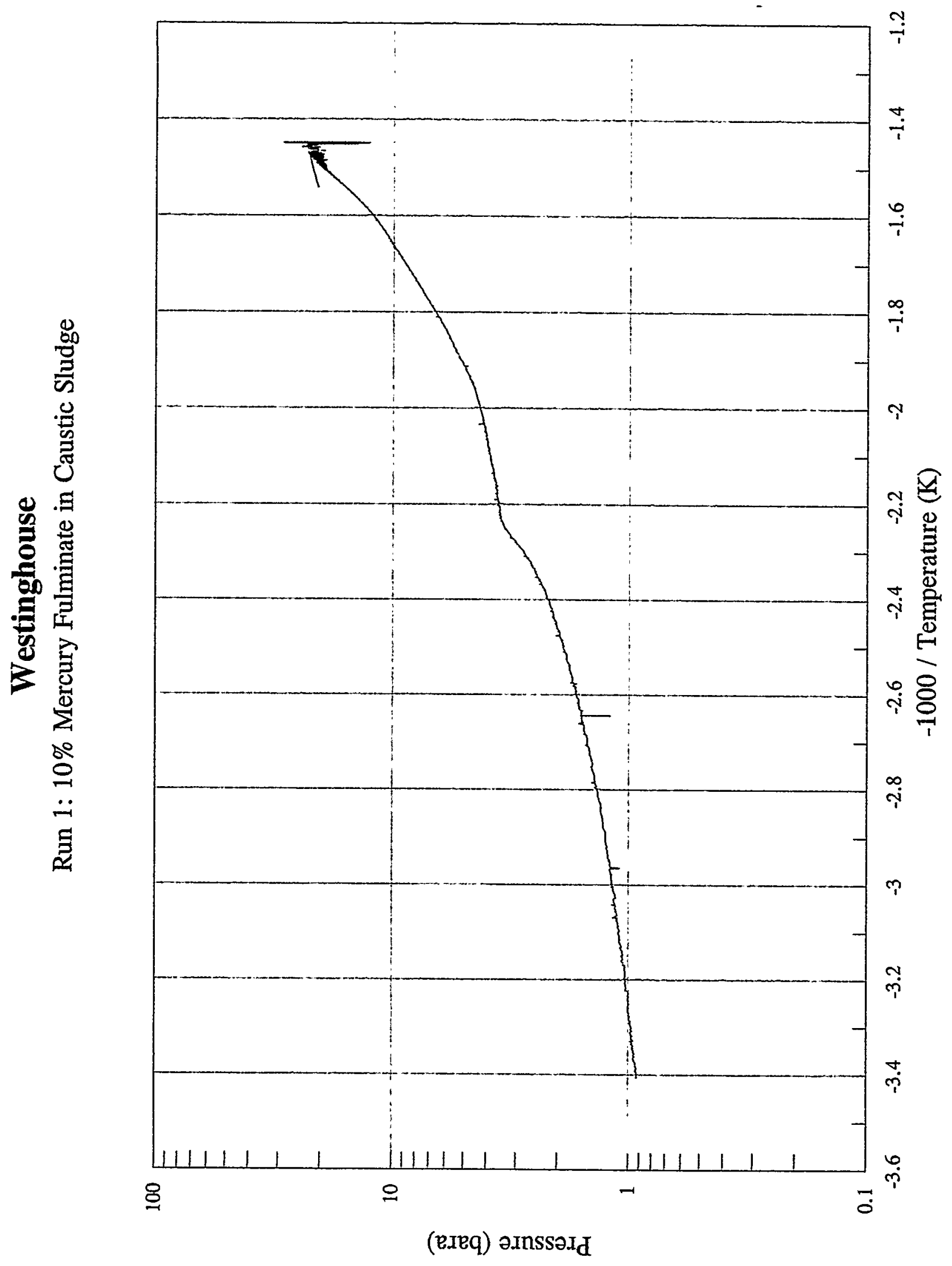




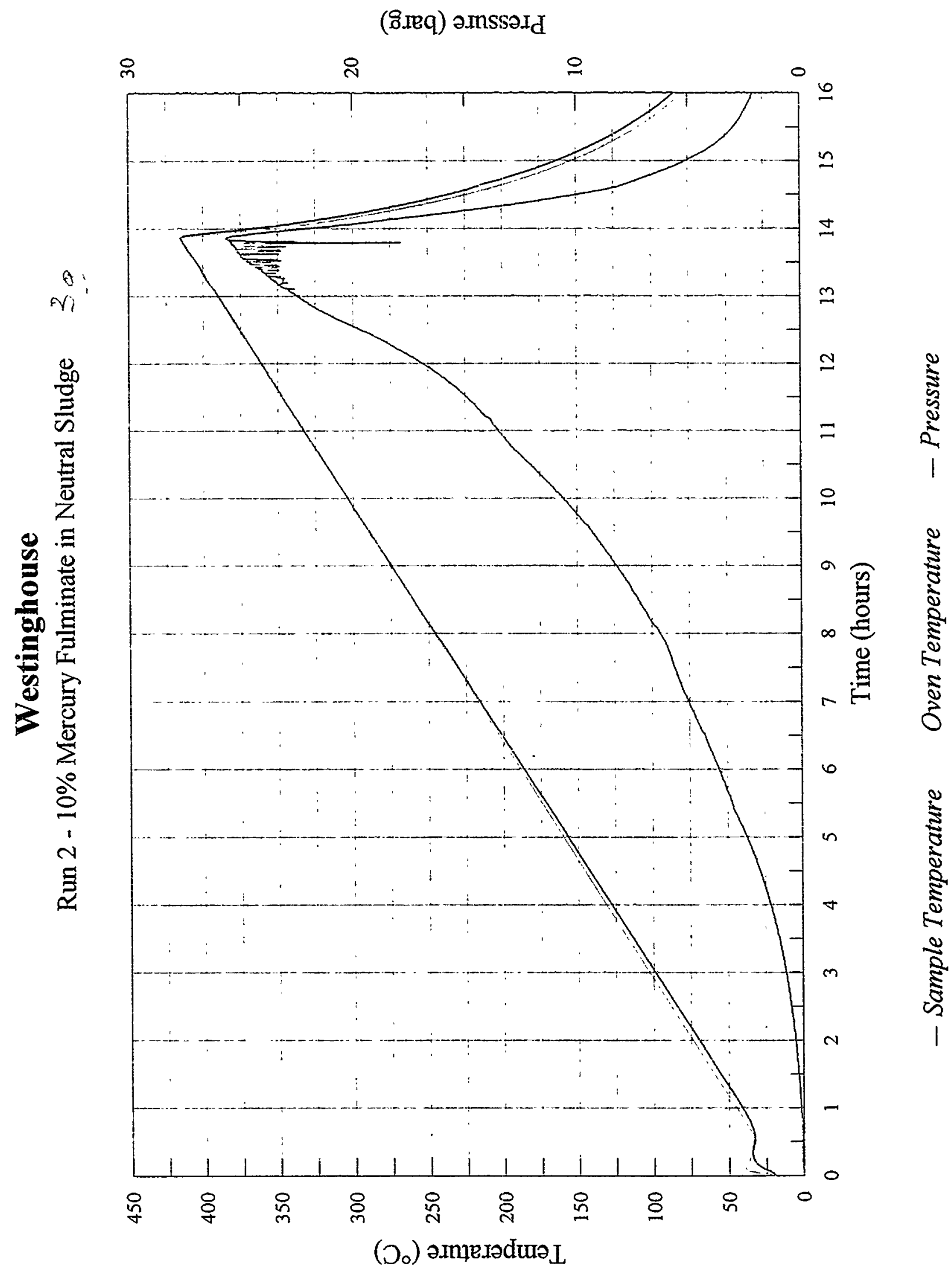




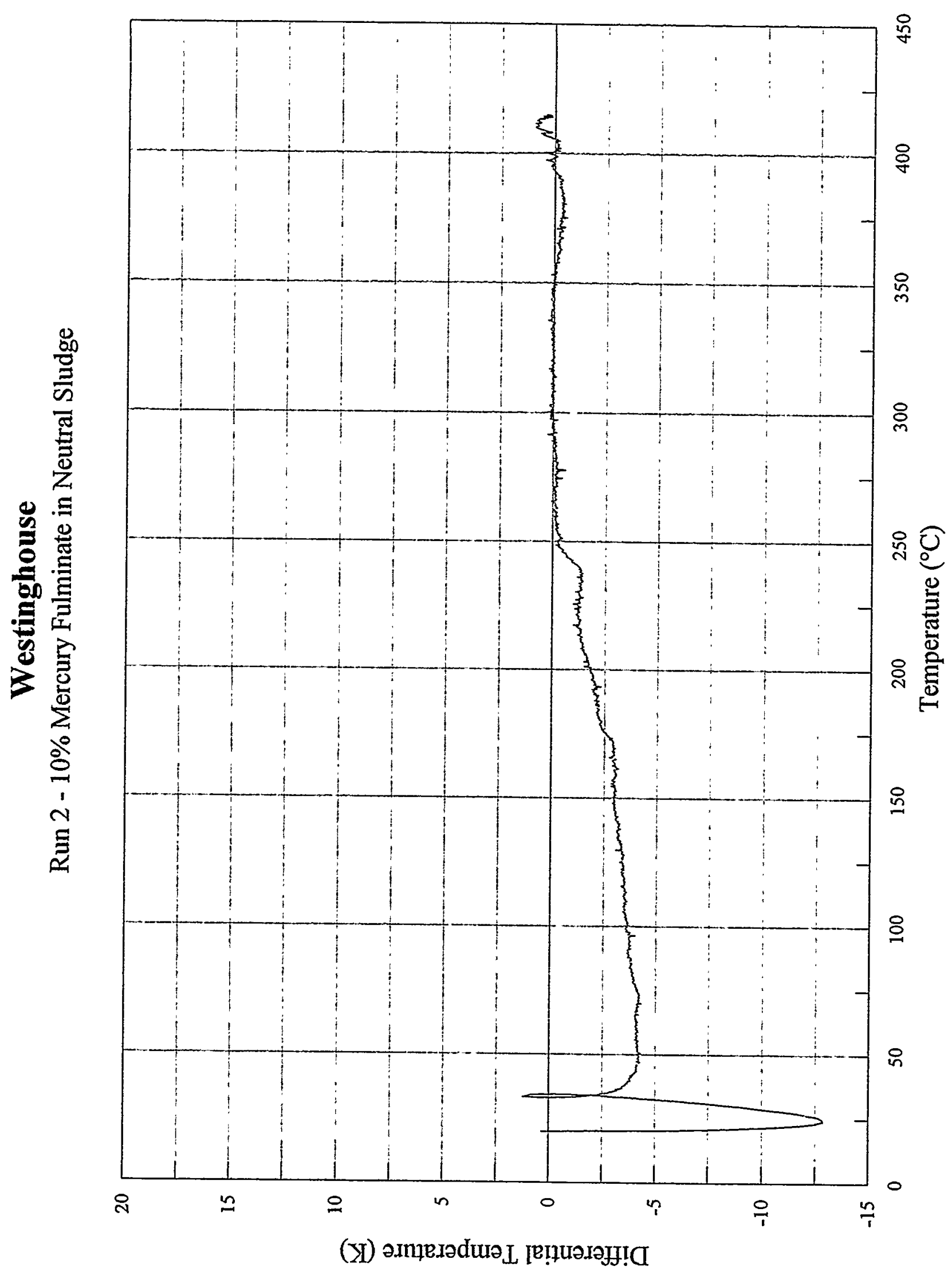

苛 


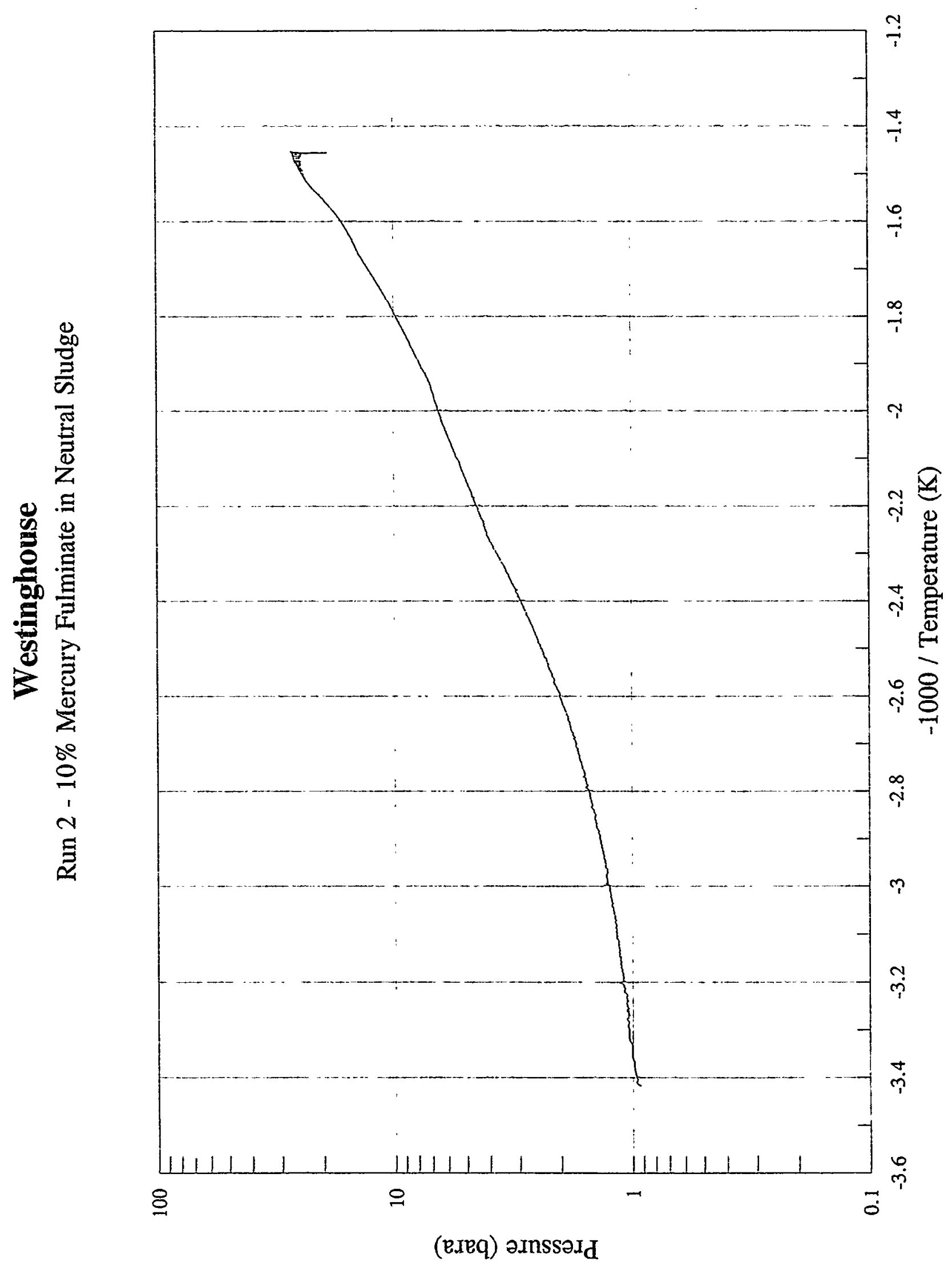




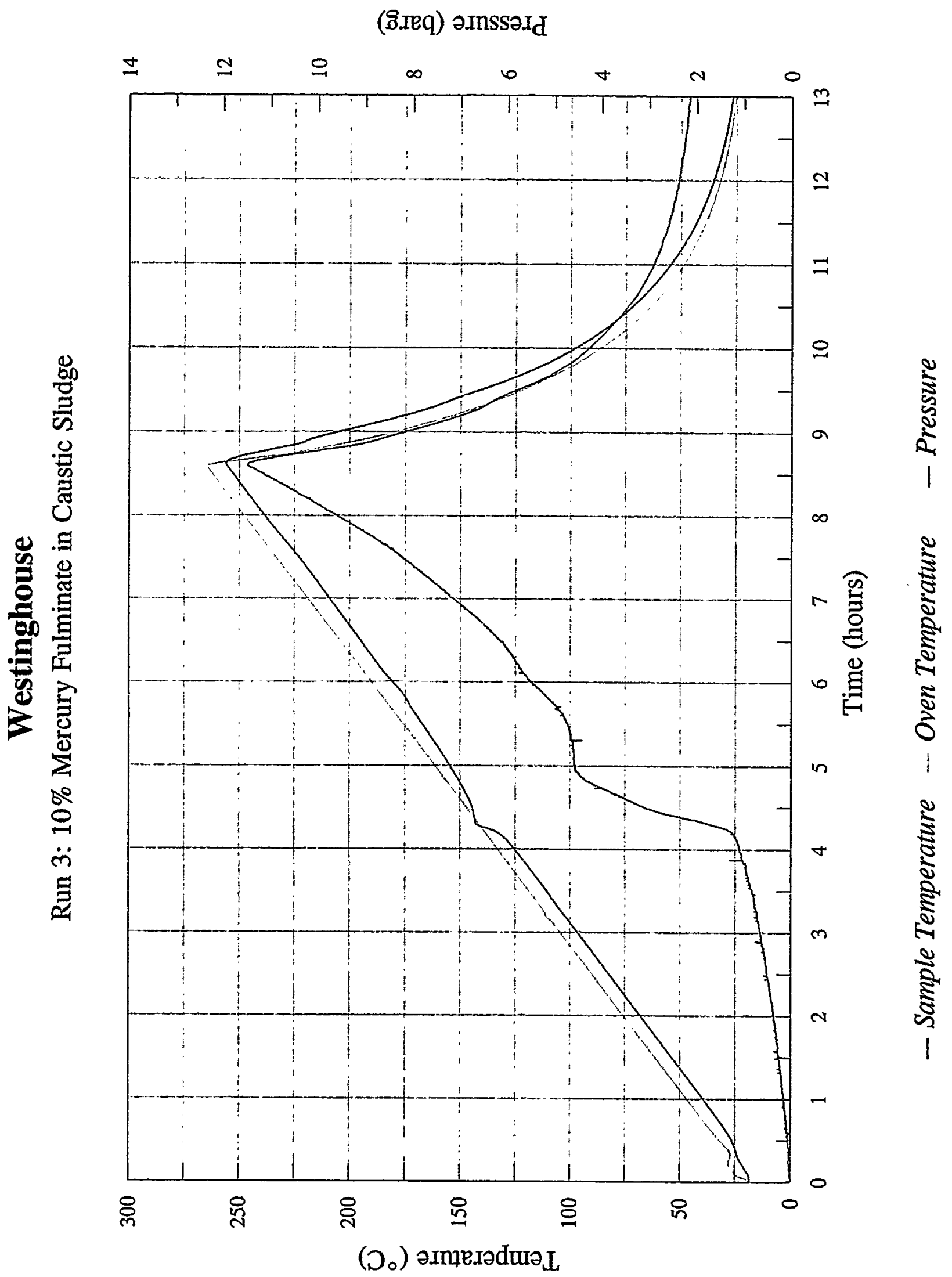

卡 


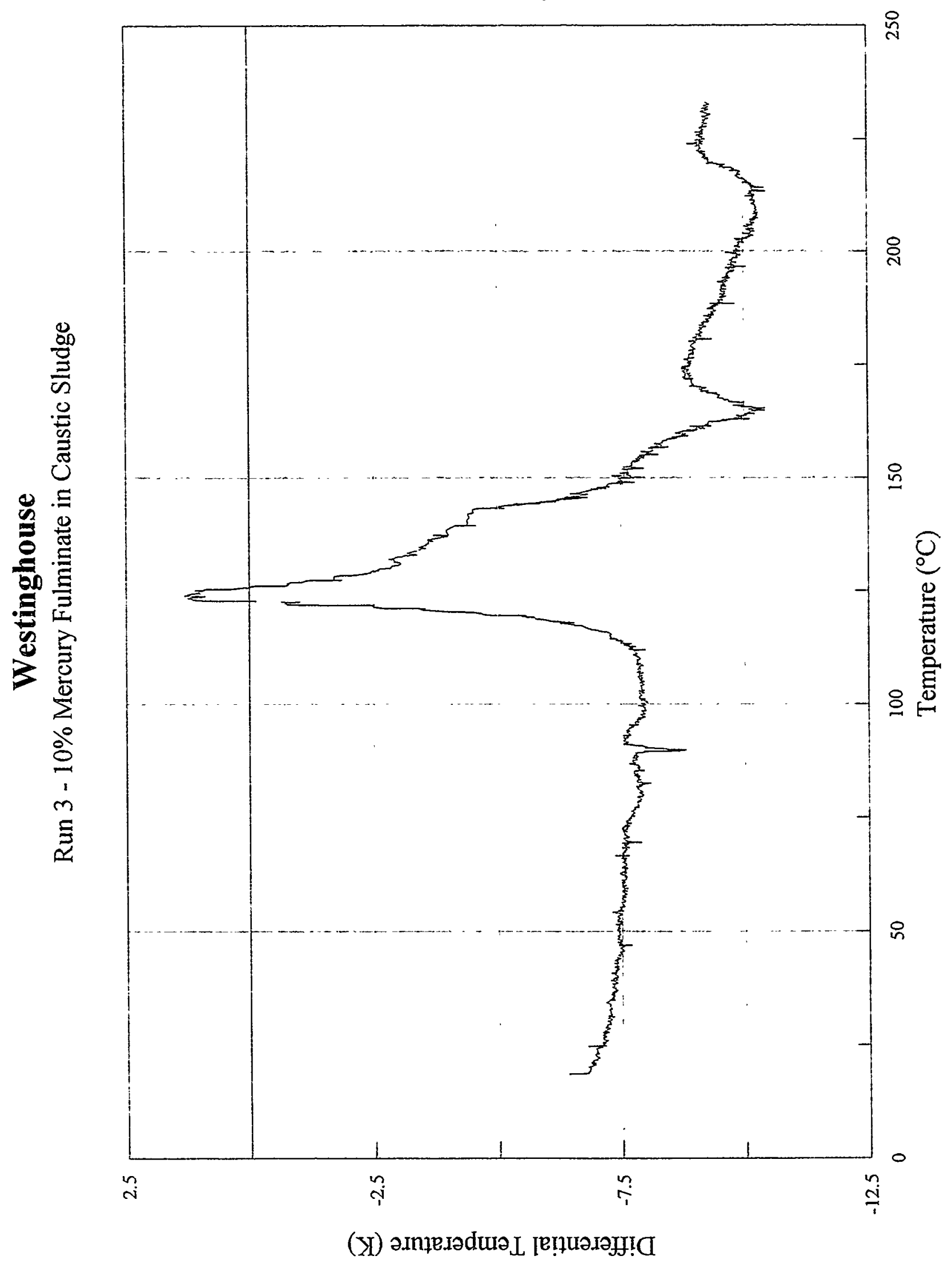




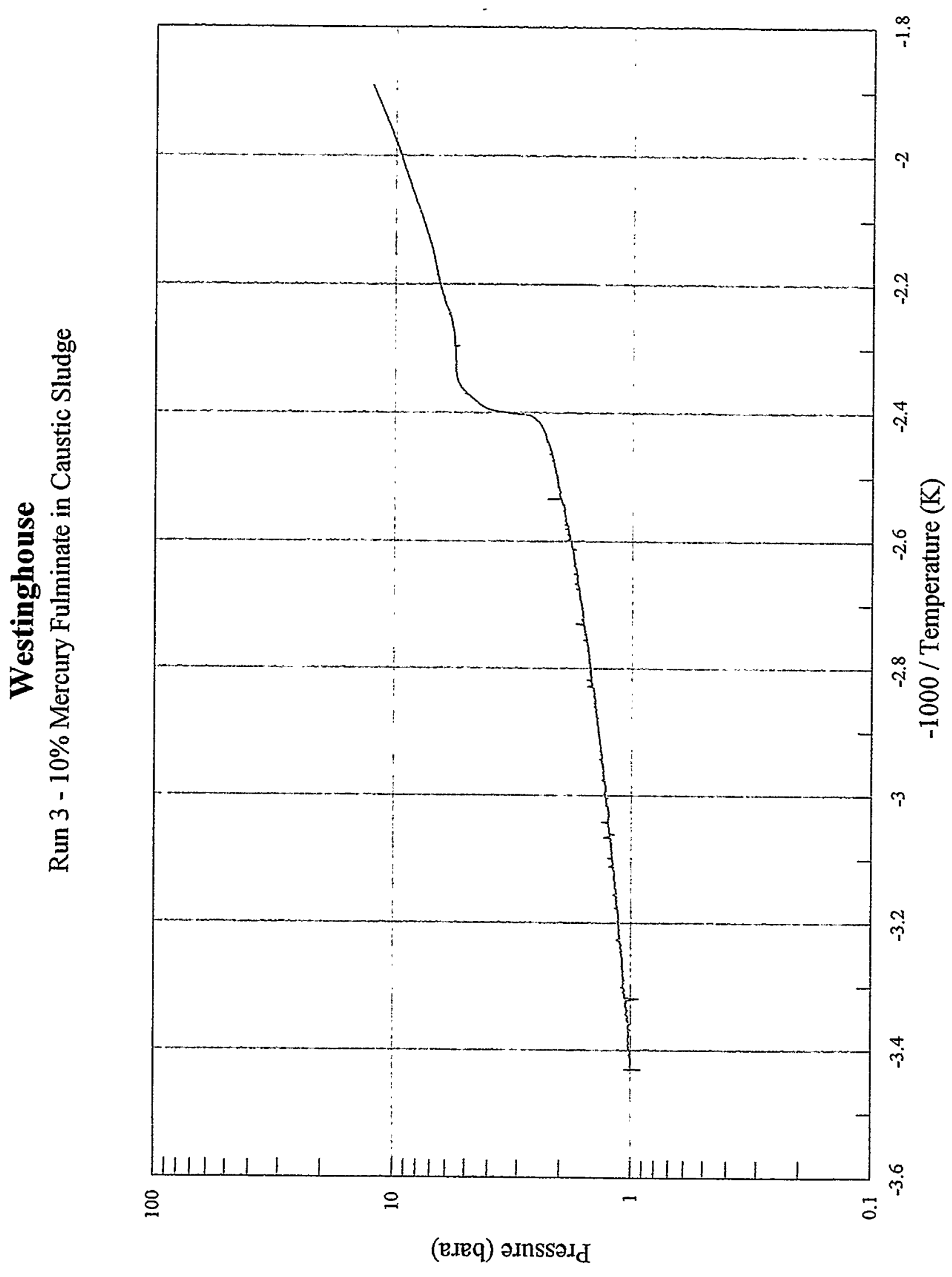

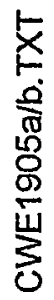




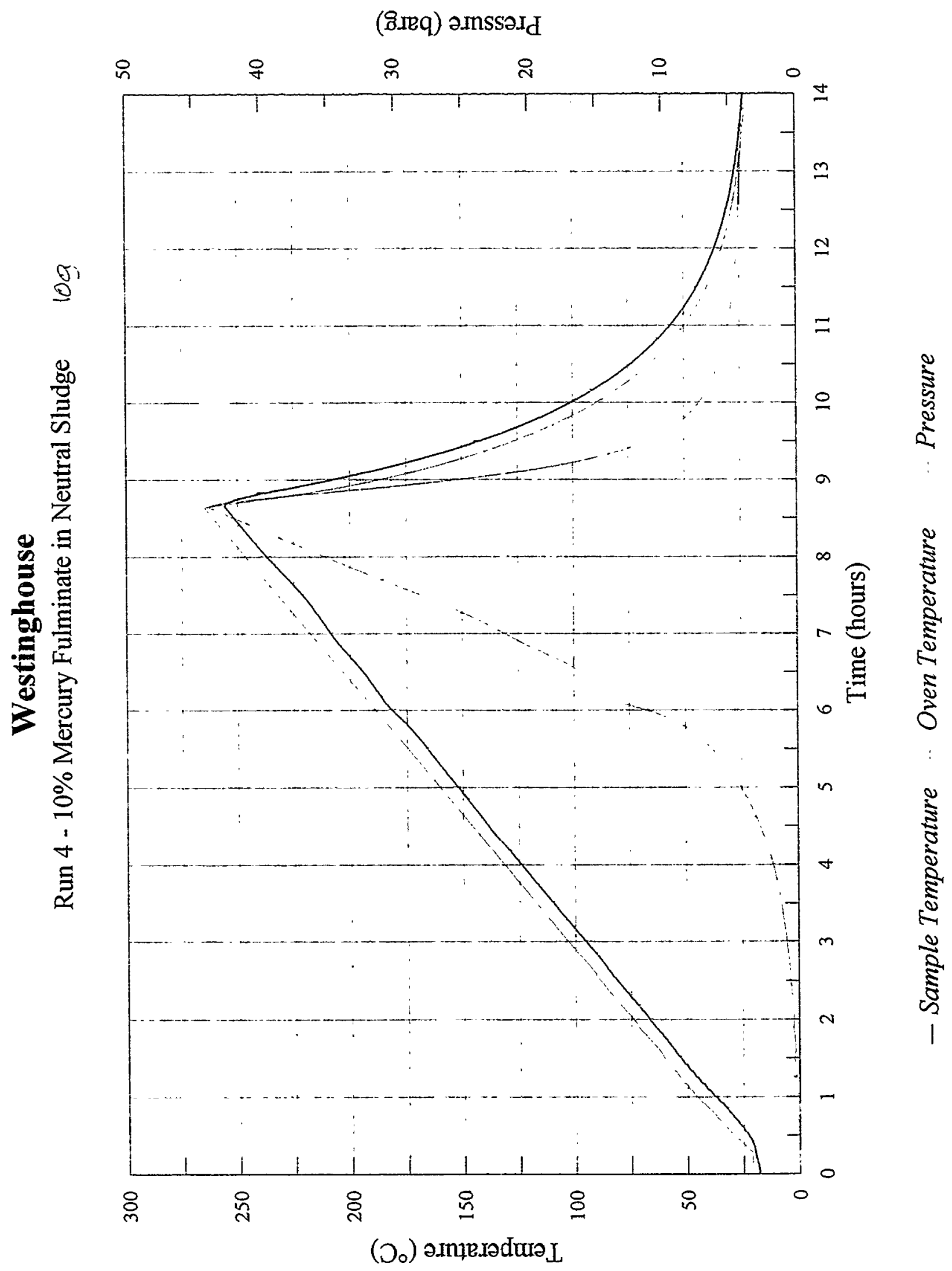


Westinghouse

Run 4 - 10\% Mercury Fulminate in Neutral Sludge

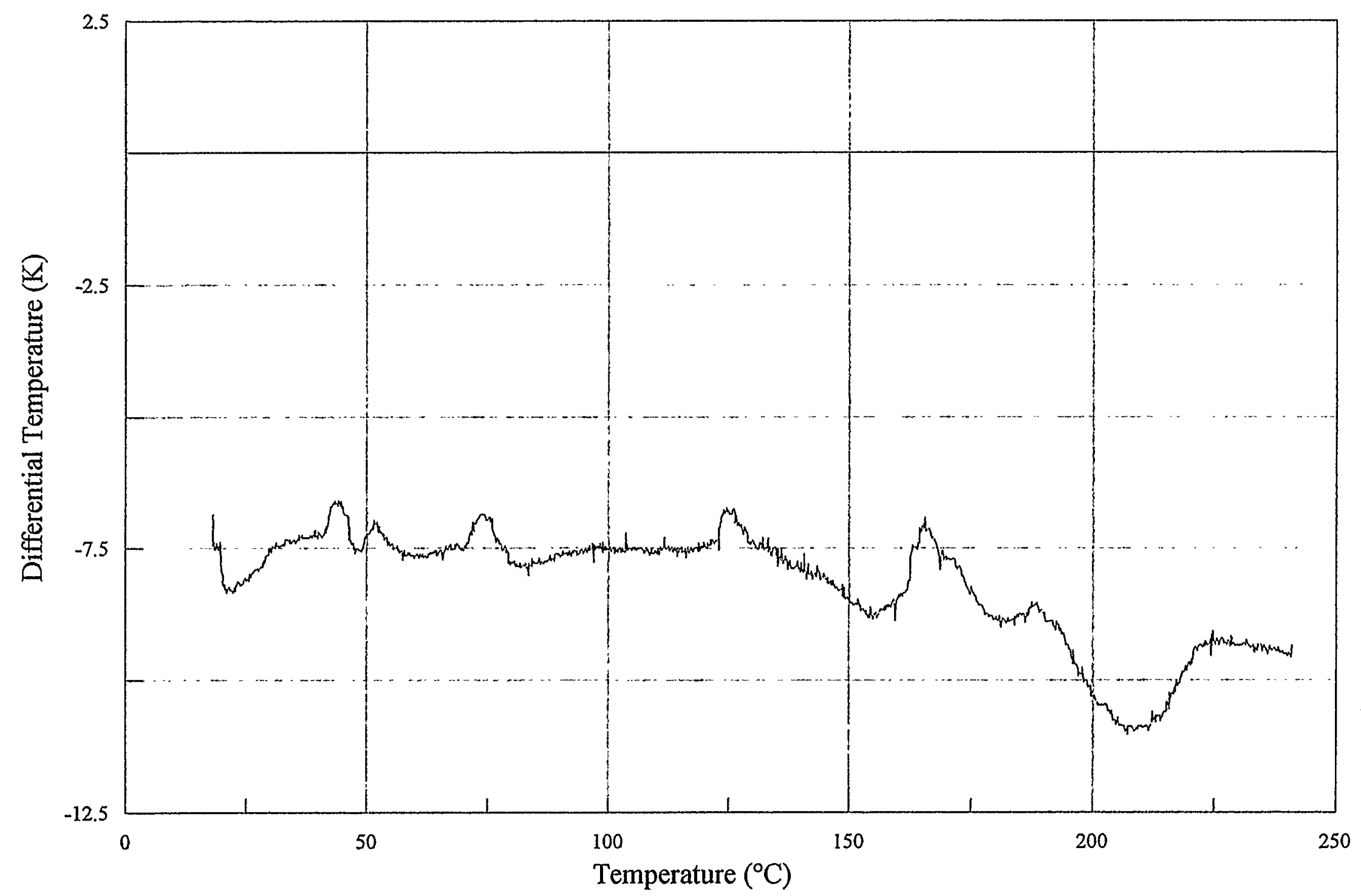

CWE1905c/d.TXT 


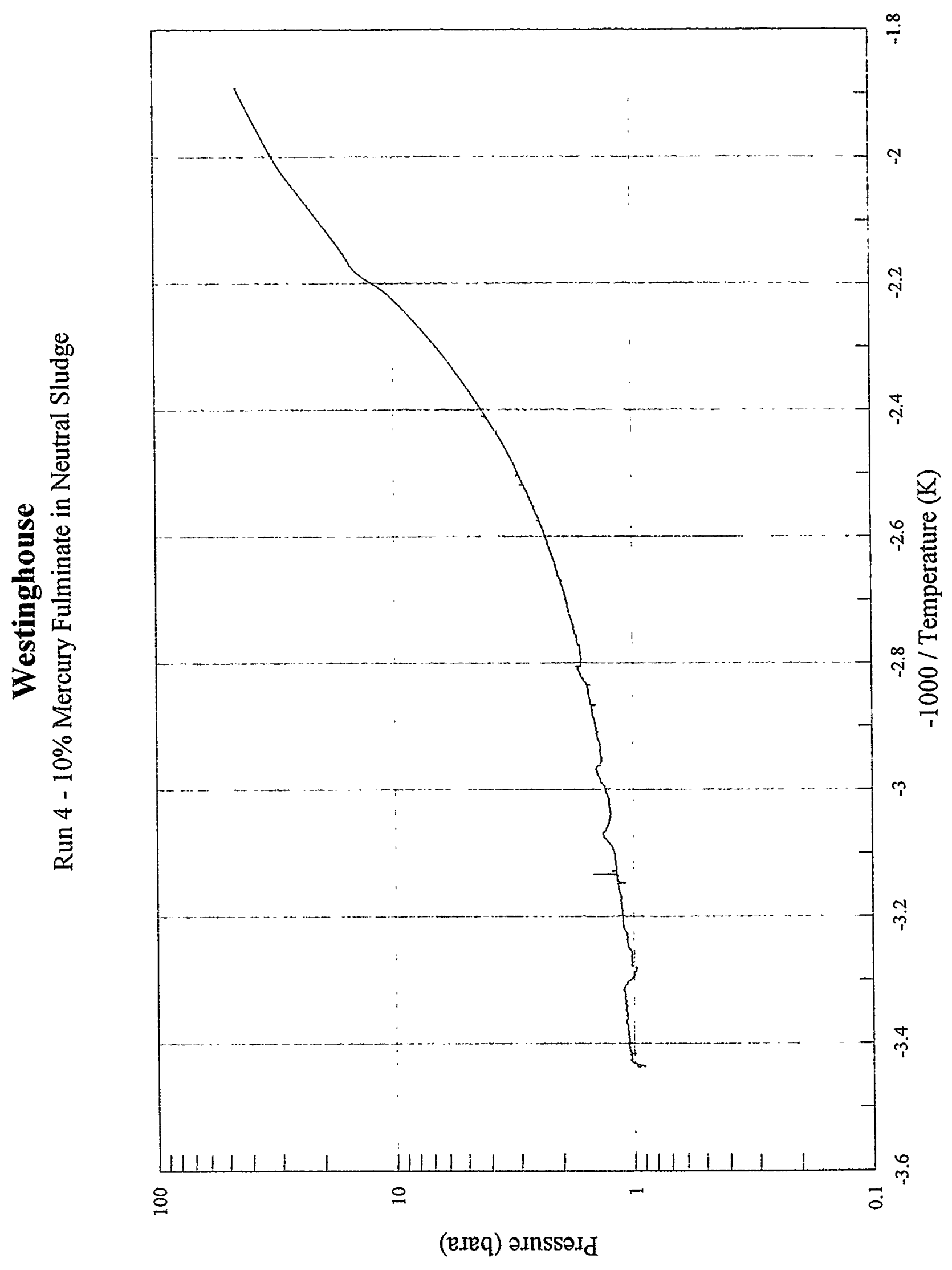




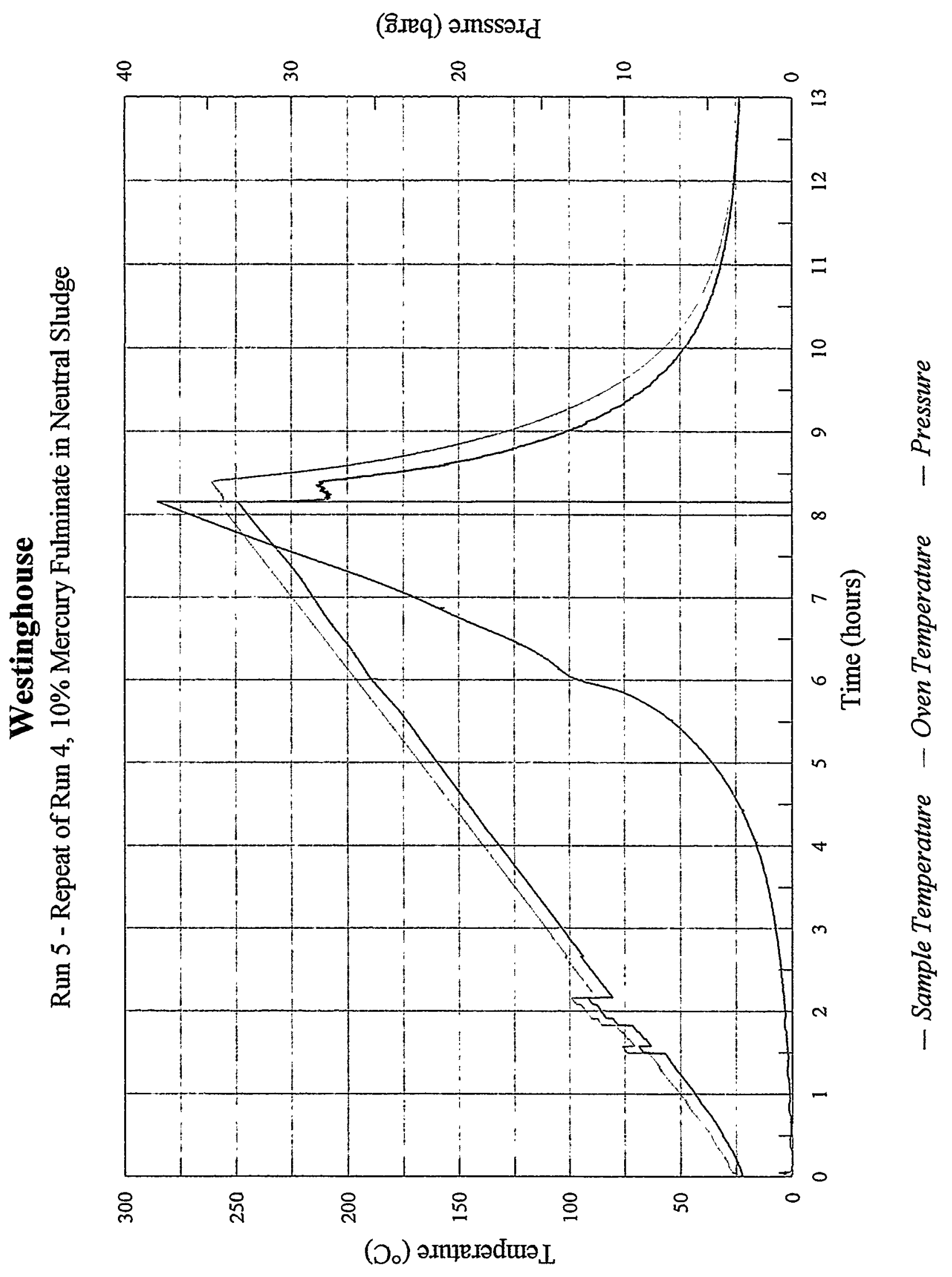

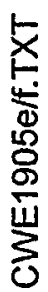




\section{Westinghouse}

Run 5 - Repeat of Run 4, 10\% Mercury Fulminate in Neutral Sludge

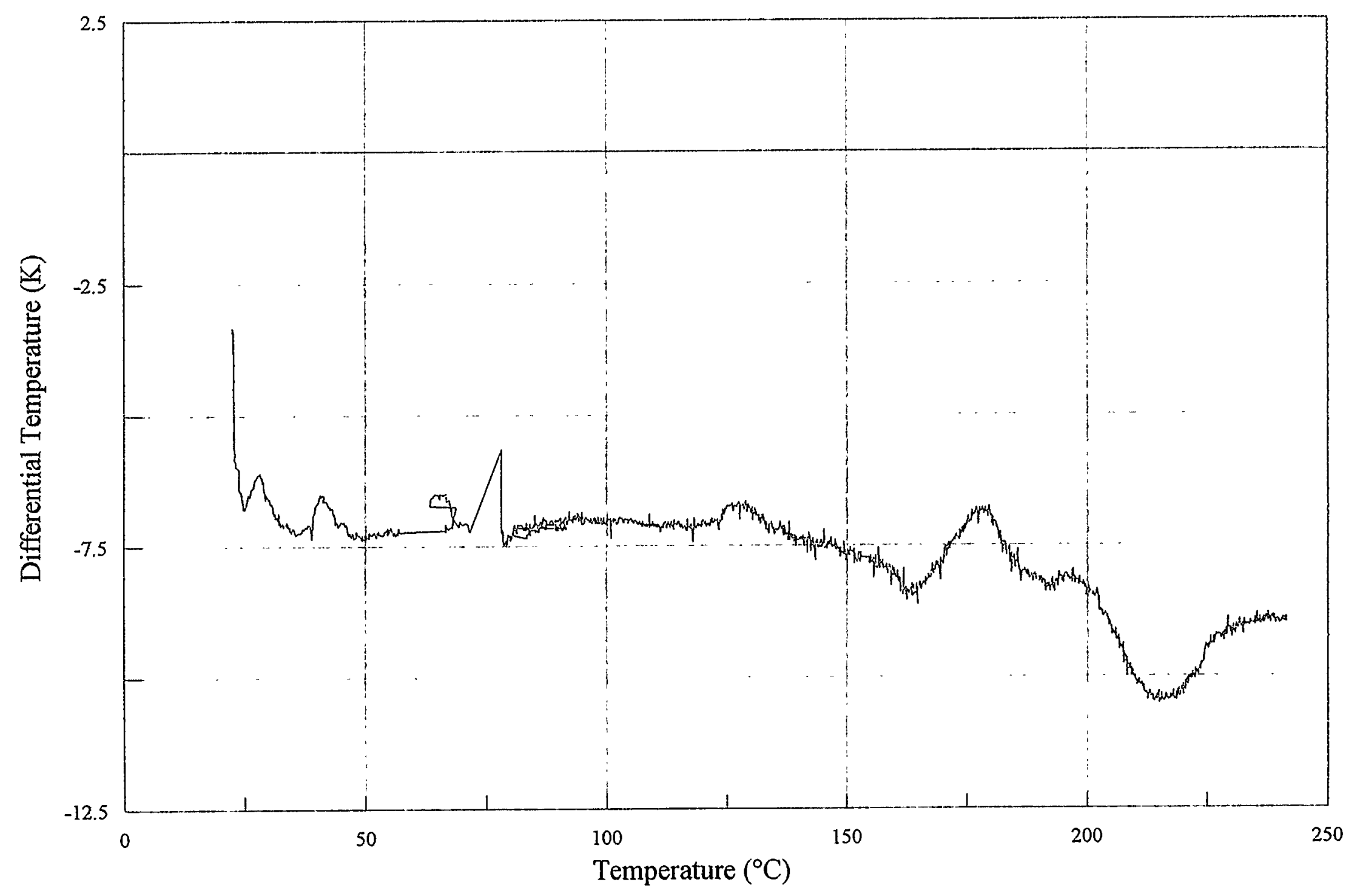

CWE1905e/f.TXT 


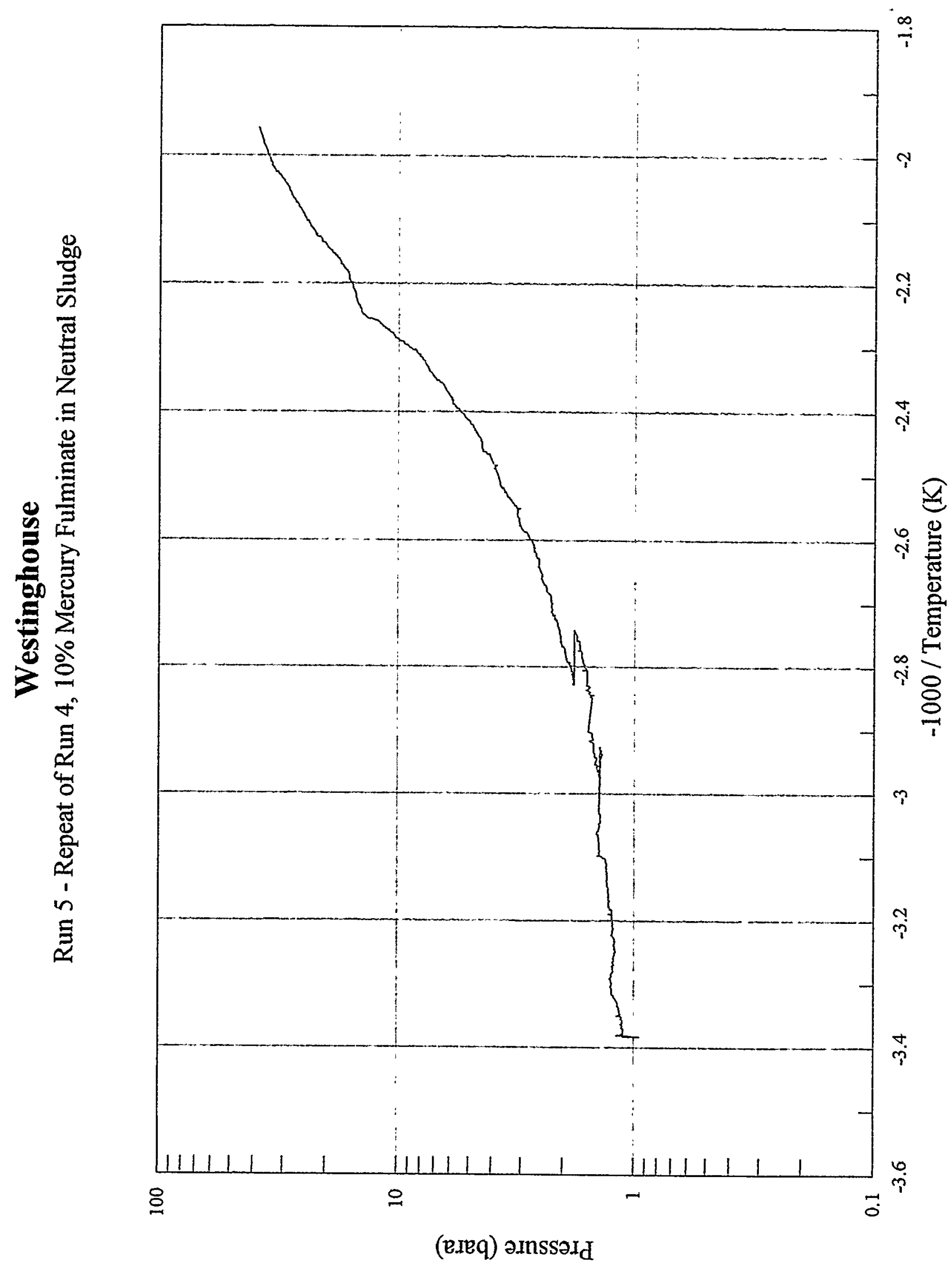


APPENDIX 6 


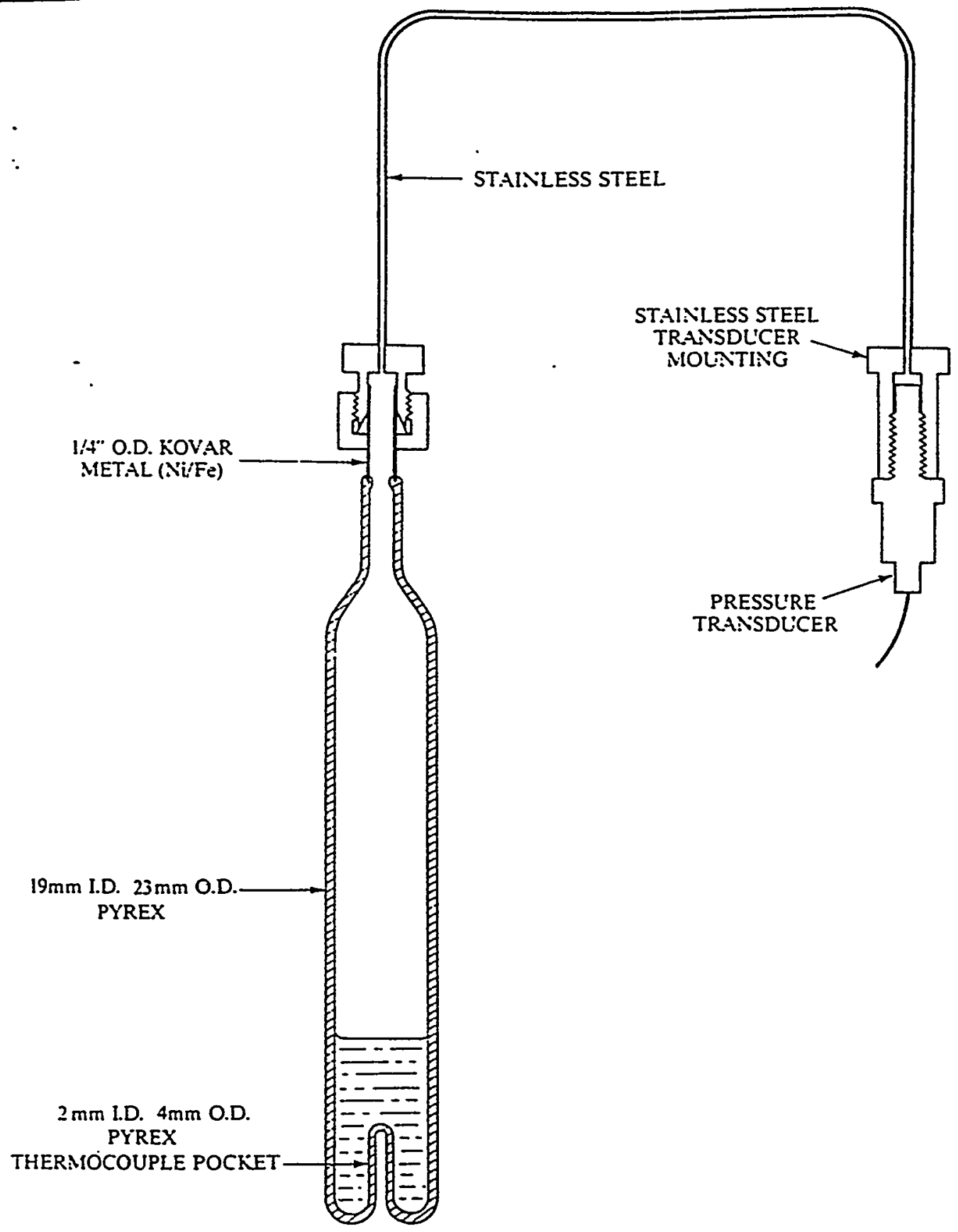


'BAM' Fallhammer Test Apparatus

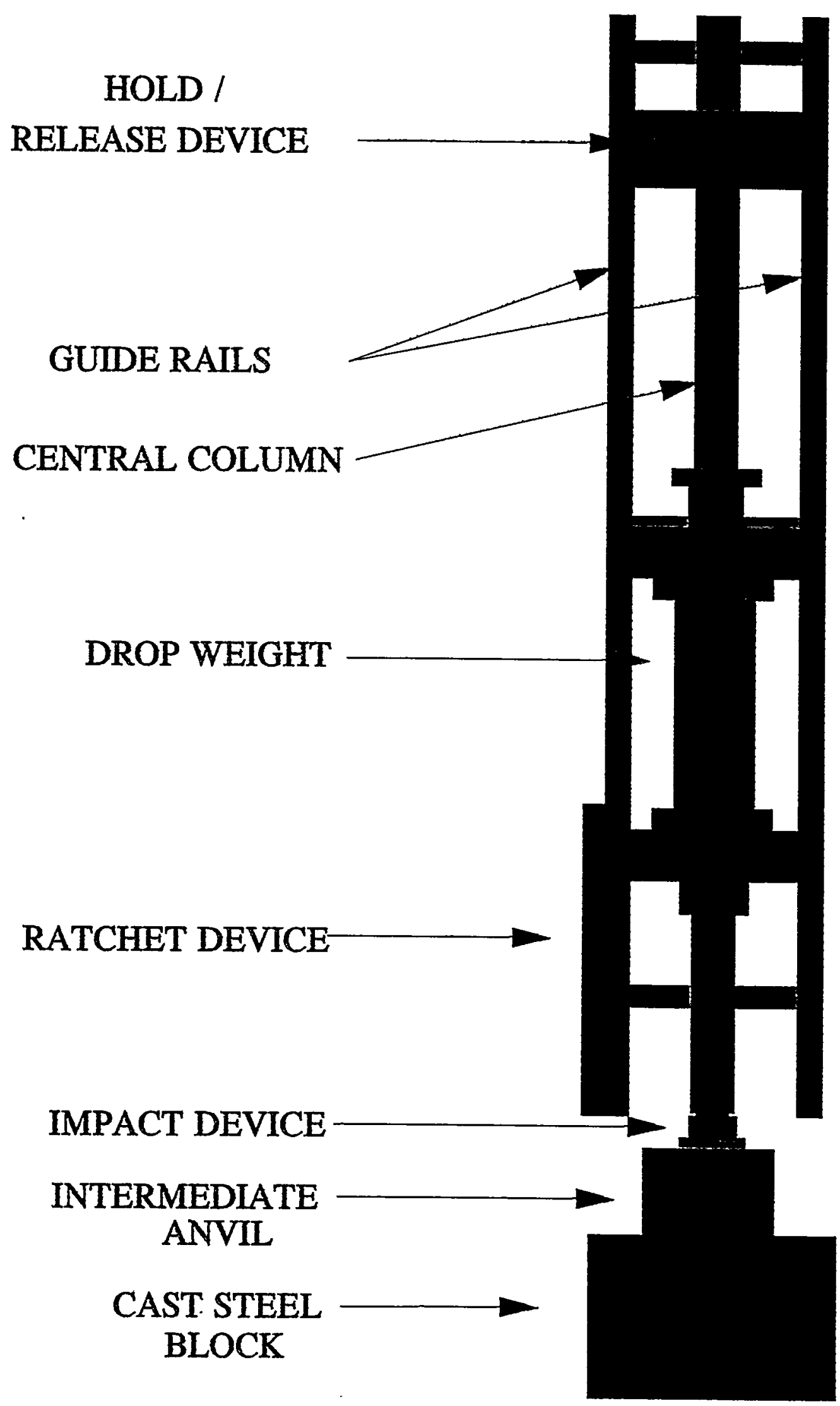




\section{APPENDIX 7}




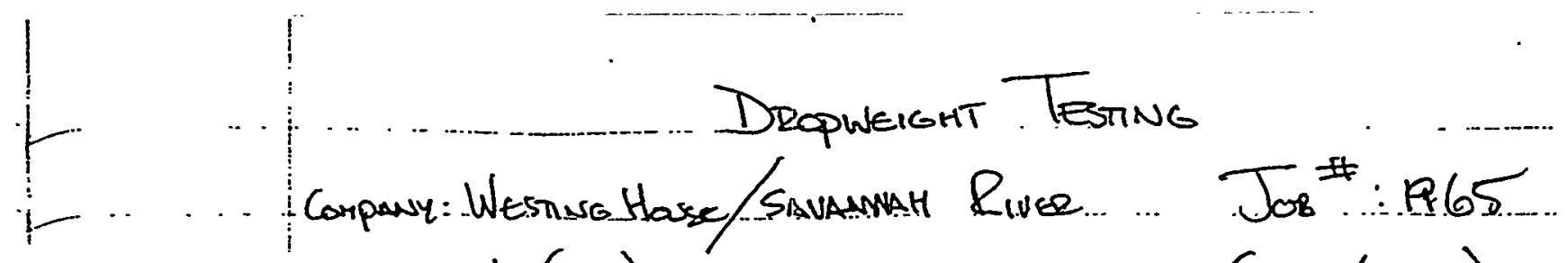

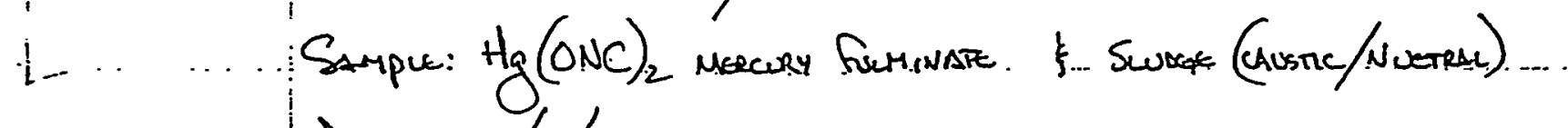

DATE: $3 / 3 / 49$

L

Supue Size: 30 mg -40 m.
Triac 1 - Pure Mecury Gurminite.

Book Value $x^{10.2 \mathrm{~cm}}$

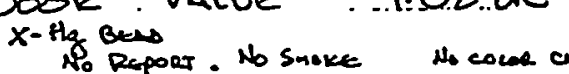

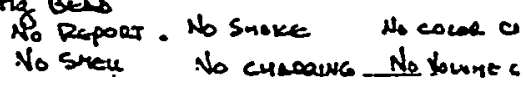

$-0.450 \mathrm{~g}$ 45.0.ing.

TEST. HEIGNT

$.0412 g$ 41:2ing ....1:2 $10 \mathrm{~cm} \quad 0$ O Sultert cosera

$.0400 \mathrm{~g} 400 \mathrm{~g}$

1.3

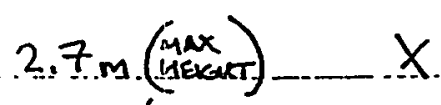
- Sifere

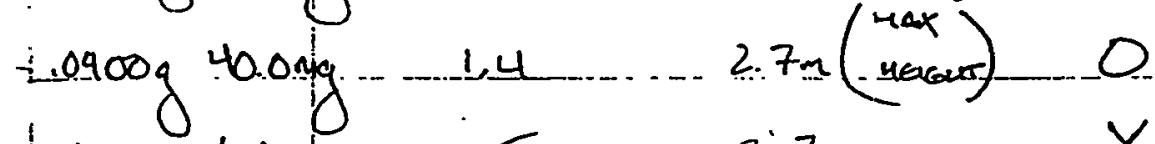

$+10100 \mathrm{~g} .10 .0 \mathrm{mg}$ $1.5 \quad 2.7 \mathrm{~m}$ croed

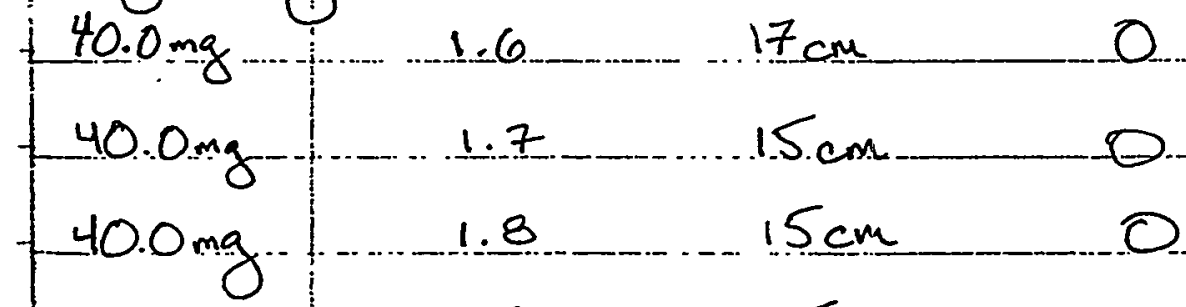
$\cos \theta$

$$
\text { . ..... . }
$$




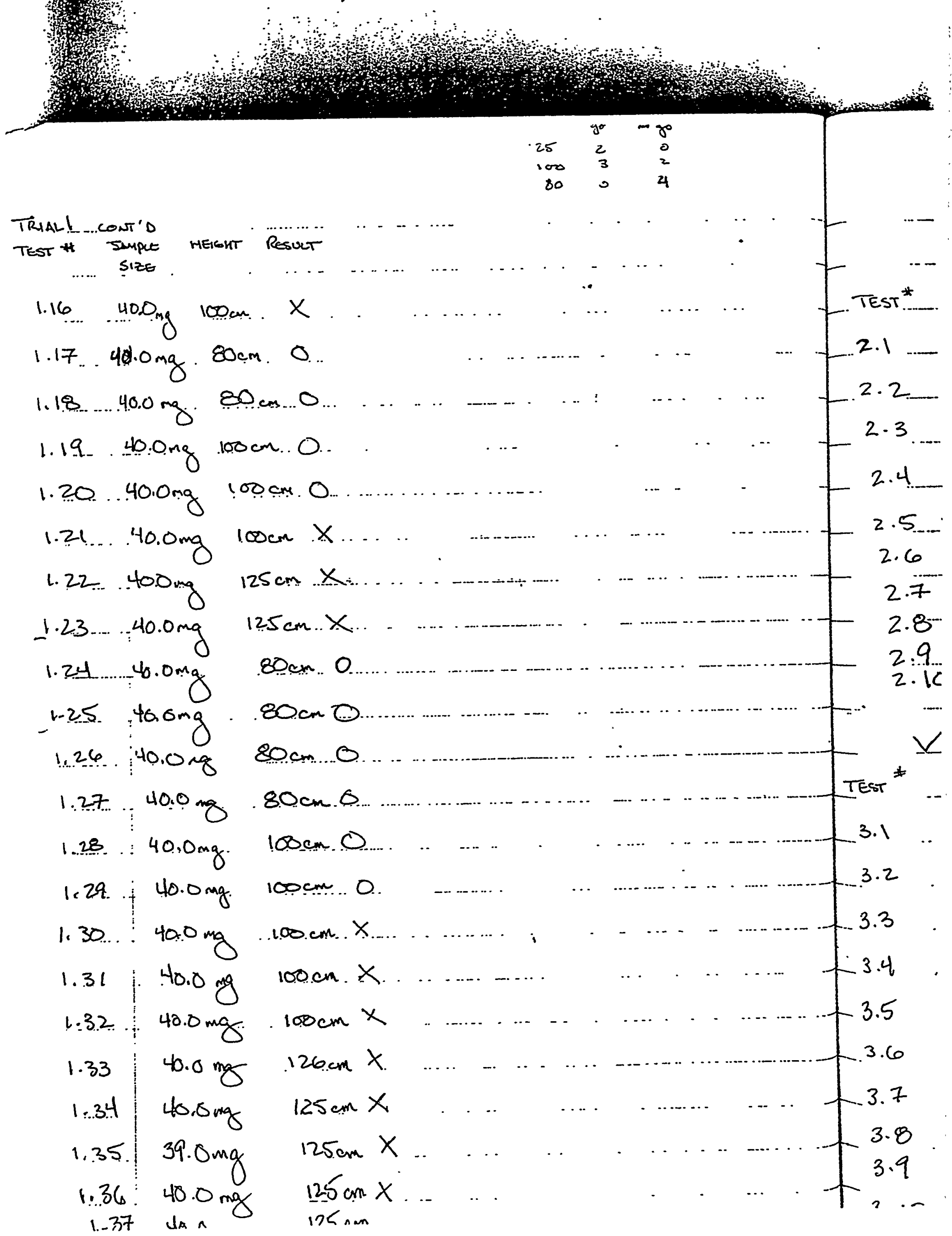


- Trial 2 10Z funwate Nu Nura SMPpue HEIGUT ReSUTT

$\therefore$ TEST*

- size

$$
\begin{aligned}
& \text { 2.1... -41.0mg } 2.7 \text { m(nax) } \\
& 2.2 \quad 40.0 \mathrm{mg} 2.7 \mathrm{~m} \ldots 0
\end{aligned}
$$

$-40.0 \mathrm{mg} 2.7 \mathrm{~m} 0$ $40.0 \mathrm{mg} 2.7 \mathrm{~m} \quad 0$ $40.0 \mathrm{mg} 2.7 \mathrm{~m} .0$ $40.0 \mathrm{mg} 2.7 \mathrm{~m} 0$

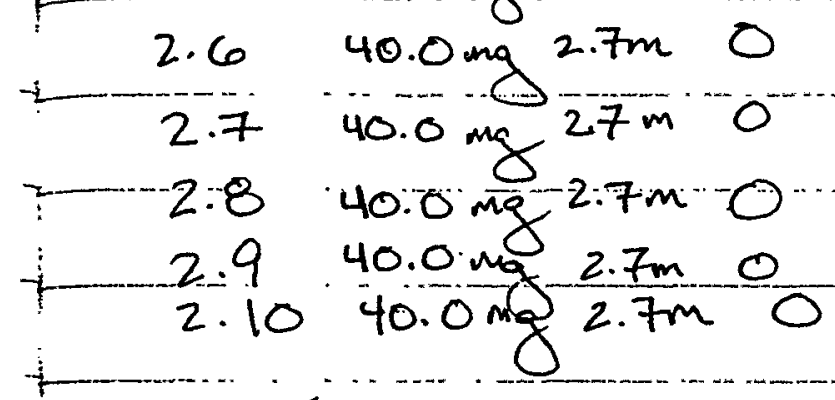
Trrial 3 heilt $10 \%$ fulminate in Caustic

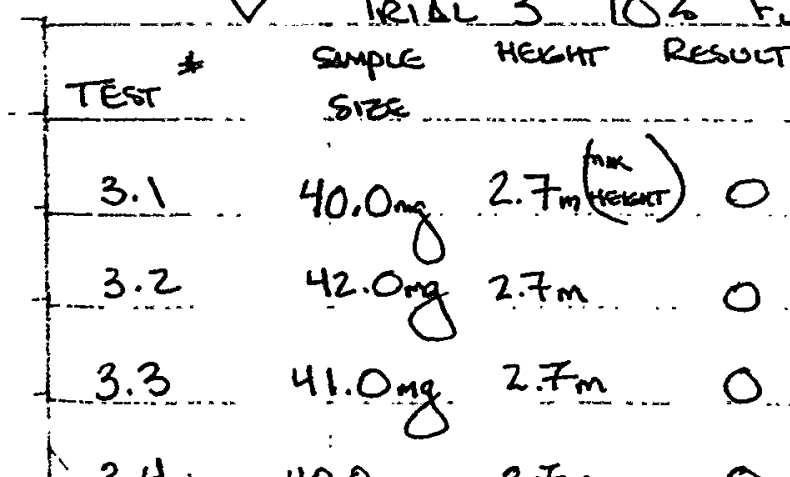

f.3.4... $40.0 \mathrm{ng} 2.7 \mathrm{~m} .0 \ldots \ldots$

+3.5 40.0mg $2.7 \mathrm{~m}$. 0 ..

$+3.6 .40 .0 \mathrm{mg} 2.7 \mathrm{~m} .0$

$\begin{array}{rrrr}3.7 & 40.0 \mathrm{mg} & 2.7 \mathrm{~m} & 0 \\ 3.8 & 41.0 \mathrm{mg} & 2.7 \mathrm{~m} & 0 \\ 3.9 & 40.0 \mathrm{mg} & 2.7 \mathrm{~m} & 0\end{array}$

$3.10 \quad 40.0 \mathrm{mg} 2.7 \mathrm{mo}$ 


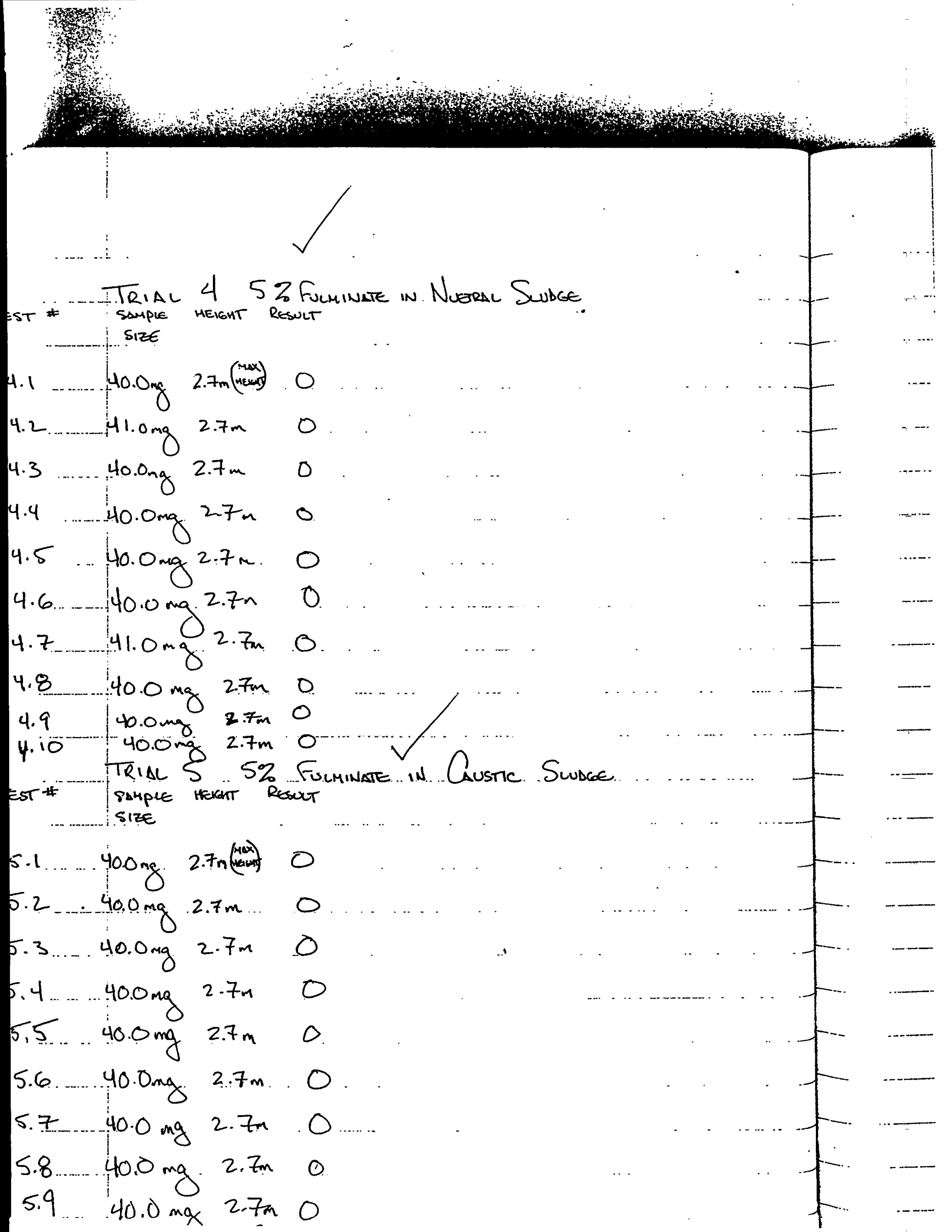




\section{DISTRIBUTION}

S. M. Aleman, 703-H

M. J. Barnes, 773-A

T. E. Britt, 703-H

N. R. Davis, 703-H

V. G. Dickert, 703-H

L. O. Dworjanyn, 735-11A

S. D. Fink, 773-A

F. F. Fondeur, 773-A

E. A. Freed, 742-5G

D. C. Hannah, 703-46A

M. S. Hay, 773-A

D. T. Hobbs, 773-A

G. J. Hutchens, 703-H

P. R. Jackson, 703-46A

M. D. Johnson, 703-H

B. L. Lewis, 703-H

T. J. Lex, 703-H

P. E. Lowe, $773-41 \mathrm{~A}$

T. M. Monahan, 703-H

J. P. Morin, 703-H

T. A. Nance, 723-A

L. M. Nelson, 773-43A

L. M. Papouchado, 773-A

R. H. Ross, 703-H

M. G. Schwenker, 703-46A

M. S. Shurrab, 703-H

R. F. Swingle, 773-A

W. I. Tamosaitis, 773-A

T. C. Temple, 703-H

W. B. Van-Pelt, 679-T

D. D. Walker, 773-A

W. R. Wilmarth, 773-42A

S. R. Wilson, 704-28S

G. T. Wright, 703-A

TIM, 703-43A

WPTS Files, c/o C. C. Canada, 773-A 